\title{
Introductory notes to factsheets Chapter 14
}

\author{
Alain Roques', David Lees \\ I Institut National de la Recherche Agronomique (INRA), UR 0633, Station de Zoologie Forestière, $2163 \mathrm{Av}$. \\ Pomme de Pin, 45075 Orléans, France 2 INRA UR633 Zoologie Forestière, 2163 Av. Pomme de pin, 45075 \\ Orléans, France
}

Corresponding author: Alain Roques (alain.roques@orleans.inra.fr)

Academic editor: Alain Roques | Received 14 May 2010 | Accepted 26 May 2010 | Published 6 July 2010

Citation: Roques A, Lees D (Eds) (2010) Factsheets for 80 representative alien species. Chapter 14. In: Roques A et al. (Eds) Arthropod invasions in Europe. BioRisk 4(2): 855-1021. doi: 10.3897/biorisk.4.69

Among the 1590 terrestrial arthropod species alien to Europe identified in this book, 78 were selected to produce specific factsheets in order to provide more information on their biology, distribution and impact. We included two more species which are alien in Europe, the horse-chestnut leaf miner (Cameraria obridella) and the African cotton leafworm (Spodoptera littoralis) because of their importance.

These 80 species are perhaps not the most important alien invaders, but they are rather representatives of the main taxonomic groups of alien terrestrial arthropods. They were selected so as to represent different pathways of introduction and diverse impacts on ecosystems, economic activities and human and animal health. These species include two myriapods, one spider, one mite, 18 coleopterans, seven dipterans, 23 hemipterans, 10 hymenopterans, one termite, 14 lepidopterans, and three thrips. Each factsheet includes information on the following aspects:

Description and biological cycle: $A$ brief description of adults and immature stages is given, whenever possible illustrated by a photograph, to help the reader identify the species. Further information details the general characteristics of the biological cycle in the invaded area, especially the species' potential to reproduce and the hosts it has colonized.

Native habitat: The factsheet includes the habitat type where the species is found in its native range. In order to make habitat types comparable among taxa, we adopted the classification of the European Nature Information System (EUNIS) database

Copyright A. Roques, D. Lees This is an open access article distributed under the terms of the Creative Commons Attribution License, which permits unrestricted use, distribution, and reproduction in any medium, provided the original author and source are credited. 
(http://eunis.eea.europa.eu). The habitat type codes are detailed in Appendix II. When information was available, we included specific habitat requirements which may help understand the potential of the species to establish and spread in Europe.

Habitat occupied in invaded range: The different habitats colonized by the alien species are described as for native habitats.

Native range: The native distribution of the species is described. For some species, there is very precise information available, but for others, only brief details of a region or even continent can be given.

Introduced range: The date of the first record in Europe and the location of this record is given, as well as details of the process of dispersion in the continent when available. A distribution map is supplied for all species. For most of them, presence/ absence data have been obtained only at country level, but for a few species, more detailed maps are given to show the distribution at regional scale. However, the missing occurrence of species from some countries does not always mean that these countries are not colonized, but may rather result from a lack of data for the country concerned. The map also indicates eradication records where relevant.

Pathways: We included information on the routes of introduction to Europe, and the potential of the species to disperse within the continent once it has established.

Impact and management: This section details the importance of the species' impacts in the colonized habitats. Both ecological and economical impacts are detailed when known. Practical advice where known is given regarding mechanical, chemical and biological control methods.

Selected references: Three of the most relevant references to the history of the species' introduction and spread in Europe are given. 


\section{List of the species}

1. Lamyctes emarginatus $\mathbf{8 6 2}$

2. Oxidus gracilis $\quad \mathbf{8 6 4}$

864 42. Leptoglossus occidentalis $\mathbf{9 4 4}$

3. Mermessus trilobatus $\quad \mathbf{8 6 6}$

43. Aspidiotus nerii $\quad \mathbf{9 4 6}$

4. Varroa destructor

868 44. Diaspidiotus perniciosus $\quad \mathbf{9 4 8}$

5. Agrilus planipennis

870

6. Anoplophora chinensis

45. Pseudaulacaspis pentagona

950

7. Anoplophora glabripennis

872

46. Metcalfa pruinosa

952

8. Diabrotica virgifera

874

9. Epitrix hirtipennis

876

47. Nysius huttoni

954

878

48. Stictocephala bisonia

956

10. Leptinotarsa decemlineata

49. Halyomorpha halys

958

880

11. Harmonia axyridis

882

12. Gonipterus scutellatus

13. Rhopalapion longirostre

884

50. Viteus vitifoliae

960

14. Trogoderma granarium

886

51. Corythucha arcuata

962

52. Corythucha ciliata

964

888

53. Cales noacki

966

15. Diocalandra frumenti

890

54. Lysiphlebus testaceipes

968

16. Rhynchophorus ferrugineus

892

17. Megaplatypus mutatus

55. Dryocosmus kuriphilus

970

894

56. Ophelimus maskelli

972

18. Gnathotrichus materiarius

57. Lasius neglectus

974

896

58. Linepithema humile $\mathbf{9 7 6}$

19. Phloeosinus rudis

898

59. Nematus tibialis

978

20. Xylosandrus crassiusculus

900

21. Xylosandrus germanus

902

22. Tribolium confusum

904

23. Liriomyza huidobrensis

24. Liriomyza trifolii

906

60. Megastigmus spermotrophus

980

25. Dasineura gleditchiae

908

910

61. Sceliphron curvatum, S. caementarium and $S$. deforme

982

62. Vespa velutina

984

63. Reticulitermes flavipes $\mathbf{9 8 6}$

26. Obolodiplosis robiniae

64. Hyphantria cunea

988

912

65. Paysandisia archon

990

914

66. Diplopseustis perieresalis

992

28. Ceratitis capitata

916

29. Rhagoletis completa

67. Phthorimaea operculella

994

918

30. Adelges (Dreyfusia) nordmannianae

68. Cameraria ohridella

996

920

69. Parectopa robiniella

998

31. Bemisia tabaci

922

70. Phyllonorycter issikii

1000

32. Trialeurodes vaporarium

924

71. Phyllonorycter platani

1002

33. Aphis gossypi

926

72. Phyllonorycter robiniella

1004

34. Cinara curvipes

928

73. Cacyreus marshalli

1006

35. Macrosiphum euphorbiae

930

74. Spodoptera littoralis

1008

36. Myzocallis walshii

932

75. Epichoristodes acerbella

1010

37. Myzus persicae

934

76. Grapholita molesta

1012

38. Prociphilus fraxiniifolii

936

77. Argyresthia thuiella

1014

39. Toxoptera citricidus

938

78. Frankliniella occidentalis

1016

40. Scaphoideus titanus

940

79. Pseudodendrothrips mori

1018

41. Pulvinaria regalis

942

80. Thrips palmi

1020 


\section{Adresses of factsheets authors}

\section{Sylvie Augustin (\#68)}

INRA UR633 Zoologie Forestiere, 2163 Av. Pomme de Pin, 45075 Orléans, France; (sylvie.augustin@orleans.inra.fr)

\section{Yuri Baranchikov (\#5)}

Department of Forest Zoology, V.N.Sukachev Institute of Forest, Siberian Branch, Russian Academy of Science, 50 Akademgorodok, Krasnoyarsk 660036, Russia (baranchikov_yuri@yahoo.com)

\section{Ejup Çota (\#24, \#36, \#39)}

Plant Protection Department, Faculty of Agriculture and Environment, Agriculture University of Tirana, Albania; (ejupcota@gmail.com)

\section{Jurate De Prins (\#66, \#73)}

Entomology Section, Royal Museum for Central Africa, Leuvensesteenweg 13, B-3080 Tervuren, Belgium; (jurate.de.prins@africamuseum.be)

\section{Willy De Prins (\#66, \#73)}

Entomology Section, Royal Museum for Central Africa, Leuvensesteenweg 13, B-3080 Tervuren, Belgium; (willy.deprins@gmail.com)

\section{Massimo Faccoli (\#17, \#18, \# 20, \#21)}

Universita di Padova, Department of Environmental Agronomy and Crop Sciences, Agripolis, Viale dell'Università 16, 35020 Legnaro (PD), Italy; (massimo.faccoli@unipd.it)

Milka M. Glavendekić (\#25, \#46, \#55, \#59)

University of Belgrade, Faculty of Forestry, Kneza Viseslava 1, 11030 Belgrade, Serbia; (milka.glavendekic@nadlanu.com)

\section{Stanislav Gomboc (\#75)}

Siskovo naselje 19, SI-4000 Kranj, Slovenia; (stane.gomboc@gov.si)

Marc Kenis (\#29, \#41, \#44, \#50, \#51, \#63)

CABI Europe-Switzerland, 1, Rue des Grillons, CH-2800, Delémont, Switzerland; (m.kenis@ cabi.org)

\section{Zoltán Korsós (\#2)}

Zoological Department, Hungarian Natural History Museum H-1088 Budapest, Hungary (korsos@zoo.zoo.nhmus.hu) 
Ferenc Lakatos (\#13, \#14, \#22, \#43, \#64, \#77)

University of West-Hungary, Institute of Sylviculture and Forest Protection, Bajcsy-Zs. u. 4., H-9400 Sopron, Hungary; (flakatos@emk.nyme.hu)

\section{Zdeněk Laštůvka (\#76)}

Department of Zoology, Fisheries, Hydrobiology and Apidology, Faculty of Agronomy, Mendel University in Brno, Zemédèlská 1,CZ-613 00 Brno, Czech Republic; (last@mendelu.cz)

\section{Yves Le Conte (\#4)}

Institut National de la Recherche Agronomique (INRA), UMR0406 AE Abeilles et Environnement, Domaine Saint-Paul - Site Agroparc 84914 Avignon, France; (yves.leconte@avignon.inra.fr)

David Lees (Introductory notes, \#65, \#69, \#70, \#71, \#72)

INRA UR633 Zoologie Forestiere, 2163 Av. Pomme de Pin, 45075 Orléans, France; (david.lees@ orleans.inra.fr)

Carlos Lopez-Vaamonde (\#10, \#65, \#74)

INRA UR633 Zoologie Forestiere, 2163 Av. Pomme de Pin, 45075 Orléans, France; (carlos.lopezvaamonde@orleans.inra.fr)

\section{Ljubodrag Mihajlović (\#25)}

University of Belgrade, Faculty of Forestry, Kneza Viseslava 1, 11030 Belgrade, Serbia; (mljuba@ EUnet.rs)

\section{Leen Moraal (\#19)}

Alterra, Wageningen UR, Centre Ecosystems, PO Box 47, NL-6700 AA Wageningen, The Netherlands; (Leen.Moraal@wur.nl)

\section{Franck Muller (\#62)}

Museum National d'Histoire Naturelle Entomologie CP50, 45 rue Buffon, 75005 Paris, France

\section{Maria Navajas (\#4)}

Institut National de la Recherche Agronomique, UMR CBGP (INRA/IRD/Cirad/Montpellier SupAgro), Campus International de Baillarguet, CS 30016, F-34988, France; (navajas@supagro.inra.fr)

\section{Olivera Petrović-Obradović (\#34, \#35, \#37, \#38)}

University of Belgrade, Faculty of Agriculture, Nemanjina 6, SER-11000, Belgrade, Serbia; (petrovic@agrif.bg.ac.rs) 
Wolfgang Rabitsch (\#8, \#15, \#16, \#40, \#42, \#47, \#48, \#49, \#51, \#52, \#57, \#58)

Environment Agency Austria, Dept. Biodiversity \& Nature Conservation, Spittelauer Lände 5, 1090 Vienna, Austria; (wolfgang.rabitsch@umweltbundesamt.at)

Jean-Yves Rasplus (\#53, \#54, \#56, \#61)

Institut National de la Recherche Argonomique, UMR Centre de Biologie et de Gestion des Populations, CBGP, (INRA/IRD/CIRAD/Montpellier SupAgro), Campus international de Baillarguet, CS 30016, 34988 Montferrier-sur Lez, France; (rasplus@supagro.inra.fr)

\section{Hans Peter Ravn (\#30)}

Forest \& Landscape Denmark, University of Copenhagen, Hoersholm Kongevej 11, DK-2970 Hoersholm, Denmark; (hpr@life.ku.dk)

\section{Philippe Reynaud (\#79, \#80)}

Laboratoire national de la protection des végétaux, Station d'Angers, 7 rue Jean Dixméras, 49044 Angers Cedex 01, France; (philippe.reynaud@agriculture.gouv.fr)

\section{Quentin Rome (\#62)}

Museum National d'Histoire Naturelle Entomologie CP50, 45 rue Buffon, 75005 Paris, France (vespa.velutina@gmail.com)

Alain Roques (Introductory notes, \#23, \#27, \#28, \#31, \# 32, \#33, \#55, \#60, \#78)

Institut National de la Recherche Agronomique (INRA), UR 0633, Station de Zoologie Forestiere, 2163 Av. Pomme de Pin, 45075 Orléans, France; (alain.roques@orleans.inra.fr)

David B. Roy (\#11)

Centre for Ecology \& Hydrology, Crowmarsh Gifford, Oxfordshire, OX10 8BB, United Kindgom (dbr@ceh.ac.uk)

\section{Helen Roy (\#11)}

NERC Centre for Ecology \& Hydrology, Biological Records Centre, Crowmarsh Gifford, Oxfordshire, OX10 8BB, United Kindgom (hele@ceh.ac.uk)

Daniel Sauvard (\#6, \#7, \#12)

INRA UR633 Zoologie Forestiere, 2163 Av. Pomme de Pin, 45075 Orléans, France; (daniel.sauvard@orleans.inra.fr)

\section{Martin H Schmidt-Entling (\#3)}

University of Bern, Institute of Ecology and Evolution, Community Ecology, CH-3012 Switzerland (martin.schmidt@zos.unibe.ch)

\section{Marcela Skuhravá (\#26)}

Bitovská 1227/9, 14000 Praha 4, Czech Republic; (skuhrava@quick.cz) 
Pavel Stoev (\#2)

National Museum of Natural History, Tsar Osvoboditel Blvd. 1, 1000 Sofi a, Bulgaria (pavel.e.stoev@gmail.com)

Jean-Claude Streito (\#52)

Laboratoire national de la protection des végétaux, CBGP Campus international de Baillarguet, CS 30016, FR-34988 Montferrier-sur-Lez cedex, France; (streito@supagro.inra.fr)

\section{Rumen Tomov (\#9)}

University of Forestry, 10 Kliment Ohridski blvd., 1756 Sofia, Bulgaria (rtomov@yahoo.com)

\section{Georgyi Trenchev (\#67)}

University of Forestry, 10 Kliment Ohridski blvd., 1756 Sofia, Bulgaria (k_trencheva@yahoo. com)

\section{Katia Trencheva $(\# 45, \# 67)$}

University of Forestry, 10 Kliment Ohridski blvd., 1756 Sofia, Bulgaria; (k_trencheva@yahoo. com)

Katalin Tuba (\#13, \#14, \#22, \#43)

University of West-Hungary, Institute of Silviculture and Forest Protection, Sopron, Bajcsy-Zs. u. 4. 9400,Hungary (tubak@emk.nyme.hu)

\section{Claire Villemant (\#62)}

Museum National d'Histoire Naturelle, UMR Origine, Structure et Evolution de la Biodiversite, OSEB, (MNHN/CNRS) CP50, 45 rue Buffon, 75005 Paris, France; (villeman@mnhn.fr)

\section{Marzio Zapparoli (\#1)}

Universita degli Studi della Tuscia, Dipartimento di Protezione delle Piante, via S. Camillo de Lellis s.n.c., I-01100Viterbo, Italy (zapparol@unitus.it) 


\section{1 - Lamyctes emarginatus (Newport, 1844) (Chilopoda, Henicopidae)}

\section{Marzio Zapparoli}

Description and biological cycle: Body length $6.0-10.5 \mathrm{~mm}$, shape slender, feebly fusiform, first tergite distinctly narrower than head and than tergite 3. Chestnut brown to dark brown, with leg tips and antennae yellow (Photo). One ocellus only at each side of the head. Antennae one-third to two-fifths of body length, with 25 segments. 15 pairs of legs, slender and without spines. Tibia of $1^{\text {st }}-12^{\text {th }}$ segment with a sharp projection on the anterior edge of its distal extremity. Reliable identification possible only after light microscope examination. L. emarginatus is a soil dwelling predator of small invertebrates, apparently hygrophilous and generally solitary. It is a pioneer of disturbed habitats (e.g. mine sites). This centipede develops through five anamorphic larval and five post-larval stadia. The species reproduces by thelytokous parthenogenesis* (producing only females) in most of its range. Bisexual populations are known in the Azores and Canary Islands, as well as in New Zealand, Tasmania and Hawaii.

Native habitat (EUNIS code): Often collected at banks of creeks and rivers, and under stones where there is moisture. Some records from grasslands (E). In its native range Lamyctes emarginatus also commonly colonizes disturbed urban and suburban habitats.

Habitat occupied in invaded range (EUNIS code): In Europe recorded in a wide range of habitats, from open or semi-open habitats (E); cultivated lands (I, X6, X7); city parks (X23); gardens (I1, I2); more or less intensively built-up areas of villages and cities (J1, J2, J4); waste dumps (J6); plant nurseries (I1); mine sites (J3); artificial banks of streams and lakes more or less temporary flooded (J5); also in natural or semi-natural habitats such as woodlands (G1, G3); heathlands (F4); riversides (F9) ; bogs (D) and coastal environments (B1) (British Isles, Faroe Isl., Northern Italy). Almost the same range of habitats is known for North America, New Zealand and Tasmania.

Native range: Australasian species (western and southern Australia).

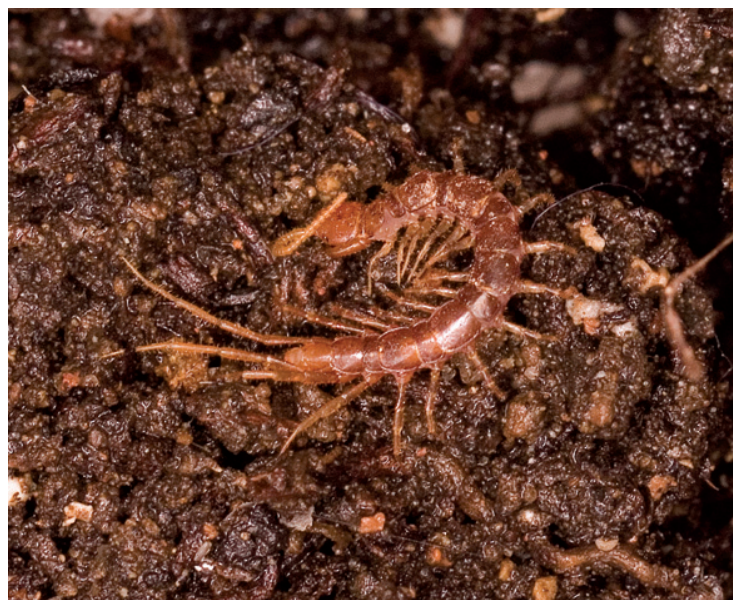




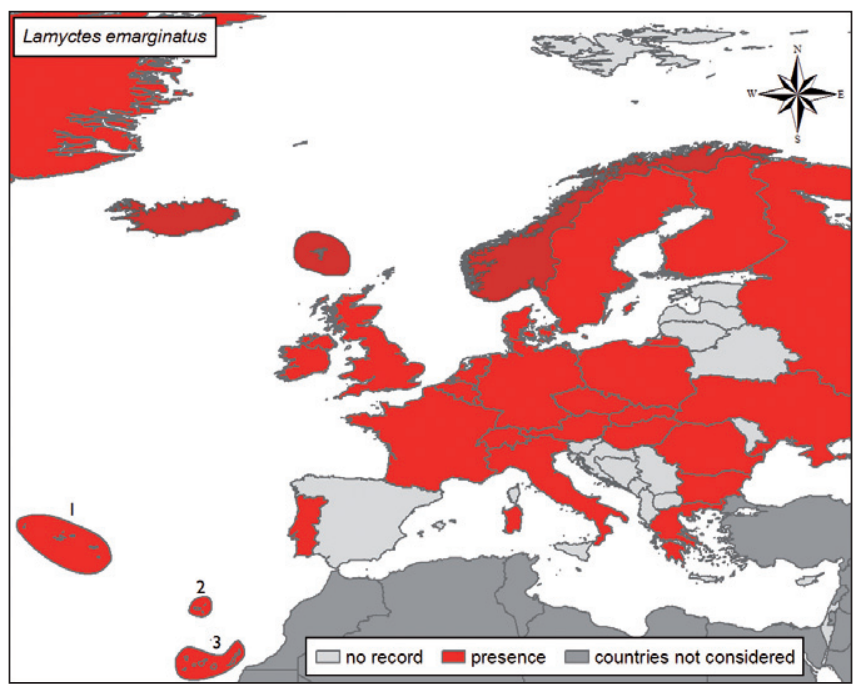

Introduced range: Present in almost all European countries and Atlantic islands (Mapnot recorded elsewhere probably due to lack of research), Southwestern Asia (Georgia, Iran, Turkey), Africa (Morocco, Ethiopia, Kenya, Tanzania, Somalia), North America (Canada, USA), Central America (Cuba, Guadeloupe), South America (Galapagos Islands, Brazil), Hawaii. Probably introduced also in Tasmania (proposed common name: Domestic Woodrunner), New Caledonia, New Zealand, Chatham Islands, Fiji and Kermadec Islands.

Described as a new species by G. Newport from New Zealand in 1844, it has been recorded in Europe for the first time in 1868 in Denmark (Øerne) under the name of Lamyctes fulvicornis Meinert, 1868. The species may have been introduced into Europe even earlier, e.g. immediately after the British colonization of the Australian continent ( $18^{\text {th }}$ century).

Pathways: Mode of introduction and spread of this species is unknown, but probably occurred/occurs by passive transfer in rootballs of transplanted plants in which soil this small species temporarily settles. Parthenogenesis can then help the successful establishment of viable populations. Local-scale dispersal is probably achieved actively.

Impact and management: Unknown, but effects on trophic chains are possible. This species is presently economically unimportant, thus monitoring, chemical or biological control are considered unnecessary.

\section{Selected references}

Andersson G (2006) Habitat preferences and seasonal distribution of developmental stadia in Lamyctes emarginatus (Newport, 1844) (L. fulvicornis Meinert, 1868) and comparisons with some Lithobius species (Chilopoda, Lithobiomorpha). Norwegian Journal of Entomology 53: 311-320.

Bocher J, Enghoff H (1984) A centipede in Groenland: Lamyctes fulvicornis Meinert, 1868 (Chilopoda, Lithobiomorpha, Henicopidae). Entomologiske Meddelelser 52: 49-50.

Zerm M (1997) Distribution and phenology of Lamyctes fulvicornis and other lithobiomorph centipedes in the floodplain of the Lower Oder Valley, Germany (Chilopoda, Henicopidae: Lithobiidae). Entomologica Scandinavica suppl. 51: 125-132. 


\section{2 - Oxidus gracilis (C.L. Koch, 1847) \\ (Diplopoda, Polydesmida, Paradoxosomatidae)}

\section{Pavel Stoev and Zoltán Korsós}

Description and biological cycle: Typical "flat-backed" millipede (Order Polydesmida), body length 16-21 mm (males), 17-23 mm (females). Dorsal surface smooth, chestnut to dark reddish or blackish brown, with lighter, pale yellowish paranota* ("lateral wings") (Photo). Ventral surface and legs, head and antennae also dark brown. Immature stages light amber to cream. Further taxonomic traits and good illustrations of gonopods can be found in Blower (1985).

Native habitat (EUNIS code): From grasslands (E1, E2, E3, E5, E7) to all kinds of woody habitats (G1, G2, G3, G4), miscellaneous inland habitats (e.g. H5), occasionally entering subterranean localities $(\mathrm{H} 1)$, common in agricultural areas and other places under different degrees of disturbance (I1-I2, J2, J3, J4, J6, X7, X10, X11, X13, X14, X15, X16, X22, X23).

Habitat occupied in invaded range: (EUNIS code): In Europe the'greenhouse millipede' has been recorded most often in hothouses (J100), city parks (X23) and gardens (I1, I2). The only alien millipede to have invaded some natural ecosystems and at least partially acclimatized in Europe. Earliest records in Europe are from the $19^{\text {th }}$ century from Hungary, Austria, Germany, and the Netherlands from greenhouses and cities. Koch's (1847) type locality 'Puloloz' may refer to a locality in former Czechoslovakia or in 'Ostindien'. In North Europe, it was found for the first time in Finland in 1900. In the British Isles, first recorded from Edinburgh (1898) and Kew Gardens.

Native range: East or Southeast Asia. Two other congeners (O. avia and O. riukiaria) are recently confirmed as validly occurring in the Ryukyu Archipelago, both confined to undisturbed, natural forest habitats. This suggests that the genus might have had a centre of origin in that region.

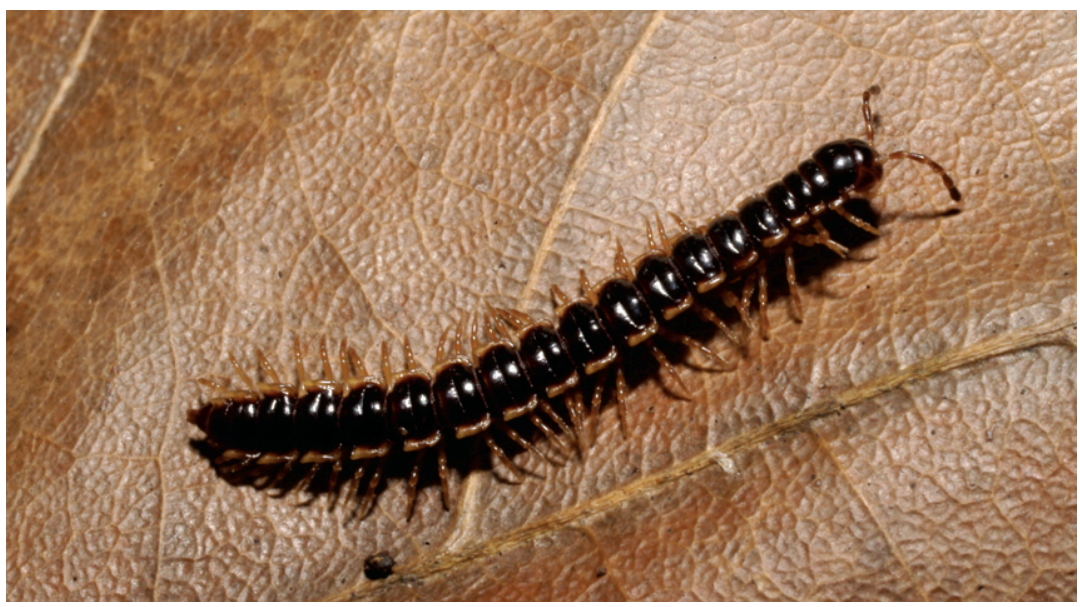




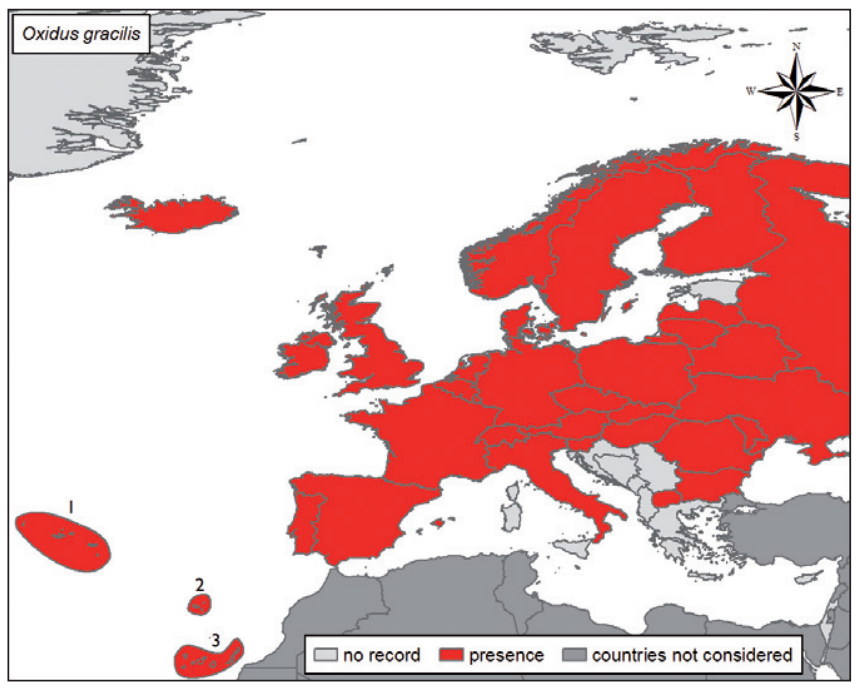

Introduced range: Recorded from 33 European countries, including several Mediterranean islands $(\mathrm{Map})$. Also introduced to numerous temperate and tropical countries: USA, Canada, Puerto Rico, Asian part of Russia, Australia, New Zealand, South Africa, Brazil, archipelagos and isolated islands in Indian and Pacific Oceans: Hawaii, New Caledonia, Madagascar, Sandwich Islands, Seychelles, etc.

Pathways: Must have arrived in Europe with goods from East Asia although when is unknown. Oxidus gracilis is spreading within Europe mainly with expanding trade and greenhouse tropical plant cultivation. Some populations in Central and South Europe have established themselves naturally, most often close to suburban/urban areas, but also in woodlands in nature reserves and in caves.

Impact and management: A plant-damaging millipede regarded as a pest in several European countries. In some places, its density may exceed $2500 \mathrm{ind} . / \mathrm{m}^{2}$. It is known for attacking vegetable and fruit crops such as sugar beet, potatoes, strawberries, cucumbers, orchard fruits, peanut seedlings, roots of wheat, and flowers in outdoor cultivated areas. No data on impact of O. gracilis on native species and its interactions with local invertebrate communities. So far no evidence for wild populations taking over new habitats. The species dies when subjected for two hours to a temperature of $-4^{\circ} \mathrm{C}$. Thus in Northern Europe, it can survive only in hothouse conditions. Various different chemicals such as Methodyl, Carbaryl and Propuxur proved to be effective for dealing with $O$. gracilis. Another effective method for decreasing the numbers of the species in buildings is the removal of all excess damp organic matter and debris from gardens and associated areas.

\section{Selected references}

Blower JG (1985) Millipedes. Keys and notes for the identification of the species. Synopses of the British Fauna 35: 1-242.

Chornyi NG, Golovatch SI (1993) Dvuparnonogie mnogonozhky ravninnych territorij Ukrainy.

[Millipedes (Diplopoda) of the plain areas of the Ukraine]. Kiev: Kiev University. 56 pp. Vicente M, Enghoff H (1999) The millipedes of the Canary Islands. Vieraea 27: 183-204. 


\section{3 - Mermessus trilobatus (Emerton, 1882) (Araneae, Linyphiidae)}

\section{Martin H Schmidt-Entling}

Description and biological cycle: Small, 1.5-2.1 mm long sheetweb spider with orangebrown prosoma* and legs, gray to black opisthosoma*and no markings (Photo). In contrast to most native European sheetweb spiders, the female epigyne* is frequently covered with a dark reddish-brown, hemispherical mating plug. Egg sacs light pink with a smooth surface and 3 $\mathrm{mm}$ diameter. Individual females produce up to 11 egg sacs. Adults are found year-round, and several generations per year are likely. The species builds small horizontal webs low in the vegetation or at the ground surface. Long distance dispersal is by ballooning (also shown by adults), and possibly by passive transport on road, rail or by aircraft.

Native habitat (EUNIS code): Inhabits various types of E - Grassland and tall forb habitats; I1 - Arable land and market gardens; D - wetlands; B - coastal habitats; G - Woodland and forest habitats and other wooded land.

Habitat occupied in invaded range (EUNIS code): The species can reach high densities (exceeding 10 adults per $\mathrm{m}^{2}$ ) in E- Grassland and tall forb habitat, and in ruderal habitats in both rural and urban areas. It is frequently among the ten most abundant spider species in these habitats in Northern Switzerland. It also occurs on I1 - Arable land and market gardens and in G - Woodland and forest habitats and other wooded land.

Native range: Widely distributed in North America from the Gulf coast (Florida, Mexico) to boreal climate (Northwest Territories, Newfoundland) and from the east to the west coast including the Great Plains.

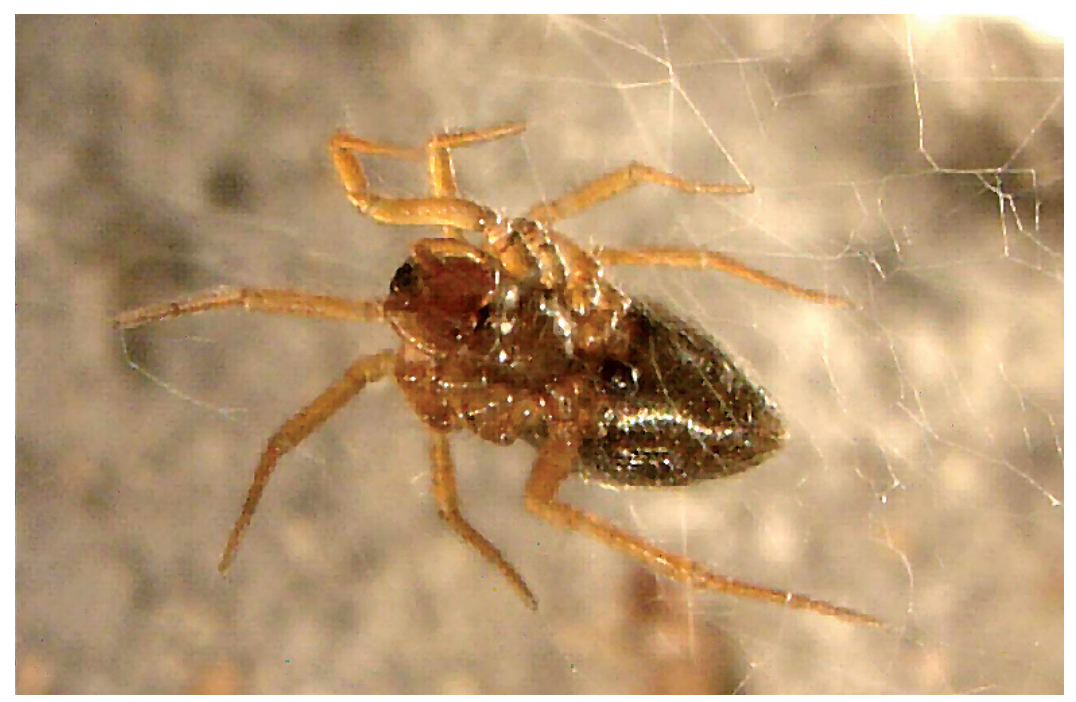




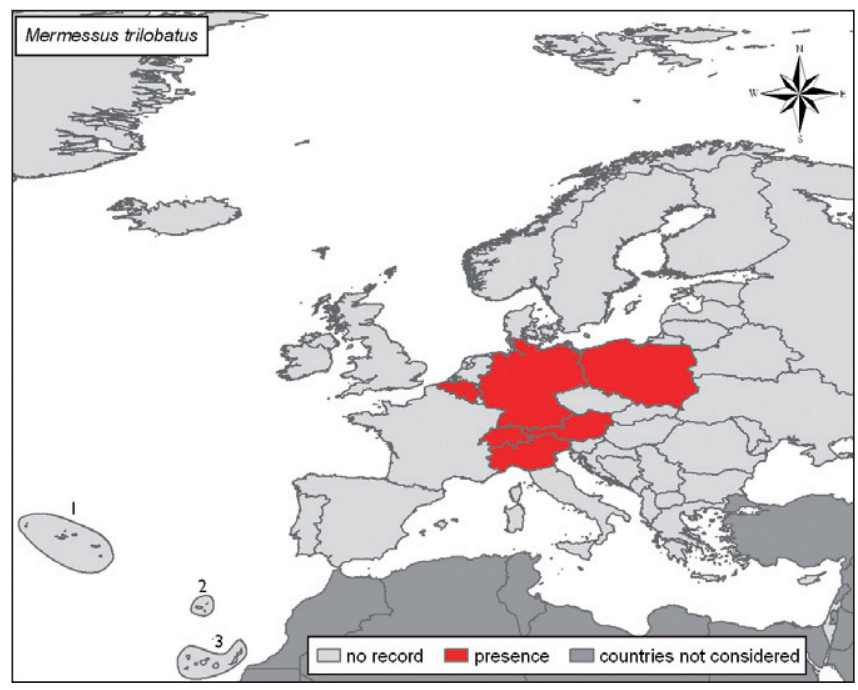

Introduced range: First recorded in 1981 near Karlsruhe, southwestern Germany, $M$. trilobatus spread in all directions with recent records as far as the Netherlands and Italy (near Venice) (Map).

Pathways: Presumably transported unintentionally by aircraft, with no evidence for multiple introductions.

Impact and management: Negative impacts on the native fauna are unknown, but are only starting to be explored. Given the wide distribution and high abundance, prey or other predators may be affected through predation or intraguild interference. $M$. trilobatus was the dominant sheetweb spider in nine protected E3.5 - fen meadows in Switzerland, indicating a potential threat to biodiversity. The species can be effectively recorded with vacuum sampling. It is underrepresented in pitfall traps relative to other spiders. Once established, successful control of $M$. trilobatus appears very unlikely. Specialist natural enemies are not known.

\section{Selected references}

Dumpert K, Platen R (1985) Zur Biologie eines Buchenwaldbodens, 4. Die Spinnenfauna. Carolinea 42: 75-106.

Eichenberger B, Siegenthaler E, Schmidt-Entling MH (2009) Body size determines the outcome of competition for webs among alien and native sheetweb spiders (Araneae: Linyphiidae). Ecological Entomology 34: 363-368.

Schmidt MH, Rocker S, Hanafi J, Gigon A (2008) Rotational fallows as overwintering habitat for grassland arthropods: the case of spiders in fen meadows. Biodiversity and Conservation 17: 3003-3012.

van Helsdingen PJ, IJland S (2007) Mermessus species in the Netherlands (Araneae, Linyphiidae). Nieuwsbrief Spined 23: 27-29. 


\title{
14.4 - Varroa destructor Anderson \& Trueman, 2000 - Bee Varroa (Acari, Varroidae)
}

\author{
Maria Navajas and Yves Le Conte
}

Description and biological cycle: Varroa destructor is today's most important honey bee parasite. As an ectoparasite, the mite causes serious damage to honey bee colonies almost worldwide. Varroa feeds on the hemolymph of adult, larval and pupal bees. Adult females are reddishbrown, 1.00-1.77 mm long and 1.50-1.99 mm wide (Photo-female Varroa on abdomen of Apis mellifera). Adult males are yellowish with lightly tanned legs and spherical body shape measuring $0.75-0.98 \mathrm{~mm}$ long and $0.70-0.88$ wide. The male chelicerae are modified for transferring sperm. Varroa destructor reproduces by pseudoarrenotoky*. The female lays eggs in bee brood cells. Developing mites feed on developing honey bee larvae and pupae. Males and females copulate in capped brood cells. The male dies, but fertilized females emerge from the cell along with their bee host and seek a nurse bee on which it feeds for a few days and then repeat the cycle. In temperate climates, $V$. destructor populations complete an average of 10 generations per year.

Native habitat (EUNIS code): J1- Hives.

Habitat occupied in invaded range (EUNIS code): J1- Hives.

Native range: South East Asia, where it was originally confined on its original host, the Asian honey bee, Apis cerana. Importation of commercial $A$. mellifera colonies into areas with $A$. cerana brought this previously allopatric bee species into contact and allowed $V$. destructor to switch to the new host. While the populations of the parasite reach only a small size within colonies of $A$. cerana and do not damage the colony, infested $A$. mellifera colonies die.

Introduced range: practically worldwide except Australia, the state of Hawaii and some parts of Africa remain free of this pest (see lower Map for known spread routes of Varroa). First reported in the Eastern Europe in the 70s, it spread rapidly all over the continent (see upperMap). Two different genotypes (characterized by mitochondrial DNA sequences) have spread as independent clonal populations: the Korean and the Japanese haplotypes, the later having been found, besides Asia, in The Americas only. International travel and commerce has facilitated the varroa dispersal.

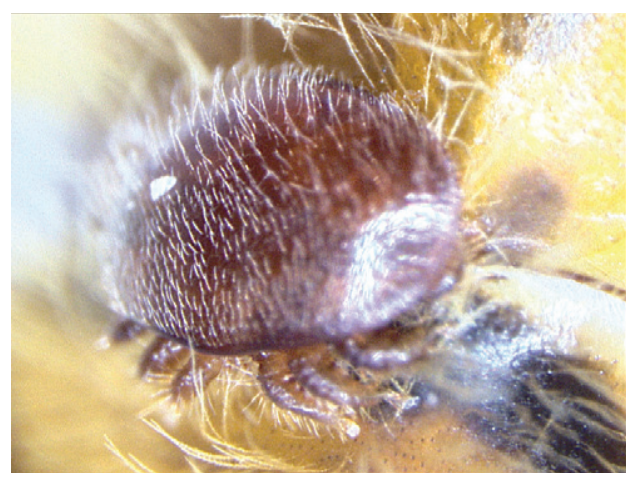




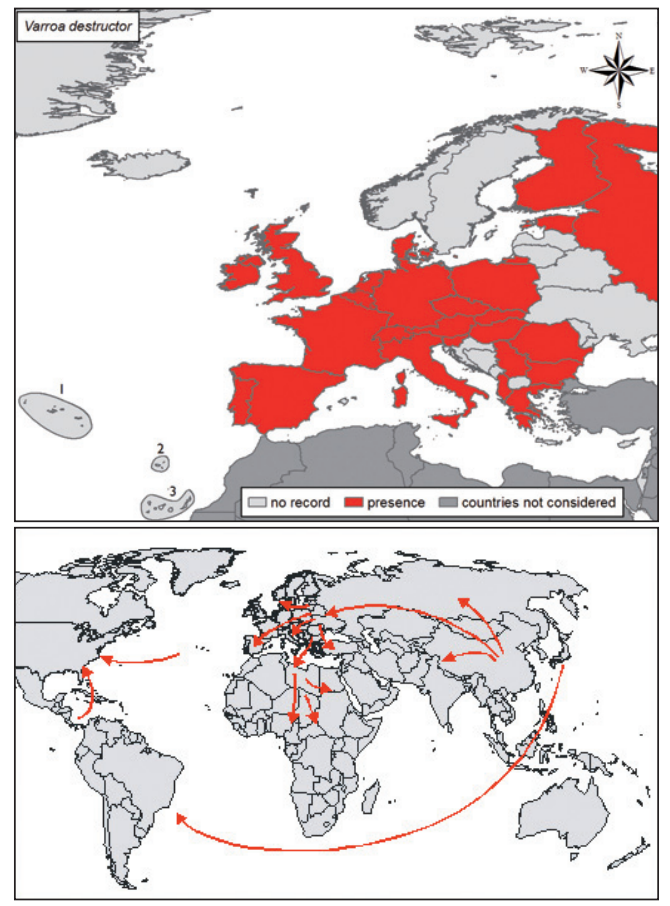

Pathways: Once established in a new region, the mite spread using drifting, robbing, and swarming behaviour of the host. Human mediated varroa dispersion also occurs by apicultural practices. The importation of honey bees from infested areas, and the movement of infested colonies for pollination or hives transhumance* led to the rapid spread of this mite.

Impact and management: Although several chemicals are applied against honey bee larvae and adults, pesticide-resistant varroa populations occur. In addition, there is much concern about chemical residues in hive products. Alternative varroa control methods are attempted, including the use of organic acids, as formic acid, but they are temperature dependent and can be dangerous to humans. Another efficient varroa control is the use of plant volatile essential oil extracts. These different methods used in combination with an integrated pest management (IPM) plan, including bee colony management techniques (e.g. removal of the infested brood) may be helpful. The recent detection of varroa-resistant honeybee stocks is a promising avenue for honeybee breeding.

\section{Selected references}

De Rycke PH, Joubert JJ, Hossein Hosseinian S, Jacobs FJ (2002) “The possible role of Varroa destructor in the spreading of American foulbrood among apiaries." Experimental and Applied Acarology 27: 313-318.

Le Conte Y, de Vaublanc G, Crauser D, Jeanne F, Rousselle JC, Bécard JM (2007) Honey bee colonies that have survived Varroa destructor. Apidologie 38: 566-572.

Martin C, Provost E, Roux M, Bruchoux C, Clément JL, Le Conte Y (2002) Potential mechanism for detection by Apis mellifera of the parasitic mite Varroa destructor inside sealed brood cells by Apis mellifera. Physiological Entomology, 27: 175-188. 


\title{
14.5 - Agrilus planipennis Fairmaire, 1888 - Emerald Ash Borer (Coleoptera, Buprestidae)
}

\author{
Yuri Baranchikov
}

Description and biological cycle: Adults $7-15 \mathrm{~mm}$ long and 3-3.4 mm wide. Body narrow, elongate and metallic coppery-green (Photo left). Eyes large, black- or copper-coloured. Emerald Ash Borer has four larval instars. Mature larvae 26-32 mm long, creamy white with head brown (Photo right). Pre-pupal body characteristically J-shaped. Pupa exarate*, initially beige, later darkening. Adults emerge from ash trees through distinct D-shaped exit holes chewed through the bark. Adults found in June-early August, flying near the host trees and feeding on leaves. After several weeks of maturation, feeding and mating, female deposits up to 270 eggs, singly or in small clusters in bark crevices. Larvae form distinct S-shaped galleries, widening as they grow. Larvae mostly found under the bark during summer and some may be present all year around. Full development takes 1-2 years. All European and most American ash species highly susceptible to infestation. Up to three years's attack can kill a middle-sized ash tree. All species of Fraxinus can be used as hosts. Reportedly, Agrilus planipennis colonize Ulmus, Juglans and Pterocarya in Asia; in the USA it can lay eggs on Ulmus americana, Celtis occidentalis, Carya ovata and Syringa reticulata, but larvae die in early instars.

Native habitat (EUNIS code): G1 - Broadleaved deciduous woodland; G4 - Mixed deciduous and coniferous woodland.

Habitat occupied in invaded range (EUNIS code): G1 - Broadleaved deciduous woodland; G5 - Lines of trees, small anthropogenic woodlands, recently felled woodland, early-stage woodland and coppice; I2 - Cultivated areas of gardens and parks; X24 Domestic gardens of city and town centres; X25 Domestic gardens of villages and urban peripheries.

Native range: North Eastern China, Korea Japan, Taiwan, Eastern Mongolia and the Southern part of the Russian Far East.

Introduced range: First discovered in Michigan, USA, in June 2002 and in Ontario, Canada, in August 2002 (Cappaert et al., 2005). Agrilus planipennis then established in 11 states in North-Eastern USA and adjacent provinces of Canada, expanding very fast. In the early 2000s, introduced to European Russia (see upper Map) where ash trees were killed within

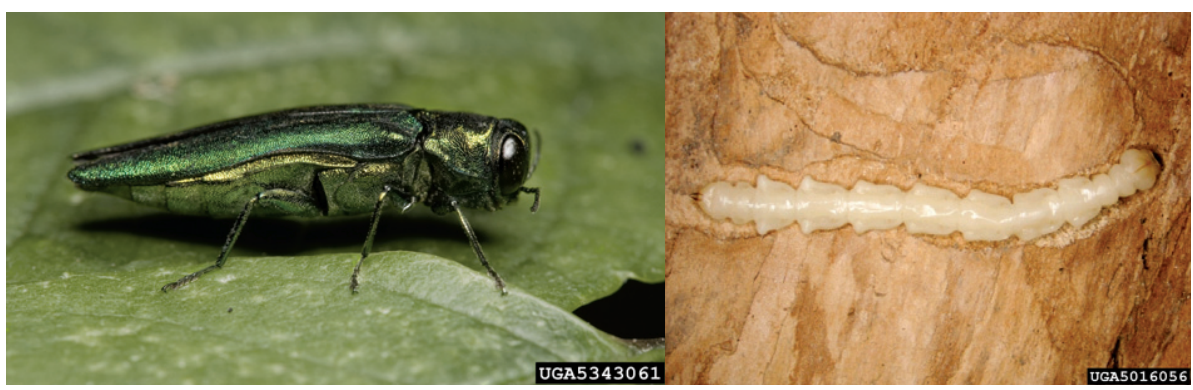




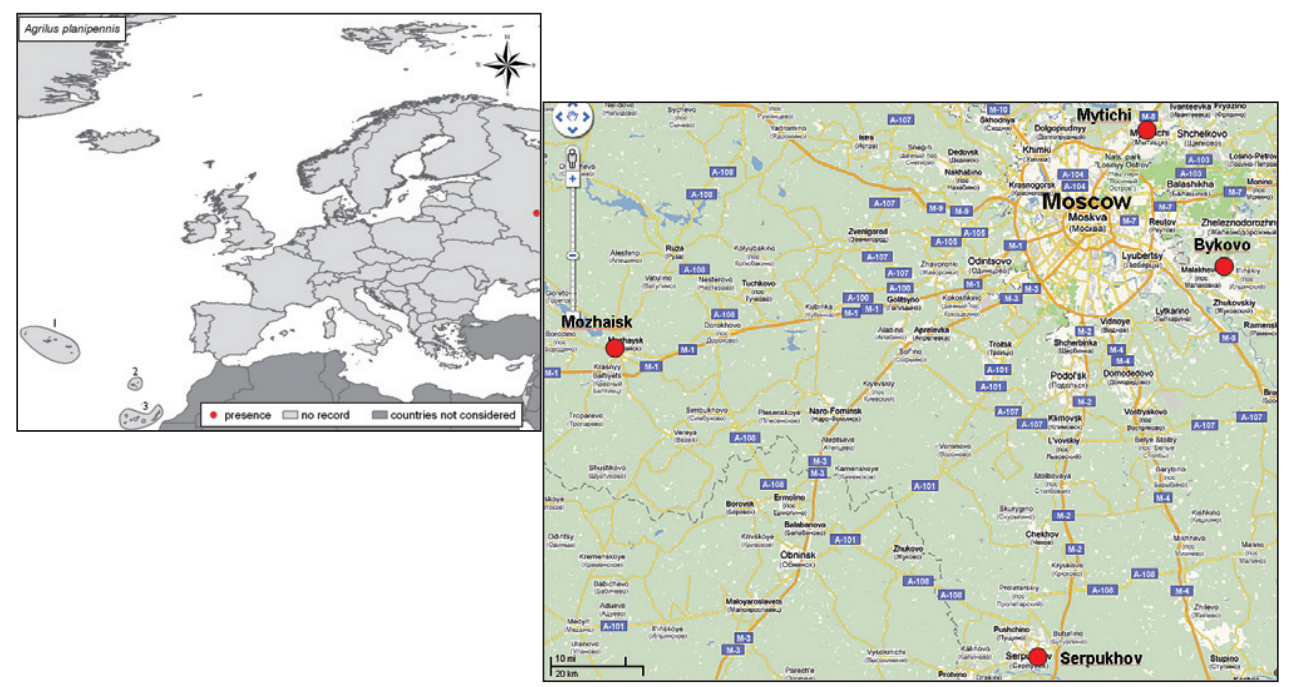

a $100 \mathrm{~km}$ radius of Moscow; since has spread westwards. In approximately 10 years the beetle spread $95 \mathrm{~km}$ to the West, $90 \mathrm{~km}$ to the South, $30 \mathrm{~km}$ to the East and $20 \mathrm{~km}$ to the North. (see lower Map-red points detailing the outer spots of infestation in Moscow area in 2009).

Pathways: transportation with wood for industry and firewood. Adults are active flyers.

Impact and management : In < 10 years, this buprestid killed an estimated over 20 million forest and ornamental trees in North America. In Europe, the ecological impact manifests in fast dieback of all ashes in cities and forests, irrespective of their previous condition. Only Asian species of ashes are relatively resistant to the pest, so the beetle poses one of the most important economic threats to trees in Western Europe. In Asia, controlled by a few hymenopteran parasitoid species: eggs are attacked by Oobius agrili Zhang and Huang (Encyrtidae); larvae are infested by the gregarious endo-parasitoid Tetrastichus planipennisi Yang (Eulophidae) and the gregarious idiobiont ectoparasitoid Spathius agrili Yang (Braconidae). Two other braconids (Spathius depressithorax Belokobylskiy and S. generosus Wilkinson) have been found on larvae in Far Eastern Russia. Woodpeckers are active predators of larvae and pupae. Introduction of some parasitoid species is successfully implemented in the US. Traps with attractants are actively used to monitor spread. A dozen systemic insecticide formulations are used to protect individual ash trees in settlements and historical places.

\section{Selected references}

Anulewicz AC, McCullough DG, Cappaert DL, Poland TM (2008) Host range of the emerald ash borer (Agrilus planipennis Fairmaire) (Coleoptera: Buprestidae) in North America: results of multiple-choice field experiment. Environmental Entomology 37: 230-241.

Baranchikov Y, Mozolevskaya E, Yurchenko G, Kenis M (2008) Occurrence of the emerald ash borer, Agrilus planipennis in Russia and its potential impact on European forestry. Bulletin OEPP/EPPO Bulletin 38: 233-238.

Cappaert D, McCullough DG, Poland TM, Siegert NW (2005) Emerald ash borer in North America; a research and regulatory challenge. American Entomologist 51: 152-165. 


\section{6 - Anoplophora chinensis (Förster, 1848) (=A. malasiaca (Thompson, 1865) - Citrus longhorn beetle (Coleoptera, Cerambycidae)}

\section{Daniel Sauvard}

Description and biological cycle: Large, $21-37 \mathrm{~mm}$ long, stout beetle with shiny black elytra marked with 10-12 white round spots (Photo left). Antennae long, basally marked with white or light blue bands. The larva is a legless grub creamy white in colour, up to 50 $\mathrm{mm}$ long when fully grown (Photo right). Polyphagous insect attacking over 100 species of broadleaved trees and shrubs (Acer, Betula, Carpinus, Citrus, Corylus, Rosa and deciduous shrubs). Adults can fly up to $1.5 \mathrm{~km}$ from their emergence place. Human-mediated longdistance dispersal is possible via infested wood movement or adults hitch-hiking on vehicles. Females lay eggs throughout their lifespan from spring to late summer. Fecundity varies from tens to more than a hundred eggs per female. Full development is achieved in one or two years depending on climate and egg-laying date. Larvae and pupae overwinter inside their tunnels in wood.

Native habitat (EUNIS code): G1- Broadleaved deciduous woodland; G5- Lines of trees, small anthropogenic woodlands.

Habitat occupied in invaded range (EUNIS code): G5- Lines of trees, small anthropogenic woodlands. Prefers subtropical to temperate climate; can survive in a large part of Europe.

Native range: East Asia (China, Taiwan, Korea, Japan, Myanmar, Vietnam).

Introduced range: Italy and a spot in the Netherlands (Map). First recorded in Lombardia, near Milano, Italy in 2000 but probably arrived several years earlier. Increasing frequency of interceptions during the last ten years in Europe. Eradicated in France and Great Britain. Italian populations from Lombardia recently spread in the peninsula, including the Roma area.

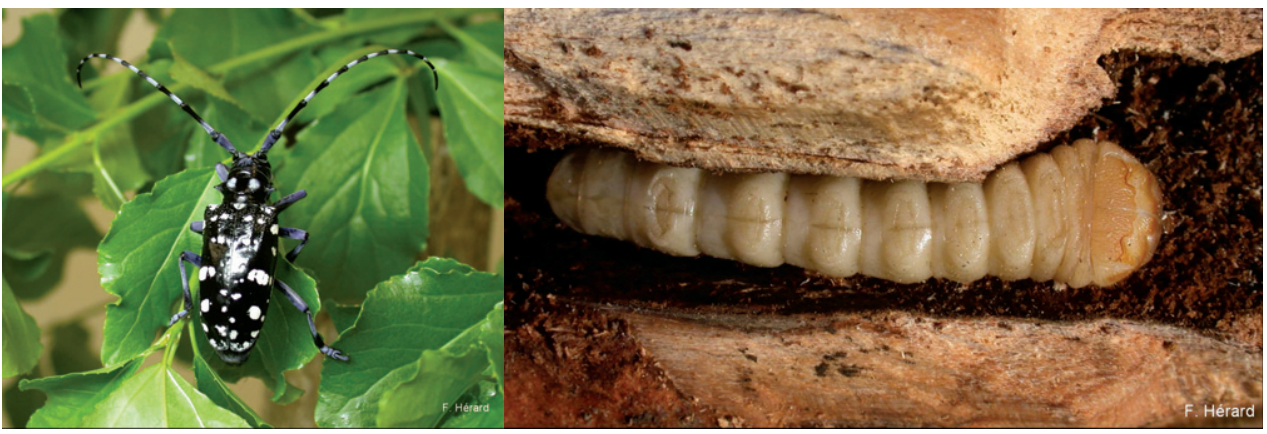

Credit: Franck Hérard 


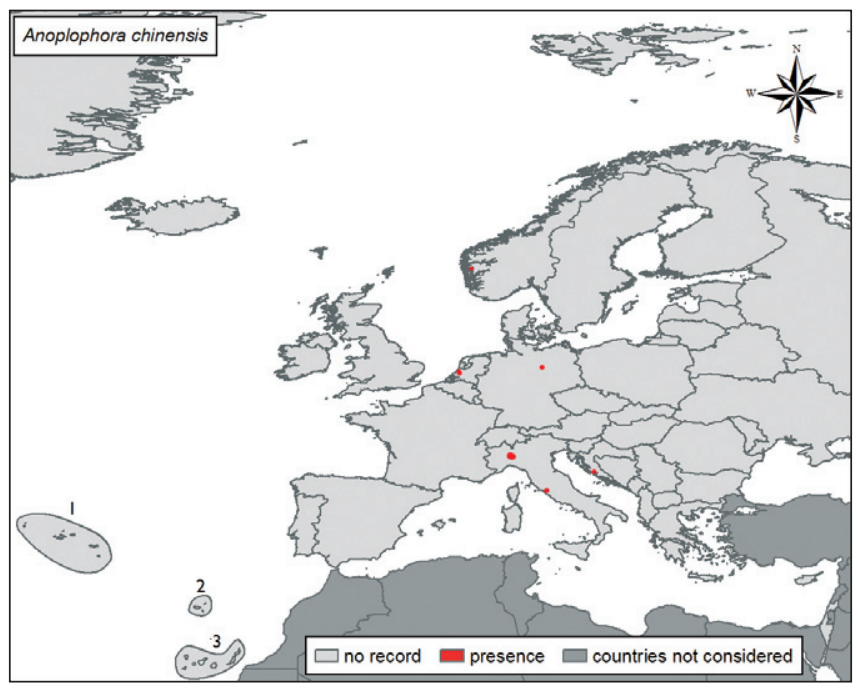

Pathways: Introduced with infested woody materials, especially bonsai plants.

Impact and management: Citrus longhorn beetle may disturb broadleaved forest ecosystems by selective tree killing or via direct/indirect competition with native xylophagous insects, including protected ones. Social impact occurs because in urban areas (streets, private and public gardens) the species kills trees and Rosa shrubs. This is one of the most destructive cerambycid pests of fruit orchards in its native range, especially on Citrus trees. Larval tunnels also depreciate harvested wood. This longhorn beetle is difficult to trap; surveys are generally based on visual detection of damage. Mechanical control involves destruction of infested trees by chipping or burning; trees can also be protected with fine wire meshes to prevent oviposition. Chemical control is of limited effect because the insects are deep within the tree, but systemic insecticides might be used. Biological control using natural enemies (parasitoid insects, entomopathogenic nematodes, fungi or bacteria) is under investigation but not yet being used.

\section{Selected references}

Colombo M, Limonta L (2001) Anoplophora malasiaca Thomson (Coleoptera Cerambycidae Lamiinae Lamiini) in Europe. Bollettino di Zoologia agraria e di Bachicoltura II Ser 33: 65-68.

EPPO (2010) Anoplophora chinensis found again in the Netherlands. EPPO Reporting Services 2: 2010/025.

Hérard F, Ciampitti M, Maspero M, Krehan H, Benker U, Boegel C, Schrage R, BouhotDelduc L, Bialooki P (2006) Anoplophora species in Europe: infestations and management processes. Bulletin OEPP/EPPO Bulletin 36: 470-474. 


\section{7 - Anoplophora glabripennis (Motschulsky, 1853) - Asian longhorned beetle (Coleoptera, Cerambycidae)}

\section{Daniel Sauvard}

Description and biological cycle: Large, stout beetle, $20-35 \mathrm{~mm}$ long with jet-black body and white spotted elytra. Antennae longer than body, black with blue rings at segment base (Photo $u p$ ). The larva is a legless grub up to $50 \mathrm{~mm}$ long when fully grown. It is creamy white in colour, with a chitinized brown mark on the prothorax (Photo down). Xylophagous* species, feeding on a wide range of deciduous trees, mostly species with soft wood such as Acer or Populus where the larvae live inside the wood, in tree boles or large branches. Adults also eat bark on small branches. Adults fly up to $1.5 \mathrm{~km}$ from the emergence place. Possible human-mediated longdistance dispersal by infested wood movement or adults hitchhiking on vehicles. Eggs are laid throughout female life from spring to late summer; fecundity is variable from tens to more than a 100 eggs per female. Full development is achieved in one or two years depending on climate and oviposition date. Larvae and pupae overwinter inside wood tunnels.

Native habitat (EUNIS code): G- Broadleaved deciduous woodland; G5- Lines of trees, small anthropogenic woodlands.

Habitat occupied in invaded range (EUNIS code): G5- Lines of trees, small anthropogenic woodlands. Prefers subtropical to temperate climate; can survive in a large part of Europe up to $S$ Sweden.

Native range: East Asia (China, Taiwan, Korea, Japan)

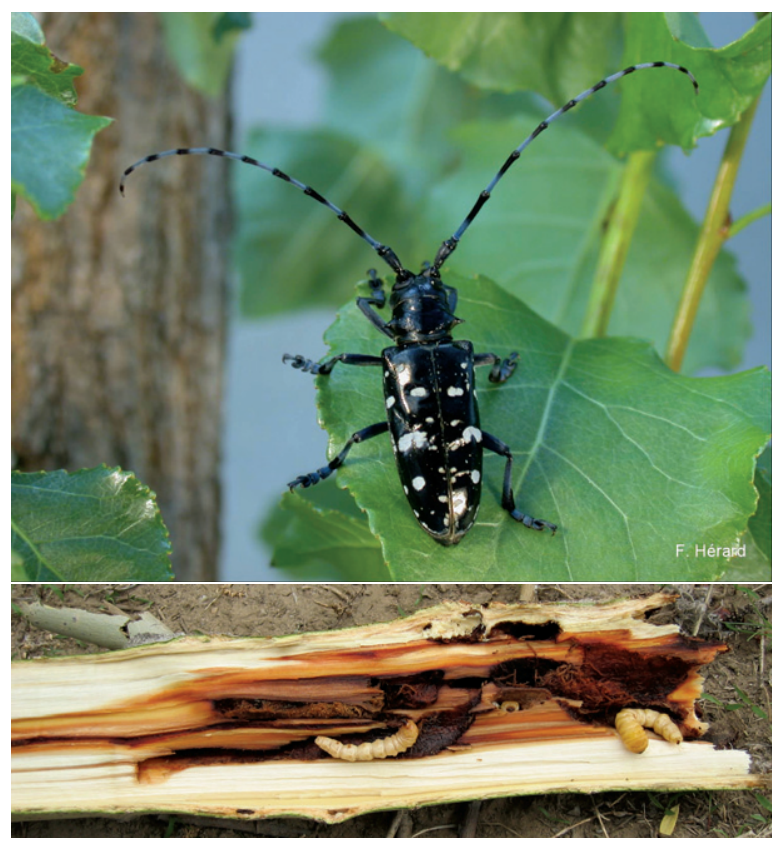

Credit: F. Hérard (above), Alain Roques (below) 


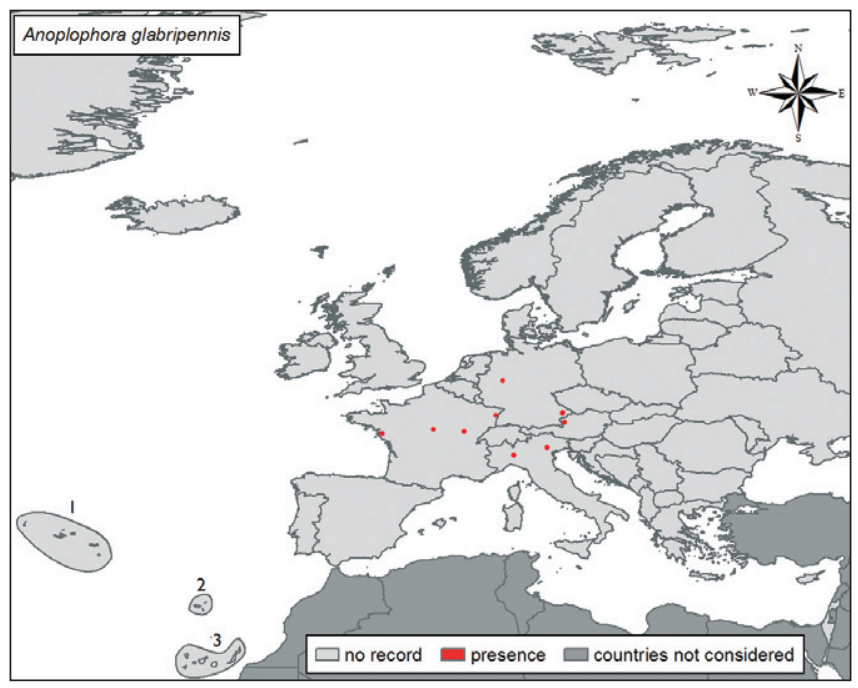

Introduced range: USA, Canada, Austria, France, Germany, Italy (Map). Increasing frequency of interceptions and introductions in Europe during the last ten years. Where the species has been introduced, always in urban areas, eradication attempts have been undertaken.

Pathways: Introduced repeatedly with infested woody materials, especially wood packaging, pallets and waste materials.

Impact and management: May disturb European broadleaved ecosystems by selective tree killing or direct/indirect competition with native xylophagous insects, including protected ones. Social impact occurs because primary introduction is always in urban areas where the beetle weakens or kills trees in streets, private and public gardens. One of the most destructive cerambycid forest pests in its native range, inducing heavy damage in broadleaved stands, including poplar plantations. Larval tunnels also depreciate harvested wood. Difficult to trap; surveys generally based on visual detection of damage. Mechanical control involves destruction of infested trees by chipping or burning; trees can also be protected with fine wire mesh to prevent oviposition. Chemical control is of limited effect because the insects live deep within the tree; systemic insecticides may be tried. Biological control using natural enemies (parasitoid insects, entomopathogenic nematodes, fungi or bacteria) is under investigation but not yet used.

\section{Selected references}

Dauber D, Mitter H (2001) Das erstmalige Auftreten von Anoplophora glabripennis Motschulsky 1853 auf dem europaïschen Festland (Coleoptera: Cerambycidae: Lamiinae). Beiträge zur Naturkunde Oberösterreichs 10: 503-508.

Haack RA, Hérard F, Sun JH, Turgeon JJ (2010) Managing invasive populations of Asian longhorned beetle and Citrus longhorn beetle: A worldwide perspective. Annual Review of Entomology 55: 521-546.

Hérard F, Maspero M, Ramualde N, Jucker C, Colombo M, Ciampitti M, Cavagna B (2009) Anoplophora glabripennis - Eradication programme in Italy (April 2009). http://www.eppo. org/QUARANTINE/anoplophora_glabripennis/ANOLGL_IT.htm. 


\title{
14.8 - Diabrotica virgifera virgifera LeConte, 1868 - Western corn rootworm (Coleoptera, Chrysomelidae)
}

\author{
Wolfgang Rabitsch
}

Description and biological cycle: Small beetle, 5-6 mm long, with pale greenish-yellow body (Photo). Larvae are wrinkled, yellowish-white, with a brown head capsule. The Western corn rootworm is a major crop pest on maize (Zea mays), repeatedly introduced to Europe from North America in the early 1990s, which spreads rapidly. Adult flight dispersal is $20-100 \mathrm{~km}$ per year; intercontinental dispersal occurs via the transfer of goods. Up to 1000 eggs are produced per female during lifespan, laid preferentially in the soil at the base of maize plants. Larvae develop in and on roots of the food plant and adults move upwards and feed on the plant. The species develops as one generation per year. Eggs overwinter in diapause.

Native habitat (EUNIS code): E- Grassland.

Habitat occupied in invaded range (EUNIS code): I: Regularly or recently cultivated agricultural, horticultural and domestic habitats; I1- Arable land and market gardens. Temperature not only influences larval development, but also triggers flight activity which governs the rate of dispersal. Increased habitat diversity slows the rate of spread.

Native range: Probably in the tropics and subtropics of Mexico and Central America.

Introduced range: North America, Europe (Serbia 1992; Croatia, Hungary 1995; Romania 1996; Bosnia and Herzegovina 1997; Bulgaria, Italy, Montenegro 1998; Slovakia, Switzerland 2000; Ukraine 2001; Austria, Czech Republic, France 2002; Belgium, Netherlands, Slovenia, UK 2003; Poland 2005; Germany 2007; Map). Genetic data provides evidence for

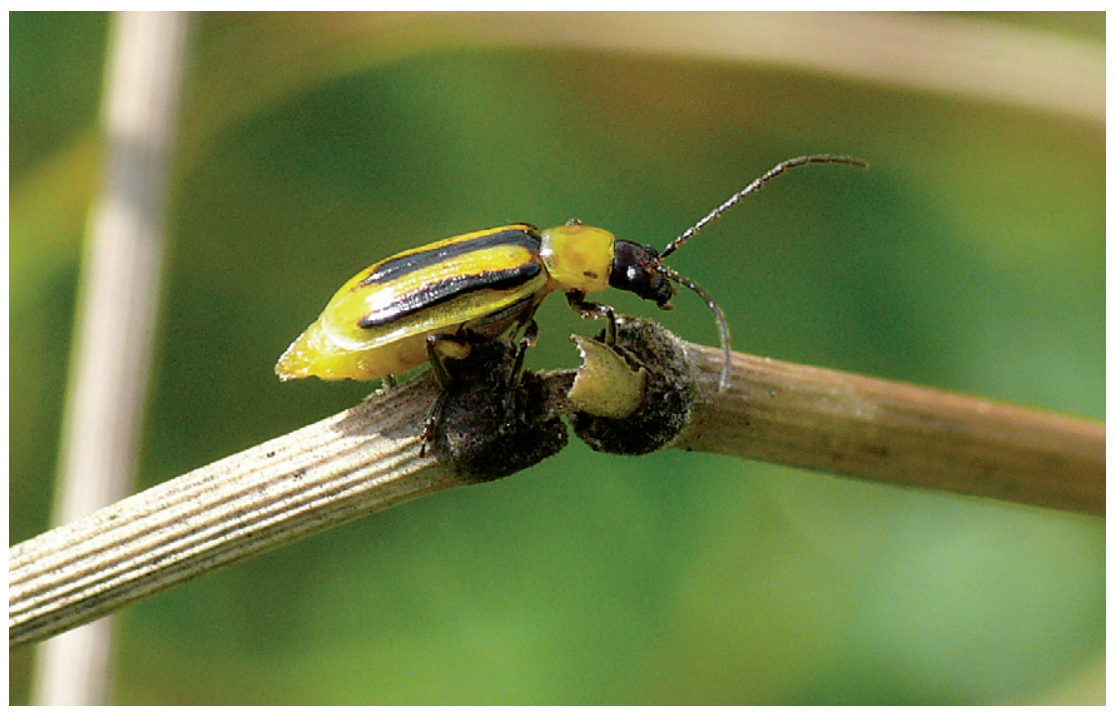

Credit: Margarita Auer 


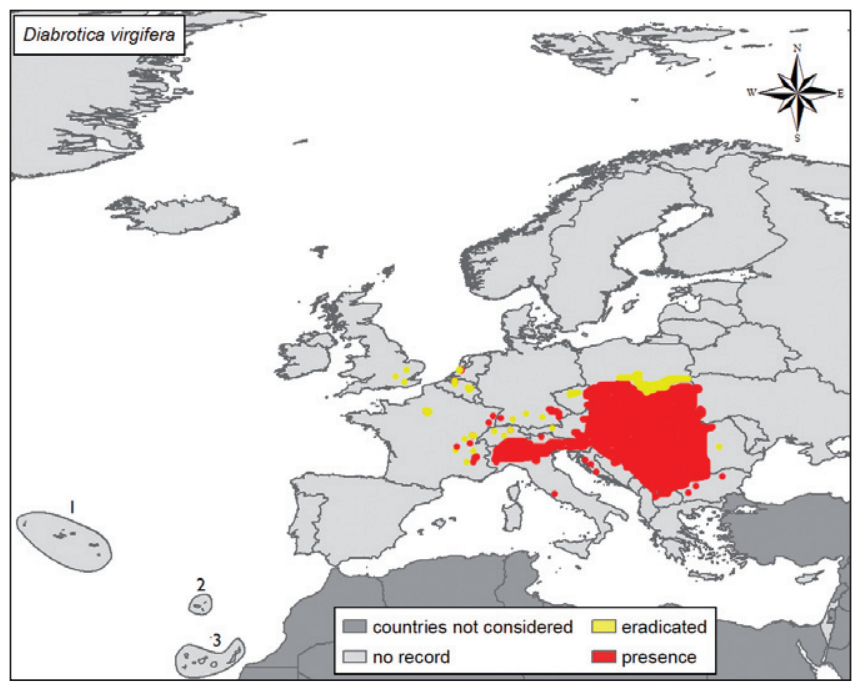

repeated introductions from America (Ciosi et al 2008). Spread in Europe continues and the species is expected to colonize all maize producing countries in Eurasia.

Pathways: Repeatedly transported via vehicles (airplanes, railways, ships).redit : Margarita Auer

Impact and management: Ecosystem impacts including side-effects on non-target species as a consequence of insecticide treatment or biological control are possible, but not demonstrated. This species is regarded as one of the most serious pest species of corn in the USA and its damage to crops and chemical control amounts to 1 billion US\$ per year. Current economic damage in Europe is restricted to some countries, but there is clearly a time lag of several years between the first record and economic damage. Predictive models forecast an economic impact of about 500 million $€ /$ year in Europe. Crop rotation is the most feasible preventative measure, although crop rotation resistant rootworm variants are known in the USA. Monitoring the spread of adults via pheromone-traps is used as a predictor of damage and further treatment is applied in the following season. Chemical control involves several toxicants applied as granular soil insecticides against the larvae and by aerial spraying against adults (spraying is not permitted in most European countries). Biological control using natural enemies (tachinid flies, nematodes, entomopathogenic fungi) is currently under investigation.

\section{Selected references}

Ciosi M, Miller NJ, Kim KS, Giordano R, Estoup A, Guillemaud T (2008) Invasion of Europe by the western corn rootworm, Diabrotica virgifera virgifera: multiple transatlantic introductions with various reductions of genetic diversity. Molecular Ecology 17: 3614-3627.

Kuhlmann U, van der Burgt W (1998) Possibilities for biological control of the western corn rootworm, Diabrotica virgifera virgifera LeConte, in Central Europe. BioControl 19, 59-68.

Vidal S, Kuhlmann U, Edwards CR (2004) Western Corn Rootworm: Ecology and Management. CABI Bioscience, Delémont, 320 pp. 


\section{9 - Epitrix hirtipennis (Melsheimer, 1847) - Tobacco flea beetle (Coleoptera, Chrysomelidae)}

\section{Rumen Tomov}

Description and biological cycle: Adult about 1.5-2 mm long, brown (Photo left). Elytra the same colour as pronotum except on their central areas which are almost black; with rows of fine, distinct punctures, and scattered thin, relatively short brown-yellow setae. Eggs tiny, elongate and white. Fully developed larvae about 4-5 mm long with slender, cylindrical, whitish body and brown head. Pupae white turning darker with anterior end curved downwards. The tobacco leaf beetle is oligophagous on plants of the family Solanaceae: tobacco (Nicotiana tabacum), potato (Solanum tuberosum), tomato (Solanum lycopersicum), aubergine (Solanum melongena), pepper (Capsicum annuum), ground cherry (Physalis pruinosa), jimson weed (Datura stramonium) and horsenettle (Solanum carolinense). Overwinters as adult among debris around fields of host plants or in tobacco seedbeds. Activity resumes in spring feeding on weedy hosts until crop hosts are available. Females lay eggs in the soil near the host plants, which hatch after a week. Larval development lasts 3-4 weeks. Pupal period is 7-10 days, before new generation of beetles emerges. The species develops 3-4 generations per year. Damage is caused by both larvae and adults. Adult beetles feed mainly on leaves in which they produce small round holes (Photo left). The larvae burrow into the soil, living in the roots or tunneling into the stalk (Photo right).

Native habitat (EUNIS code): E- Grassland and tall forb habitats.

Habitat occupied in invaded range (EUNIS code): I- Regularly or recently cultivated agricultural and domestic habitats. The species can also feed on weedy Solanaceae and, thus, is able to invade various types of habitats.

Native range: North America, Canada, Continental US, Mexico

Introduced range Recorded for the first time in 1984 in southern Italy; then spread in the Balkans (Map) and Turkey. Also present in the archipelago of the Azores and of Pacific Ocean (French Polynesia - Tahiti, Hawaii).

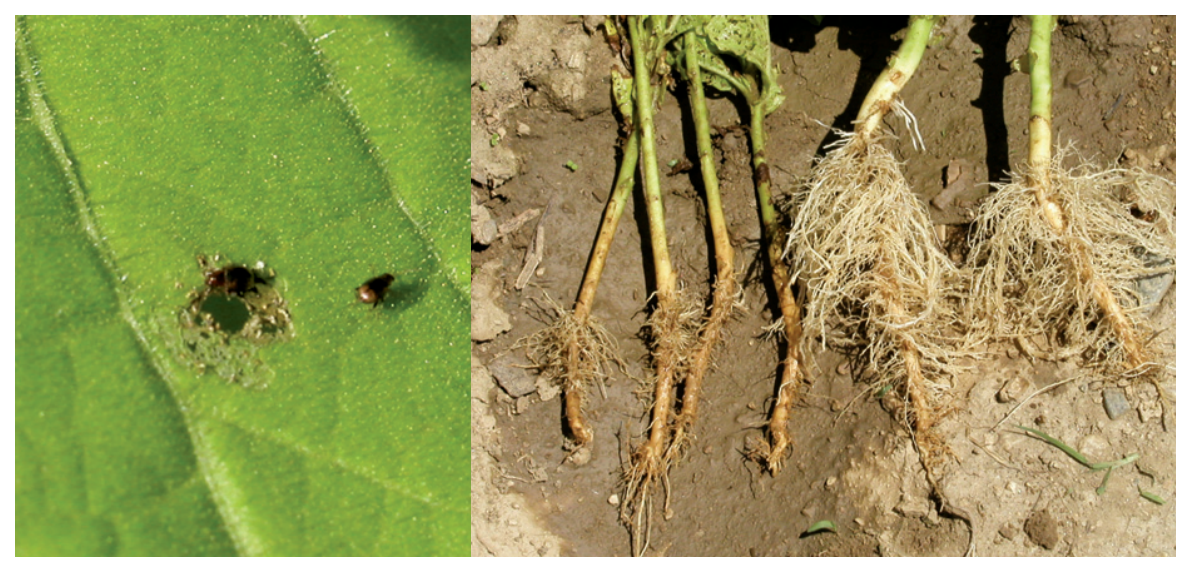




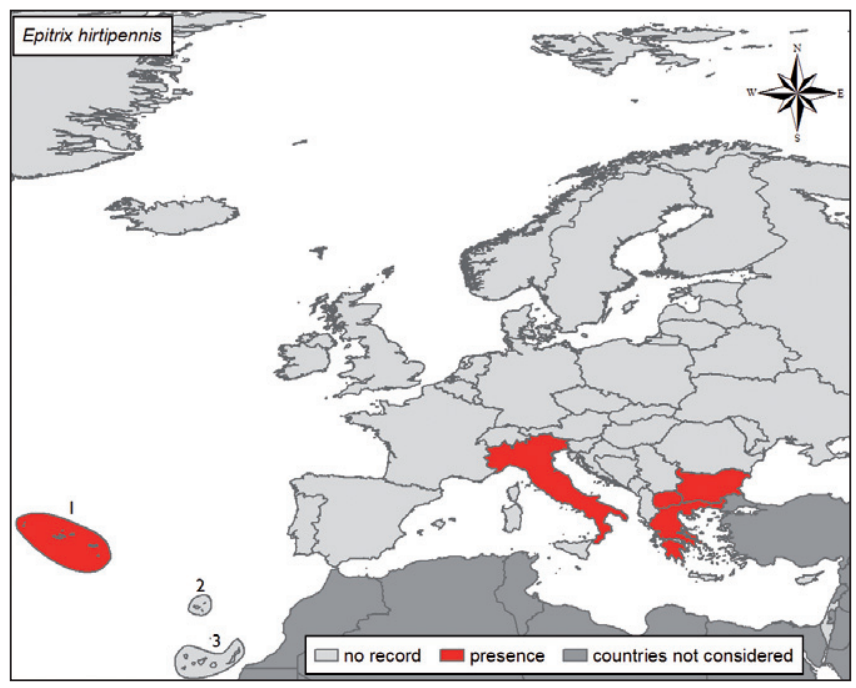

Pathways : The main mode of introduction and spread is the transport of infested plant material. Adults fly actively between fields.

Impact and management: No ecological impact has been reported so far. The species is mainly known as a serious pest of tobacco. It is most dangerous early in the growing season for young seedlings in plant beds. The plants often die after being transplanted into the field. Numerous holes on leaves of mature plants and the adults' excrement delay the growth of plants and reduce the quality and value of tobacco leaves. In heavy infestations, the plant may be totally defoliated like lacework. Both types of attack reduce plant vigour and value, and may ruin an entire plant bed. The pest has been suggested as a vector of Tobacco ringspot nepovirus, which causes significant disease in tobacco. It may also damage potato, aubergine and tomato. Monitoring seedlings is important for early detection of flea beetles. Chemical control involves a number of insecticides for plant bed and the field situations. Biological control using Bacillus thuringiensis ssp. tenebrionis on adults may represent a suitable alternative. Possible cultural control practices include the sterilization or fumigation of top soil before planting and removal of weedy vegetation and excess organic debris in surrounding areas.

\section{Selected references}

Deseo KV, Balbiani A, Sannino L, Zampelli G (1993) Zur Biologie und biologischen Bekampfung des Tabakkafers, Epitrix hirtipennis Melsh. (Col., Chrysomelidae) in Italien. Anzeiger fuer Schaedlingskunde Pflanzenschutz Umweltschutz 66: 26-29.

Lykouressis DP, Mentzos G, Parentis A (1994) The phenology of Epitrix hirtipennis (Mels.)

(Col., Chrysomelidae) and damage to tobacco in Greece. Journal of Applied Entomology 118: 245-252.

Paparatti B, Scubla P (1994) A contribution to the study of the bioethology of Epitrix hirtipennis (Melsheimer) (Coleoptera, Chrysomelidae). Frustula Entomologica 17: 175-184. 


\title{
14.10 - Leptinotarsa decemlineata Say, 1824 - Colorado potato beetle (Coleoptera, Chrysomelidae)
}

\author{
Carlos Lopez-Vaamonde
}

Description and biological cycle: Adults up to $11 \mathrm{~mm}$ long; elytra yellow with ten characteristic black longitudinal bands (Photo). Main natural spread of beetle over large areas is by windborne migration. Females usually deposit eggs on the underside surface of host plant leaves. An egg mass may contain 10-40 eggs. Most adult females deposit over 300 eggs during 4-5 weeks, but they can lay up to 800 eggs. Potatoes are the preferred host, but the Colorado potato beetle (Colorado beetle) may feed and survive on a number of other Solanaceae: eggplant, tomato, pepper, tobacco, ground cherry, horse-nettle, common nightshade, Belladonna, thorn apple, henbane, and its first recorded host plant: buffalo-bur, Solanum rostratum. Larvae are hardy and resistant to unfavourable weather.

Native habitat (EUNIS code): G1- Broadleaved deciduous woodland.

Habitat occupied in invaded range (EUNIS code): I1 - Arable land and market gardens; I2Cultivated areas of gardens and parks. Beetles are sensitive to cold temperatures. They need at least 60 days of temperature over $15^{\circ} \mathrm{C}$ in summer and winter temperatures not falling below $8{ }^{\circ} \mathrm{C}$.

Native range: Mexico, where beetles are still present and feed on wild Solanaceae such as Solanum rostratum.

Introduced range: beetles were accidentally introduced into USA. In 1922, the species was introduced to France from where it expanded almost throughout the European continent (Map) and to parts of Asia in about 30 years. Capable of adapting to different climatic

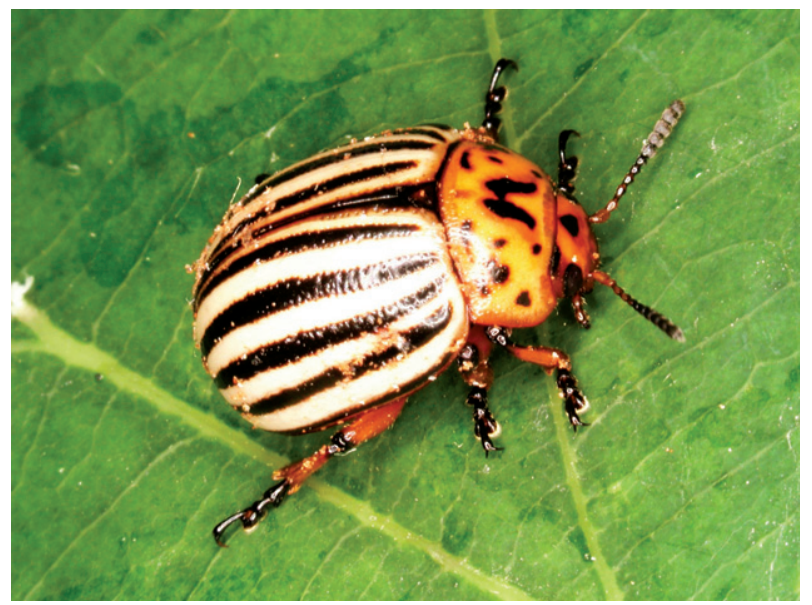

Credit: György Csóka 


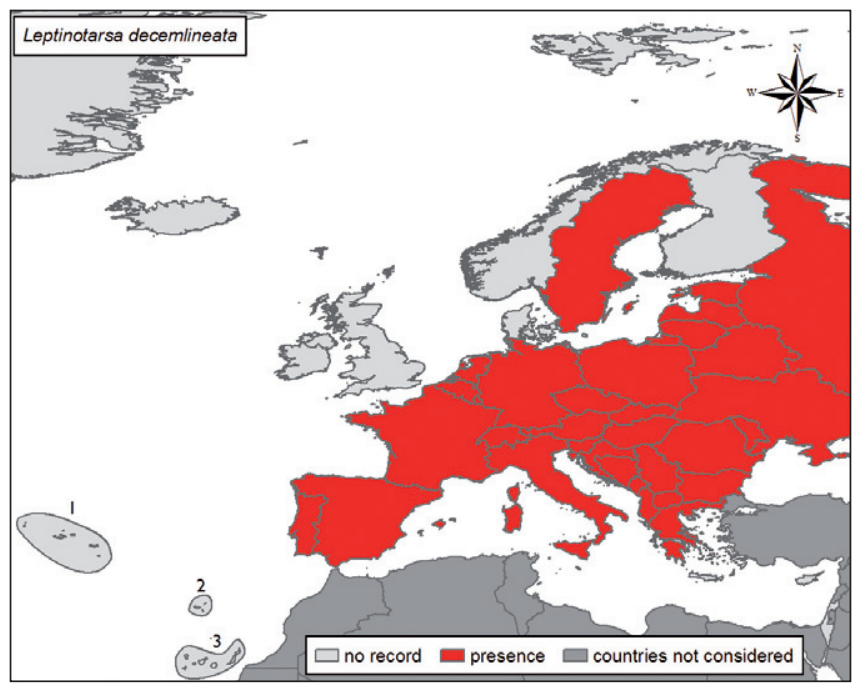

conditions and different host plants, this beetle is constantly moving to new areas. Its distribution is limited by temperature and therefore climate warming could further expand its distribution range.

Pathways: International trade appears to be the most likely pathway for introduction on imported commodities such as fresh vegetables from infested areas. Beetles can also be spread through wind and attachment to all forms of packaging and transport.

Impact and management: Serious pest of potatoes. Both adults and larvae feed on potato leaves and damage can greatly reduce potato yields. Beetles can also be a pest of other solanaceous plants such as tomato, aubergine, tobacco and peppers. This beetle may be managed culturally by crop rotation. Mechanical control involving destruction of crop debris is very effective at reducing population levels. Chemical control commonly involves insecticides, but resistance to them develops rapidly. Biological control includes a long list of natural enemies. Bacillus thuringiensis and some species of nematodes have particularly been used as control agents.

\section{Selected references}

CABI/EPPO (1997) Quarantine pests for Europe, $2^{\text {nd }}$ Ed. Wallingford, UK: CAB International. Grapputo A, Boman S, Lindström L, Lyytinen A, Mappes J (2005) The voyage of an invasive species across continents: genetic diversity of North American and European Colorado potato beetle populations. Molecular Ecology 14: 4207-4219.

Pucci C, Dominici M, Forcina A (1991) Population dynamic and economic threshold of Leptinotarsa decemlineata (Say) (Col., Chrysomelidae) in Central Italy. Zeitschrift für Angewandte Entomologie 111: 311-317. 


\title{
14.11 - Harmonia axyridis (Pallas, 1773) - Harlequin ladybird (Coleoptera, Coccinellidae)
}

\author{
Helen Roy and David Roy
}

Description and biological cycle: Polyphagous predatory ladybird, 5-8 mm long, variable in colour pattern (yellow to orange to black) with a variable number of spots (0-21) (Photoadults mating). Highly dispersive, flying readily between host plants during breeding periods. This species migrates long distances in Asia and America. 20-50 eggs are produced per day, 1000-4000 in their lifetime. Adults typically live for a year, reproducing for three months. The Harlequin ladybird is generally bivoltine but can produce four generations per year in favourable conditions (Majerus et al. 2006).

Native habitat (EUNIS code): G- Woodland, forest habitats and other wooded land.

Habitat occupied in invaded range (EUNIS code): Same range of habitats as in the native range as well as G3- Coniferous woodland; G5- Lines of trees, small anthropogenic woodlands, recently felled woodland, early-stage woodland and coppice; I- Regularly or recently cultivated agricultural, horticultural and domestic habitats; I1- Arable land and market gardens; I2- Cultivated areas of gardens and parks; and, J1- Buildings of cities, towns and villages. The wide native range in Asia shows that the species can reproduce in both warm and cool climates and is well adapted to temperature extremes.

Native range: Central and Eastern Asia.

Introduced range: America, South Africa, Egypt, Europe (Brown et al., 2008). Increasing trend (Map; from Brown et al 2008, modified).

Pathways: Harmonia axyridis was introduced intentionally as a biocontrol agent of aphids and unintentionally in horticultural/ornamental material.

Impact and management: Potential to effect biodiversity, particularly that of other aphidophages and non-pest insects, through resource competition, intraguild predation and direct intra-specific competition. This beetle is also a pest of orchard crops (apples and pears) because as aphids become scarce in autumn, $H$. axyridis feeds on soft fruit, causing blemishing

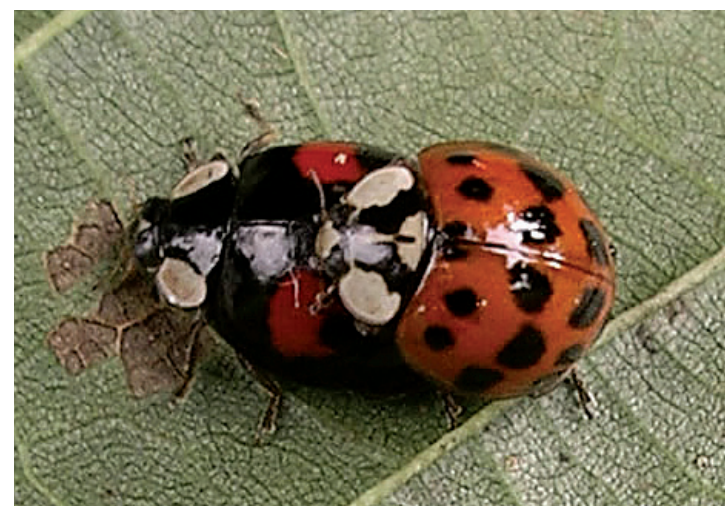




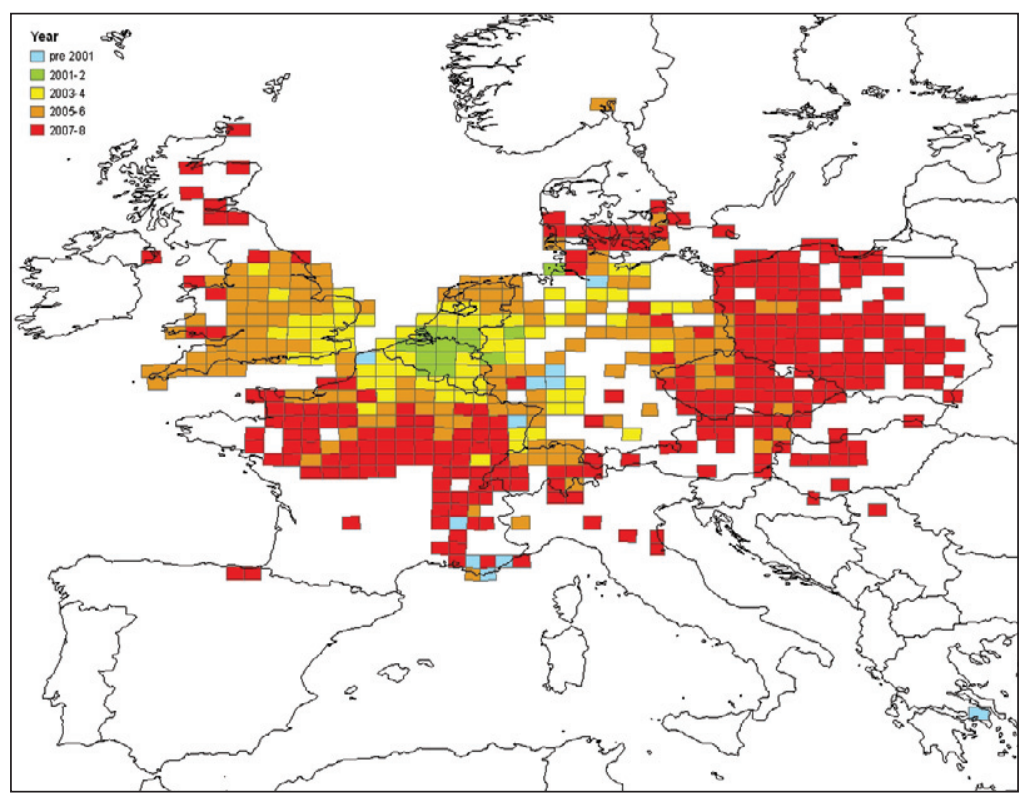

and an associated reduction in the market value. A tendency to aggregate in bunches of grapes prior to harvest makes the ladybirds difficult to separate from the fruit and so they are sometimes processed during wine making. Alkaloids contained within these beetles adversely affect the taste of the vintage.

The beetle's propensity to swarm and its large winter indoors aggregations are regarded as a nuisance. Economic impact is mainly on the wine industry, with reduction in fruit quality and management measures required in domestic dwellings (Kenis et al., 2008). Preventing the use of $H$. axyridis as a biocontrol agent and ensuring that fruit and cut flower imports are clean will reduce introduction events. Invasion into households can be limited by covering entrances with fine mesh. Adults and late instar larvae can be removed from unwanted locations manually, e.g., using a vacuum cleaner. Light traps can attract adults but the efficiency of these is not yet quantified. Chemical control in field situations such as orchards and vineyards is not applicable because of the impact of insecticides on other aphidophages and beneficial insects (Kenis et al., 2008).

\section{Selected references}

Brown PMJ, Adriaens T, Bathon H, Cuppen J, Goldarazena A, Hagg T, Kenis M, Klausnitzer BEM, Kovar I, Loomans AJ, Majerus MEN, Nedved O, Pedersen J, Rabitsch W, Roy HE, Ternois V, Zakharov I, Roy DB (2008) Harmonia axyridis in Europe: spread and distribution of a non-native coccinellid. BioControl, 53: 5-22.

Kenis M, Roy HE, Zindel R, Majerus MEN (2008) Current and potential management strategies against Harmonia axyridis. BioControl, 53: 235-252.

Majerus MEN, Strawson V, Roy HE (2006) The potential impacts of the arrival of the Harlequin ladybird, Harmonia axyridis (Pallas) (Coleoptera: Coccinellidae), in Britain. Ecological Entomology, 31: 207-215. 


\subsection{2 - Gonipterus scutellatus Gyllenhal 1833 - Eucalyptus snout beetle (Coleoptera, Curculionidae, Cyclominae)}

\section{Daniel Sauvard}

Description and biological cycle: Medium-sized weevil species (12-14 mm), grey to brown with a light transverse band on the elytra and pale brown hairs (Photo left-adult on eucalyptus branch). This species is morphologically very similar to another Australian eucalyptus weevil, $G$. gibberus, invasive too but not present in Europe at this time. Hosts are different Eucalyptus species. The weevil has several generations per year (generally two in southern Europe). The adults emerge from the soil and feed on leaves (see Figure 8.2.6 in Chapter 8) and growing shoots. Throughout their life, females lay several egg batches protected by brown capsules on surfaces of young leaves (overall fecundity of a female is about 150-300 eggs). Yellowish-green larvae feed on leaves (Photo right-larval damage) and twigs, then fall on the ground and pupate in the soil. Overwintering occurs in the adult stage.

Native habitat (EUNIS code): G2- Broadleaved evergreen woodland.

Habitat occupied in invaded range: G2- Broadleaved evergreen woodland; G5- Lines of trees, small anthropogenic woodlands; I2- Cultivated areas of gardens and parks; X-parks and gardens.

Native range: Southeastern Australia.

Introduced range: Progressively introduced in all places where eucalyptus have been introduced: USA, South America, Western Australia, New Zealand, China, South and East Africa. In Europe, the Eucalyptus snout beetle was first recorded in Italy in 1990 and then in other Mediterranean countries (Map).

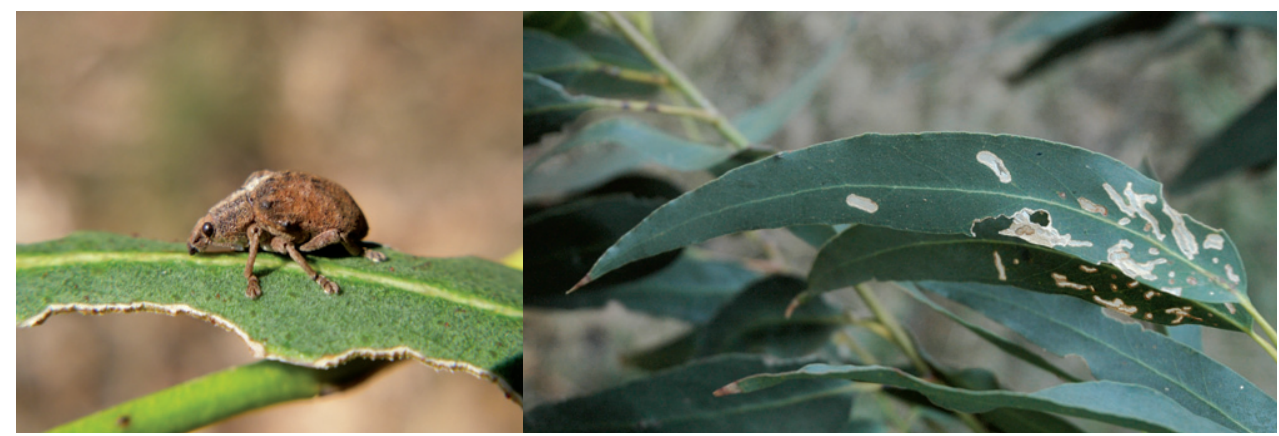

Credit:Alain Roques 


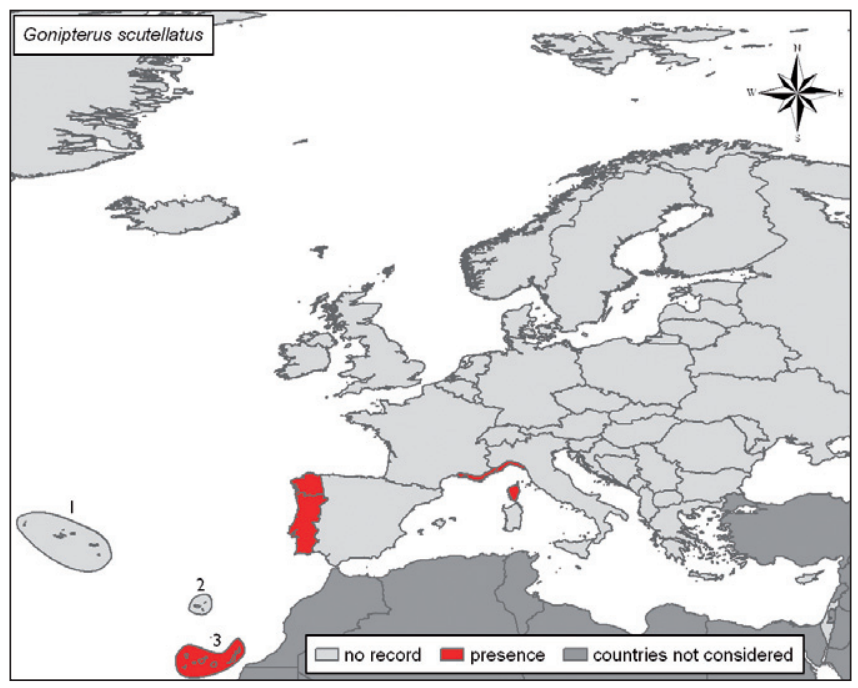

Pathways: Adults, eggs and larvae can be transported with live eucalyptus; larvae and pupae can be transported with soil. The adults can fly to disperse locally; adult may hitch-hike, e.g. on vehicles.

Impact and management: This weevil is an important eucalyptus pest in all areas where it has been introduced. Adults and especially larvae damage eucalyptus leaves, mainly young ones. Larvae characteristically damage only one surface of leaves, while adults chew the edge. Defoliation causes growth reduction, and even tree mortality in case of successive severe damage. Young trees are generally the most damaged. Susceptibility depends of Eucalyptus species; in Europe, the commonly planted E. globulus is one preferred host. Chemical control is not recommended due to side effects on honey bees often visiting eucalytus flowers. Biological control has been successfully achieved in several world and European countries using the Australian chalcid Anaphes nitens (Girault 1928) (Hymenoptera, Mymaridae), an egg parasitoid.

\section{Selected references}

Arzone A (1976) Un nemico dell'Eucalipto nuovo per l'Italia. Apicoltore Moderno 67: 173-177. Mansilla JP, Pérez Otero R (1996) El defoliador del eucalipto Gonipterus scutellatus. Phytoma España 81: 36-42.

Rabasse JM, Perrin H (1979) Introduction en France du charançon de l'eucalyptus, Gonipterus scutellatus Gyll. (Col., Curculionidae). Annales de Zoologie, Écologie Animale 11:336-345. 


\title{
14.13 - Rhopalapion longirostre (Olivier 1807) (= Apion longirostre) - Hollyhock weevil (Coleoptera, Apionidae)
}

\author{
Katalin Tuba and Ferenc Lakatos
}

Description and biological cycle: Small weevil species distinguished from other Apion and Aspidapion species by its orange legs and enormously narrow rostrum* (Photo-adults mating on Alcea leaf) The females have one of the longest rostra among all Middle-European Apionidae, longer than half the remaining body length which is $3-3.5 \mathrm{~mm}$. Their black or rarely yellowish antennae are located halfway along this snout. The greyish-black body is densely hairy. Hosts are different Alcea species, especially $A$. rosae (Malvaceae). It develops on hollyhock with other host specialist Apionidae species, like Aspidapion aeneum, A. radiolus and Alocentron curvirostre. The hollyhock weevil has one generation per year. The adults overwinter under fallen leaves or in the soil around the stem. In spring the adults come out and chew the leaves, the petioles and the stem. The females lay eggs at the bottom of the buds or on young ornamental or herbaceous plants. The larvae develop by chewing seeds and sometimes leaf tissue. Adults emerge from the seeds in August-September.

Native habitat (EUNIS code): G- Woodland and forest habitats and other wooded land; I: Regularly or recently cultivated agricultural, horticultural and domestic habitats.

Habitat occupied in invaded range (EUNIS code): I2 - Cultivated areas of gardens and parks.

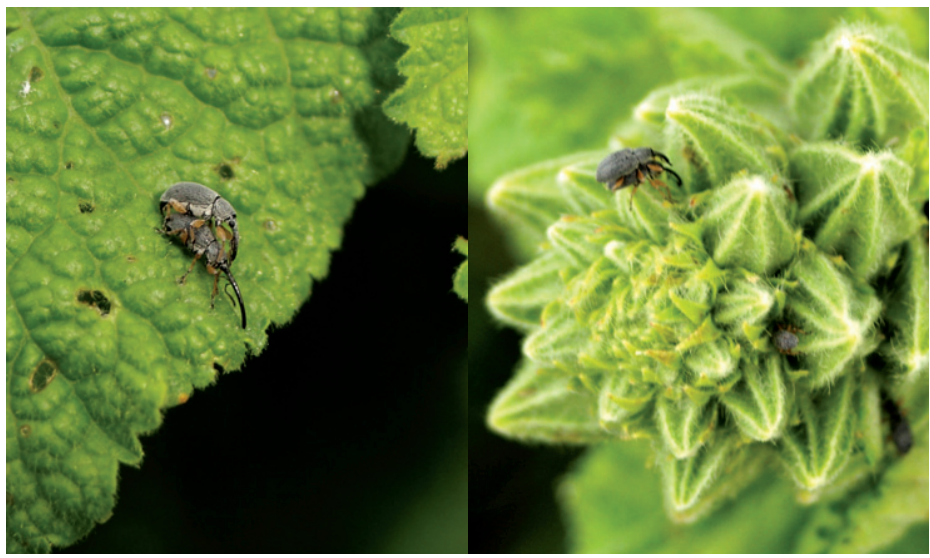

Credit: Ferenc Lakatos 


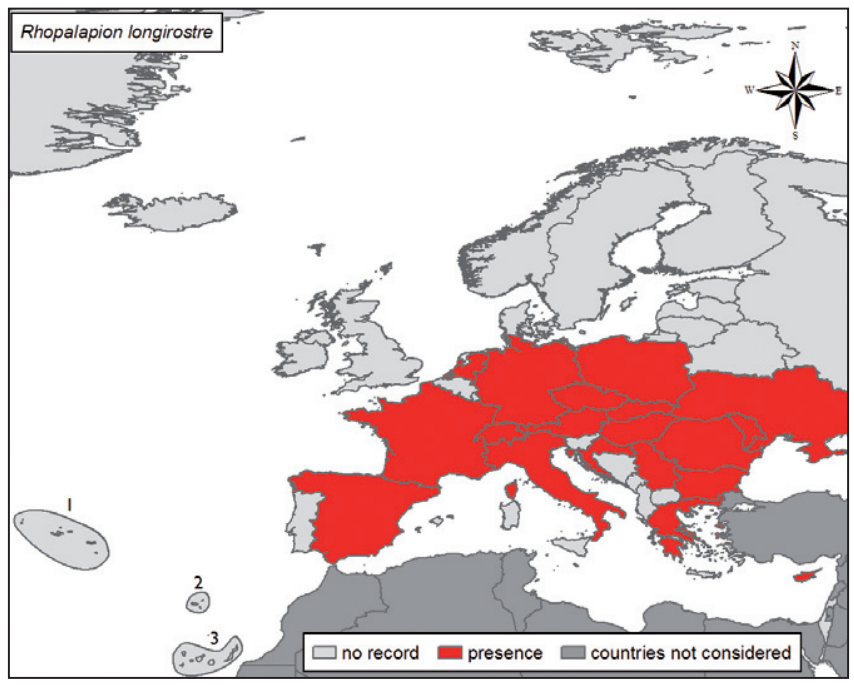

Native range: Temperate Asia.

Introduced range: First detected in 1875 in Romania. Then, observed in most of the Mediterranean and Central-European countries (Map). Also introduced in North America since 1914 in Georgia.

Pathways: Probably trade of ornamentals.

Impact and management: This species can spread very quickly due to its distinct habit and special host plant especially in urban gardens. It can cause serious ecological damage in hollyhock cultivation as ornamentals or herbs. Both chemical and biological control is possible against this insect. However application is recommended mainly in production circumstances rather than garden situations.

\section{Selected references}

Ehret JM (1983) Apion (Rhopalapion) longirostre, espèce nouvelle pour la France (Coleoptera, Curculionidae). L'Entomologiste 39: 42.

Kozłowski MW, Knutelski S (2003) First evidence of an occurrence of Rhopalapion longirostre in Poland. Weevil News 13: 4 pp. http://www.curci.de/Inhalt.html.

Perrin H (1984) Présence en France d'Apion (Rhopalapion) longirostre (Olivier) (Coleoptera, Curculionidae, Apioninae) et répartition dans la région paléarctique. L'Entomologiste 40: 269-274. 


\subsection{4 - Trogoderma granarium (Everts, 1898) (= T. khapra (Arrow, 1917)) (= T. afrum (Priesner, 1951)) - Khapra beetle (Coleoptera, Dermestidae)}

\section{Katalin Tuba and Ferenc Lakatos}

Description and biological cycle: Adults of this tiny beetle species are ovate and densely haired (Photo-Adult, larva, larval skins and damage to wheat grains). Males are 1.4-2.3 mm long and 0.75-1.1 mm wide, while females are slightly larger and lighter in colour. Head and pronotum are dark reddish-brown, while elytra are reddish brown with two or three lighter, indistinct bands. Legs are yellowish-brown. Antennae consist of 10-11 segments; the last 3-4 segments at females and the last 5 segments at males forming a club. Antennae are yellowish-brown. Eggs are $0.7 \mathrm{~mm}$ long and $0.25 \mathrm{~mm}$ wide, cylindrical, milky white, turning pale yellowish with age. At the end of the embryonic development, six brown bands are visible in the eggs. Generally there are 6-8 larval stages, but under unfavourable development conditions, up to 10-12. A tail on the last abdominal segment is half of the whole larval body length. Larval body is yellowish-white with brown head and setae. Mature larva is $4-6 \mathrm{~mm}$ long and $1.5 \mathrm{~mm}$ wide. Male pupa is $3.5 \mathrm{~mm}$ long and female $5 \mathrm{~mm}$, both sexes yellowish-brown and hairy. The khapra beetle has one to nine generations per year depending on nutritional resources, temperature, humidity, light and season. Each female lays a total of 50-100 eggs on host material. Development time varies between 26-220 days. Egg stage takes 3-14 days, while larvae live 4-6 weeks. Larvae can enter diapause if the temperature falls below $25^{\circ} \mathrm{C}$ and may remain in this condition for many years. The pupa stage takes 2-5 days. Adult khapra beetles have wings, but are not known to fly and feed very little. Mated females live from 4-7 days, unmated females from 20-30 days, and males from 7-12 days.

Habitat occupied in invaded range (EUNIS code): J-Constructed, industrial and other artificial habitats.

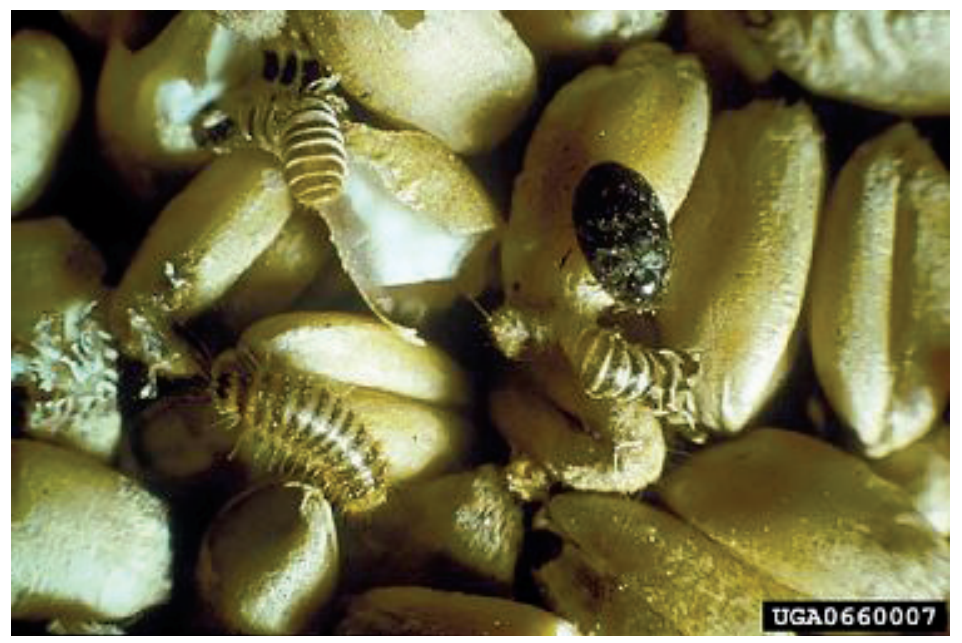

Credit: Ministry of Agriculture and Regional Development Archives of Hungary, bugwood.org 


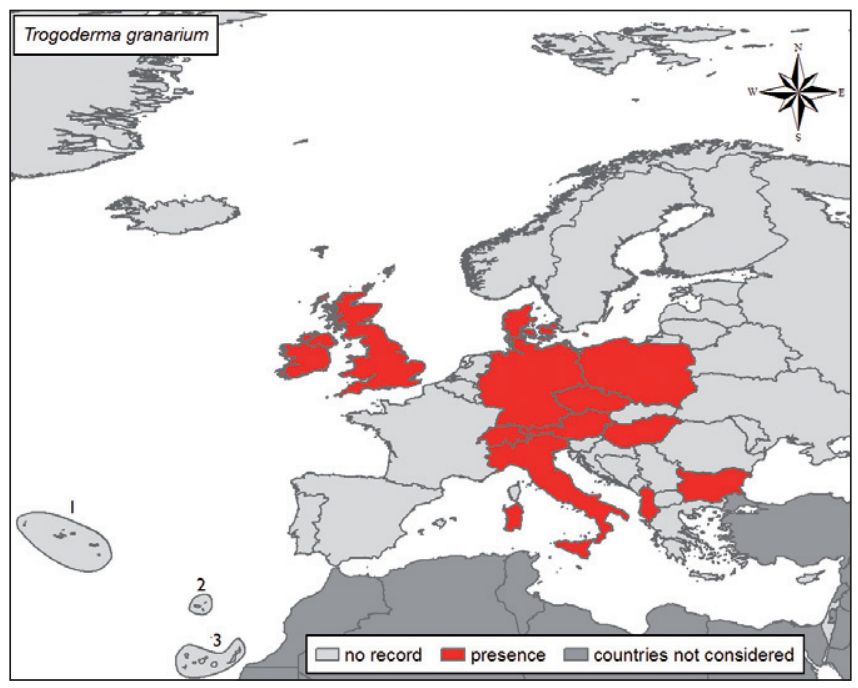

\section{Native range: India.}

Introduced range: all over the word except for Australia and New Zealand. Warmer climates are preferred, living in stores further north. The khapra beetle first moved into Europe in 1908. At first the eradication was successful but during the First World War, the species was introduced again and became established.

Pathways: The wide geographical distribution of this pest is to a certain extent due to human activities. In the absence of flight, its spread is dependent on movement of infected goods. The species can spread with containers in which it diapauses.

Impact and management: This polyphagous species is one of the most important and dangerous insect pest of the stored products. The gregarious larvae damage both quality and quantity of stored foodstuff, chewing seeds, while adults cause negligible damage. Food produce attacked includes grain and cereal (wheat, barley, oats, rye, maize, rice, flour, pasta) as well as beans, herbs, chocolates, nuts and many other products. Both physical and chemical control can be used against this insect but it is one of the most difficult detritivorous pests to manage. Established infestations are difficult to control and eradicate because the larva can live without food for long time and it can crawl and slip into tiny cracks and crevices, and is resistant towards many insecticides.

\section{Selected references}

Harris DL (2006) Trogoderma granarium Everts (Insecta: Coleoptera: Dermestidae). http://entnemdept.ufl.edu/creatures/urban/beetles/khapra_beetle.htm. [accessed 25 February 2010]. Jenser G., Mészáros Z, Sáringer Gy (Eds) (1998) A szántóföldi és a kertészeti növények kártevői. Mezőgazda Kiadó Budapest: 157-158.

Szőnyegi S, Kalmár K (1999) Szemestermény tárolók károsítói és az ellenük való védekezés.

Agroinform Kiadó Budapest: 49-50. 


\title{
14.15 - Diocalandra frumenti (Fabricius, 1801) - Four-spotted coconut weevil (Coleoptera, Dryophthoridae)
}

\author{
Wolfgang Rabitsch
}

Description and biological cycle: Curculionid beetle, shiny black with four large red to brown spots on the elytra. Length of adults is $6-8 \mathrm{~mm}$. Larvae bore galleries in roots, petioles, infloresences and fruits of palms, where they pupate (Photo left-pupal chambers in a palm frond). Adult emergence is noticed by round holes (Photo right-Adult emerging from a palm tree and emergence holes) The whole life-cycle takes 10-12 weeks. Larvae cause premature yellowing and collapse of palm fronds as well as shedding of fruits and may cause the death of the tree. This weevil causes damage to many palm species, including economically important and ornamental species (Cocos nucifera, Phoenix dactylifera, P. canariensis and Elaeis guineensis).

Native habitat (EUNIS code): G2.5- Palm groves.

Habitat occupied in invaded range (EUNIS code): G2.5- Palm groves; I- Regularly or recently cultivated agricultural, horticultural and domestic habitats.

Native range: Southeast Asia.

Introduced range: In Europe, it was found in the south of Gran Canaria, the Canary Islands, in 1998, on the endemic palm Phoenix canariensis. It has also established on the islands of Tenerife, Lanzarote and Fuerteventura, where it occurs in several protected areas. Also intro-

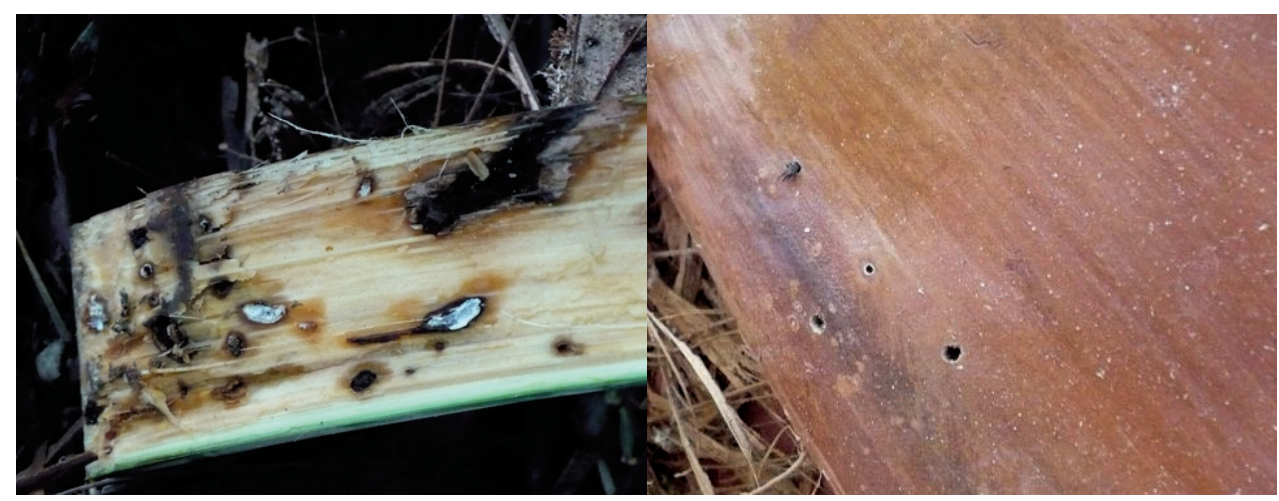

Credit: EPPO 


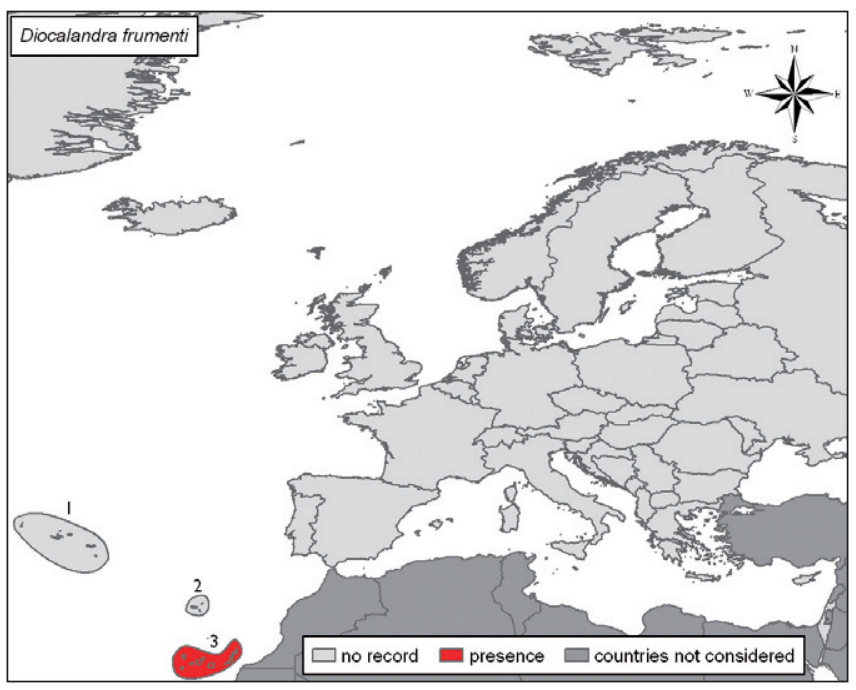

duced in South Asia (Bangladesh, India, Indonesia, Malaysia, Philippines, Sri Lanka, Taiwan, Thailand), Japan (Ryukyu), East-Africa, Madagascar, Seychelles, Oceania (Australia, Guam, Palau, Papua New Guinea, Samoa, Solomon Islands, Vanuatu), and South America (Ecuador).

Pathways: Probably with ornamental trade

Impact and management: Introduction occurs with infested ornamental palm trees. $D$. frumentii is a threat to native Canary Islands Date Palm and it may change the fire regime and the structure, abundance and succession of invaded habitats. Detection and control is difficult due to the secretive life habit.

\section{Selected references}

González Núñez M, Jiménez Álvarez A, Salomones F, Carnero A, Del Estal P, Esteban Durán JR (2002) Diocalandra frumenti (Fabricius) (Coleoptera: Curculionidae), nueva plaga de palmeras introducida en Gran Canaria. Primeros estudios de su biología y cría en laboratorio. Boletín de Sanidad Vegetal Plagas, 28(3): 347-355.

Samarin Bello CR (2008) Diocalandra frumenti (Fabricius, 1801). In: Silva L, Ojeda Land E, Rodríguez Luengo JL (Eds) Invasive Terrestrial Flora \& Fauna of Macaronesia. Top 100 in Azores, Madeira and Canaries. ARENA, Ponta Delgada, pp. 418-420. 


\title{
14.16 - Rhynchophorus ferrugineus (Olivier, 1790) - Red Palm Weevil (Coleoptera, Dryophthoridae)
}

\author{
Wolfgang Rabitsch
}

Description and biological cycle: Curculionid beetle, reddish-brown, with dark spots on elytra (Photo- see also Figure 8.2.7a in Chapter 8). Length of adults is $3.5 \mathrm{~cm}$, length of larvae $5 \mathrm{~cm}$. Females bore small holes in the trunk of a palm tree and lay up to 300 eggs. Grub-like larvae (see Figure 8.2.7b in Chapter 8) feed on soft tissues inside the host plant, producing long tunnels up to $1 \mathrm{~m}$ inside the trunk. Pupation takes place at the base of the palm. Completion of the life-cycle takes four months. Feeding activity of larvae can completely destroy palms. The diurnal adults search for new palms and can fly distances up to $1 \mathrm{~km}$. Long-distance dispersal happens via infested palm trees. Host plants are different palm tree species. According to EUDecision 2007/365/EC, susceptible host plants, other than fruit and seeds, having a diameter of the stem at the base of over $5 \mathrm{~cm}$ are Areca catechu, Arenga pinnata, Borassus flaellifer, Calamus merillii, Caryota maxima, C. cumingii, Cocos nucifera, Corypha gebanga, C. elata, Elaeis guineensis, Livistonia decipiens, Metroxylon sagu, Oreodoxa regia, Phoenix canariensis, P. dactylifera, P. theophrasti, P. sylvestris, Sabal umbraculifera, Trachycarpus fortunei and Washingtonia spp. The weevil was also found in Agave americana, Brahea armata, Butia capitata, Howea firsteriana and Saccharum officinarum.

Native habitat (EUNIS code): I- Regularly or recently cultivated agricultural, horticultural and domestic habitats.

Habitat occupied in invaded range (EUNIS code): I- Regularly or recently cultivated agricultural, horticultural and domestic habitats; X24- Domestic gardens of city and town centres; X25- Domestic gardens of villages and urban peripheries.

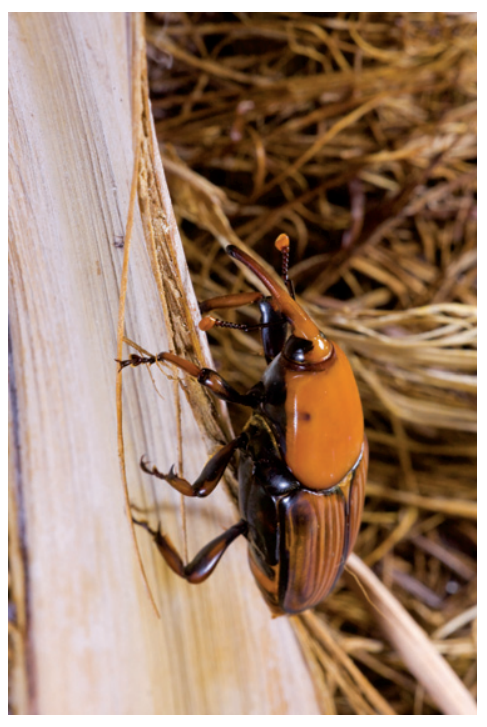




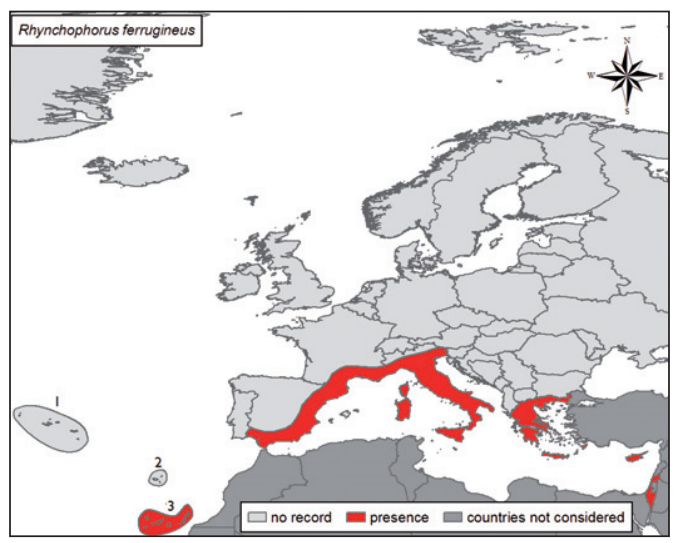

Native range: South(east)-Asia

Introduced range: $R$. ferrugineus has been introduced in most of Mediterranean countries and islands of Europe (Map). Since its first discovery in Spain (Andalucía and Valenciana, 1994) it colonized Italy (2004, incl. Sardegna, Sicilia), the Canary Islands (2005), Mallorca (2006), France (incl. Corsica), Greece, Cyprus (2006), Malta, Portugal (2007), Albania (2009) and Ceuta (2009). It also occurs in the Eastern Mediterranean region (Turkey, Syria, Israel, Jordan, Egypt) and North Africa (Morocco). Also introduced to Oceania (Australia?, Papua New Guinea, Solomon Islands), China, the Near and Middle East, and the Caribbean (Netherlands Antilles).

Pathways: Probably ornamental trade of palm trees

Impact and management: Symptoms are visible only late after colonization of the beetle and usually palms do not recover when symptoms become visible (see Figure 8.2.7c in Chapter 8). Early detection is difficult, as symptoms of infested palms remain unnoticed for several years. EU-Decision 2007/365/EU requires phytosanitary certificates for palm imports and eradication measures at infested areas. Imported palms needs to be kept in quarantine for inspection. This also is recommended for another Rhynchophorus species, $R$. palmarum, listed by EPPO as A1 species, not yet introduced to Europe, but presenting a similar phytosanitary risk to palms. Infected palms must be cut and burned or buried deeply. IPM employs pheromone traps to monitor and collect beetles. Removal of offshoots, which are preferred oviposition sites, is not recommended, because wounds attract females to oviposit. Also pruning of palm leaves should be carried out in winter, as pruning attracts beetles and facilitates egg laying. It is estimated that more than 30.000 palm trees have been destroyed in Spain within three years.

\section{Selected references}

Barranco P, de la Pena J, Cabello T (1996) El picudo rojo de las palmeras, Rhynchophorus ferrugineus (Olivier), nueva plaga en Europa (Col., Curculionidae). Phytoma-Espana 76: 36-40. Faleiro JR (2006) A review on the issues and management of red palm weevil Rhynchophorus ferrugineus (Coleoptera: Rhynchophoridae) in coconut and date palm during the last one hundred years. International Journal of Tropical Insect Science 26: 135-154.

Liu G, Peng ZQ, Fu YG (2002) Research advances on the red palm weevil Rhynchophorus ferrugineus. Journal of Tropical Agricultural Science 22: 73-77. 


\title{
14.17 - Megaplatypus mutatus (Chapuis, 1865) - The grand forest borer (Coleoptera, Curculionidae, Platypodinae)
}

\author{
Massimo Faccoli
}

Description and biological cycle: Adult females $8-9 \mathrm{~mm}$ long, males slightly smaller (7.5 $\mathrm{mm}$ ). Body brown above and reddish-yellow below, with reddish tarsi and antennae (Photo). Elytrae of males with sulcate* striae and characteristic spiniform processes on the declivity*; female elytral declivity rounded and without processes. Mature larvae about $7.2 \mathrm{~mm}$ long. $M$. mutatus bores $3 \mathrm{~mm}$-wide holes in the trunk, approximately $4 \mathrm{~m}$ above ground level. Adults excavate long and sinuous galleries that become covered by the black mycelium of symbiotic fungi, which nourish larval instars. Unlike other ambrosia beetles, $M$. mutatus attacks standing and vigorous trees. The stem attack does not kill the plant immediately, and the same tree may be re-infested several times by subsequent generations. $M$. mutatus infests mainly poplars (Populus spp.), willows (Salix spp.) and important fruit trees species such as apples (Malus spp.), walnuts (Juglans spp.) and avocados (Persea spp.). The species has been recorded also on Acer, Citrus, Eucalyptus, Fraxinus, Laurus nobilis, Magnolia grandiflora, Platanus, Prunus, Quercus, Robinia pseudacacia, Tilia and Ulmus.

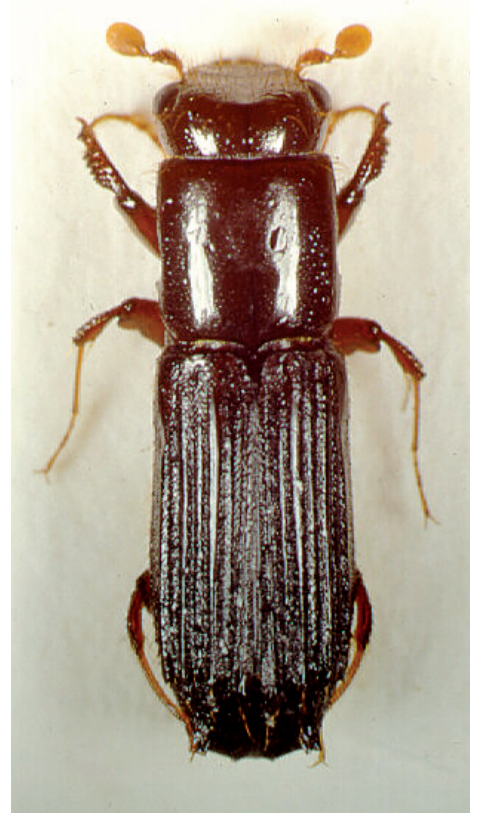

Credit: G. Allegro, CRA- Istituto di Sperimentazione per la Pioppicoltura, Casale Monferrato, eppo.org 


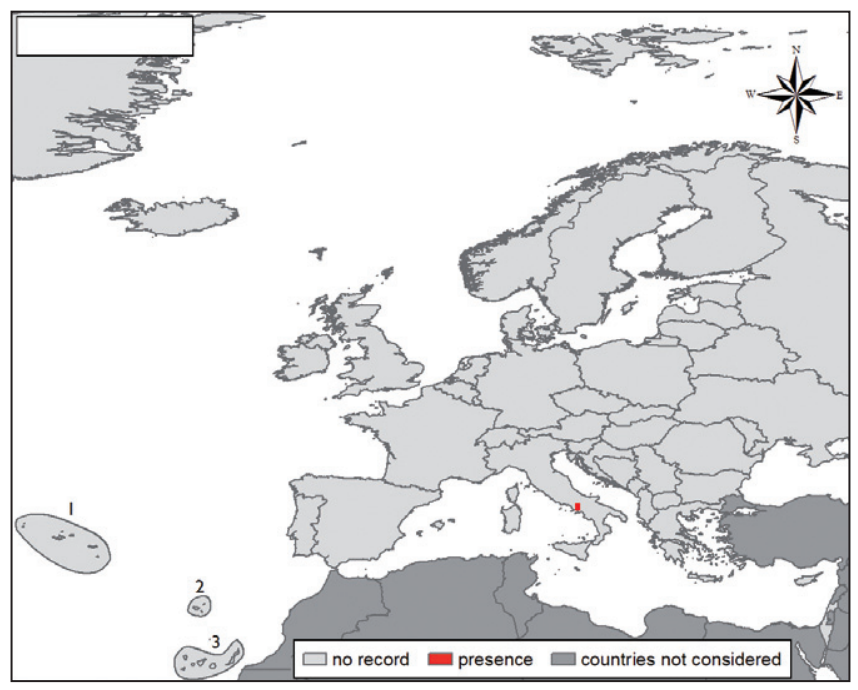

Native habitat (EUNIS code): G1 - Broadleaved deciduous woodland; G2 - Broadleaved evergreen woodland.

Habitat occupied in invaded range (EUNIS code): G1 - Broadleaved deciduous woodland; I2 - Cultivated areas of gardens and parks.

Native range: subtropical and tropical areas of South America. The weevil has extended its range into temperate regions, reaching as far south as Neuquén in Argentinean Patagonia.

Introduced range: recently introduced and acclimatized in the Napoli region, Italy (2000) (Map). Adult flight can ensure species dispersal over short distances.

Pathways: Man-mediated long-distance dispersal is possible by international trade of infested woody plants and woody materials.

Impact and management: $M$. mutatus represents a threat for many woody species widely cultivated in Europe for commercial or ornamental purpose. It is a primary pest in commercial poplar plantations, especially those of $P$. deltoides. In Italy, damage has been recorded also on fruit trees (Corylus avellana, Prunus cerasus, Pyrus communis and Malus domestica). The damage is caused by adults, which bore large gallery systems into living host-trees. The galleries and associated fungi degrade the lumber and weaken the tree stems, which often then break during windstorms. As most of the life cycle is accomplished within wood tissues, this species is difficult to detect and to control, although some chemicals are available. Recent applications of the mating disruption technique are giving promising results.

\section{Selected references}

Tremblay E, Espinosa B, Mancini D, Caprio G (2000) Un coleottero proveniente dal Sudamerica minaccia i pioppi. L'informatore Agrario 48: 89-90. 


\subsection{8 - Gnathotrichus materiarius (Fitch, 1858) - American Utilizable Wood Bark Beetle (Coleoptera, Curculionidae, Scolytinae)}

\section{Massimo Faccoli}

Description and biological cycle: Small species, 3.2-3.5 mm long, with a cylindrical, narrow and elongated body (Photo). Elytra dark reddish, generally smooth with only few short bristles on the declivity. Pronotum black and very fine punctured, except at the front where there are several granules. Head blackish and smooth, antennae with funicle*5-segmented and club with two round sutures. Anterior coxae fused. This weevil is polyphagous on conifer trees, in Europe being recorded on Pinus, Abies, Picea, Larix and Pseudotsuga. Gnathotrichus materiarius is an ambrosia beetle excavating timber galleries $1 \mathrm{~mm}$ in diameter and $10-15 \mathrm{~cm}$ long. The galleries host the black fungus Endomycopsis fasciculata Batra, which nourishes the larvae. In Central Europe, the adults fly between April and the middle of June, but it is possible that a second flight takes place at the end of the summer. The species is monogamous, but males are very rare. Mature larvae or young adults overwinter in their galleries.

Native habitat (EUNIS code): G3- Coniferous forests.

Habitat occupied in invaded range (EUNIS code): G3- Coniferous forests.

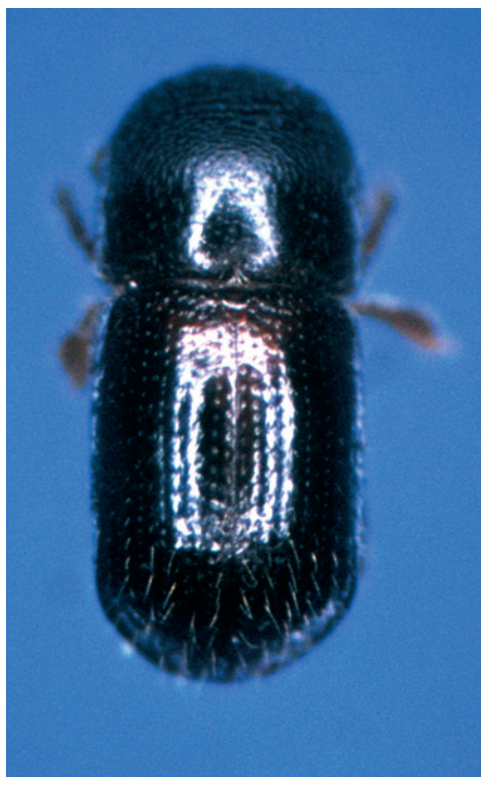

Credit: Louis-Michel Nageilesen 


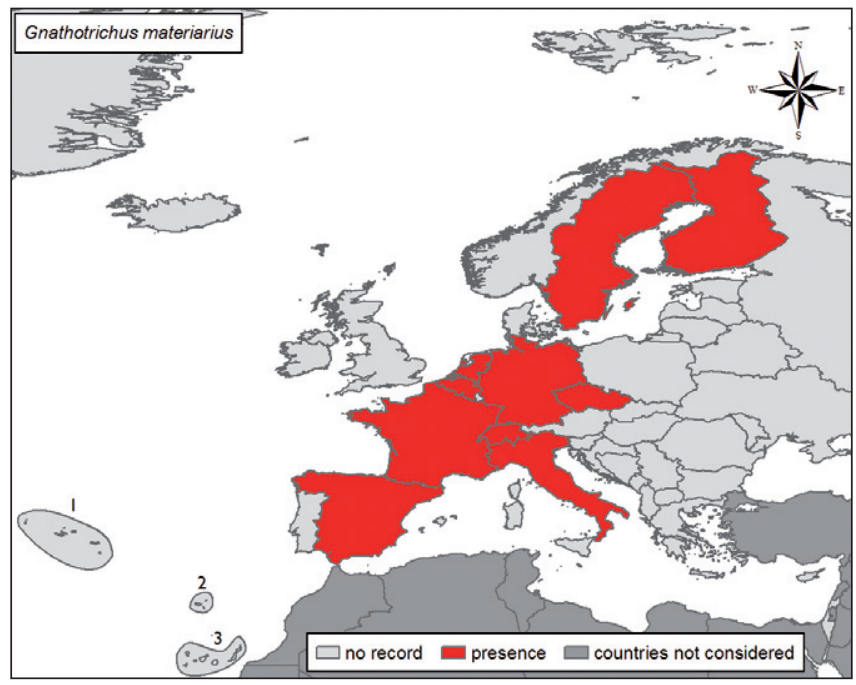

Native range: North America

Introduced range: Since its first discovery in 1933 in France, this weevil has invaded a large part of Central, Western, Central and Northern Europe (Map). Man-mediated longdistance dispersal is possible by infested wood movement.

Pathways: Trade of trees or timber.

Impact and management: This species may disturb forest ecosystems by direct/indirect competition with native xylophagous insects. Typically a secondary species, recorded only on trees already felled or killed by other bark beetles. However, infestations reduce timber value because of damage from adult galleries and black discolouration caused by associated ambrosia fungi. Control is usually not required. Population monitoring may be based on visual detection of damage and by pheromone traps. Mechanical control may consist in the destruction of infested trees by chipping or burning. Natural enemies (parasitoid insects, entomopathogenic nematodes, fungi or bacteria) for possible biological control are under investigation but not yet being used. Chemical control has limited effect because the insects live deep within wood.

\section{Selected references}

Balachowsky A (1949) Coléoptères Scolytides. Faune de France 50. Paris: Librairie de la faculté des sciences. 320 pp.

Faccoli M (1998) The North American Gnathotrichus materiarius (Fitch) (Coleoptera Scolytidae): an ambrosia beetle new to Italy. Redia 81: 151-154.

Valkama H, Martikainen P, Raty M (1997) First record of North American ambrosia beetle Gnathotrichus materiarius (Fitch) (Coleoptera, scolytidae) in Finland - a new potential forest pest? Entomologica fennica 8: 193-195. 


\subsection{9 - Phloeosinus rudis Blandford, Japanese Thuja Bark Beetle (Coleoptera, Curculionidae, Scolytinae)}

\section{Leen Moraal}

Description and biological cycle: Scolitid beetle, dark-brown, length of adults $2.5-3.0 \mathrm{~mm}$ (Photo). Females bore into the trunks of shrubs and trees weakened by drought and other stress factors. They excavate $2-3$ armed egg galleries with a length varying from $5-16 \mathrm{~cm}$. Feeding activity of the larvae kills the hosts. The diameter of emergence holes varies from 1.1-1.9 $\mathrm{mm}$. The beetle overwinters, with a small percentage of adults, since the larval stage predominates. This weevil produces one generation per year. The photo shows an adult and also larval galleries in a 60-year-old tree of Thuja occidentalis. Host plants are Thuja, Chamaecyparis and Juniperus.

Native habitat (EUNIS code): G3- Coniferous forests.

Habitat occupied in invaded range (EUNIS code): X24- Domestic gardens of city and town centres; X25- Domestic gardens of villages and urban peripheries.

Native range: Japan

Introduced range: First found outside Japan in Southern France near St-Tropez, in June 1940, in dying branches of a Thuja japonica plantation. However, the beetle has not been

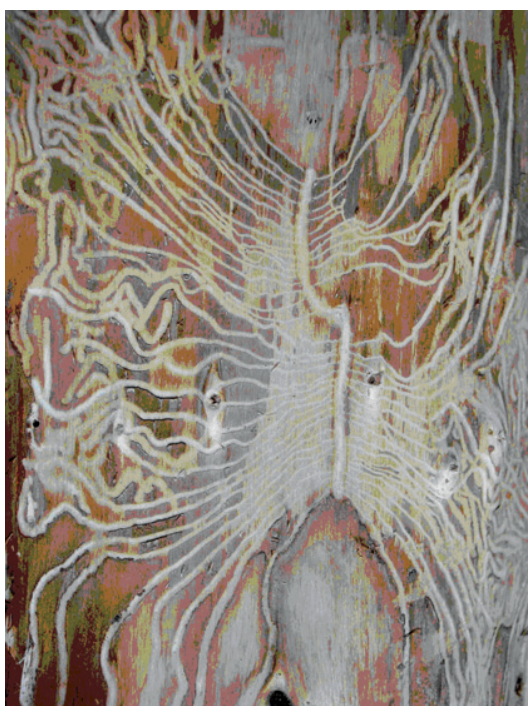

Credit: Leen Moraal 


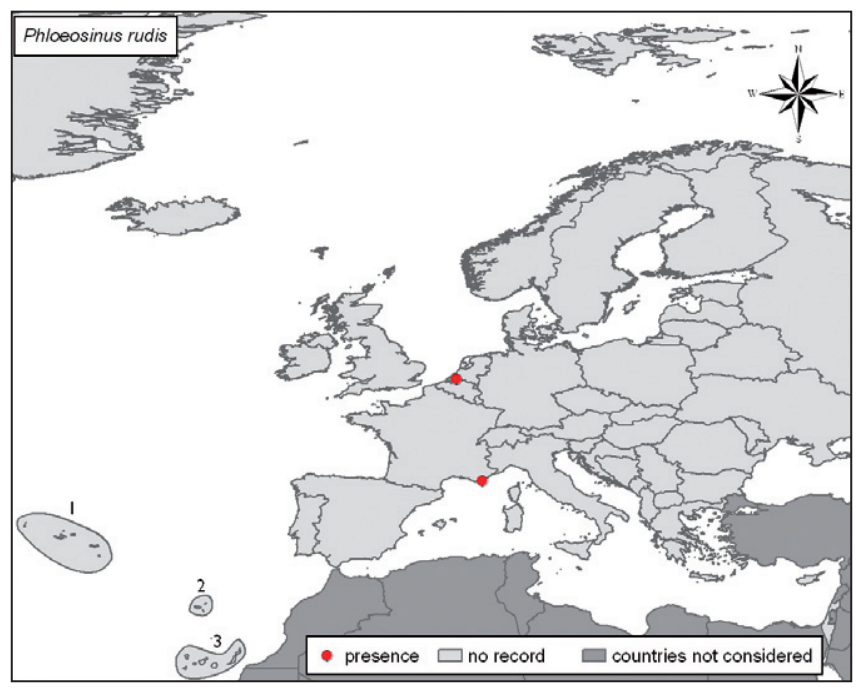

recorded in France since then. During the summer of 2004, hundreds of conifers, old solitary trees as well complete hedges, died in several cities around Rotterdam. Between 2004-2008, few infestations were found. This is probably due to the return to normal summer precipitation of the years following 2004, leading to more vigorous plants with less infestation. Because small beetle populations may survive in weakened trees, a new drought period may result in a new weevil population build-up.

Pathways: All Dutch locations were situated within $30 \mathrm{~km}$ of the harbour of Rotterdam. It is suspected that $P$. rudis may have escaped from imported material from this harbour, but this could not be verified. The beetle was intercepted several times in the USA in wood off-cuts integrated in steel products from Asia, but there are no records of establishment in the USA.

Impact and management: Symptoms become visible in summer when the needles turn brown and the hosts are dying. Removal and destruction of larval infested plants is recommended to control populations.

\section{Selected references}

Balachowsky A (1949) Coléoptères scolytides. Faune de France 50. Paris : Lechevallier, 124-126. Hoffmann A (1942) Description d 'un genre nouveau et observations diverses sur plusieurs espèces de Scolytidae (Col.) de faune Francaise. Bulletin de la Société Entomologique de France 47: 72-74.

Pfeffer A (1995) Zentral- und westpaläarktische Borken- und Kernkäfer (Coleoptera: Scolytidae, Platypididae). Pro Entomologia, Naturhistorisches Museum, Basel: 69. 


\title{
14.20 - Xylosandrus crassiusculus (Motschulsky, 1866) - Granulate Ambrosia Beetle (Coleoptera, Curculionidae, Scolytinae)
}

\author{
Massimo Faccoli
}

Description and biological cycle: The adult is about $2.1-2.9 \mathrm{~mm}$ long, with stout body, elytra 1.15 times longer than pronotum and reddish (Photo left-female). Elytra with vestiture of long setae in irregular rows. Elytral declivity dull, with dense, numerous, uniformly distributed granules, allowing easy distinction from other Xylosandrus species occurring in Europe. Male smaller than female, rare. Xylosandrus crassiusculus is an ambrosia beetle developing within the wood and feeding on the mycelium of ambrosia fungi. Mated females bore small chambers and lay eggs in groups. Larvae develop together feeding on the fungus growing on the chamber walls. During gallery formation, the female compacts and pushes out the frass, which extends from the entrance hole forming a long, easily visible cylinder (Photo right). The adults usually overwinter in galleries at the base of the trees. $X$. crassiusculus develops in Europe on Carob tree, Ceratonia siliqua, but is highly polyphagous in the native range on Pinus spp. and broadleaved trees.

Native habitat (EUNIS code): G - Woodland and forest habitats and other wooded land

Habitat occupied in invaded range (EUNIS code): G2 - Broadleaved evergreen woodland; J100- Greenhouses.

Native range: Paleotropical species (Africa and Asia)

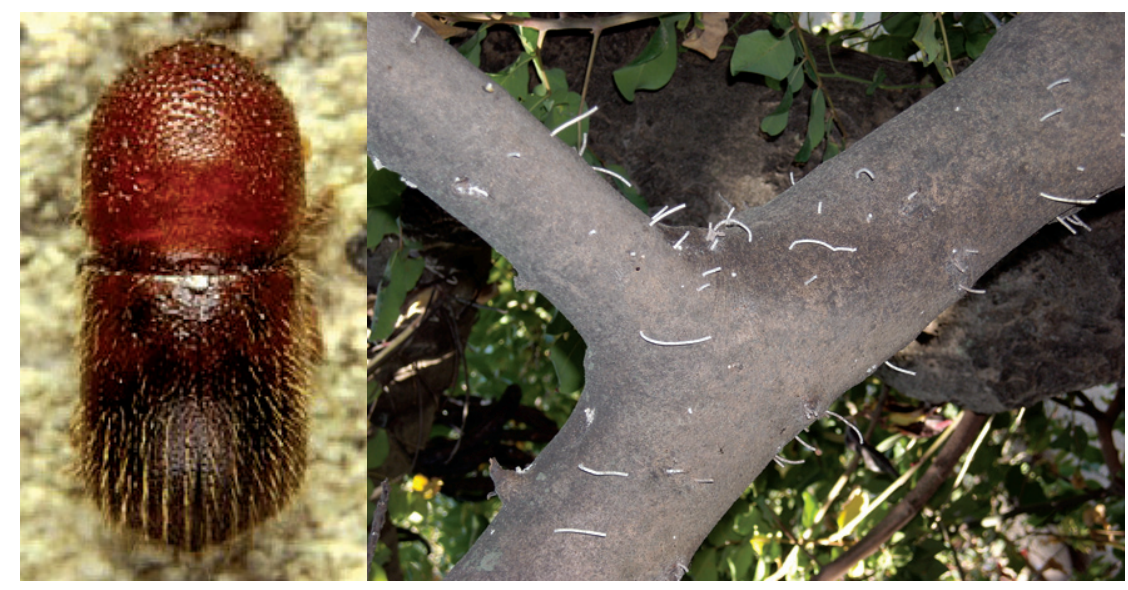

Credit: meta.arsia.toscana.it (left), EPPO (right) 


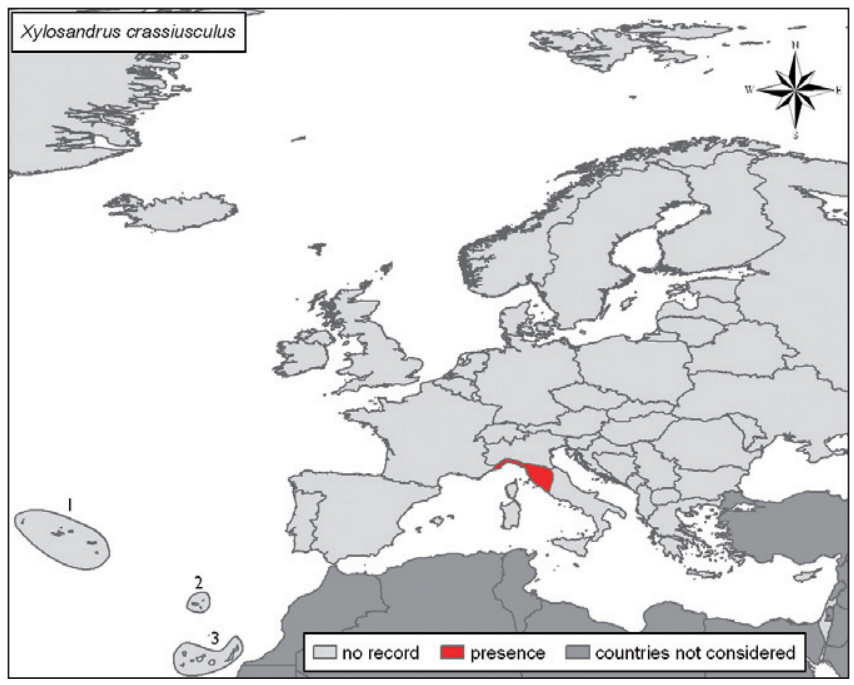

Introduced range: since 2003 recorded in Europe (Italy: Tuscany and Liguria- Map), probably introduced with infested trees or timber. Also introduced in North America.

Pathways: Long-distance dispersal is possible by trade of infested timber.

Impact and management: This beetle may disturb forest ecosystems by direct and indirect competition with native xylophagous insects. It may attack trees from about $2 \mathrm{~cm}$ stem diameter upwards in both stressed plants and is found in harvested timber. At high population density, $X$. crassiusculus may attack and kill healthy trees causing significant economic loss. Infested timber has reduced value because of adult galleries and black discolouration due to associated ambrosia fungi. Population monitoring and control may be performed using pheromone traps and the trees themselves as traps. Mechanical control is effected by destruction of infested trees via chipping or burning. Chemical control has limited effect because the insects develop deep within wood.

Prevention is achieved via timber debarking before insect infestation and by keeping trees in good physiological condition.

\section{Selected references}

Pennacchio F, Roversi PF, Francardi V, Gatti E (2003) Xylosandrus crassiusculus (Motschulsky) a bark beetle new to Europe. Redia 86: 77-80. 


\title{
14.21 - Xylosandrus germanus (Blandford, 1894) (= Xyleborus germanus) - Black stem borer \\ (Coleoptera, Curculionidae, Scolytinae)
}

\author{
Massimo Faccoli
}

Description and biological cycle: Ambrosia beetle, 2.0-2.4 mm long, with shiny black elytra, surface of elytral declivity* shining, anterior margin of pronotum with 8-10 asperities* (Photo). This species is highly polyphagous on conifers and broadleaves, attacking a wide range of both living plants and timber. Adults fly during early to mid May, infesting timber of the lower part of the trunk of stressed trees. By specialized organs (tegumental mycangia*), during tunnel excavation, the female introduces the pathogenic fungus Ambrosiella hartigii (Batra) (= Monilia candida Hartig) into the host plants. The associated fungus causes cankered areas in the stem and treetop as well as branch dieback and suckering. During gallery formation, frass ejected by the female often protrudes as a long and conspicuous cylinder. Although in Europe generally considered to be monovoltine, two generations per year have been observed in Germany and Italy. Adults of $X$. germanus usually overwinter in galleries at the base of attacked trees. Hosts in the invaded range include both broadleaved species (Fagus, Castanea, Buxus, Ficus, Carpinus, Quercus and Juglans) and conifers (Picea and Pinus).

Native habitat (EUNIS code): G - Woodland and forest habitats and other wooded land.

Habitat occupied in invaded range (EUNIS code): G - Woodland and forest habitats and other wooded land.

Native range: Asia.

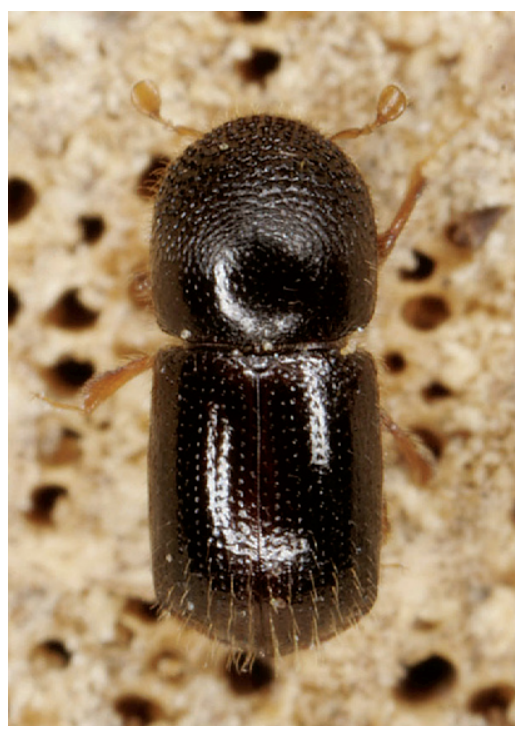

Credit: Christoph Benisch, kerbtier.de 


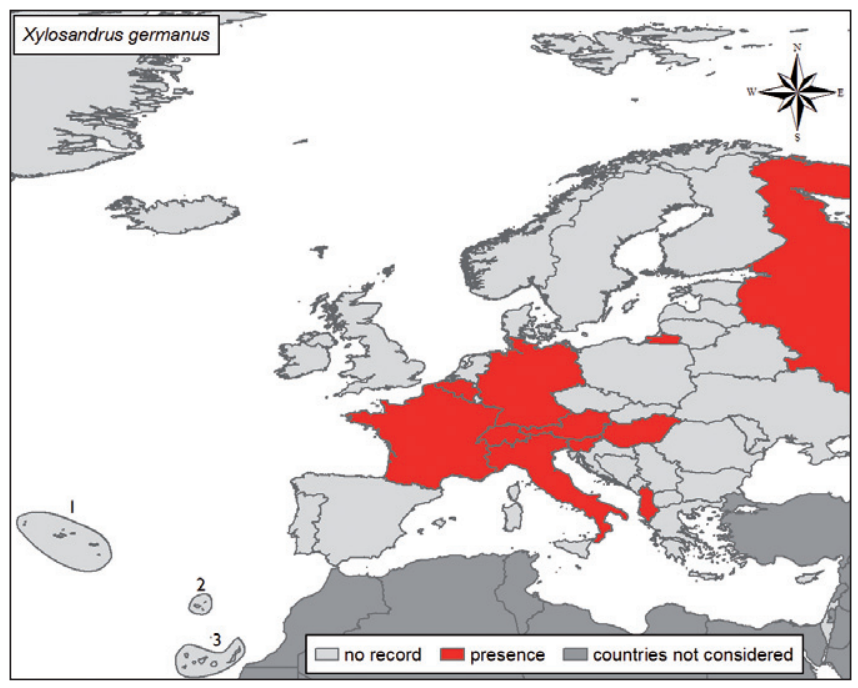

Introduced range: First detected in Germany in 1950. Then, the weevil spread in most countries of Western and Central Europe as far as the European part of Russia (Map). Increasing frequency of interceptions has been reported during recent years in Europe. Also introduced in North America.

Pathways: Man-mediated long-distance dispersal is possible by movement of infested timber.

Impact and management: This weevil may disturb forest ecosystems by direct/indirect competition with native xylophagous insects. Such secondary* species have been recorded on stressed living trees or harvested timber. Water stress is one of the main causes inducing stem colonization of living trees. Infestation kills the host plant and reduces timber value because of damage from adult galleries and black discolouration due to associated ambrosia fungi. Population monitoring and control may be performed by pheromone traps and trees used themselves as traps. Mechanical control involves destruction of infested trees by chipping or burning. Chemical control is of limited effect because the insects live deep within wood. Damage reduction and prevention may rely on timber debarking before insect infestation and keeping trees in good physiological condition.

\section{Selected references}

Bruge H (1995) Xylosandrus germanus (Blandford, 1894) [Belg. sp.nov.] (Coleoptera Scolytidae). Bulletin et annales de la Société Royale Belge d'Entomologie 131: 249-264.

Graf E, Manser P (1996) Der Schwarze Nutzholzborkenkäfer, Xylosandrus germanus. Wald und Holz 2: 24-27.

Henin JM, Versteirt V (2004) Abundance and distribution of Xylosandrus germanus (Blandford 1894) (Coleoptera, Scolytidae) in Belgium: new observations and an attempt to outline its range. Journal of Pest Science 77: 57-63. 


\title{
14.22 - Tribolium confusum (Du Val, 1868) - Confused flour beetle (Coleoptera, Tenebrionidae)
}

\author{
Katalin Tuba and Ferenc Lakatos
}

Description and biological cycle: Small beetle species. Adults are 2.6-4.4 mm long, shiny, reddish-brown or chestnut-brown (Photo). The first antennal segments are obscured by the forehead. Antennae widen from the 5-6th segment. The head and the pronotum are finely dotted. The elytra are patterned with lines also consisting of fine dots. Adults may live more than three years. Eggs are $0.4 \mathrm{~mm}$ long and white. Larvae have six larval stages. Their length is 6-7 $\mathrm{mm}$ in the final larval stage. Young larvae are white, aging yellowish. The body of larvae is cylindrical and slight hairy. On the ninth abdominal segment there are two hook-like projections. Larvae have three pairs of legs. The length of the yellowish brown pupa is 3-4 mm. There are three or five generations per year. Development time is about 40-45 days under optimal circumstances depending on sex, temperature, humidity and nutrition. Each female lays a total of 450-900 eggs. Females lay eggs one by one and thus the oviposition period is long. Eggs adhere well to the crop surface with a glue-like material. Larvae live for 3-4 weeks chewing crops. The pupa stage lasts a maximum of two weeks. The adults mature after 2-7 days. Adults overwinter in stores.

Native habitat (EUNIS code): I- Regularly or recently cultivated agricultural, horticultural and domestic habitats; J- Constructed, industrial and other artificial habitats.

Habitat occupied in invaded range (EUNIS code): J-Constructed, industrial and other artificial habitats.

Native range: Africa.

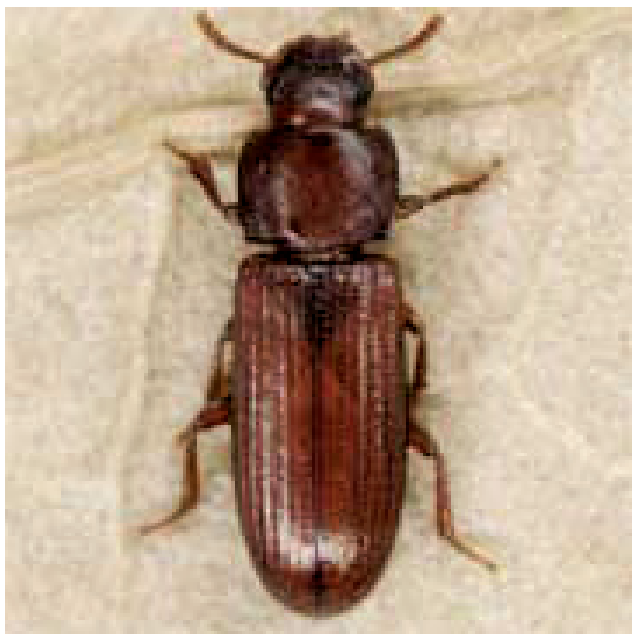

Credit: Christoph Benisch, kerbtier.de 


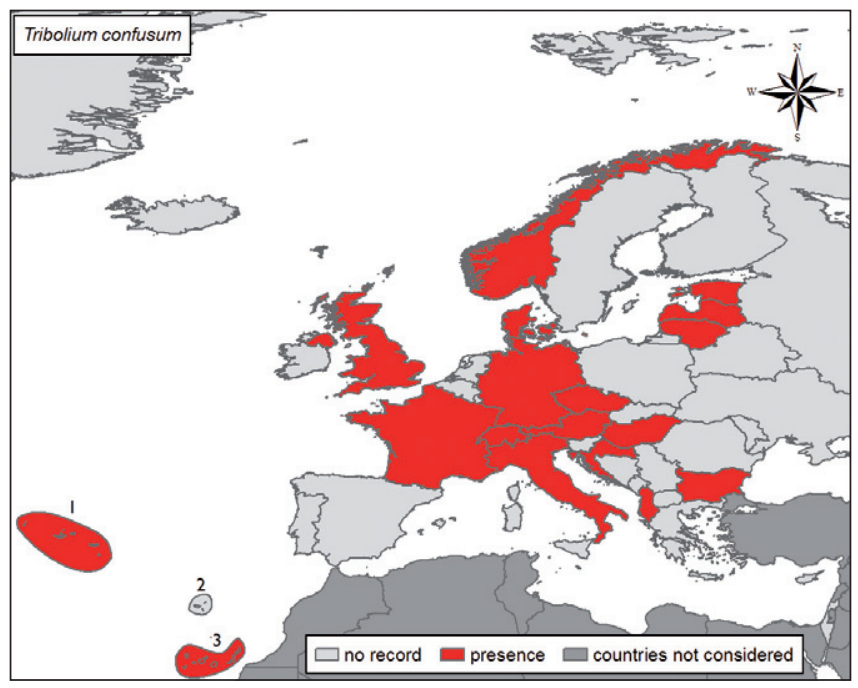

Introduced range: All over the world. Tribolium confusum can withstand cooler climates than red flour beetle ( $T$. castaneum), which is found in more temperate areas. The confused flour beetle moved into Europe from America at the end of the $19^{\text {th }}$ century. Its range limit in Europe is now Scandinavia (Map).

Pathways: The wide geographical distribution of this pest is to a certain extent due to dissemination of infested stored products.

Impact and management: The confused flour beetle is one of the most important pests of the stored products in homes, groceries and granaries. This is a highly polyphagous species. Both adults and larvae cause damage, but the main pests are larvae. These attack flour, cereals, meal, crackers, pasta, cake, beans, peas, spices, dried pet food, chocolates, nuts, seeds and even dried museum specimens. Crops contaminated by larval skins, excrement and chewed residues are smelly and rendered inedible by both humans and animals. Physical and chemical as well as biological control can be used against this insect. Interestingly, cannibalistic interactions among certain life stages (eggs and pupae by adults, and eggs by larvae) constitute a natural control mechanism of confused flour beetles.

\section{Selected references}

Benoit HP, McCauley E, Post JR (1998) Testing the demographic consequences of cannibalism in Tribolium confusum. Ecology 79: 2839-2851.

Baldwin R, Fasulo TR (2003): Tribolium confusum Jacqulin du Val (Insecta: Coleoptera:

Tenebrionidae). http://www.entnemdept.ufl.edu/creatures/urban/beetles/red_flour_beetle.

htm [accessed 25 February 2010].

Jenser G, Mészáros Z, Sáringer Gy (Eds) (1998) A szántóföldi és a kertészeti növények kártevői.

Mezőgazda Kiadó Budapest: 177-178. 


\title{
14.23 - Liriomyza huidobrensis (Blanchard, 1926) - Serpentine leaf miner (Diptera, Agromyzidae)
}

\author{
Alain Roques
}

Description and biological cycle: Small fly, adult 1.3-2.3 mm long, compact-bodied, greyishblack (Photo left); maggot appears headless, up to $3.3 \mathrm{~mm}$ in length, yellow-orange at maturity. Larvae are leaf miners on a wide range of hosts, especially economically important vegetables and ornamental plants in both glasshouses and outdoors. Adult flight range is limited. Longrange dispersal (eggs, larvae) occurs with human-transported infested plant material, including cut flowers. The vase-life of chrysanthemums is sufficient to allow completion of the life-cycle. Under laboratory conditions, a female lays about 100-130 eggs but up to 250 eggs have been observed. Eggs are laid into the leaf tissue. Larvae tunnel within the leaf tissue forming characteristic mines (Photo right-mines with a puparium), then cut a semi-circular opening in the tissue and drop to the soil to pupate. The life cycle can be as short as $14 \mathrm{~d}$ at $30{ }^{\circ} \mathrm{C}$ or as long as $64 \mathrm{~d}$ at $14^{\circ} \mathrm{C}$. Generations follow in quick succession as long as the growing conditions of the host plant provide suitable food. Optimal temperatures for feeding and egg laying range between $21-32^{\circ} \mathrm{C}$. Egg-laying is reduced at temperatures below $10{ }^{\circ} \mathrm{C}$. All stages are killed within a few weeks by cold storage at $0{ }^{\circ} \mathrm{C}$ and above $40{ }^{\circ} \mathrm{C}$.

Native habitat (EUNIS code): F5- semi-arid and subtropical habitats

Habitat occupied in invaded range (EUNIS code): I1- Arable land and market gardens; I2- Cultivated areas of gardens and parks; J100- glasshouses.

Native range: South America.

Introduced range: First recorded from France in 1989, spreading with imported ornamentals; now outdoors in southern Europe (including Sicily and the Canary islands- Map), but mainly a glasshouse pest in northern Europe. Also introduced in Central America, most of Asia (China, Taiwan, India, Thailand, Singapore, Indonesia), Asia Minor, Africa (Kenya), and Indian Ocean (Reunion, Mauritius, Seychelles).

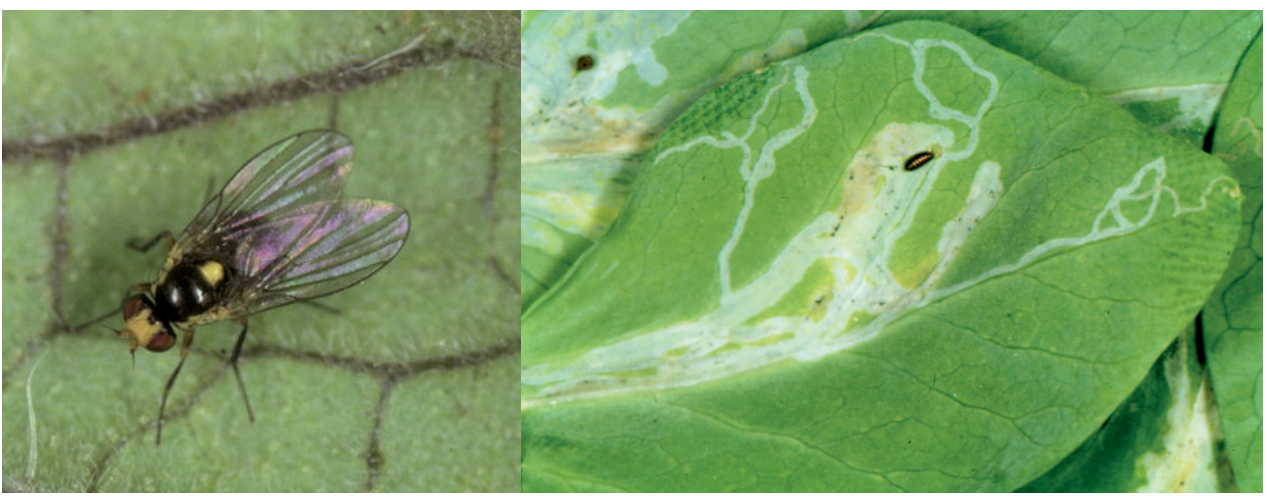

Credit: Jean-Yves Rasplus (left), Michel Martinez (right) 


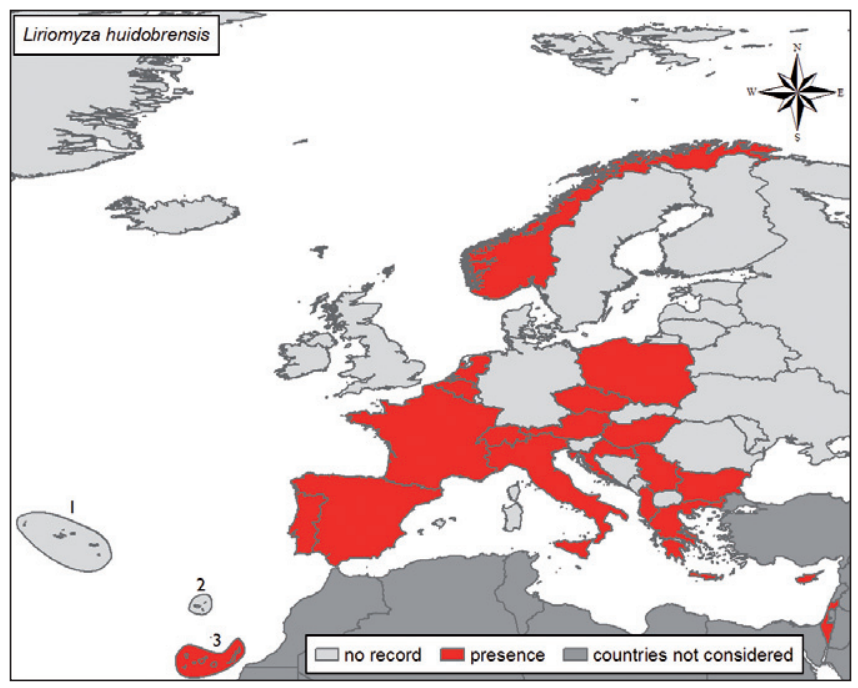

Pathways: Passive transport with plant trade including vegetables, cut flowers and nursery stock.

Impact and management: A serious pest for the floricultural industry, where leaf-miner damage directly affects the marketable portion, or in vegetable crops where the leaves are sold as the edible part. Sticky traps can be used to monitor adult flies. Crop rotation is an effective pest management tool, as is avoiding varieties more highly susceptible to leaf-miner infestations in glasshouses. There is little information about the leaf-miner tolerance of field vegetables. In this case, cultivation of crop debris or removal of infected plant material is recommended. L. huidobrensis adults are resistant to conventional insecticides. At present, the only effective insecticides are translaminar insecticides (abamectin, cyromazine, neem and spinosad), which penetrate the leaves to affect the leaf-miner larvae. Parasitoid wasps (e.g., Diglyphus isaea and Dacnusa sibirica)are available for control in glasshouse crops. These parasitoids will not be effective for vegetables growing in the field. However, there may be natural parasites present that can reduce the population.

\section{Selected references}

Maseti A, Luchetti A, Mantovani B, Burgio G (2006) Polymerase Chain Reaction-restriction fragment length polymorphism assays to distinguish Liriomyza huidobrensis (Diptera: Agromyzidae) from associated species lettuce cropping systems in Italy. Journal of Economic Entomology 99(4): 1268-1272.

Phalip M, Martinez M (1994) Liriomyza huidobrensis : ses plantes hôtes et les confusions possibles avec d' autres espèces. PHM Rev Hort 353: 24-28.

Scheffer SJ, Lewis ML (2001) Two nuclear genes confirm mitochondrial evidence of cryptic species within Liriomyza huidobrensis (Diptera: Agromyzidae). Annals of the Entomological Society of America 94: 648-653. 


\subsection{4 - Liriomyza trifolii (Burgess, 1880) - Chrysanthemum leaf miner (Diptera, Agromyzidae)}

\section{Ejup Çota}

Description and biological cycle: The adult fly is small, greyish-black, compact-bodied, 1-1.3 $\mathrm{mm}$ in length, up to $1.7 \mathrm{~mm}$ in the female, with wings $1.3-1.7 \mathrm{~mm}$ (Photo left). Eggs are $0.2-0.3 \mathrm{~mm} \times 0.10-0.15 \mathrm{~mm}$, off-white and slightly translucent. The larva is a "headless" maggot up to $3 \mathrm{~mm}$ in length when fully grown. First instar larvae are colourless on hatching, turning pale yellow-orange. Later instars are yellow-orange. Female flies puncture the leaves of the host plants causing wounds, which serve as sites for feeding or oviposition. Eggs are inserted just below the leaf surface. Hatching occurs 2-5 days later and the three larval instars make serpentine mines in the leaves (Photo right). The larvae develop in a few days and leave the mine to pupate in the soil or in crop debris. There are many generations per year. The life cycle from oviposition to adult emergence can be as short as $12 \mathrm{~d}$ at $35^{\circ} \mathrm{C}$ or as long as $54 \mathrm{~d}$ at $15^{\circ} \mathrm{C}$. Adult flies are capable of limited flight.

Native habitat (EUNIS code): I- Regularly or recently cultivated agricultural, horticultural and domestic habitats.

Habitat occupied in invaded range (EUNIS code): I1 - Arable land and market gardens; I2- Cultivated areas of gardens and parks; J100- glasshouses.

Native range: North America.

Introduced range: First detected in France in 1976, now occurring in most European countries (Map) but unable to overwinter outdoors in Northern and Central Europe, and found only in glasshouses in these regions.

Pathways: Trade of plant material, e.g. cut flowers, plants for planting out, and vegetables.

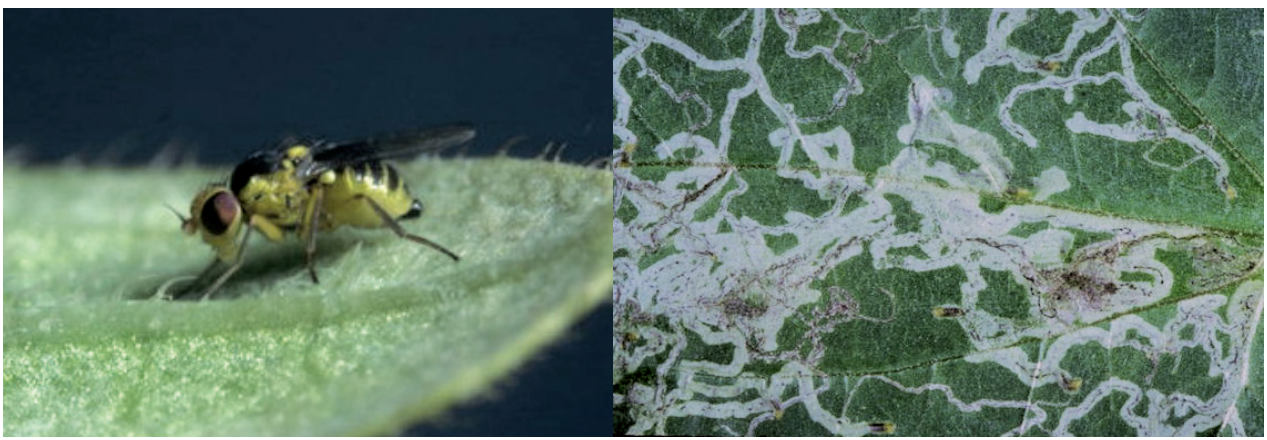

Credit: Rémy Coutin/ OPIE (left), Jean-Pierre Lyon/ INRA (right) 


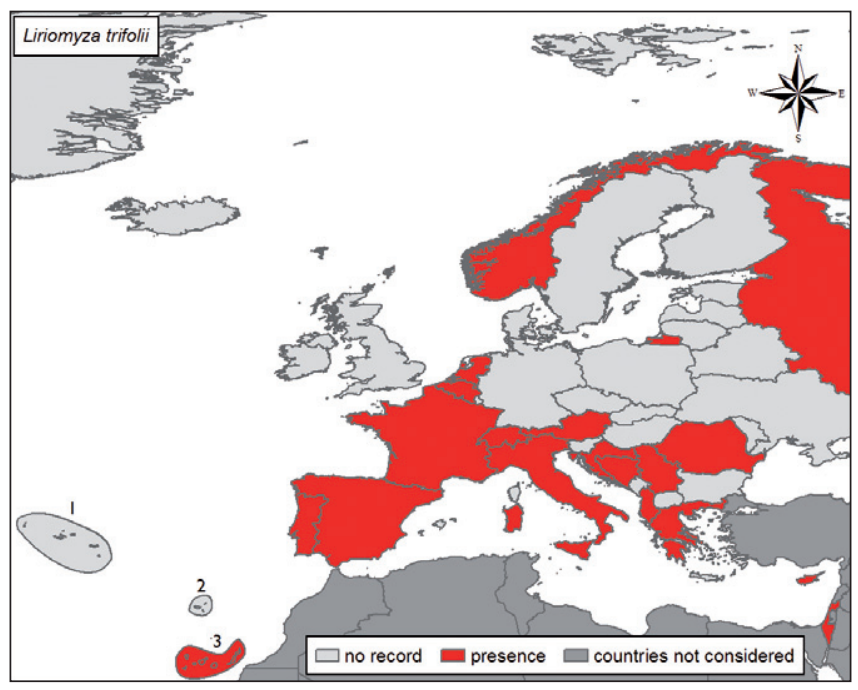

Impact and management: Feeding and oviposition punctures of adults affect the value of ornamentals. However, damage is mainly done by larvae mining into the leaves and petioles, which reduces photosynthesis and may result in leaf drop. Mines are typically serpentine, tightly coiled and of irregular shape. Liriomyza trifolii is a major pest of various Asteraceae worldwide, both in outdoor crops and in glasshouses. It is particularly serious on Chrysanthemum, but also celery, onion, tomato, Gerbera, etc. In addition to the impact on yield, mines and feeding punctures also reduce the commercial value of ornamental plants and vegetables. Control by insecticides is feasible, although resistance is a problem. In glasshouses, the leaf miner is best controlled using natural enemies, such as parasitoids or nematodes. In field vegetables, cultivation of crop debris or removal of infected plant material is recommended. To prevent the introduction and establishment of $L$. trifolii and other leaf miner species, it is recommended that propagating material of susceptible plants from countries where the pests occur should be inspected at least every month for three months and verified free from the pests.

\section{Selected references}

Aguilar J d', Martínez M (1979) Sur la présence en France de Liriomyza trifolii Burgess. Bulletin de la Société Entomologique de France 84, 143-146.

Arzone A (1979) L'agromizide neartico Liriomyza trifolii (Burgess) nuovo nemico di Gerbera in Italia. Informatore Fitopatologico 29: 3-6.

Sher RB, Parrella MP (1996) Integrated biological control of leafminers, Liriomyza trifolii, on greenhouse chrysanthemums. Proceedings of the meeting Integrated control in glasshouses, held in Vienna, Austria, 20-25 May 1996. Bulletin OILB/SROP 1996: 147-150. 


\title{
14.25 - Dasineura gleditchiae (Osten Sacken, 1866) - Honey locust pod midge (Diptera, Cecidomyiidae)
}

\author{
Ljubodrag Mihajlović and Milka M. Glavendekić
}

Description and biological cycle: Approximately 2.0-3.0 mm long, antennae, long, moniliform* $^{*}$ antennae with 12 flagellar segments, compound eyes holoptic* with no ocelli. Thorax grey with two prominent black longitudinal stripes. First tarsomere considerably shorter than second segment out of five and tarsal claws with large, basal teeth. Mouthparts reduced. Unsculptured eggs elongate-ovoid and opaque-white, turning opaque-red. Larvae elongate and dorso-ventrally flattened with pebble-like integument, varying from white to orange. First-third larval instars 0.57-2.44 mm long. Pupae approximately $2.43 \mathrm{~mm}$ long, obtect* with horn-like spines located at antennal base. Pupae sexually dimorphic; females with red and males with grey abdomen. D. gleditchiae is monophagous, living on Gleditsia triacanthos L. Generation time ranges from 21-30 days with several overlapping generations per year, overwintering as pupae or late instar larvae in cocoons in the soil. First appearance of the gall midge is in April, with males appearing first. Females deposit eggs on new foliage along the rachis or on edges of developing leaf buds. Eggs usualy hatch in two days. Young larvae crawl along the leaf to begin feeding. Only one larva is required to induce galling of the leaf. Leaf galls may be folded, partially pod-like, or the entire leaf may form a pod (Photo). The leaf gall dies and drops once the larvae pupate and emerge.

Native habitat (EUNIS code): G1 - Broadleaved deciduous woodland; G5 - Lines of trees, small anthropogenic woodlands, recently felled woodland, early-stage woodland and coppice.

Habitat occupied in invaded range (EUNIS code): FA- Hedgerows; I2 - Cultivated areas of gardens and parks and landscape; X24- Domestic gardens of city and town centres.

Native range: Nearctic species widespread in North America.

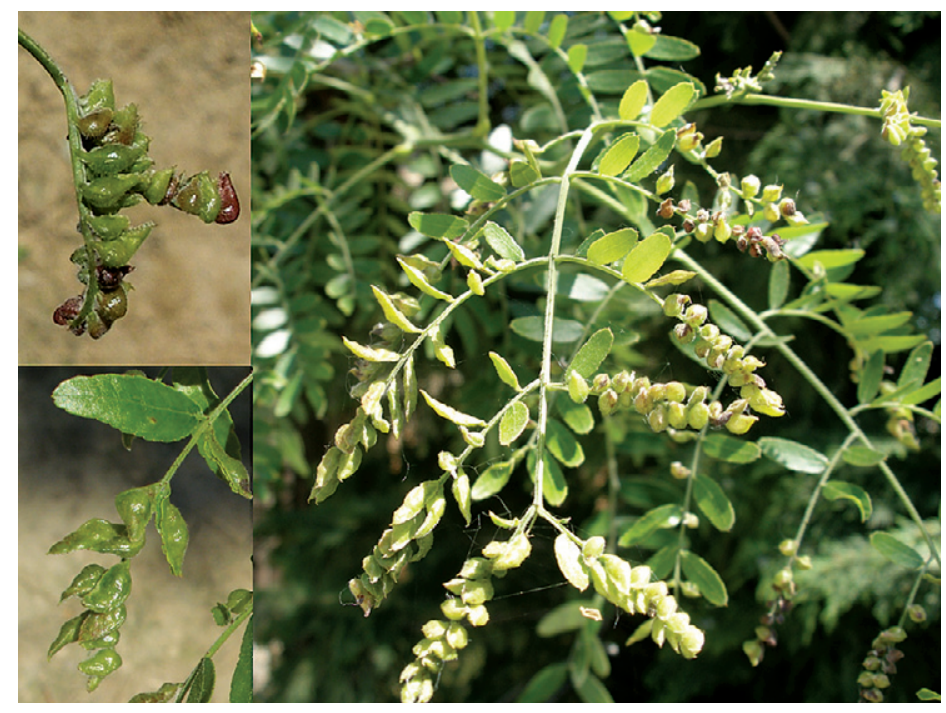

Credit: Ljubomir Mihajlović 


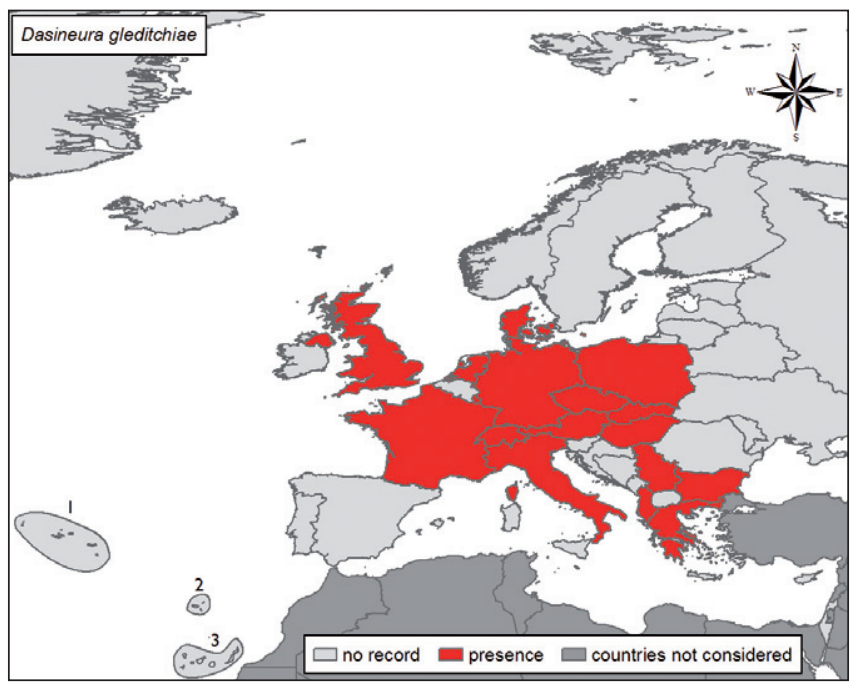

Introduced range: First discovered in Europe in 1980 in the Netherlands. Since that time, galls of this gall midge were recorded in several other countries of Central and Southern Europe (Map). Also introduced in Turkey.

Pathways: The main mode of introduction and spread is passive transport of coccons in soil with nursery stock or directly with infested young plants. Dispersal on a local scale is realized by active flight of adults and favoured by wind.

Impact and management: Honey locust pod gall midge is a major pest of honey locust. Feeding by midge larvae causes leaflets of new growth to form pod like galls in which the larvae pupate. After the adult midge emerges from the pod, the leaf tissue dies and drops prematurely. Much of new growth can be affected, reducing the aestetic quality of trees in nurseries and landscapes. Monitoring of honey locust trees in nursery and landscape sites should begin in early spring and throughout the growing season, noting the appearance of eggs deposited on buds and new foliage by overwintering and first generation adults. Clusters of red midge eggs on honey locust buds can be observed with a hand lens. Effective chemical control is achieved by using various organophosphates, pyrethroids, carbamates and neonicotinoids. Oil applications in a narrow date-range targeting the first two egg depositions in April should facilitate midge population suppression. Biological control can be achieved using the Nearctic parasitoid Zatropis catalpae Craw. (Hymenoptera., Pteromalidae).

\section{Selected references}

Bolchi Serini G, Volonté L (1985) Dasineura gleditchiae (Osten Sacken), Cecidomide nuovo per l'Italia (Diptera, Cecidomyiidae). Bollettino di Zoologia agraria e di Bachicoltura Ser. II 18: 185-189.

Dauphin P (1991) Sur la présence en France de Dasineura gleditchiae (Diptera, Cecidomyiidae), gallicole sur Gleditsia triacanthos (Fabacées, Caesalpinoidae). Bulletin de la Société Linnéenne de Bordeaux 19: 126.

Estal P, Soria S, Vinuela E (1998) Nota de la presencia en España de Dasineura gleditchiae (Osten Sacken), sobre acacia de tres espinas. Boletín de Sanidad Vegetal Plagas 24: 225-230. 


\title{
14.26 - Obolodiplosis robiniae (Haldeman, 1847) - Black locust gall midge (Cecidomyiidae, Diptera)
}

\author{
Marcela Skuhravá
}

Description and biological cycle: Adult small, body 2.5-3.2 mm long, reddish-brown, with long antennae, hairy wings and long densely haired legs (Photo left). Larvae at first whitish, fully grown larvae pale yellow, with typical sclerotized organ - spatula sternalis* - on ventral surface of prothoracic segments. Larvae are monophagous, inducing galls on leaves of black locust (Robinia pseudoacacia), a Fabaceae tree originating in North America. Larvae are gregarious and develop in galls formed of downwards rolled leaflet margins (Photo right). Several overlapping generations develop during one vegetative season. Pupation takes place in galls. In autumn, fully grown larvae leave galls and drop to the soil, where they hibernate till the spring of the next year. The population density is high.

Native habitat (EUNIS code): G1 - broadleaved and deciduous woodland, native in north-eastern part of USA.

Habitat occupied in invaded range (EUNIS code): G5- Lines of trees, small anthropogenic woodlands, recently felled woodland, early-stage woodland and coppice; I2 - Cultivated areas of gardens and parks; FB - Shrub plantations

Native range: North America.

Introduced range: Galls appeared suddendly in north-eastern Italy at Paese, Treviso Province in 2003, but the source of the infestation remains unknown. In 2004, the galls were found in northern Italy and in the Czech Republic at high infestation levels and in Slovenia. In the course of four years, the species spread very quickly in several countries of Europe and at present it occupies a large distribution area from England to Ukraine (Doneck) and from northern Germany to southern Italy $(\mathrm{Map})$. The galls of $O$. robiniae appeared also suddendly in Korea and Japan in 2002. O. robiniae has a strong tendency to spread and can quickly become abundant in newly colonized areas.

Pathways: Black locust gall midge probably arrived in Europe with plant materials imported from the USA. The source of its rapid spread in Europe may be international traffic along

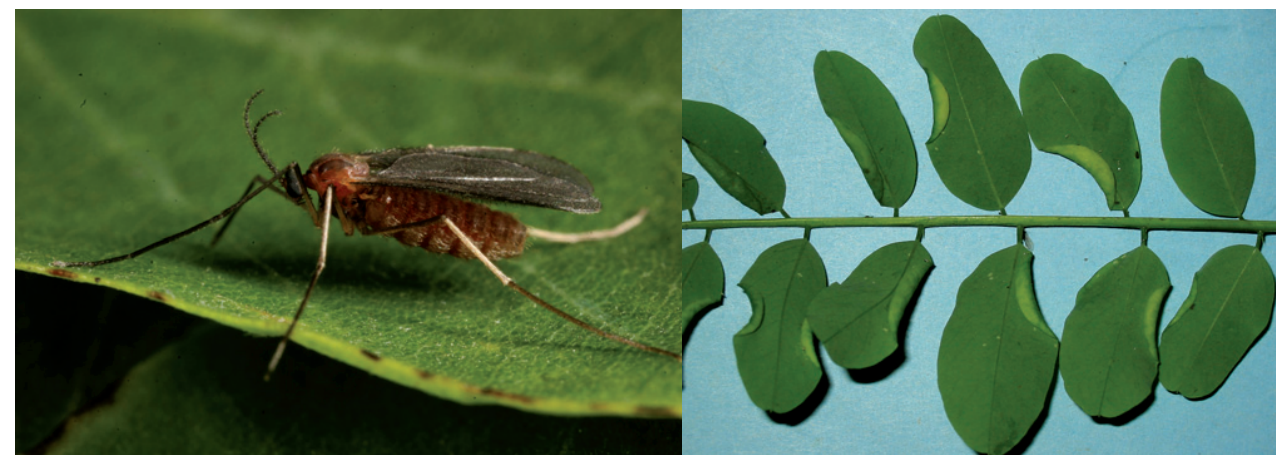

Credit: György Csóka (left), Vaclav Skuhravý (right) 


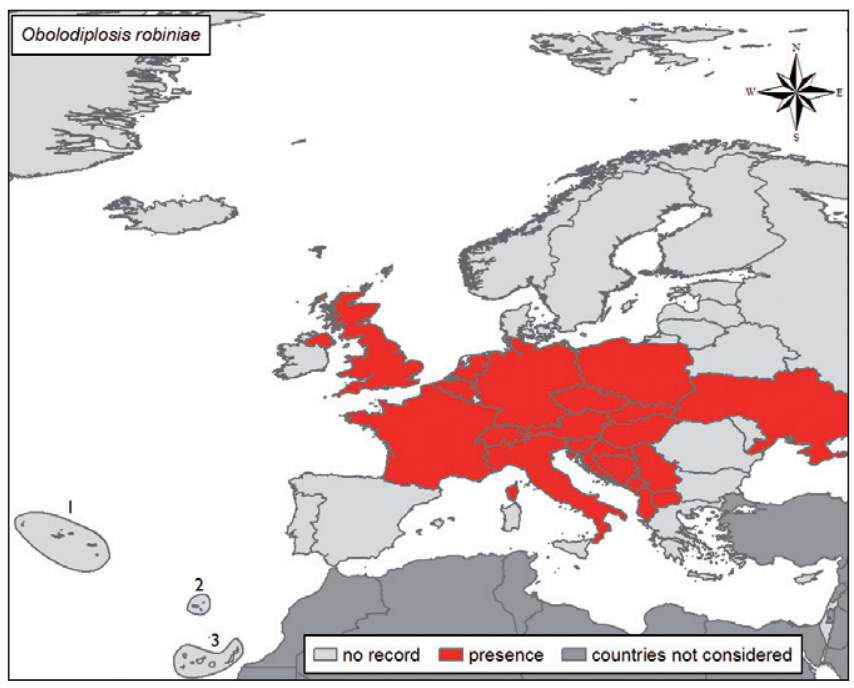

roads. Larvae drop from the galls and may be transported in vehicles over large distances. Adult midges, due to their small size, may be transferred by the wind. Young seedlings in forest nurseries or nurseries raising ornamental shrubs and trees may be transported to new places hidden in their indistinct galls. High fecundity of females and exponential growth of populations in the course of one vegetative season has contributed to the rapid spread of this species in Europe.

Impact and management: Black locust is a tree with continual growth during the vegetative season. Nearly all leaflets of young shoots may be attacked by gall midges. Attacked leaflets dry up and fall off precociously after larval exit. The aesthetic value of damaged trees and shrubs is reduced. Monitoring may be achieved by visual detection of galls on trees and shrubs. Until now, insecticides have not been used to reduce populations. Natural enemies have been found in Europe, but surprisingly not in North America where O. robiniae is native. The endoparasitoid Platygaster robiniae (Hymenoptera: Proctotrupoidea: Platygastridae) has potential to reduce the gall midge population future biological control. The fungus Beauveria bassiana (Entomophthoraceae) was found during a study of gall midge larvae. Mechanical control is effected by cutting off infested parts with galls and burning is also recommended.

\section{Selected references}

Bathon H (2007) Die Robinien-Gallmücke Obolodiplosis robiniae (Haldeman) (Diptera: Cecidomyiidae) in Deutschland. Hessische Faunistische Briefe 26: 51-55.

Duso C, Fontana P, Tirello P (2005) Diffusione in Italia e in Europa di Obolodiplosis robiniae (Haldeman), dittero cecidomiide neartici dannoso a Robinia pseudoacacia. Informatore fitopatologico 5: 30-33.

Glavendekić M, Roques A, Mihajlović L (2009) An ALARM Case study: The Rapid Colonization of an Introduced Tree, Black Locust by an Invasive North-American Midge and Its Parasitoids. In: Settele J et al. (Eds) Atlas of Biodiversity Risks - from Europe to the globe, from stories to maps. Pensoft, Sofia \& Moscow (www.pensoftonline.net/alarm-atlas-info, in press. 


\title{
14.27 - Aedes albopictus (Skuse, 1894) - Asian tiger mosquito (Diptera, Culicidae)
}

\author{
Alain Roques
}

Description and biological cycle: Mosquito with black adult body and conspicuous white stripes on body and legs. Males (Photo left) have plumose antennae, whereas females have sparse short hairs (Photo right-female on human skin). Females are active during the day and are bloodfeeders on vertebrates, including humans. Adult flight range is limited (200-400 m). Long-distance dispersal (eggs, larvae) mediated by human activity. Average fecundity of 150-250 eggs, up to 5 generations per year. Eggs are laid in the water in tree holes and domestic containers. Breeding populations are present from March to November; overwintering at egg stage. Eggs are resistant to desiccation and cold. Larvae require only $6 \mathrm{~mm}$ of water depth to complete life cycle. Areas at risk have mean winter temperatures higher than $0{ }^{\circ} \mathrm{C}$, at least $500 \mathrm{~mm}$ precipitation and a warm-month mean temperature higher than $20^{\circ} \mathrm{C}$.

Native habitat (EUNIS code): G- Woodland and forest habitats and other wooded land; J6: Waste deposits. Typically breeds in tree holes and others small water collections surrounded by vegetation but also in peri-domestic containers filled with water.

Habitat occupied in invaded range (EUNIS code): J6: Waste deposits. Mostly opportunistic container breeder capable of using any type of artificial water container, especially discarded tyres, but also saucers under flower pots, bird baths, tin cans and plastic buckets. It can establish in non-urbanised areas lacking artificial containers.

Native range: Southeast Asia.

Introduced range: Continuous spread all over the world since the late 1970s. First recorded in Europe in 1979 in Albania. Then, accelerated expansion was observed in Southern Europe since 2000, mostly along the Mediterranean Coast (Map). Some spots were detected in northwestern Europe, where it was tentatively eradicated. Also introduced in the Middle East, Africa, the Caribbean and North and South America.

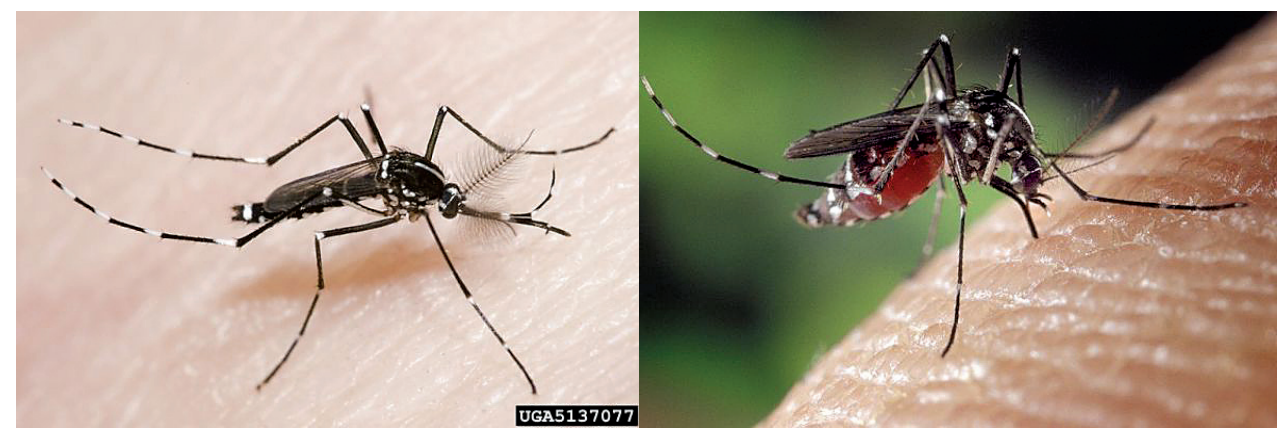

Credit: Susan Ellis, Bugwood.org (left), James Gathany, Centres for Disease Control and Prevention, USA (right) 


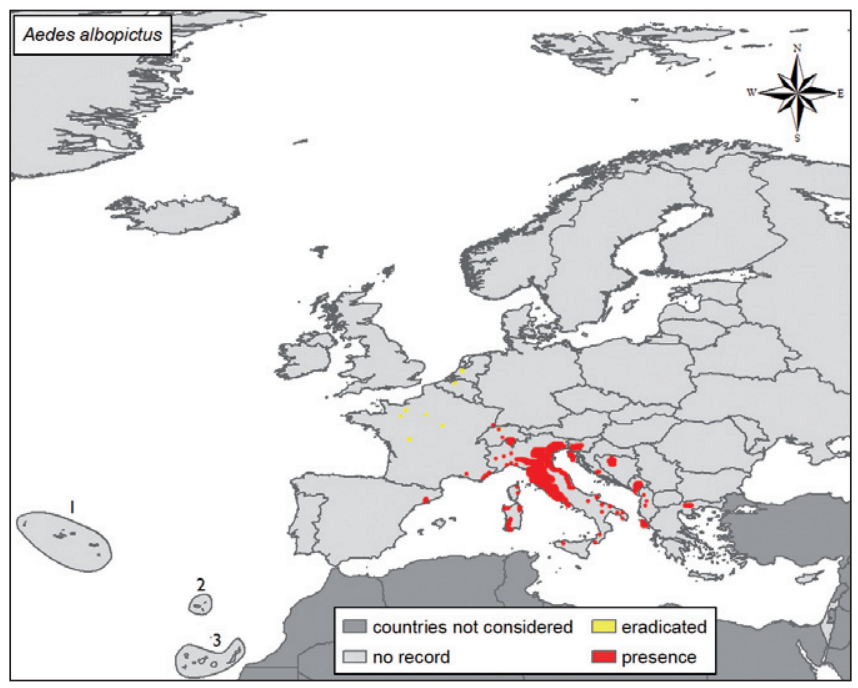

Pathways: Stowaway. Passive transport as dormant eggs via the international tire trade (due to the rainwater retained in the tires when stored outside), aircraft, boats and terrestrial vehicles and as larvae in "lucky bamboo" Dracaena spp., and other phytotelmata* shipped with standing water.

Impact and management: Interspecific larval competition causes displacement of native mosquito species. Considerable health risk and economic costs result from the biting nuisance and the potential as vector for at least 22 arboviruses (including dengue, chikungunya, Ross River, West Nile virus, Japanese encephalitis, eastern equine encephalitis), avian plasmodia and dog heartworm filariasis Dirofilaria. For monitoring, ovitraps are used: artificial breeding containers (e.g., tyres) baited with frozen $\mathrm{CO} 2$ from dry ice. Mechanical control: removal of discarded tyres. All sources of standing water should be emptied every $3 \mathrm{~d}$ in areas at risk; water reserves that cannot be dumped can be treated with a spoonful of vegetable oil to suffocate mosquito larvae. To control larvae, spray water with derivates of Bacillus thuringiensis israelensis or larval growth inhibitors (diflubenzuron). To control adults, spray with deltamethrine. To control adults, spray with deltamethrine. Cyclopoid copepod predators (e.g., Macrocyclops, Mesocyclops) can be used for container-breeding larvae, and fishes and dragonflies in other situations.

\section{Selected references}

Eritja R, Escosa R, Lucientes J, Marquès E, Roiz D, Ruiz S (2005) Worldwide invasion of vector mosquitoes: present European distribution and challenges for Spain. Biological Invasions 7: 87-97.

Gratz NG (2004) Critical review of the vector status of Aedes albopictus. Medical and Veterinary Entomology 18: 215-227.

Urbanelli S, Bellini R, Carrieri M, Sallicandro P, Celli G (2000) Population structure of Aedes albopictus (Skuse): the mosquito which is colonizing Mediterranean countries. Heredity 84: 331-337. 


\title{
14.28 - Ceratitis capitata (Wiedemann, 1824) - Mediterranean fruit fly (Diptera, Tephritidae)
}

\author{
Alain Roques
}

Description and biological cycle: Small fly, 4-5 mm long. Adults with yellowish body, brown abdomen and legs, and yellow-banded wings (Photo). Larva 6-8 mm long at maturity, elongate, cream coloured, and of cylindrical maggot shape. Phytophagous on a wide range of temperate and subtropical fruits. Adult flight range up to $20 \mathrm{~km}$ but winds can carry flying adults over longer distances; intercontinental dispersal (eggs, larvae) via infested fruits transported by humans. Before reaching sexual maturation, adults feed 6-8 d on fruit juices. Females lay up to 22 eggs per day and 300-800 eggs during lifetime, under the skin of a fruit just beginning to ripen. Under tropical conditions, overall life cycle is completed in 21-30 d. Adults may survive for up to six months.

Native habitat (EUNIS code): G- Woodland and forest habitats and other wooded land.

Habitat occupied in invaded range (EUNIS code): I- Regularly or recently cultivated agricultural, horticultural and domestic habitats; I1- Arable land and market gardens.

Native range: Tropical Eastern Africa.

Introduced range: Observed in Europe since 1873 in Italy. Present all over southern Europe (Map); regularly observed but not established in other parts of Europe; global warming may allow populations to establish at higher latitudes than at present. It has also been introduced in Africa, Middle East, Central and South America, the Caribbean, Hawaii, Australia. Eradicated in USA except Hawaii.

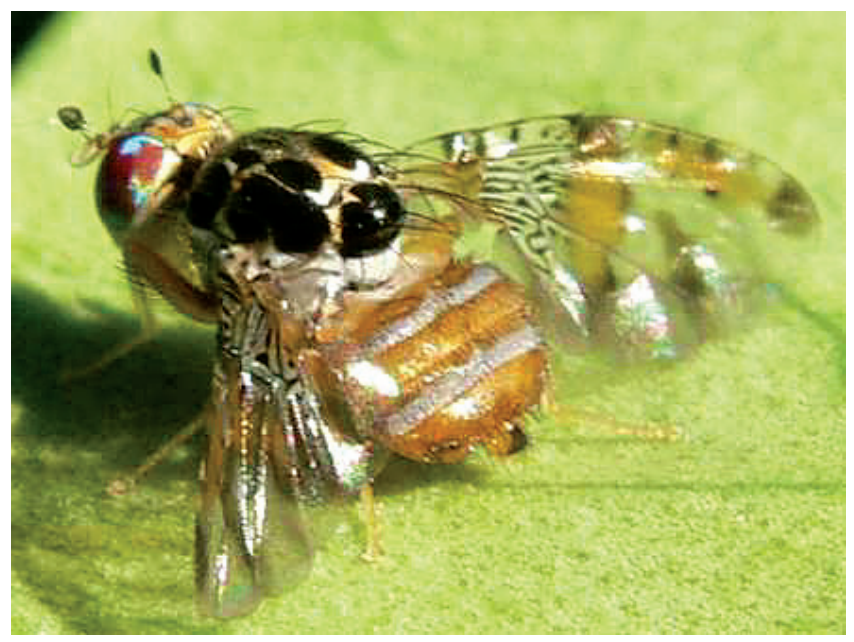




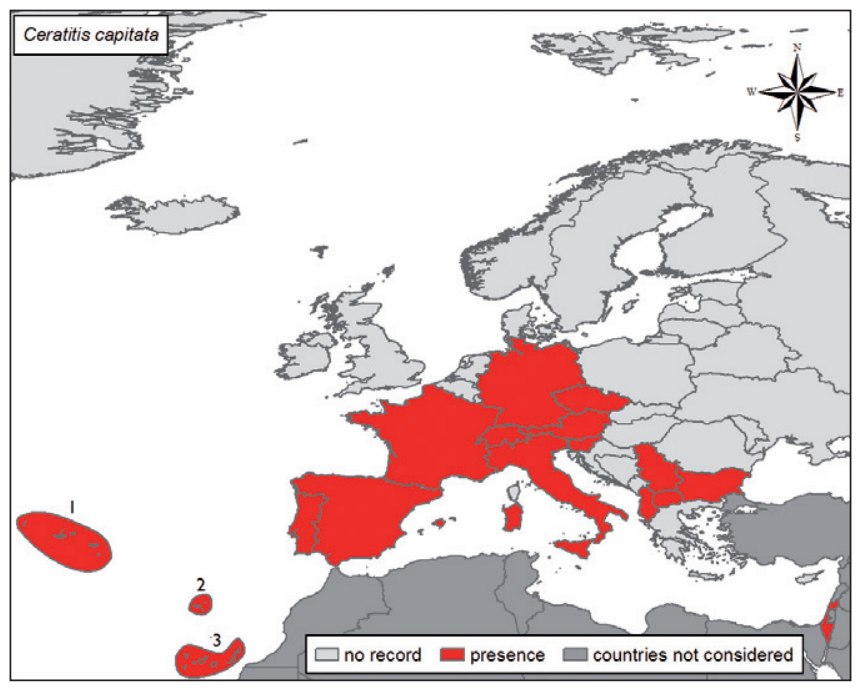

Pathways: Imported with fruit trade but also with passengers transporting infested fruits during trips.

Impact and management: Probably the most important fruit fly pest, inducing large damage in fruit crops, especially citrus fruits and peach. Fly damage results from both oviposition in fruit, feeding by the larvae, and decomposition of plant tissue by invading secondary microorganisms (bacteria, fungi) that cause fruit rot. Their presence often requires host crops to undergo quarantine treatments, other disinfestation procedures or certification of fly-free areas. The costs of such activities and phytosanitary regulatory compliance can be significant and definitely affect global trade. To ensure early detection, traps baited with chemical attractants (especially trimedlure) can be used. Larvae can be killed by soaking, freezing, cooking or pureeing infested fruits. Fruits can be bagged to prevent egg laying. Field sanitation needs to destroy all unmarketable and infested fruits; harvesting fruit weekly also reduces food sources by keeping the quantity of ripe fruit on the trees to a minimum. Chemical sprays are not completely effective. It is better to use foliage baits combining a source of protein with an insecticide to attract both males and females. Biological control involves use of sterile insects and release of parasitoids.

\section{Selected references}

Copeland RS, Wharton RA, Luke Q, De Meyer M (2002) Indigenous Hosts of Ceratitis capitata (Diptera: Tephritidae) in Kenya. Annals of the Entomological Society of America 95: 672-694.

Liebhold AM, Work TT, McCullough DG, Cavey JF (2006) Airline Baggage as a Pathway for Alien Insect Species Invading the United States. American Entomologist 52: 48-56.

Malacrida AR, Marinoni F, Torti C, et al (1998) Genetic aspects of the worldwide colonization process of Ceratitis capitata. Heredity 89: 501-507. 


\title{
14.29 - Rhagoletis completa Cresson, 1929 - Walnut husk fly (Diptera: Tephritidae)
}

\author{
Marc Kenis
}

Description and biological cycle: Adults are typical tephritid yellow-orange flies with black stripes on wings, 4-8 $\mathrm{mm}$ long (Photo left). Adults fly in summer, and can live up to 40 days. Breeds in the husks of walnuts (Juglans spp.). Eggs are laid under the skin of the host fruit and hatch after 3-7 days. Larvae feed for 2-5 weeks, usually in the mesocarp (Photo right-larva emerged from a walnut). Overwinters in its puparium in the soil. There is only one generation per year.

Native habitat (EUNIS code): G1 - Broadleaved deciduous woodlands; I- Regularly or recently cultivated agricultural, horticultural and domestic habitats.

Habitat occupied in invaded range (EUNIS code): G1 Broadleaved deciduous woodland; I1 - Arable land and market gardens. I2- Cultivated areas of gardens and parks.

Native range: North America.

Introduced range: First found in Switzerland and Italy in the 1980s, from where it spread to several European countries, including France, Germany, Slovenia and Croatia (Map). Its distribution is closely linked to that of walnut species.

Pathways: The main mode of dispersal is probably human-mediated transport through larval infested fruits. Adults can fly, but only a short distance.

Impact and management: Attacked walnut fruits are pitted by oviposition punctures around which discolouration usually occurs. Larvae usually feed on the mesocarp, but

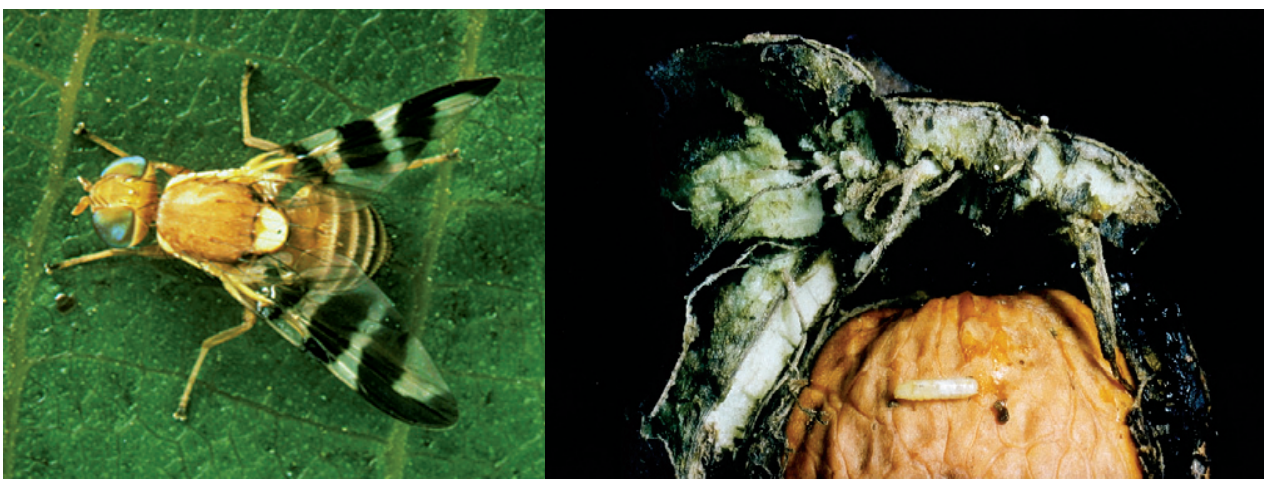

Credit: Erwin Mani, eppo.org 


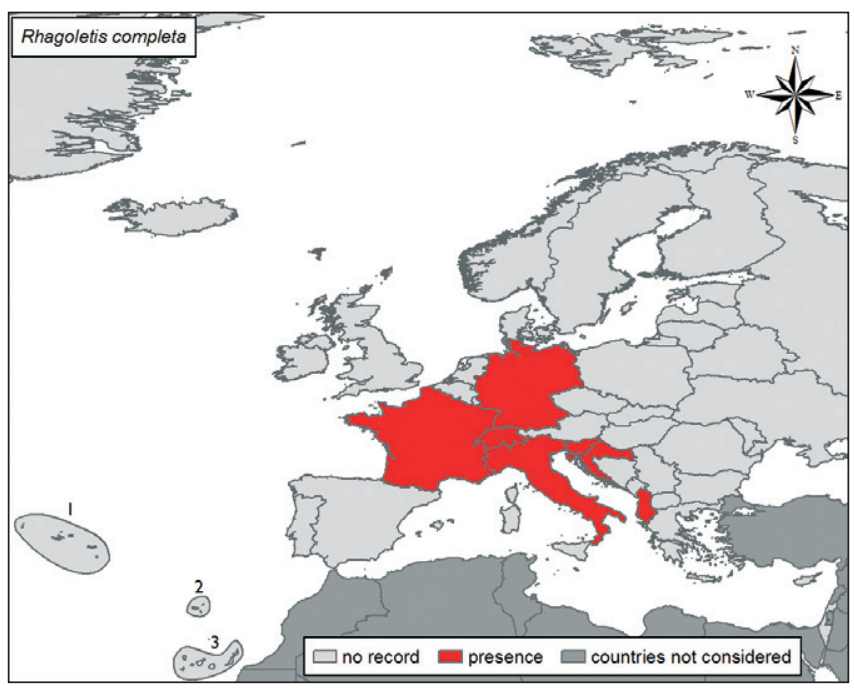

at high density, larvae also damage the pericarp and the nut itself. Walnuts attacked by the fly become unfit for sale, because of the discolouration of the nut. Walnut husk fly is a major pest of walnut in the USA. Since its introduction into Europe, populations are increasing, and severe damage has been observed, with up to $100 \%$ of harvested walnuts infested in some orchards. Various chemical treatments are effective against $R$. completa. Attacked fruits should be removed and destroyed before the larva emerges. Covering the soil under trees may prevent the larvae from entering the soil and pupating. Yellow sticky traps baited with ammonia can be used as a monitoring method, but are not efficient as a control method.

\section{Selected references}

Duso C, Lago G dal (2006) Life cycle, phenology and economic importance of the walnut husk fly Rhagoletis completa Cresson (Diptera: Tephritidae) in northern Italy. Annales de la Société Entomologique de France 42: 245-254.

Mani E, Merz B, Brunetti R, Schaub L, Jermini M, Schwaller F (1994) Zum Auftreten der beiden amerikanischen Fruchtfliegenarten Rhagoletis completa Cresson und Rhagoletis indifferens Curran in der Schweiz (Diptera: Tephritidae). Mitteilungen der Schweizerischen Entomologischen Gesellschaft 67: 177-182.

Romani M (1998) Gravi attacchi di Rhagoletis completa nei noceti lombardi. Informatore Fitopatologico 48: 13-16. 


\subsection{0 - Adelges nordmannianae (Eckstein, 1890) (= Dreyfusia nordmannianae, $=$ D. nüsslini Börner) - Silver fir woolly aphid (Hemiptera, Adelgidae)}

\section{Hans Peter Ravn}

Description and biological cycle: Winged female adult aphids (emigrants) from the primary host have a body length of 1.1-2.3 $\mathrm{mm}$ and wing span of about $4,6 \mathrm{~mm}$. They are greenish just after the moult, turning darker. Winged female adults from the secondary host (remigrants) are grey-green and have a body length of $0.8-1.2 \mathrm{~mm}$. Body length of parthenogenetic females is $0.7-1.5 \mathrm{~mm}$; they are black-brown or black-violet. The body is covered with wax-wool. The small, turtle-shaped nymphs usually have only a peripheral fringe of wax round their body. In the native range, the aphid has a two-year life cycle with sexual reproduction on a primary host, Oriental Spruce, Picea orientalis (or P. omorica), and a parthenogenetic reproduction on a secondary host, Caucasian fir, Abies nordmanniana, which is replaced by European silver fir, Abies alba, in the introduced range in Europe. On Picea orientalis, aphids induce a $6-8 \mathrm{~mm}$ gall (Photo left) growing from the short side-branches and also consisting of thickened needles. Galls are not induced on Abies species. The overwintering stage on the secondary host is $2^{\text {nd }}-3$ rd instar larvae, situated on the shoot axis of the previous year's shoot. In early spring, they develop into egg-producing females. Each female produces 110-500 eggs in a rosette-shaped heap. After hatching, young larvae will move to the new shoots and suck either on the new shoot axis or on the needles (Photo right). Some of the larvae develop into winged adults that will try to re-migrate to $P$. orientalis. Needle-feeding larvae and some shoot feeding larvae develop into females producing 10-30 eggs, from which the larvae move to the shoot axis for overwintering.

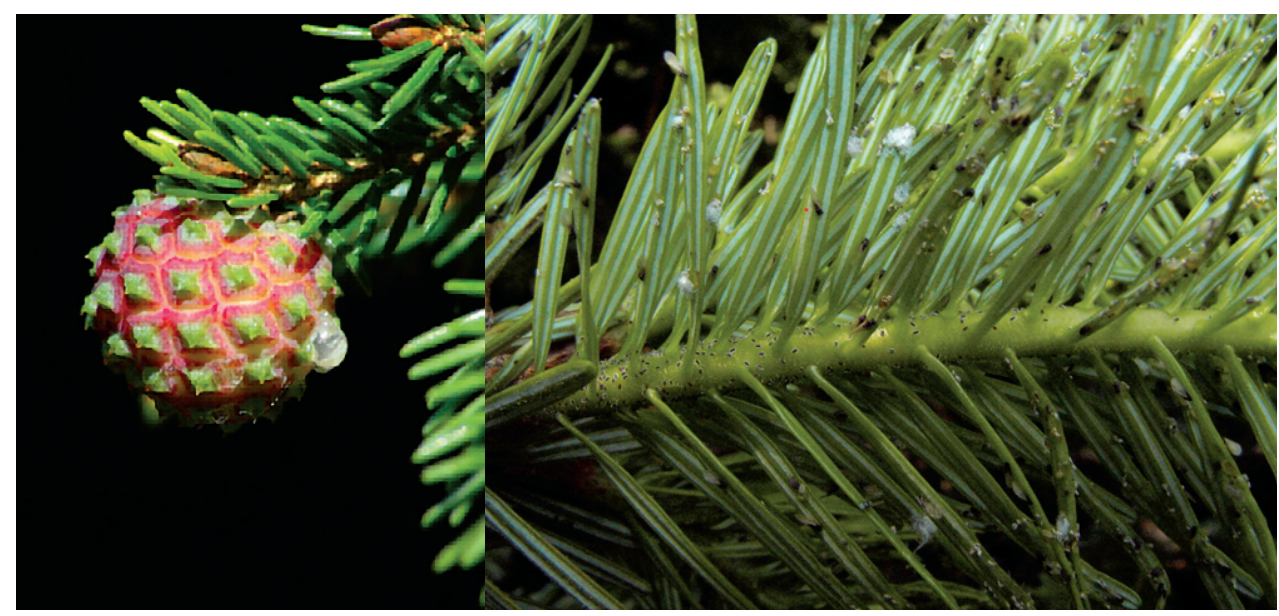

Credit: L. Goudzwaard 


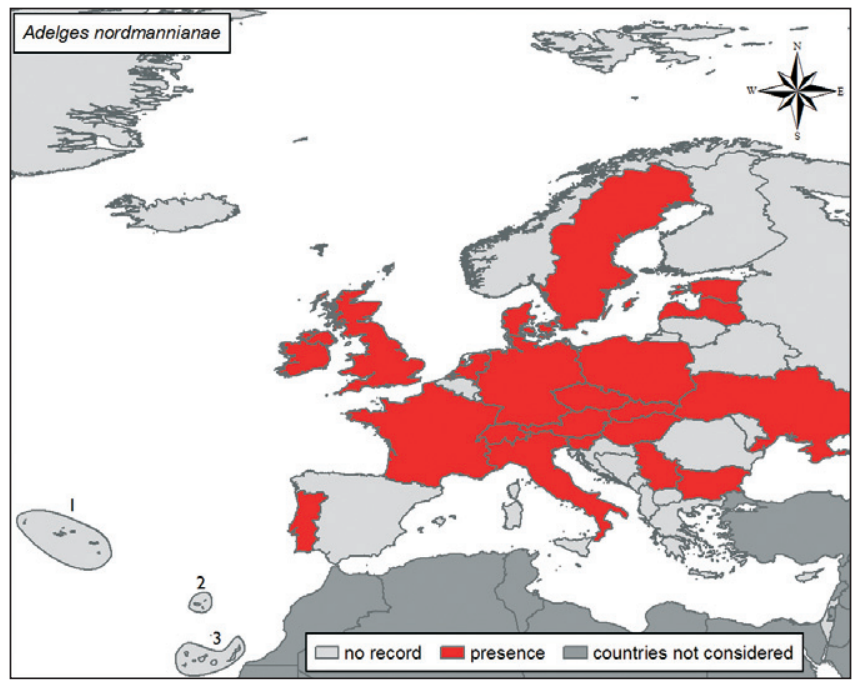

Native habitat (EUNIS code): G3 - Coniferous woodland.

Habitat occupied in invaded range (EUNIS code): G3 - Coniferous woodland; I2 Cultivated areas of gardens and parks; X24 - Domestic gardens of city and town centres; i.e. Christmas tree plantations (A. nordmannianae) in forests and on arable field land.

Native range: Mountain areas of Caucasus, Northeastern Turkey (Pontus) and Crimea.

Introduced range: First detected in 1840 in Germany, then spreading to stands of native Abies alba throughout the distribution range of this tree species in Europe (Map). However native Norway spruce, Picea abies, has not been accepted as a primary host. Therefore, the sexual life cycle rarely occurs in Europe.

Pathways: Forestry plantations of exotic conifers and trade of ornamental trees.

Impact and management: Aphid suction curls needles on new twigs. At severe attack levels, honeydew production may cause formation of sooty mould, loss of needles and even death of the leading shoot. Attacks are more abundant and severe in the region of introduction than in the region of origin. Silver fir woolly aphid has developed into the severest pest problem for Christmas tree production in Europe. Silver fir woolly aphid is responsible for the major part of insecticides used in Christmas trees.

\section{Selected references}

Eichhorn O (1991) On the generation cycle of Dreyfusia nordmannianae Eckst. (Hom., Adelgidae). Journal of Applied Entomology 112: 217-219.

Schneider-Orelli O, Schaeferrer C, Wiesmann R (1929) Untersuchungen über die Weisstannenlaus Dreyfusia nüsslini C.B. in der Schweiz. Mitteilungen der schweizerischen Cebtralanstalt für das forstliche Versuchswesen 15: 191-242.

Varty IW (1956) Adelges Insects of Silver Firs. Edinburgh: Her Majesty's Stationery Office. 75 pp. 


\title{
14.31 - Bemisia tabaci (Gennadius, 1889) - Cotton whitefly (Hemiptera, Aleyrodidae)
}

\author{
Alain Roques
}

Description and biological cycle: Small, about $1 \mathrm{~mm}$ long, sap-sucking whitefly with two pairs of white wings and a white to light yellow body, covered with waxy powdery material (Photo left). Larvae also sap-sucking, feeding on $>900$ plant species. This taxon corresponds to a species complex that comprises a large number of genetically variable populations, some of which are discernible owing to distinct phenotypes. Well-studied B.tabaci populations that have been differentiated are referred to as races or biotypes. The B biotype is a particularly aggressive variant. One female produces 80-300 eggs per lifetime. Unmated females produce parthenogenetically only male progeny. Development needs $15-70 \mathrm{~d}$ from egg to adult depending on temperature $\left(10-32{ }^{\circ} \mathrm{C}, 27^{\circ} \mathrm{C}\right.$ is optimal), while $11-15$ generations per year are possible (Photo right-empty exuviae).

Native habitat (EUNIS code): Unknown.

Habitat occupied in invaded range (EUNIS code): I- Regularly or recently cultivated agricultural, horticultural and domestic habitats; I1 - Arable land and market gardens; glasshouses.

Native range: Asia -Pacific region. Cotton whitefly appears to be a species complex. Recent genetic data indicate as many as ten morphologically indistinguishable species indigenous to the Asia-Pacific region.

Introduced range: Widely spread in the last 15 years. Reported at present from all continents; present in the field in most of Southern Europe but restricted to glasshouses in Western, Central and Northern Europe (Map). Apparently eradicated in Finland, Ireland and the United Kingdom.

Pathways : Intercontinental dispersal of eggs, nymphs and adults occurs with plant trade. Directional adult flight is limited but winds may carry flying adults over long distances due to their small size.

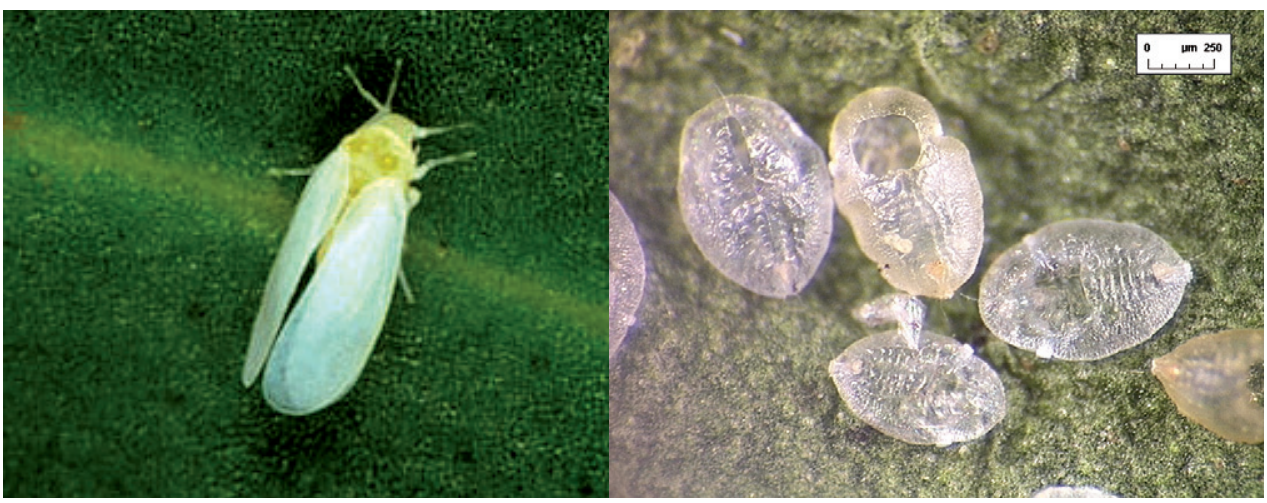

Credit:Jean-Yves Rasplus (left), Jean-Claude Streito (right) 


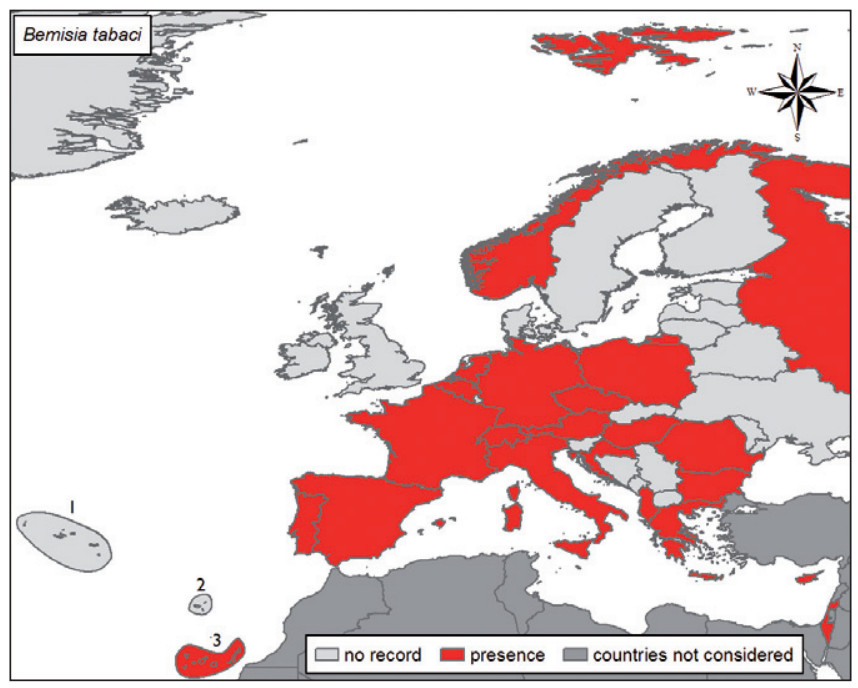

Impact and management: Heavy infestations cause important yield losses, ranging from $20-100 \%$ depending on the crop and season, to both field and glasshouse agricultural crops and ornamental plants. Three types of damage are observed. Direct feeding damage by adults and larvae may reduce host vigour and growth, cause chlorosis and uneven ripening, and induce physiological disorders. Indirect damage results from accumulation of honeydew produced by nymphs, which serves as a substrate for the growth of black sooty mould on leaves and fruit. The mould reduces photosynthesis and lessens market value of the plant or yields it unmarketable. Finally, it is the most important vector of plant viruses worldwide. As vector of over 100 plant viruses, a small population of whiteflies is sufficient to cause considerable damage. Avoid importations from infested areas. Sequential plantings, avoiding the establishment of affected crops near infested fields, can be used. Adult activity and abundance can be monitored using yellow sticky traps. Chemical control: a number of insecticides provided effective control in the past, but resistance has developed rapidly. Biological control: the use of natural enemies such as chalcids (e.g., Encarsia formosa, Eretmocerus spp.) and the entomopathogenic fungus Verticillium lecanii is moderately efficient, but cannot sufficiently decrease infestations to stop virus transmission.

\section{Selected references}

De Barro PJ (2005) Genetic structure of the whitefly Bemisia tabaci in the Asia-Pacific region revealed using microsatellite markers. Molecular Ecology 14: 3695-3718.

Martin JH, Rapisarda C, Mifsud D (2000) The whiteflies (Hemiptera: Aleyrodidae) of Europe and the Mediterranean Basin. Bulletin of Entomological Research 90: 407-448.

Moya A, Guirao P, Cifuentes D, Beitia F and Cenis JL (2001) Genetic diversity Genetic diversity of Iberian populations of Bemisia tabaci (Hemiptera: Aleyrodidae) based on random amplified polymorphic DNA-polymerase chain reaction. Molecular Ecology 10: 891-897. 


\title{
14.32 - Trialeurodes vaporariorum (Westwood, 1856) - Glasshouse whitefly (Hemiptera, Aleyrodidae)
}

\begin{abstract}
Alain Roques
Description and biological cycle: Adult small, white to pale yellow, about $1 \mathrm{~mm}$ long; the wings held relatively flat when at rest and coated with powdery wax (Photo-adult male). While single whitefly can be difficult to see, large numbers clustered on the underside of leaves are very obvious. They tend to fly rapidly when the plant is disturbed. The female may lay more than 500 eggs during its 3-6 weeks- long life. Eggs are laid in a circle on smooth leaves; on hairy leaves, they are more dispersed and less regularly situated. The eggs hatch about 9 days after egg-laying at $21^{\circ} \mathrm{C}$. Newly emerged nymphs are mobile for a short period before settling to feed, their stylets inserted in leaf tissue, passing through three instars. Then, they stop feeding, moult and remain in a pupa for about 18 days. Reproduction is essentially parthenogenetic. Overwintering occurs at all instars. In northern climates, this whitefly usually lives in glasshouses on wild plants, or in summer on adjacent plants outside. Further south, adults may also overwinter on wild plants growing outdoors if the climatic conditions are not too severe. Reproduction occurs throughout the year when conditions are favourable, with several generations overlapping. Under optimum conditions at $21-24^{\circ} \mathrm{C}$, the development from egg to adult takes about 3-4 weeks. Highly polyphagous, this species is capable of attacking 249 genera of plants. It attacks mainly vegetables, especially tomatoes, cucumbers and several other economic plants especially when they are grown in greenhouses. It can also be found on a wide selection of ornamentals, with a prediliction for Asteraceae, and of weeds, including sow thistles (Sonchus spp.), milkweed (Euphorbia peplus), and mallows (Malva spp.).
\end{abstract}

Native habitat (EUNIS code): Unknown.

Habitat occupied in invaded range (EUNIS code): J100- glasshouses; I- Regularly or recently cultivated agricultural, horticultural and domestic habitats; I1- Arable land and market gardens.

Native range: Central America, essentially tropical and subtropical.

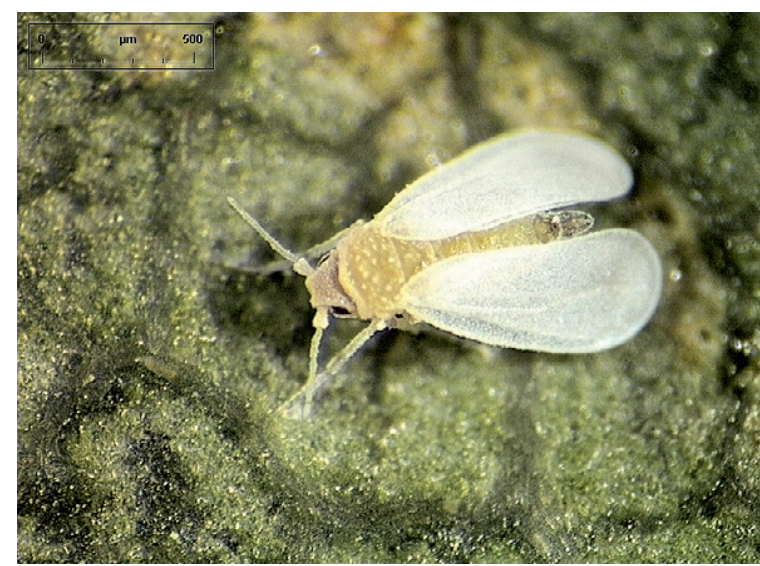




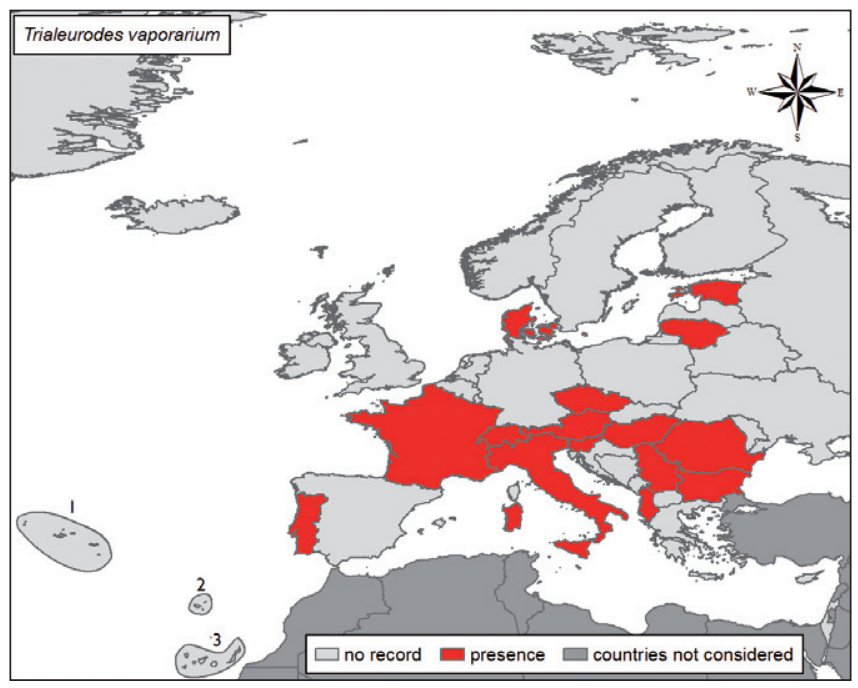

Introduced range: First recorded in Europe in Great Britain in 1856. Nowadays, present in the major part of Western, Central and Southern Europe (Map). In cold regions, this whitefly is found only in heated glasshouses whilst it may occur outdoors in southern Europe on both wild and cultivated plants.

Pathways: Intercontinental dispersal of eggs, nymphs and adults occurs with plant trade. Directional adult flight is limited but winds may carry flying adults over long distances due to their small size.

Impact and management: A major pest in glasshouses. The whitefly is responsible for very severe damage on vegetables through both sap sucking, and the production of honeydew and the consequent formation of sooty moulds. Up to 2,000 nymphs may be found on a single bean leaf, each being capable of producing 20 drops of honeydew in an hour. Affected tomatoes cannot be sold. The species may also transmit viruses.A certain resistence to synthetic insecticides has been observed, particularly amongst parthenogenetic strains. Populations are controlled by the action of entomophagous species such as fungi, ladybirds, Neuropterae, and hymenopteran chalcids. Biological control is widely used in commercial glasshouses, by introduction of a small endoparasitic wasp, Encarsia Formosa Gahan, which attacks and kills the whiteflies. Other biological control agents becoming available to gardeners include a small black ladybird, Delphastus sp., and a small predatory bug, Macrolophus sp.

\section{Selected references}

Kirk AA, Lacey LA, Roditakis, N Brown JK (1993) The status of Bemisia tabaci (Hom.: Aleyrodidae), Trialeurodes vaporariorum (Hom.: Aleyrodidae) and their natural enemies in Crete. Entomophaga 38: 405-410.

Martin JH, Rapisarda C, Mifsud D (2000) The whiteflies (Hemiptera: Aleyrodidae) of Europe and the Mediterranean Basin. Bulletin of Entomological Research 90: 407-448.

Van Dorst HJM, Huijberts N, Bos L (1983) Yellows of glasshouse vegetables, transmitted by Trialeurodes vaporariorum. European Journal of Plant Pathology 89: 171-184. 


\title{
14.33 - Aphis gossypii Glover, 1877 - Cotton aphid, melon aphid (Hemiptera, Aphididae)
}

\begin{abstract}
Alain Roques
Description and biological cycle: Small aphid, about $2 \mathrm{~mm}$ long, phloem-feeding with two virginiparous forms. Winged and wingless, highly variable in colour from yellowish green to partly black; immature stages pale yellow to pale green (Photo-wingless female and immatures). Highly polyphagous species, a major pest of cultivated plants in the families Cucurbitaceae, Rutaceae, Malvaceae and of Citrus trees. Flight range of winged adults is limited. Long-range dispersal of eggs, immature stages and adults is human-mediated with the transport of infested plant material. In Europe, it reproduces by apomictic parthenogenesis, and can produce nearly sixty generations a year. The optimal temperature is $21-27^{\circ} \mathrm{C}$. Viviparous females produce 70-80 offspring at a rate of 4.3 per day. Developmental periods of immature stages vary from $21 \mathrm{~d}$ at $10^{\circ} \mathrm{C}$ to $4 \mathrm{~d}$ at $30^{\circ} \mathrm{C}$. Good resistance to summer heat. Dry weather conditions are favourable and heavy rainfall decreases population sizes.
\end{abstract}

Native habitat (EUNIS code): Unknown.

Habitat occupied in invaded range (EUNIS code): I1 - Arable land and market gardens; I2- Cultivated areas of gardens and parks; J100- glasshouses.

Native range: Unknown.

Introduced range: Found in tropical and temperate regions throughout the world except northern areas. Common in Africa, Australia, Brazil, East Indies, Mexico and Hawaii, Present in most of Europe (Map) but it can develop outdoors only in Southern Europe, surviving in glasshouses in Northern Europe.

Pathways: Passive transport with plant trade including vegetables, fruits, cut flowers, ornamental plants, bonsai, and nursery stock.

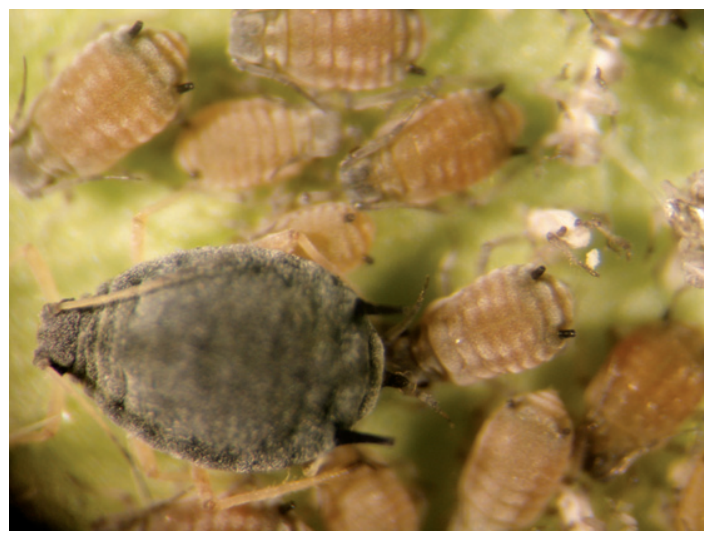

Credit:Jérôme Carletto 


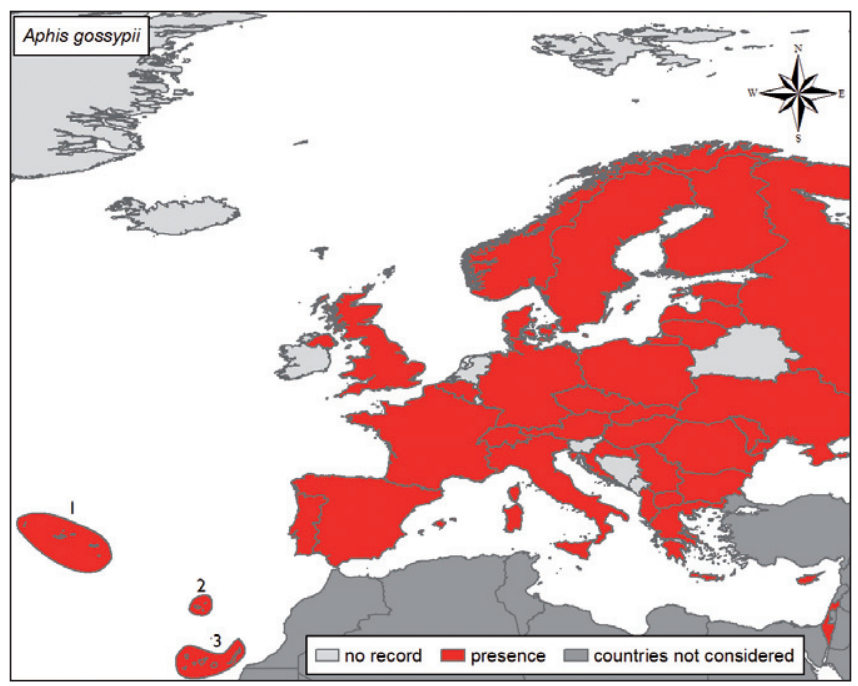

Impact and management: Economically important because nymphs and adults feed on the underside of leaves, or on growing tip of vines, sucking nutrients from the plant. The foliage may become chlorotic and die prematurely. Feeding also causes distortion and leaf curling, hindering photosynthetic capacity of the plant. In addition, honeydew production fosters growth of sooty moulds, resulting in a decrease of fruit/vegetable quantity and quality. Vector of crinkle, mosaic, rosette, Tristeza citrus fruit (CTV) and other virus diseases. Impact is especially high on courgette, melon, cucumber, aubergine, strawberry, cotton, mallow and citrus. Resistance has arisen to many pesticides. Insecticides should be used sparingly and in conjunction with other non-chemical control methods. Parasitoid aphidiid wasps (e.g., Aphidius colemanior, Lysiphlebus testaceipes), aphelinid wasps (e.g., Aphelinus gossypii), predatory midges (e.g., Aphidoletes aphidimyza), predatory anthocorid bugs (e.g., Anthocoris spp.), predatory coccinelids, and entomopathogenic fungi (e.g., Neozygites fresenii) are efficient and available for biocontrol in glasshouse crops.

\section{Selected references}

Fuller SJ, Chavigny P, Lapchin L, Vanlerberghe-Masutti F (1999) Variation in clonal diversity in glasshouse infestations of the aphid, Aphis gossypii Glover in southern France. Molecular Ecology 8: 1867-77.

Margaritopoulos JT, Tzortzi M, Zarpas KD, Tsitsipis JA, Blackman RL (2006) Morphological discrimination of Aphis gossypii (Hemiptera: Aphididae) populations feeding on Compositae. Bulletin of Entomological Research 96: 153-165.

Martin B, Rahbé Y, Fereres A (2003) Blockage of stylet tips as the mechanism of resistance to virus transmission by Aphis gossypii in melon lines bearing the Vat gene. Annals of Applied Biology 142: 245-250. 


\subsection{4 - Cinara curvipes (Patch, 1912) - Bow-legged fir aphid (Hemiptera, Aphididae)}

\section{Olivera Petrović-Obradović}

Description and biological cycle: Wingless viviparous females are pearlike, 4-6 mm long. Body is dark brown, almost black, glossy, with two long white wax lines, extending dorsally from head to end of abdomen (Photo). Cornicles are short, on an oval sclerotised plate. Cauda are short and rounded. Rostrum is very long and may exceed the length of the body. Winged viviparous females are somewhat finer, with well developed wings. Monoecious species (host alternation does not occur) on Abies spp., Cedrus athlantica and Cedrus deodora. In America, develops a sexual generation in autumn, but in Europe, males have not been observed and it seems that it has anholocyclic* development.

Native habitat (EUNIS code): G- Woodland and forest habitats and other wooded land.

Habitat occupied in invaded range (EUNIS code): G3- Coniferous woodland; G3F- Highly artificial coniferous woodland; G5- Lines of trees, small anthropogenic woodlands, recently felled woodland, early-stage woodland; I2- Cultivated areas of gardens and parks; X24- Domestic gardens of city and town centres; X25-Domestic gardens of villages and urban peripheries.

Native range: North America and Mexico

Introduced range: First recorded in Germany in 2000, later found in Serbia (2001), Switzerland (2007), Slovakia (2007) and Czech Republic (2008).

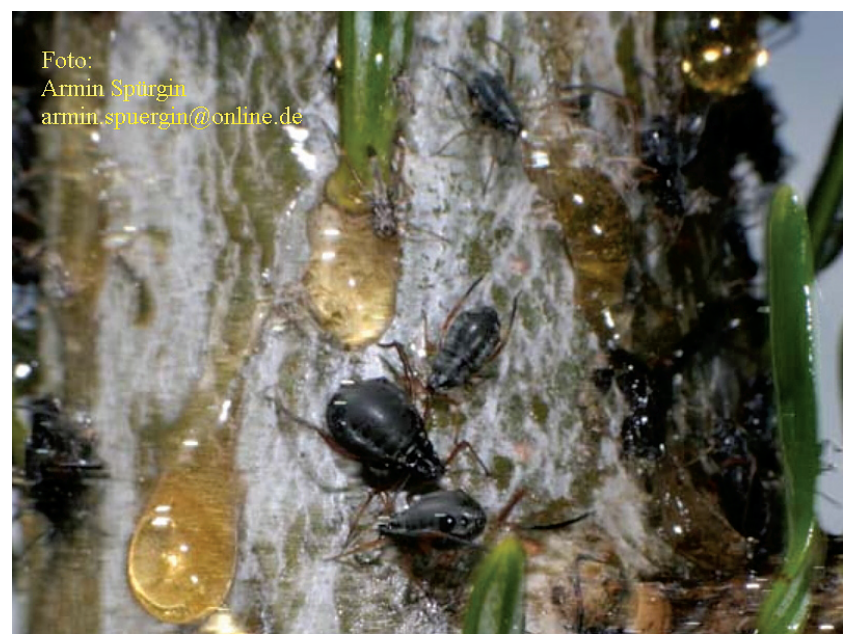

Credit:Armin Spürgin 


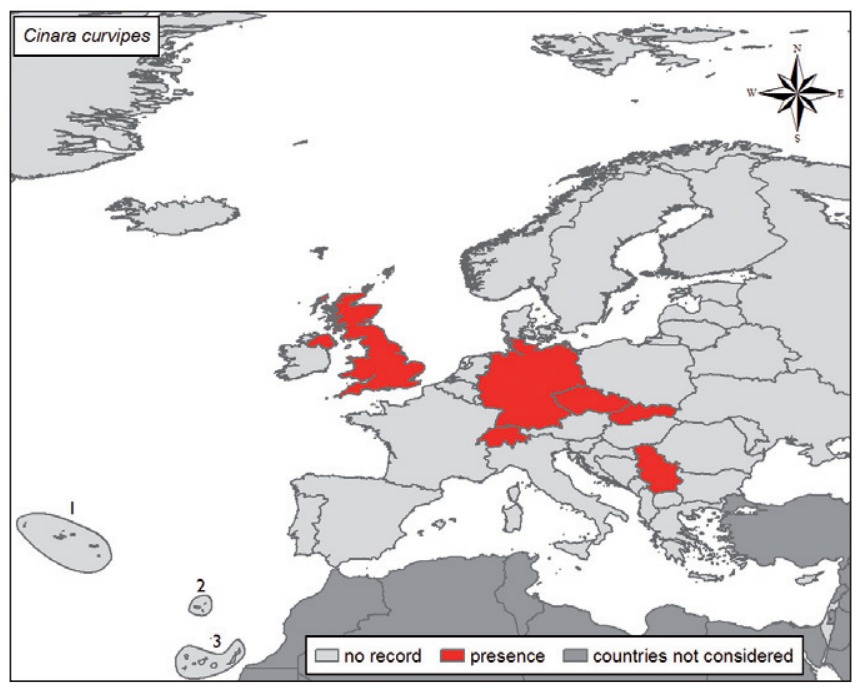

Pathways: Introduced with infested coniferous host plants. Spread in Europe continues by transport of the host plants and by active and passive flight of winged viviparous females.

Impact and management: Economically one of the most important aphids as it is a pest of many crops (peach, potato, tobacco, sugar beet, vegetables, ornamental plants). Also, among aphids, it is the most efficient vector of plant viruses, transmitting more than 100 nonpersistent and many important persistent viruses, including Potato leaf roll (PLRV), Bean leaf roll (BLRV), Pea enation mosaic (PEMV) and Beet yellow net (BYNV). For monitoring flight activity, yellow water traps and suction traps are used. For chemical control, since resistance to insecticide is easily developed, only a few new insecticides are sufficiently effective. Many predators act as biological controls in colonies of the pest, especialy Coccinelidae, Syrphidae, Chrysopidae, Miridae and Cecidomyiidae (Aphidoletes aphidomyza Rond.). A very rich parasitoid complex includes 18 species of Aphidiidae wasp. Two of them are used in control in glasshouses: Aphididus colemani Vier. and Aphidius ervi Hal.

\section{Selected references}

Balachowsky A, Mesnil L (1935) Les insectes nuisibles aux plantes cultivées. Paris, France: Mery L. 1921 pp.

Blackman RL, Eastop VF (2000) Aphids on the World's Crops - an Identification and Information Guide. $2^{\text {nd }}$ edn. Chichester UK: John Wiley \& Sons. 476 pp.

Theobald FV (1926)The plant lice or Aphididae of Great Britain, Vol I., London, UK: Headley Brothers. 372pp. 


\subsection{5 - Macrosiphum euphorbiae (Thomas, 1878) - Potato aphid (Hemiptera, Aphididae)}

\section{Olivera Petrović-Obradović}

Description and biological cycle: Medium-sized to large aphid (1.7-3.5 mm), spindle-shaped, green (Photo) or pink. Adults are rather shiny and larvae have a light dusting of greyish-white wax. Mainly anholocyclic*, usually with only winged and wingless forms present in colonies. Sexual morphs are produced on primary host (Rosa spp.) in North America and only rarely in other parts of the world. Highly polyphagous on secondary hosts, feeding on plant species in more than 20 different plant families. In Europe, develops usually without sexual generation. During winter, regularly found in glasshouses.

Native habitat (EUNIS code): Unknown.

Habitat occupied in invaded range (EUNIS code): : I1 - Arable land and market gardens; I2- Cultivated areas of gardens and parks; glasshouses; X7 - Intensively-farmed crops interspersed with strips of spontaneous vegetation. X24 - Domestic gardens of city and town centres; X25: Domestic gardens of villages and urban peripheries.

Native range: North America.

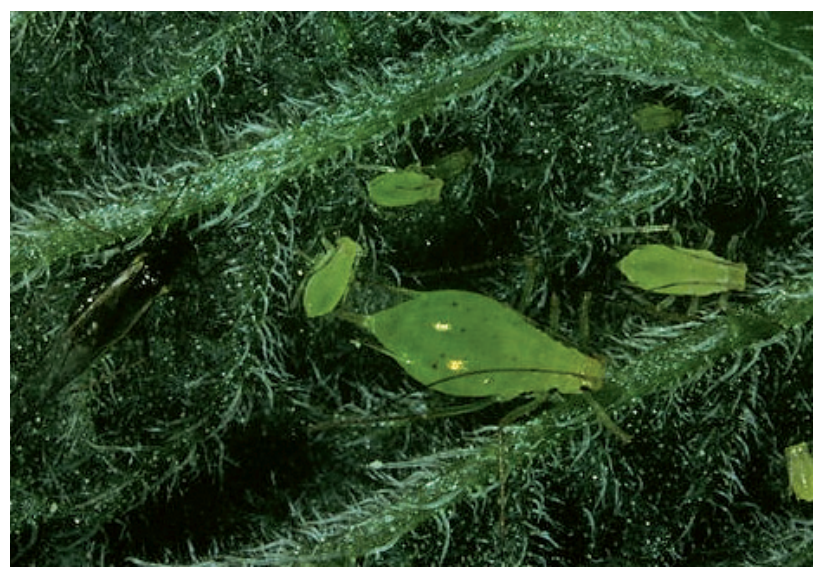

Credit: Rémi Coutin/ OPIE 


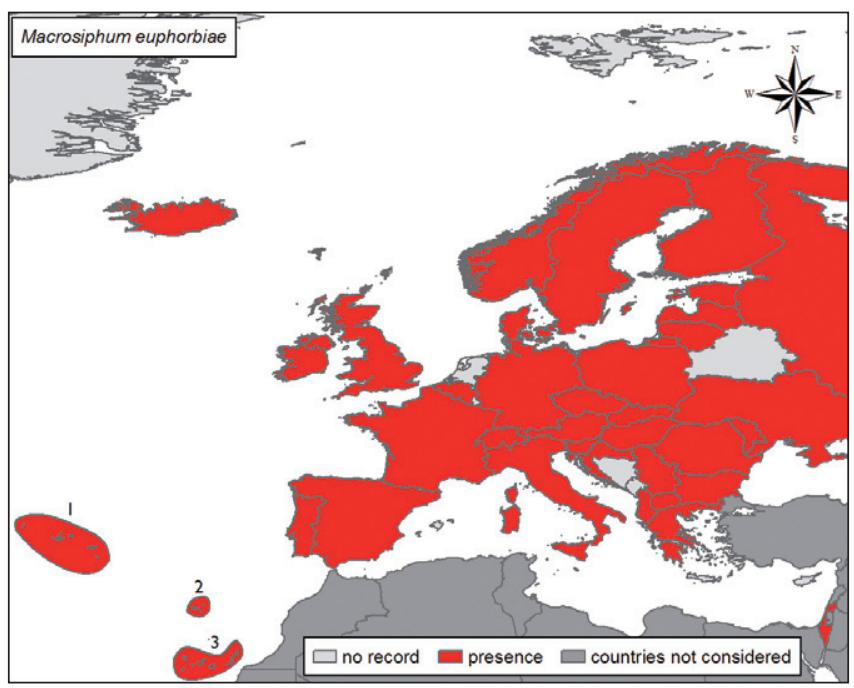

Introduced range: Cosmopolitan species. In Europe, first found in 1917 in Great Britain. Then, the potato aphid colonized most of Europe (Map).

Pathways: Trade of ornamentals.

Impact and management: Serious pest of many crops (potato, vegetable, flowers), causing direct damage by sucking nutrients and indirect damage as a vector of viruses. This aphid can transmit more than 40 non-persistent viruses and five persistent viruses (potato leaf roll, beet yellow net, bean leaf roll, zucchini yellow mosaic and sweet potato leaf-speckling virus). Monitoring can be effected using yellow water traps and suction traps. Chemical control involves use of selective insecticide and is often both necessary and effective. Many specific predators and parasitoids can be used for biological control, epecially in glasshouses.

\section{Selected references}

Blackman RL, Eastop VF (2000) Aphids on the World's Crops - an Identification and Information Guide. $2^{\text {nd }}$ edn. Chichester UK: John Wiley \& Sons. 476 pp.

Eastop VF (1958) The history of Macrosiphum euphorbiae (Thomas) in Europe. The Entomologist 91: 198-201. 


\title{
14.36 - Myzocallis walshii (Monell, 1879) (Hemiptera, Aphididae)
}

\author{
Ejup Çota
}

Description and biological cycle: Small $(1.5-2.0 \mathrm{~mm})$, delicate, usually yellowish aphid with a knobbed cauda and bilobed anal plate. Nymphs usually have capitate dorsal hairs. Adult viviparous females (viviparae) are all alate. The life cycle is monoecious and holocyclic. Not antattended. Alate viviparae of $M$. (Agriomyzus) castanicola have a distinct dark medial stripe on head and thorax, black spots on abdomen, dark siphunculi* and dark $2^{\text {nd }}$ antennal segment. The dark pigmentation is less distinct in spring forms. Sides of pronotum and mesonotum of both species bear a black band extending from the eye to the base of hind wings. The late-summer form of $M$. (Lineomyzocallis) walshii has a broad foreground band of black pigment from the costal vein in the forewing, extending well past the stigma to the wing apex (Photo left-alate viviparous female of summer form; right-ovipara in aautumn). Mainly associated with Quercus rubra, the American red oak, but attacks other oaks of North American origin (Q. coccinea, $Q$. palustris) and one native species (Q. robur). Over-winters in the egg stage. Eggs hatch in the spring and give rise to the first of several asexual generations in which winged (alate) parthenogenic females give rise to wingless (apterous) nymphs that develop into alate parthenogenic females. In late fall, the sexual generation begins with production of apterous females (oviparae) and alate males. When mature and mated, the oviparae lay from 4-6 eggs/female in cracks and crevices among the bark, shortly before the leaves begin to fall.

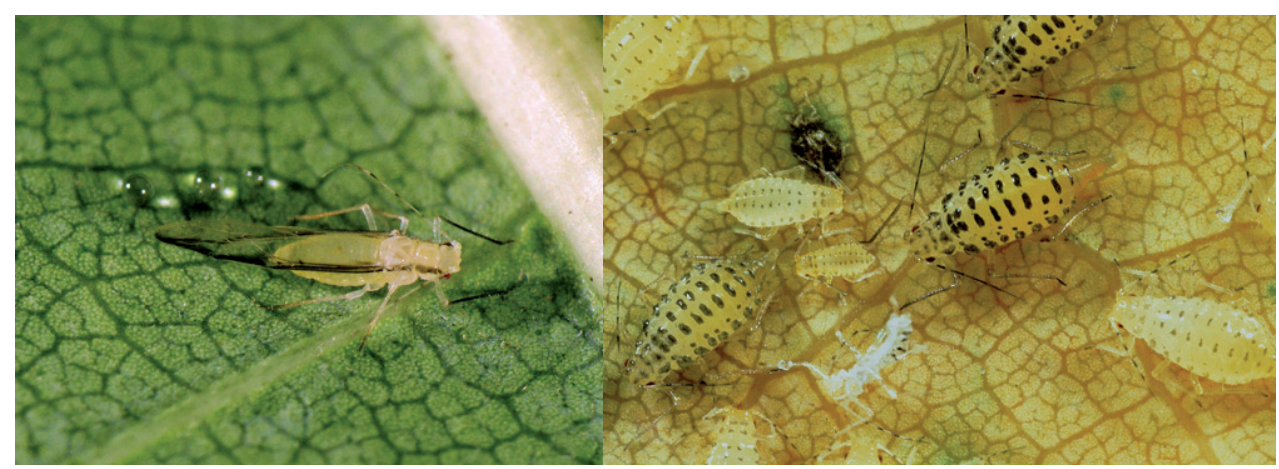

Credit:Jan Havelka 


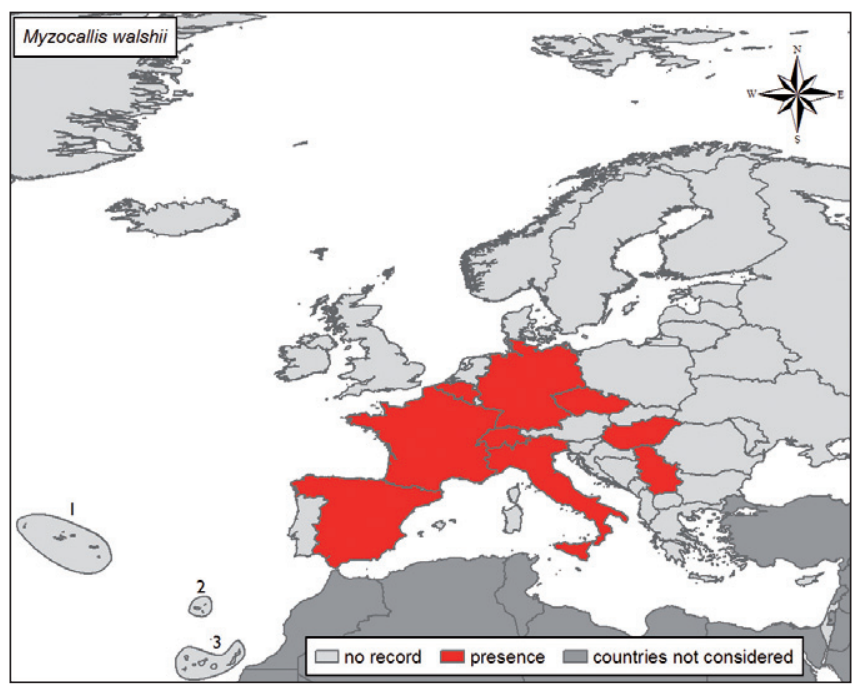

Native habitat (EUNIS code): G- Woodland and forest habitats and other wooded land.

Habitat occupied in invaded range (EUNIS code): I1- Arable land and market gardens; I2 - Cultivated areas of gardens and parks.

Native range: North America

Introduced range: Myzocallis walshii was detected for the first time in Europe in 1988 (France), and subsequently in several other European countries (Switzerland, Spain, Andorra, Italy, Belgium and Germany-Map).

Pathways: Accidental introduction with trade of ornamental plants.

Impact and management: Monitoring can be carried out using yellow sticky traps. As a mechanical means these exert limited control on populations. A number of aphicides can be used for chemical control as well as biological control agents, such as Aphidoletes spp, and Aphidius spp.

\section{Selected references}

Hullé M, Renoust M, Turpeau E (1998) New aphid species detected by permanent aerial sampling programmes in France. In: Nieto Nafria JM, Dixon AFG (Eds) Aphids in Natural and Managed Ecosystems. León, Spain: Universidad de León, Secretariado de Publicaciones. 365-369.

Remaudière G (1989) Découverte en France de l'espèce américaine Myzocallis (Lineomyzocallis) walshii (Monell) (Hom.Aphididae). Revue Francaise d'Entomologie: 14: 172. 


\subsection{7 - Myzus persicae (Sulzer, 1776) - Peach potato aphid (Hemiptera, Aphididae)}

\section{Olivera Petrović-Obradović}

Description and biological cycle: Small to medium-sized aphid (1.2-2.1 mm), yellow-green, grey-green, pink or red, not shiny. The aphid on tobacco is usually red, as well as specimens kept in cold conditions. Winged forms have a black central dorsal patch on the abdomen. Both winged and wingless forms are present in colonies (Photo left-Colony on tomato). Situated on the underside of leaves, aphids excrete honeydew. They curl leaves of peach in spring (Photo right) and migrate on to many secondary hosts in summer. Many generations can be produced a year with very rapid development under favorable conditions. Highly polyphagous species. The sexual phase occurs on the primary host, Prunus persica. In glasshouses and where outdoor conditions are good, parthenogenetic development occurs all year round on secondary hosts. Secondary hosts are very numerous, feeding on plants in over 40 different families. Populations colonizing tobacco are recognized as subspecies Myzus persicae nicotianae (Blackman, 1987).

Native habitat (EUNIS code): Unknown.

Habitat occupied in invaded range (EUNIS code): I1 - Arable land and market gardens; I2- Cultivated areas of gardens and parks; glasshouses; X7- Intensively-farmed crops interspersed with strips of spontaneous vegetation. X24- Domestic gardens of city and town centres; X25- Domestic gardens of villages and urban peripheries.

Native range: Unknown, possibly Asia.

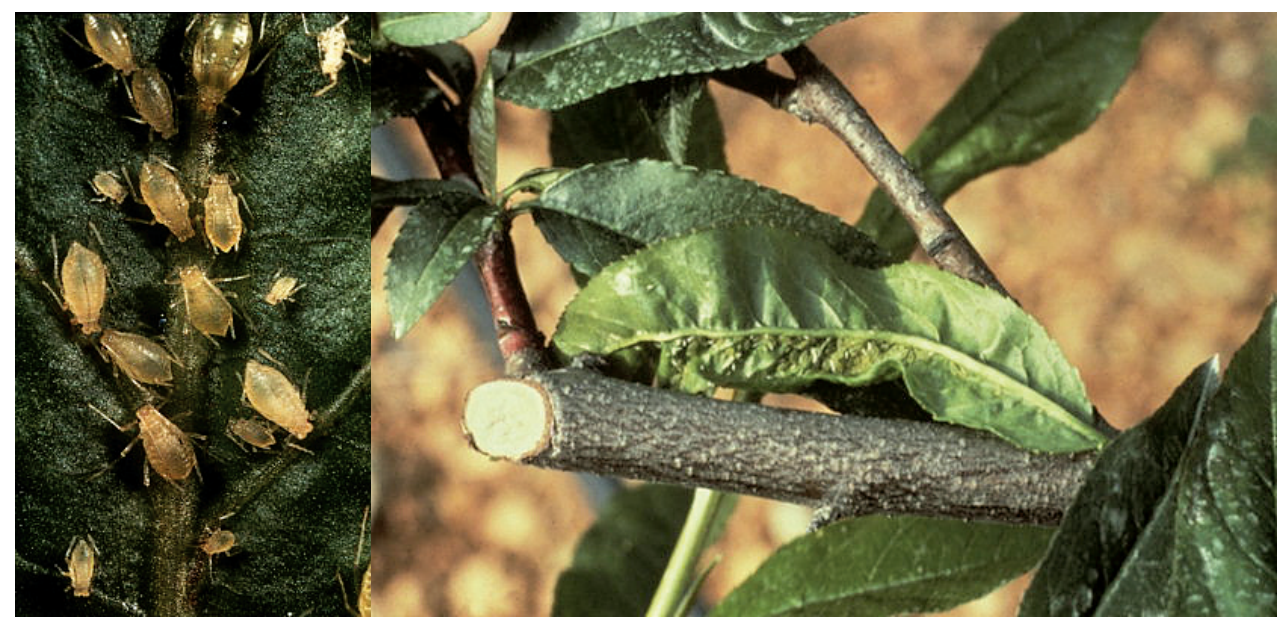

Credit: Rémi Coutin/ OPIE 


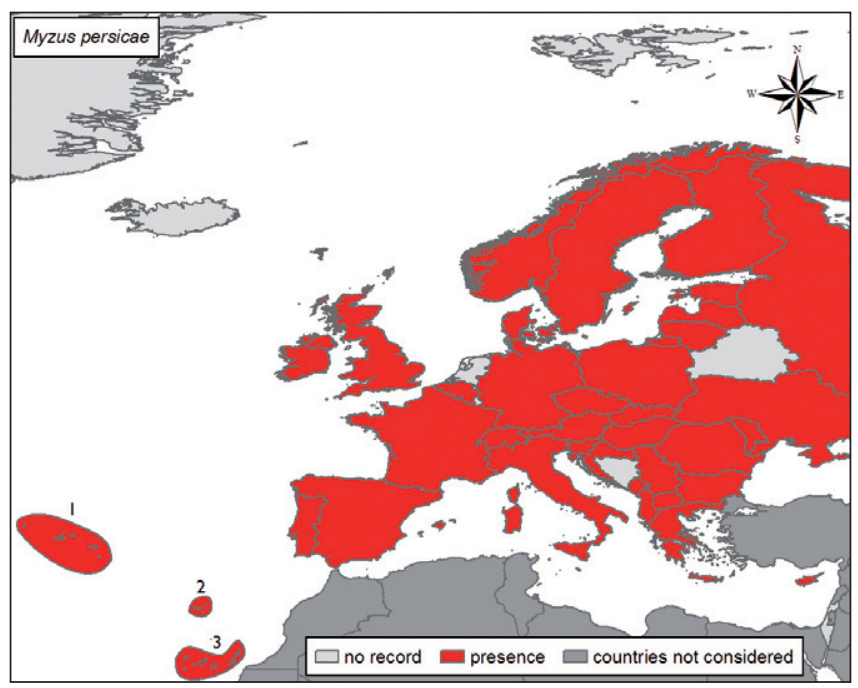

Introduced range: Cosmopolitan. Present since a very long time (since <1758) in Europe. Probably introduced repeatedly with infested plants.

Pathways: Plant trade.

Impact and management: Economically one of the most important aphids as it is a pest of many crops (peach, potato, tobacco, sugar beet, vegetables, ornamental plants). Also, among aphids, it is the most efficient vector of plant viruses, transmitting more than 100 nonpersistent and many important persistent viruses, including Potato leaf roll (PLRV), Bean leaf roll (BLRV), Pea enation mosaic (PEMV) and Beet yellow net (BYNV). For monitoring flight activity, yellow water traps and suction traps are used. For chemical control, since resistance to insecticide is easily developed, only a few new insecticides are sufficiently effective. Many predators act as biological controls in colonies of the pest, especialy Coccinelidae, Syrphidae, Chrysopidae, Miridae and Cecidomyiidae (Aphidoletes aphidomyza Rond.). A very rich parasitoid complex includes 18 species of Aphidiidae wasp. Two of them are used in control in glasshouses: Aphididus colemani Vier. and Aphidius ervi Hal.

\section{Selected references}

Balachowsky A, Mesnil L (1935) Les insectes nuisibles aux plantes cultivées. Paris, France: Mery L. 1921 pp.

Blackman RL, Eastop VF (2000) Aphids on the World's Crops - an Identification and Information Guide. $2^{\text {nd }}$ edn. Chichester UK: John Wiley \& Sons. 476 pp.

Theobald FV (1926)The plant lice or Aphididae of Great Britain, Vol I., London, UK: Headley Brothers. 372pp. 


\subsection{8 - Prociphilus fraxinifolii Riley ex Riley \& Monell, 1879 - Woolly Ash Aphid (Hemiptera, Aphididae)}

\section{Olivera Petrović-Obradović}

Description and biological cycle: Aphids 2.0-2.5 mm long, soft bodied, with well-developed wax glands, producing enormous quantities of wax rendering a snow-white appearance. Siphuncular* pores are absent. Both winged (Photo right) and wingless forms have yellow-green to pale green bodies. Compact colonies inhabit curled leaves at twig tips throughout the vegetative period (Photo left). Host plant is red ash (Fraxinus pennsylvanica) and some other American species of Fraxinus. In North America, P. fraxinifolii is holocyclic* but overwinters as parthenogenetic females in Europe. Host alternation does not occur.

Native habitat (EUNIS code): G- Woodland and forest habitats and other wooded land.

Habitat occupied in invaded range (EUNIS code): G1- Broadleaved decidous woodland; G5- Lines of trees, small anthropogenic woodlands, recently felled woodland, early-stage woodland; I2- Cultivated areas of gardens and parks; X24- Domestic gardens of city and town centres; X25- Domestic gardens of villages and urban peripheries.

Native range: North America and Mexico.

Introduced range: First recorded in Europe in 2003 in Hungary, then in Serbia and Bulgaria (Map). Arrived three hundred years after introduction of its host plants, the American species of Fraxinus. Also introduced into Chile and South Africa.

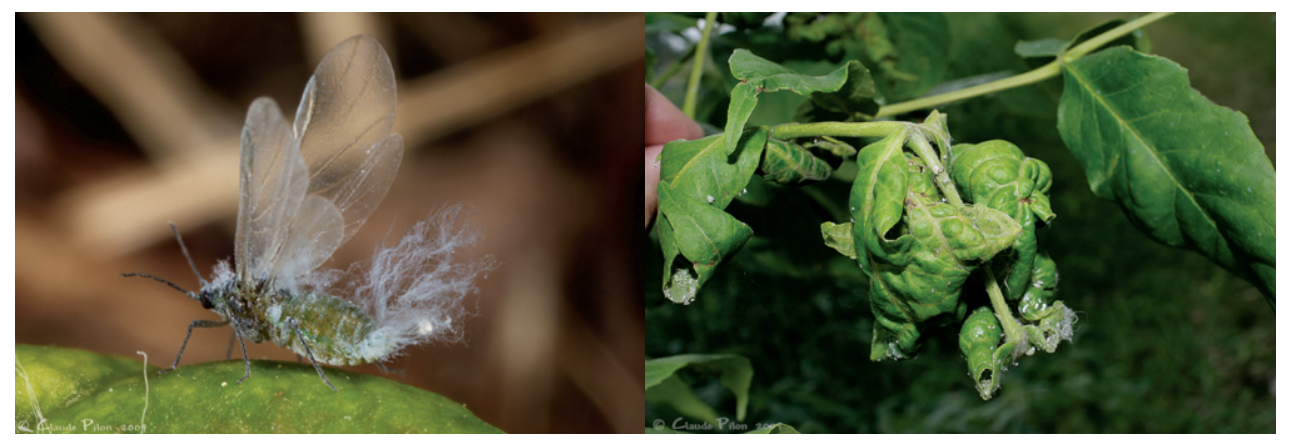

Credit: Claude Pilon 


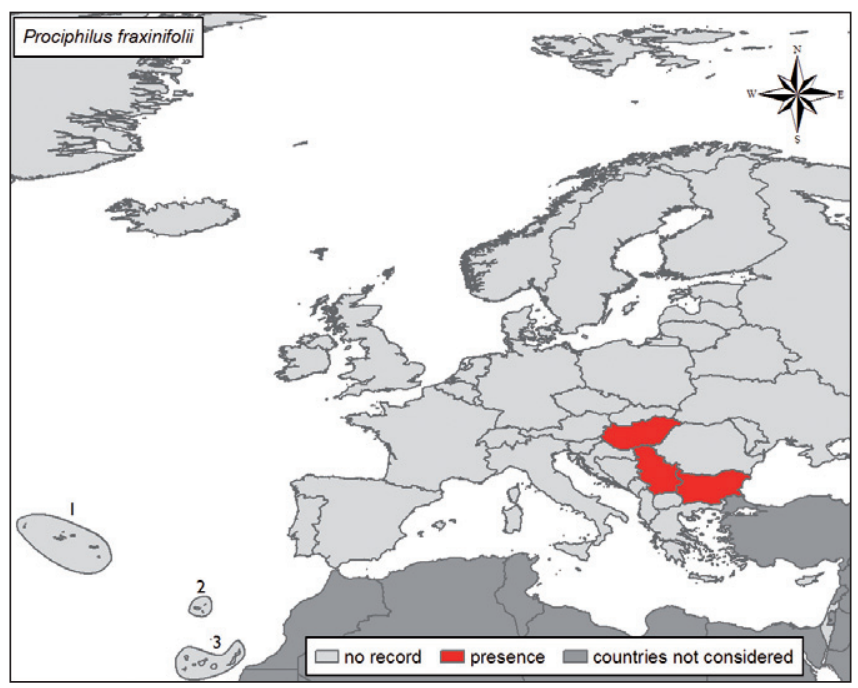

Pathways: Trade of ornamental plants.

Impact and management: Very destructive aphid because deformation of curled leaves and twigs make trees much less attractive. Colonies also occur on ash roots, where overwintering occurs in Europe. Key pest in nursery production of Fraxinus. For monitoring, it is important to make inspections of ash in early spring and to use systemic insecticides as soon as colonies appear. Biological control involves Aphelinus prociphili, the parasitoid in North America; no parasitoids are found in Europe. The natural enemy complex fails to keep plant damage below an acceptable level.

\section{Selected references}

Petrović-Obradović O, Tomanović Ž, Poljaković-Pajnik L, Vučetić A (2007) An invasive species of aphid, Prociphilus fraxinifolii (Hemiptera, Aphididae, Eriosomatinae), found in Serbia. Archives of Biological Sciences, Belgrade 59: 9-10.

Remaudière G, Ripka G (2003) Arrival in Europe (Budapest, Hungary) of American ash aphid, Prociphilus (Meliarhizophagus) fraxinifolii (Hemiptera, Aphididae, Eriosomatinae, Pemphigini). Revue Francaise d'Entomologie 25: 152. 


\subsection{9 - Toxoptera citricida (Kirkaldy, 1906) - Tropical citrus aphid, oriental black citrus aphid, brown citrus aphid \\ (Hemiptera, Aphididae)}

\section{Ejup Çota}

Description and biological cycle: Aphid with medium-sized body, 1.5-2.4 mm long, shiny, reddish-brown to black. Alates (Photo left) can be identified, using a pocket lens, by the wholly black third antennal segment which is succeeded by a pale fourth segment. Median nervure of forewings normally forked twice. Siphunculi* of alates about 1/6 body length and strongly sculptured, while cauda rather bulbously rounded at apex. Apterous forms should be examined microscopically to observe the very long, fine and erect hairs on the legs and body margins. Siphunculi* as in alates but relatively shorter (Photo-right). Cauda thick and bluntly rounded at the apex. Immature stages brown A useful character to distinguish T. citricidus from T. aurantii is that a distinct scraping sound produced by disturbed colonies of the latter, audible up to 45 $\mathrm{cm}$ away from the leaf, while $T$. citricidus are silent. Females are parthenogenetic and a single generation develops in 6-8 days. Tropical citrus aphids attack solely Citrus spp. Reproductive potential depends on the abundance of plant sap. About 30 generations are produced annually, depending on temperature. Winged females give rise to new infestations. Dark-brown to black colonies develop on young growths and are usually visited by ants.

Native habitat (EUNIS code): I - Regularly or recently cultivated agricultural, horticultural and domestic habitats.

Habitat occupied in invaded range (EUNIS code): I1 - Arable land and market gardens; I2 - Cultivated areas of gardens and parks; glasshouses.

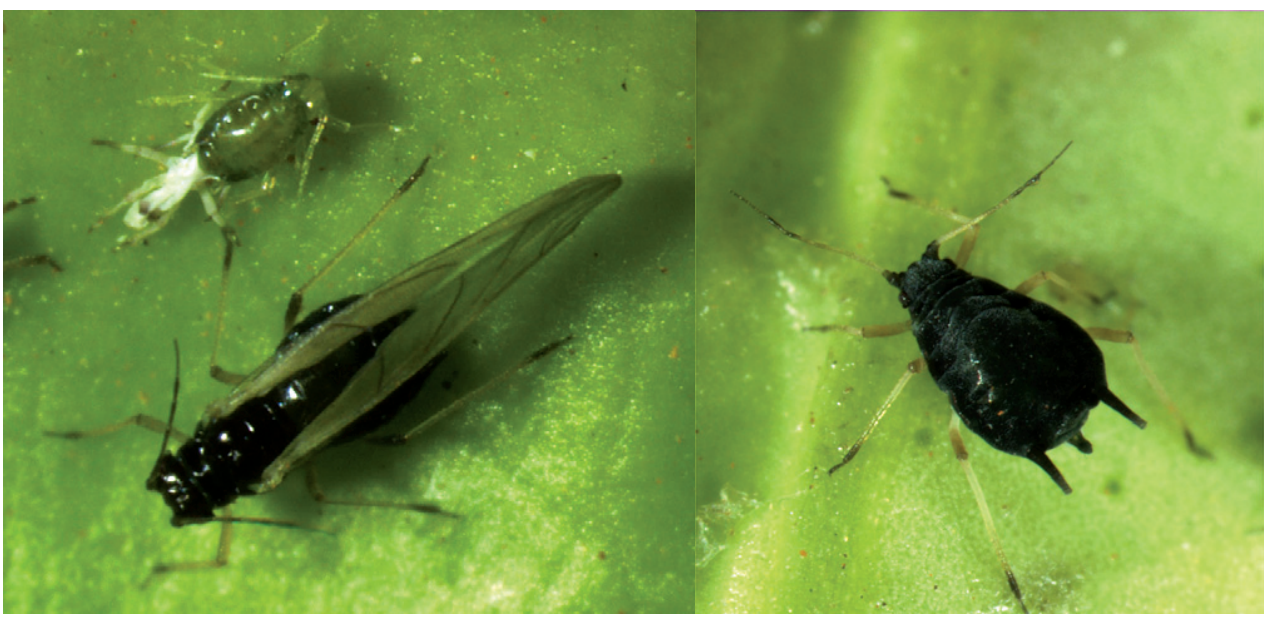




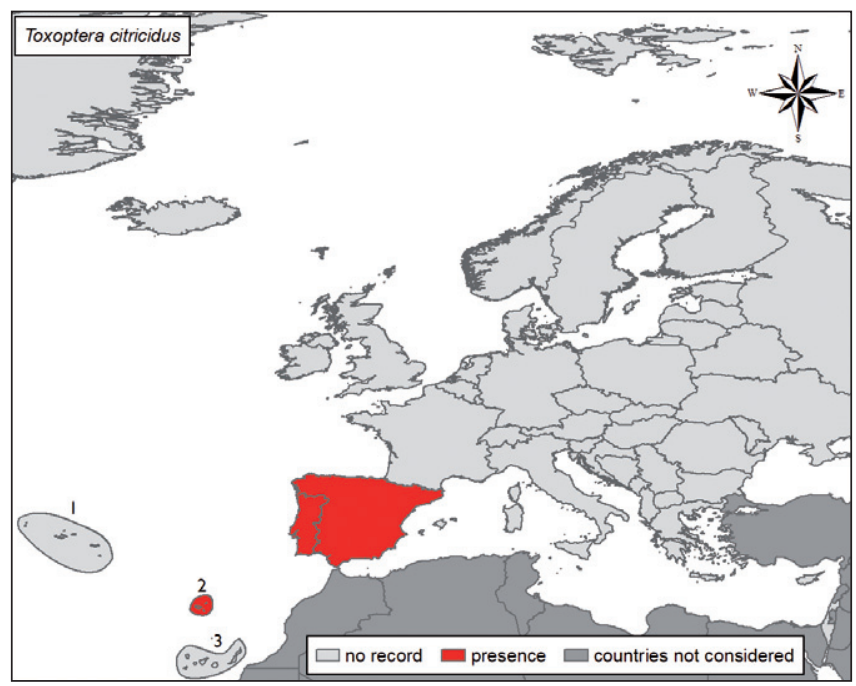

Native range: Occurs predominantly in humid tropical regions and presumably originated in south-east Asia.

Introduced range: First detected in Madeira in 1994, later observed in continental Portugal and Spain (Map).

Pathways: $T$. citricidus can spread locally by flight, but is very unlikely to be introduced into the region by natural means. Introduction occurs on potted plants and associated transportation materials.

Impact and management: Growth of shoots is greatly impaired and they become distorted; leaves become brittle and wrinkled and curl downwards. Attacked flowers fail to open or do so abortively since the ovaries are deformed. T. citricidus is an efficient vector of important virus diseases of citrus: citrus tristeza closterovirus, stem-pitting and seedling yellows strains. Control measures are intended to prevent damage to young shoots and fruits, and especially to suppress the formation of alates. Young trees are treated preventively with systemic insecticides. Many natural enemies are known (e.g. predators and entomopathogenic fungi). Some are being considered for use in integrated control programmes.

\section{Selected references}

Aguiar AMF, Fernandez A, Ilharco FA (1994) On the sudden appearance and spread of the

black citrus aphid Toxoptera citricidus (Kirkaldy) (Homoptera Aphidoidea) on the island of Madeira. Bocagiana 168: 1-7.

Doncaster JP, Eastop JF (1956) The tropical citrus aphid. FAO Plant Protection Bulletin 4: 109-110.

Ilharco FA, Sousa-Silva CR, Alvarez Alvarez A (2005) First report on Toxoptera citricidus (Kirkaldy) in Spain and continental Portugal (Homoptera, Aphidoidea). Agronomia Lusitana 51: 19-21. 


\title{
14.40 - Scaphoideus titanus Ball, 1932 - Vine leafhopper (Hemiptera: Cicadellidae)
}

\author{
Wolfgang Rabitsch
}

Description and biological cycle: Small leafhopper, average adult body size $5 \mathrm{~mm}$, ochrebrown to mottled dark brown (Photo), nymphs yellowish-white with two dark brown spots on abdomen. Females lay clusters of 10-12 eggs in late summer in crevices in the bark of one- or two-year-old grapevine wood. Eggs overwinter, and development from first instar to adult takes 35-40 days. Adults of the new generation appear in late spring with one generation per year. Larvae and adults live ampelophagously ${ }^{*}$, ie. monophagous on grapevine (Vitis vinifera).

Native habitat (EUNIS code): I1 - Arable land and market gardens.

Habitat occupied in invaded range (EUNIS code): I1 - Arable land and market gardens.

Native range: Nearctic species, originally present in the northeastern parts of USA and South Canada.

Introduced range: Unintentionally introduced to south-western France, presumably in the 1950s (first record in 1958), from where it subsequently spread to neighbouring countries: Italy (1963), western and southern Switzerland (1968), Slovenia (1983), Croatia (1987), northern Spain (1995) and northern Portugal (1999). Later, the species extended its range

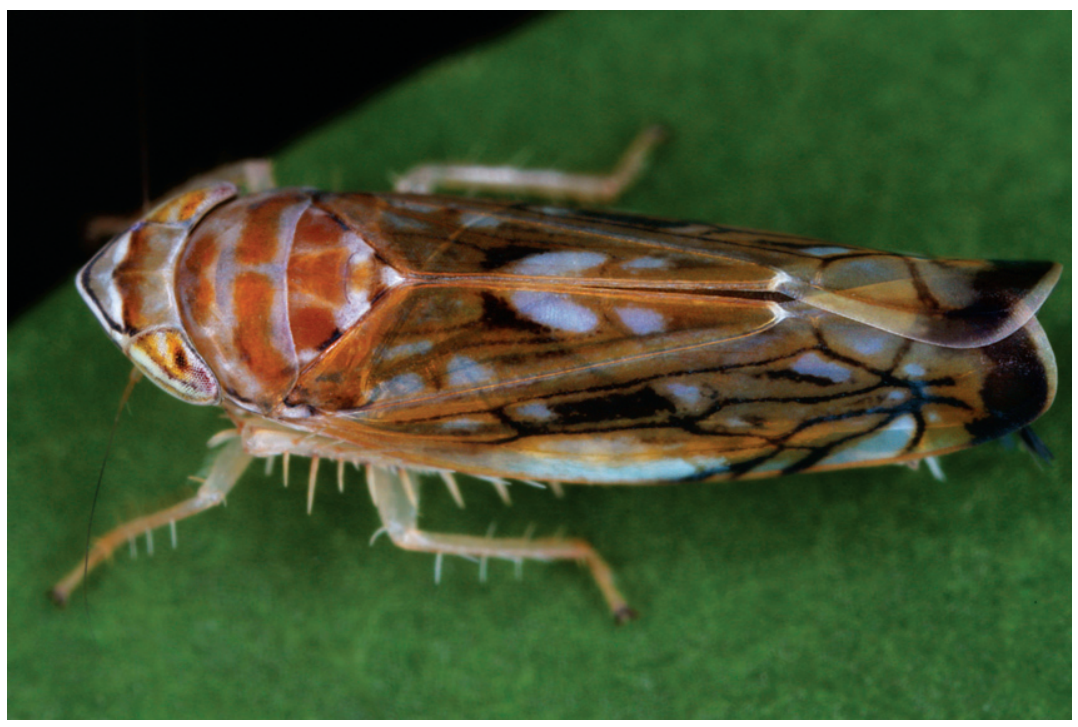

Credit: Gernot Kunz 


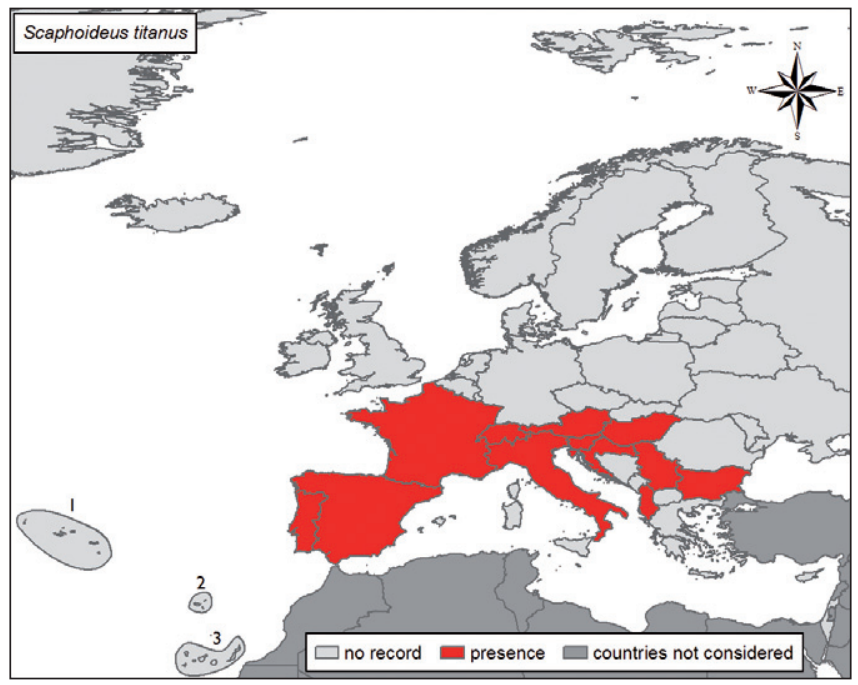

north- and eastward and was also found in Serbia (2003), southern Austria (2004), Bulgaria (2006), and southwestern Hungary (2006) (Map)

Pathways: Studies of the genetic structure of European populations has revealed longdistance translocations, most probably of eggs with grapevine propagation material. In addition the species spreads naturally, probably favoured by current climatic conditions.

Impact and management: Scaphoideus titanus is vector of "Flavescence dorée" (FD), a serious disease of grapevine, caused by the phytoplasma Candidatus Phytoplasma vitis, belonging to the elm yellow group $16 \mathrm{Sr}-\mathrm{V}$ subgroups $\mathrm{C}$ and D. Larvae acquire phytoplasmas by feeding on infected plants and after 4-5 weeks (in the third larval stage), they are able to transmit the disease to healthy plants. FD phytoplasma is reported from France, Italy, Portugal, Serbia, Slovenia, Spain, and Switzerland. Productivity of infected plants is greatly reduced by discolouration (yellowing) and desiccation.

\section{Selected references}

Bertin S, Guglielmino CR, Karam N, Gomulski LM, Malacrida A, Gasperi G (2006) Diffusion of the Nearctic leafhopper Scaphoides titanus Ball in Europe: a consequence of human trading activity. Genetica 131: 275-285.

Seljak G (2008) Distribution of Scaphoides titanus in Slovenia: its new significance after the first occurrence of grapevine "flavescence dorée". Bulletin of Insectology 61: 201-202.

Steffek R, Reisenzein H, Zeisner N (2007) Analysis of the pest risk from Grapevine flavescence dorée phytoplasma to Austrian viticulture. EPPO Bulletin 37: 191-203. 


\title{
14.41 - Pulvinaria regalis Canard, 1968 - Horse chestnut scale (Hemiptera, Coccidae)
}

\author{
Marc Kenis
}

Description and biological cycle: Adult scales are dark brown, flattish, round and about $4 \mathrm{~mm}$ in diameter. They are found on the edge of white egg masses on bark of trunks and branches (Photo). Nymphs on foliage are pale yellow and oval in shape. At outbreak density, P. regalis can be recognized by their white egg masses covering the trunk and the main branches in spring and in summer. This scale is univoltine. Crawlers hatch in May and June and move to leaves of the host tree. Nymphs feed on leaves until September/October and then migrate to twigs where they overwinter in the third instar. In spring, newly emerged females first feed, then move to the main branches and the trunk to lay eggs. Crawlers can be transported by wind. Host plant transportation is probably another important mode of dispersal. Although $P$. regalis is known to attack a high number of woody plants, heavy infestations occur mainly on Aesculus, Tilia and Acer in urban and suburban areas or along roads.

Native habitat (EUNIS code): Unknown.

Habitat occupied in invaded range (EUNIS code): G1 - Broadleaved deciduous woodland; I2 - Cultivated areas of gardens and parks.

Native range: Unknown
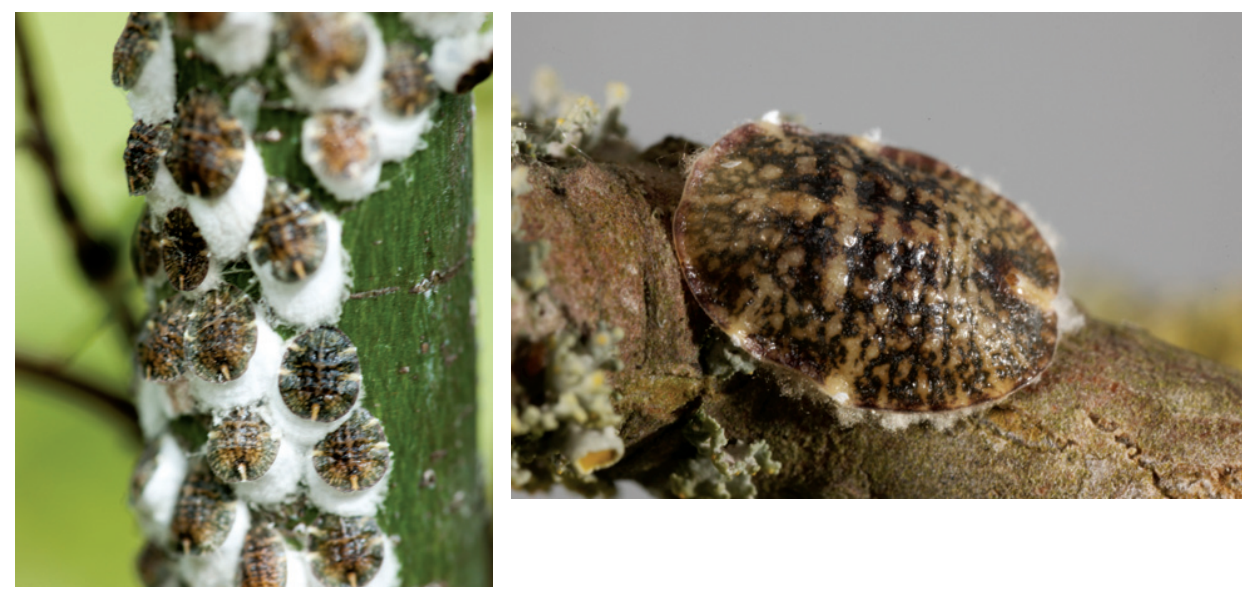

Credit: Chris Malumphy 


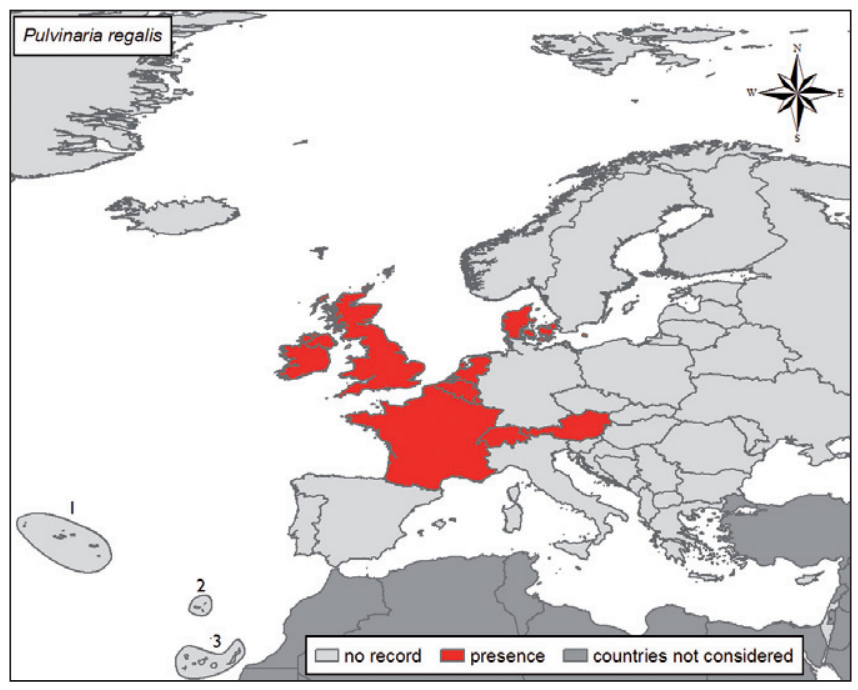

Introduced range: First found in London in 1964 and subsequently observed in France, Belgium, Netherlands, Germany, Ireland, Switzerland, Austria and Denmark (Map).

Pathways: Trade of ornamental plants.

Impact and management: Horse-chestnut scale does not kill trees, but outbreaks have a considerable impact on growth, particularly of young trees. This scale also causes aesthetic damage to ornamental trees. Additionally, it produces high quantities of honeydew that may become a nuisance in urban areas. Occurrence and incidence of the scale in natural habitats is unclear, and its interaction with native fauna is not known. Use of insecticides is possible, but difficult in urban areas. In spring, egg masses on trunks and branches can be washed off with water using a high-pressure cleaner. On small plants, mature scales and their eggs can be scraped or wiped from the stems.

\section{Selected references}

Hippe C, Frey JE (1999) Biology of the horse chestnut scale, Pulvinaria regalis Canard (Hemiptera: Coccoidea: Coccidae), in Switzerland. Entomologica 33: 305-309.

Jansen MGM (2000) The species of Pulvinaria in the Netherlands (Hemiptera: Coccidae). Entomologische Berichten 60: 1-11.

Speight MR. The impact of leaf-feeding by nymphs of the horse chestnut scale, Pulvinaria regalis Canard (Hom.: Coccidae), on young host trees. Journal of Applied Entomology 112: 389-399. 


\subsection{2 - Leptoglossus occidentalis Heidemann, 1910 - Western Conifer Seed Bug (Heteroptera: Coreidae)}

\section{Wolfgang Rabitsch}

Description and biological cycle: Large coreid true bug, reddish brown with a white zig-zag band on the forewing and a characteristic leaf-like dilation on the hind tibia (Photo), average size of adults $18 \mathrm{~mm}$. Adults emerge from overwintering sites in late spring. Females lay up to 80 eggs in chains on conifer needles. Nymphs develop into new generation in late summer, one generation per year. Feeds on the young seeds or flowers of conifer species, with a preference for Pinaceae (Plinus spp., Pseudotsuga menziesii), but it was also observed on Picea, Cedrus, Abies and Juniperus. eptoglossus occidentalis overwinters in crevices or secret places under bark or other structures.

Native habitat (EUNIS code): G3 - Coniferous woodland; G3F - Highly artificial coniferous plantations.

Habitat occupied in invaded range (EUNIS code): G3 - Coniferous woodland; G3F Highly artificial coniferous plantations; I2 - Cultivated areas of gardens and parks.

Native range: Presumed to be west of the Rocky Mountains in North America, from British Columbia to Mexico.

Introduced range: Since the 1950s, the species spread eastward and reached the east coast of North America in the 1990s. First European records date from 1999 near Vicenza (northern Italy). Western conifer seed bug then spread rapidly in Europe and is known from Switzerland (2002), Slovenia, Spain (2003), Croatia, Hungary (2004), Austria (2005), Czech Republic, France, Germany, Serbia (2006), United Kingdom, Belgium, Netherlands, Slovak

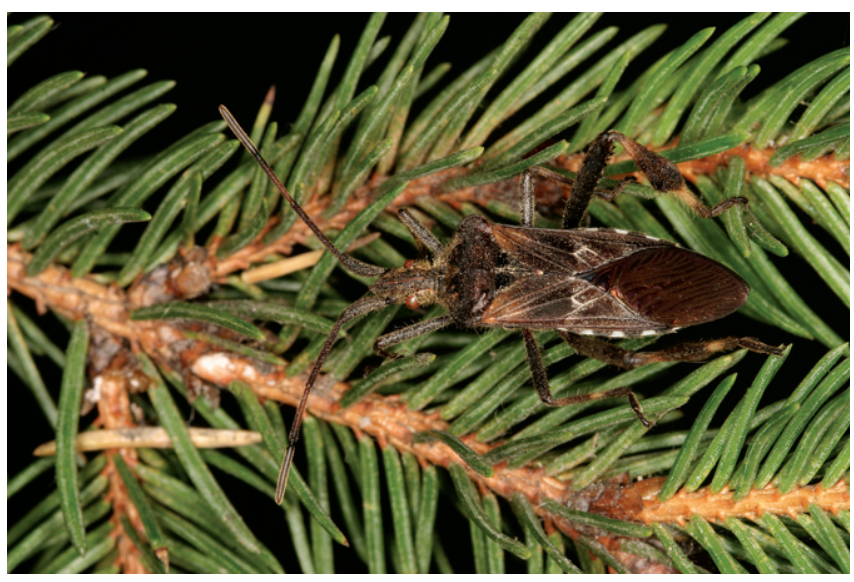

Credit:Wolfgang Rabitsch 


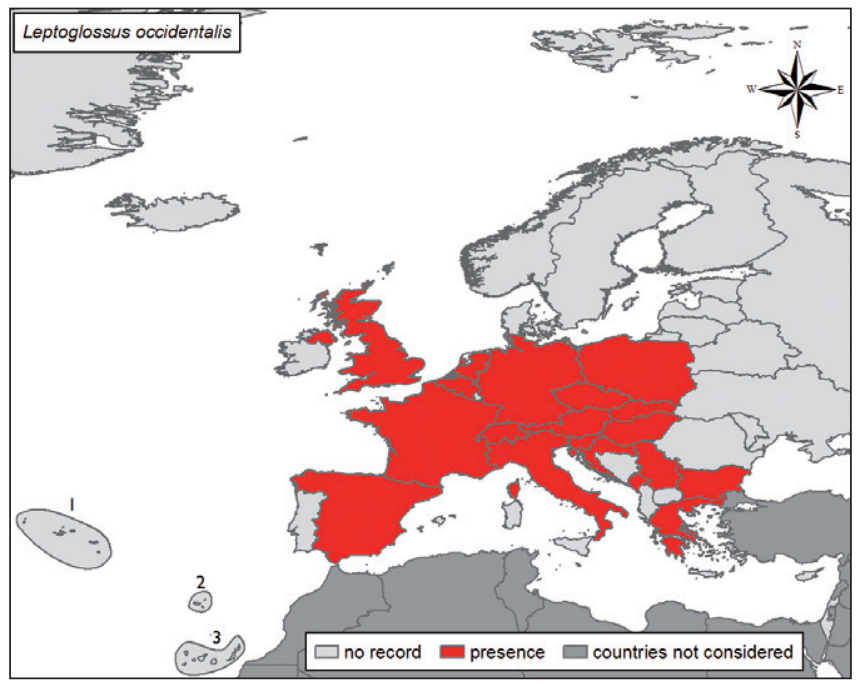

Republic, Poland (2007), Bulgaria, Montenegro and Greece (2008) (Map). In most countries, rapid within-country spread and increasing abundance has been observed. Recently, it was also introduced to Japan.

Pathways: The species is capable of flying over long distances, but also is translocated as egg, nymph or adult with its host plant (conifers).

Impact and management: Enters buildings in large numbers in autumn and so becomes a nuisance. Feeding on conifers causes reduction of seed fertility, and the species is regarded as pest in the native range. Although no economic impact has yet been measured in Europe, first observations tend to show that it may largely decrease the potential of regeneration of conifers in both seed orchards and natural pine stands. Mechanical exclusion is recommended to avoid public nuisance.

\section{Selected references}

Bernardinelli I, Zandigiacomo P (2001) Leptoglossus occidentalis Heidemann (Heteroptera, Coreidae): a conifer seed bug recently found in northern Italy. Journal of Forestry Science, 47: 56-58.

Ishikawa T, Kikuhara Y (2009) Leptoglossus occidentalis Heidemann (Hemiptera: Coreidae), a presumable recent invader to Japan. Japanese Journal of Entomology (New Series) 12: 115116.

Lis JA, Lis B, Gubernator J (2008) Will the invasive western conifer seed bug Leptoglossus occidentalis Heidemann (Hemiptera: Heteroptera: Coreidae) seize all of Europe? Zootaxa 1740: 66-68. 


\subsection{3 - Aspidiotus nerii (Bouché, 1833) (= A. hederae (Vallot, 1829)) - Oleander scale (Hemiptera, Diaspididae)}

Katalin Tuba and Ferenc Lakatos

Description and biological cycle: Adult female covered with a scale that is $1.5-2.0 \mathrm{~mm}$ in diameter, nearly circular and flat, yellowish white with a yellow or gold central part. Female body bright yellow. Wings, legs, and eyes absent. Scale cover of male white, oval, translucent and smaller, and more elongate than female. Adult males winged. Highly polyphagous species; > 200 host species recorded including Nerium oleander, Acer spp., Olea europaea, Populus spp. Ribes spp. and Vitis vinifera. Attacks and can wholly cover leaves, bark and the fruits (Photo-Colony on a palm leaf). Reproduction is either sexual (A. nerii nerii) or parthenogenetic (A. nerii unisexualis). The sexual population has higher fecundity and faster development than the parthenogenetic one. There are two or three generations per year depending on climatic conditions. Development time is about 30-35 d influenced by the sex, temperature, humidity, and rainfall. Each female lays a total of 100-150 eggs under the scale of the female, where they develop. The settled female nymph moults twice, the males four times. Adult females remain under scale throughout their life. Males became winged after the second moult, but their flight ability is limited. Male lifespan is only a few hours.

Native habitat (EUNIS code): G- Woodland and forest habitats and other wooded land; I- Regularly or recently cultivated agricultural, horticultural and domestic habitats.

Habitat occupied in invaded range (EUNIS code): G1 - Broadleaved deciduous woodland; I8: Part of agricultural land and artificial landscapes.

Native range: Afrotropical region.

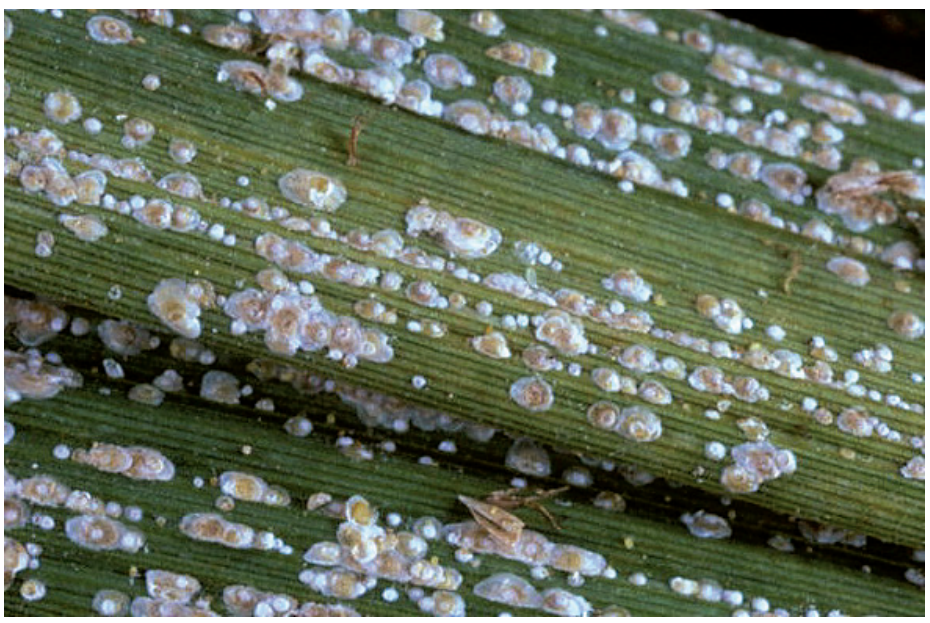

Credit: Claude Bénassy/INRA 


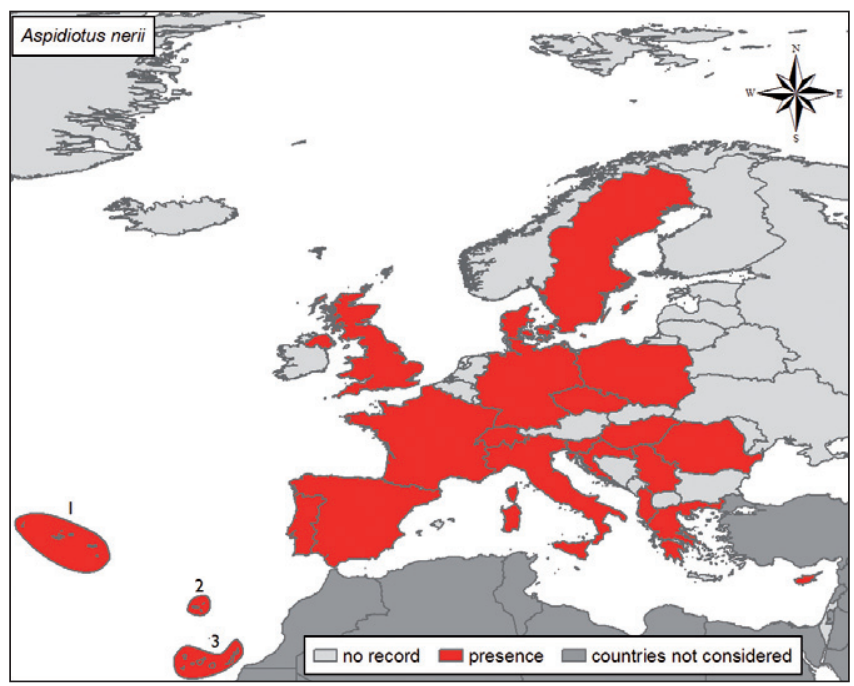

Introduced range: Nowadays with worldwide distribution, occurring especially in tropical and subtropical zones. First record in Europe from Italy in 1829. At present, the oleander scale is observed in most of Europe (Map) but in cold areas, occurs only in greenhouses and indoors.

Pathways: Trade of ornamental plants. The wide geographical distribution of this pest is primarily due to human activities. The first instar, the only nymphal stage with legs, is active and responsible for short-distance dispersal.

Impact and management: : Aspidiotus nerii is particularly important where aesthetic value of the crop is high, like cut flowers, ornamentals in gardens, nurseries, under glass and indoors. After heavy infestation in olive orchards, quality and quantity reduces. Economically important on other mediterranean forest tree species too. Both adults and nymphs cause damage. Mechanical, chemical and biological control is used to reduce damage. Nowadays, biological control plays the most important role, especially in greenhouses. Natural enemies have already adapted to the species: parasitoids, e. g. Aphytis chilensis (attacking nymphs and adults in Europe, the Middle East, Africa, America and Australia), Encarsia aurantii (South America), and also predators, e.g. Aleurodothrips fasciapennis (attacking eggs, nymphs, adults), Chilocorus circumdatus (attacking nymphs and adults) and Hemisarcoptes coccophagus (attacking all stages, except eggs).

\section{Selected references}

Alexandrakis V, Bénassy C (1981) Experiment in biological control on olive in Crete using Aphytis melinus DeBach (Hym. Aphelinidae), parasite of Aspidiotus nerii Bouché (Hom. Diaspididae). Acta Oecologica, Oecologia Applicata 2: 13-25.

Gerson U, Hazan A (1979) A biosystematic study of Aspidiotus nerii Bouché (Homoptera: Diaspididae), with the description of one new species. Journal of Natural History 13: 275 - 284. Longo S, Marotta S, Pellizzari G, Russo A, Tranfaglia A (1995) An annotated list of the scale insects (Homoptera: Coccoidea) of Italy. Israel Journal of Entomology 29: 113-130. 


\title{
14.44 - Diaspidiotus perniciosus (Comstock, 1881) - San José scale (Hemiptera: Diaspididae)
}

\author{
Marc Kenis
}

Description and biological cycle: Female is grey, circular and about $2 \mathrm{~mm}$ in diameter (Photo left-female with scale turned upside down to show the body colour). Male has only forewings present. Larvae highly variable, depending on stage and sex, white to black, round to elongate, and fixed scales or little mobile yellow organisms (Photo left-young nymphs pointed with arrow). In Europe, two to four generations per year, depending on climatic conditions. In cold climates, the winter is usually spent in the first larval stage. Development starts in early spring. Females become adult after the second moult and gradually increase in size. Males have two larval instars, a prepupal and a pupal stage. Males are winged and fly, but lack mouthparts, whereas females remain stationary and feed. Females are viviparous and produce about 100 larvae, 30-40 d after copulation. First instar crawls to find new host tissues. Then, it attaches itself and secretes a waxy substance forming the scale cover. Diaspidiotus perniciosus is a highly polyphagous species. The main hosts are apples, peaches, pears (Photo right-change in epidermis colour of a damaged pear), plums and Rubus.

Native habitat (EUNIS code): G1- Broadleaved deciduous woodland; I- Regularly or recently cultivated agricultural, horticultural and domestic habitats.

Habitat occupied in invaded range (EUNIS code): G1- Broadleaved deciduous woodland; I1- Arable land and market gardens; I2- Cultivated areas of gardens and parks; J100glasshouses.

Native range: East Asia.

Introduced range: First introduced into California in the $19^{\text {th }}$ century, from whence it spread to the whole North American continent. It is also present in many Asian, African and South American countries, as well as in New Zealand and Australia. First discovered in Hun-

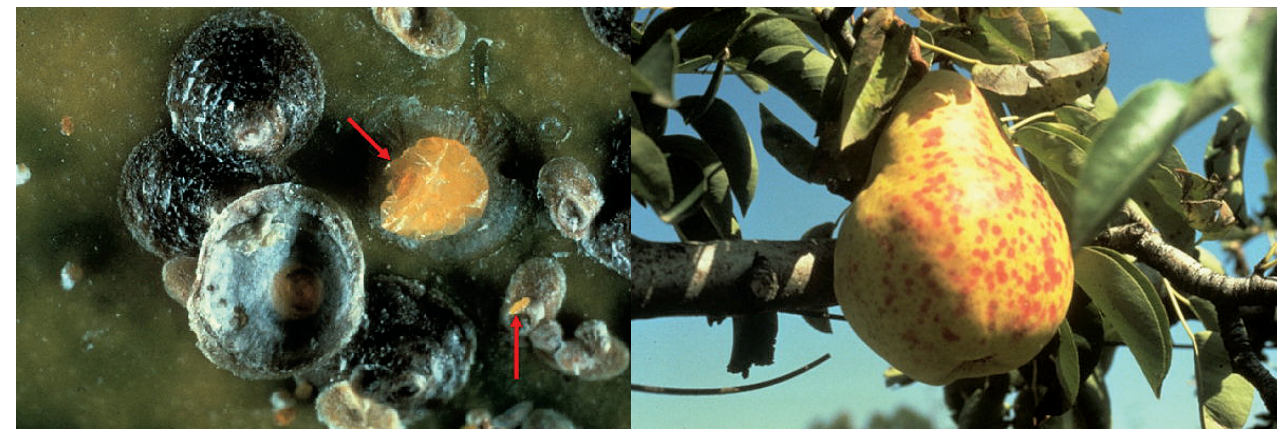

Credit: Rémi Coutin/ OPIE (left), Claude Bénassy/ INRA (right) 


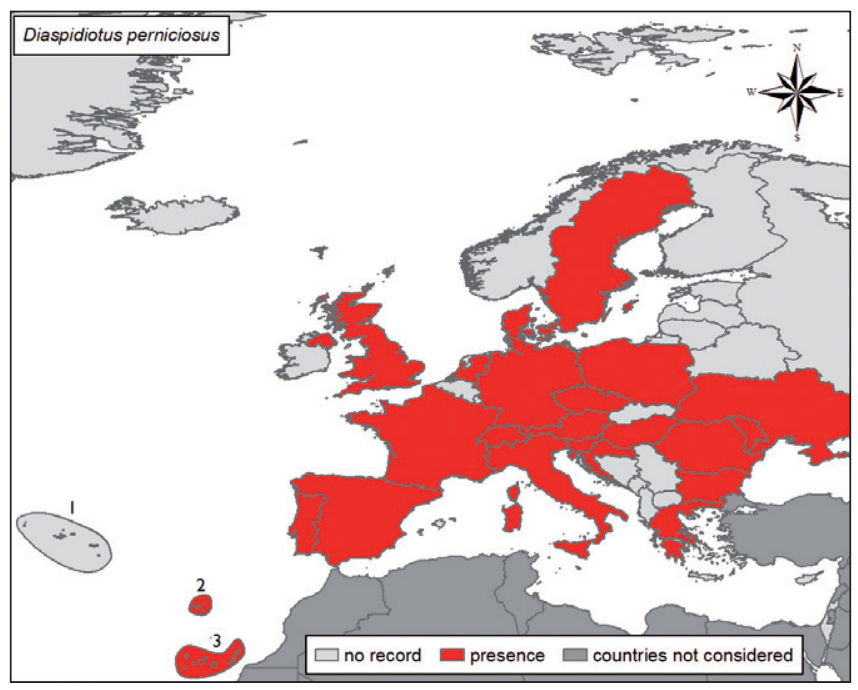

gary and Italy in 1928 and now present in most European countries (Map) although in many of them, it has not yet reached its potential distribution.

Pathways: International spread probably occurs through human-mediated transport of planting material of trees and shrubs, or fruits. The crawling first instar larvae are the main dispersal stage and can be carried a few kilometres by wind. Adult males, but not females, can also be carried by wind.

Impact and Management: Various young host plant tissues are affected. Attacks occur on wood mainly, but also on leaves and fruits. The insect injects toxic saliva, causing localized discolouration. San José scale can kill a young tree in 2-3 years in the absence of control. Older trees are weakened and growth is reduced, as well as fruit production and quality. This is considered a serious orchard pest in several European countries, reducing growth, fruit quality and marketability.

Mineral oil can be applied in winter against overwintering stages, whereas pesticides during the growing season. Sex pheromone traps are used to monitor the timing and level of attack. Biological control with the aphelinid wasp Encarsia perniciosi has been carried out in several regions, with varying degrees of success.

\section{Selected references}

Kosztarab M, Kozár F (1988) Scale insects of Central Europe. Budapest, Hungary: Dr. W. Junk Publishers. 456 pp.

Mani E, Schwaller F, Baroffio C, Hippe C (1995) Die San-José-Schildlaus in der deutschen Schweiz: Wo stehen wir heute? Schweizerische Zeitschrift für Obst- und Weinbau 131: 264-267. Melis A (1943) Contributo alla conoscenza dell'Aspidiotus pernicious. Redia 29: 1-170. 


\title{
14.45 - Pseudaulacaspis pentagona (Targioni-Tozzetti, 1886) - Mulberry scale (Hemiptera: Diaspididae)
}

\author{
Katia Trencheva
}

Description and biological cycle: Adult female cover is convex, circular white (Photo- Encrustation on a branch of peach); shed skins usually sub-central, yellowish orange. Male cover smaller, felted, white, elongate, sometimes with slight median carina completely enclosing developing male; shed skin white, sometimes tinged with yellow. Body of adult female light yellow, eggs of male white, that of females yellow or pink. Mulberry scale reproduces sexually, with two to five generations per year depending on climate. It has three generations per year in Bulgaria, where overwintering occurs as a fertile female. In the USA, it can also overwinter as adult females or as eggs. Females each lay about 100 eggs, which hatch 3-5 days after oviposition.

Native habitat (EUNIS code): G1- Broadleaved deciduous woodland; I- Regularly or recently cultivated agricultural, horticultural and domestic habitats.

Habitat occupied in invaded range (EUNIS code): G1- Broadleaved deciduous woodland; I1- Arable land and market gardens; I2- Cultivated areas of gardens and parks; J100glasshouses.

Native range: East Asia.

Introduced range: Accidentally introduced to Italy in 1886, then recorded in most countries of Southern and Central Europe and in the Atlantic islands (Map). Nowadays, it is one of the best examples of the northward expansion of insects in central Europe where it has colonized both cultivated and natural habitats, primarily occurring on bark and fruit of various trees and shrubs, occasionally on leaves. Also introduced in Africa, Australia, New Zealand, southern Central America and many Pacific Islands.

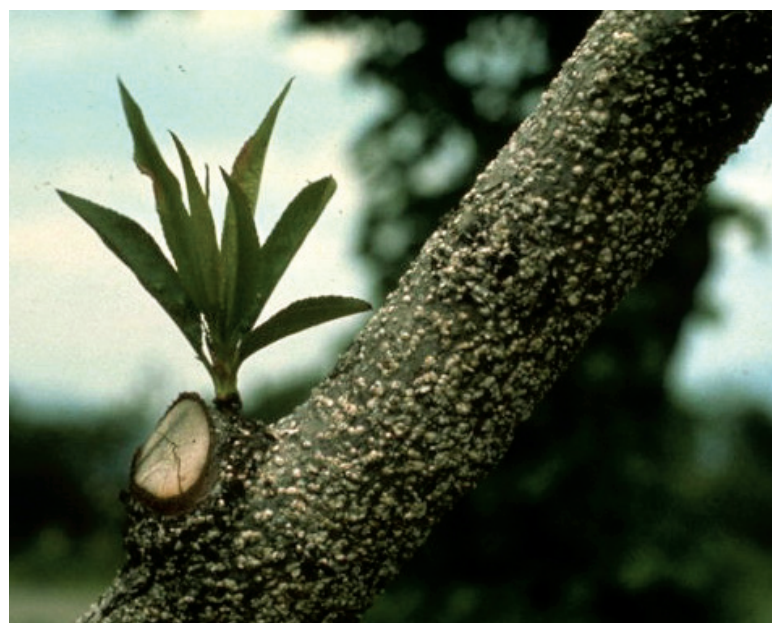




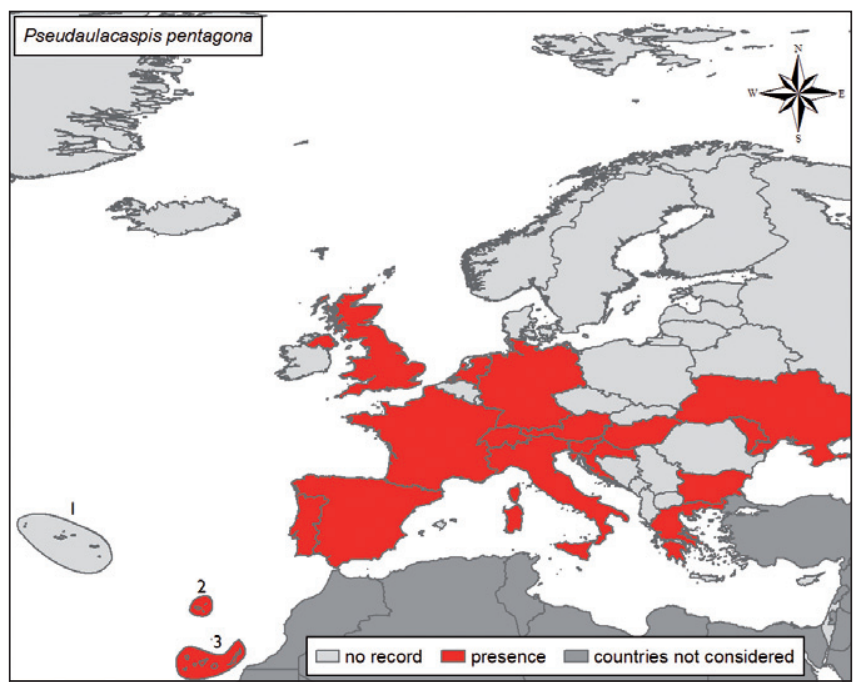

Pathways: Trade in plants and plant products. Mulberry scale can also be transported by wind and by birds.

Impact and management: Most serious problems are caused in areas of accidental introduction in the absence of its natural regulators. The efficiency of natural enemies is reduced in urban areas by pollution. Consequently, $P$. pentagona can cause severe damage to ornamental plants in towns and cities. It is particularly destructive on flowering cherry, mulberry, peach and other deciduous fruit trees. In Europe, outbreaks have occurred in many countries, including Hungary, Switzerland, France, Greece and Bulgaria. Scale insects are difficult to control because the waxy or cottony covering serves as a protective barrier to traditional contact insecticides. However, a pest management program that incorporates natural, mechanical, and/or chemical controls should provide satisfactory control of most scales. Pheromone traps are used for detection in newly infested regions, especially in Europe. Colour and sticky traps have also been developed to monitor the flight and dispersal of males. Natural enemies, particularly the parasitoid Encarsia berlesei, can be effective control agents. Chemical control may not be advisable for orchards, since the natural enemies of $P$. pentagona can be killed, causing local outbreaks.

\section{Selected references}

Kozár F, Sheble DAF, Fowjhan MA (1995) Study on the further spread of Pseudaulacaspis pentagona (Homoptera: Coccoidea: Diaspididae) in Central Europe. Israel Journal of Entomology 29: 161-164.

Targioni Tozzetti A (1886) (1885) Sull'insetto che danneggia I gelsi. Rivista di bachicoltura 18: 1-3. Watson GW (2002) Pseudaulacaspis pentagona. In: Arthropods of Economic Importance. Diaspididae of the world. World Biodiversity database. http://nlbif.eti.uva.nl/bis/diaspididae. php. 


\title{
14.46 - Metcalfa pruinosa (Say, 1830) - Citrus Flatid Planthopper (Hemiptera: Flatidae)
}

\author{
Milka M. Glavendekić
}

Description and biological cycle: Adult usually $5.5-8 \mathrm{~mm}$ long and $2-3 \mathrm{~mm}$ wide. Adults vary from brown to grey. Forewings and the body are covered with a soft white powder, giving them a bluish tone (Photo left). Larvae white, less than twice as long as wide, when mature about $4 \mathrm{~mm}$ long (Photo right). The species is univoltine. Highly polyphagous, recorded on 330 woody and herbaceous plant species in 78 plant families in Europe. Eggs laid singly in splits under bark of host plant during late summer and early autumn, where they overwinter and hatch during spring of the following year between late May and early June to mid-July. First adults of the new generation appear from mid-July and live until early November.

Native habitat (EUNIS code): F5 - semi-arid and subtropical habitats

Habitat occupied in invaded range (EUNIS code): G1 - Broadleaved deciduous woodland; I1 - Arable land and market gardens; I2 - Cultivated areas of gardens and parks; X16 Land sparsely wooded with mixed broadleaved and coniferous trees; X25 - Domestic gardens of villages and urban peripheries.

Native range: Eastern North America.

Introduced range: Since it was first recorded in north-eastern Italy in 1979, citrus flatid planthopper has spread in the Mediterranean region, as well as to Central- and South-East Europe (Map).

Pathways: Trade appears to be the most likely pathway for introduction, on imported commodities such as nursery stock, both ornamentals and vegetables from infested areas.

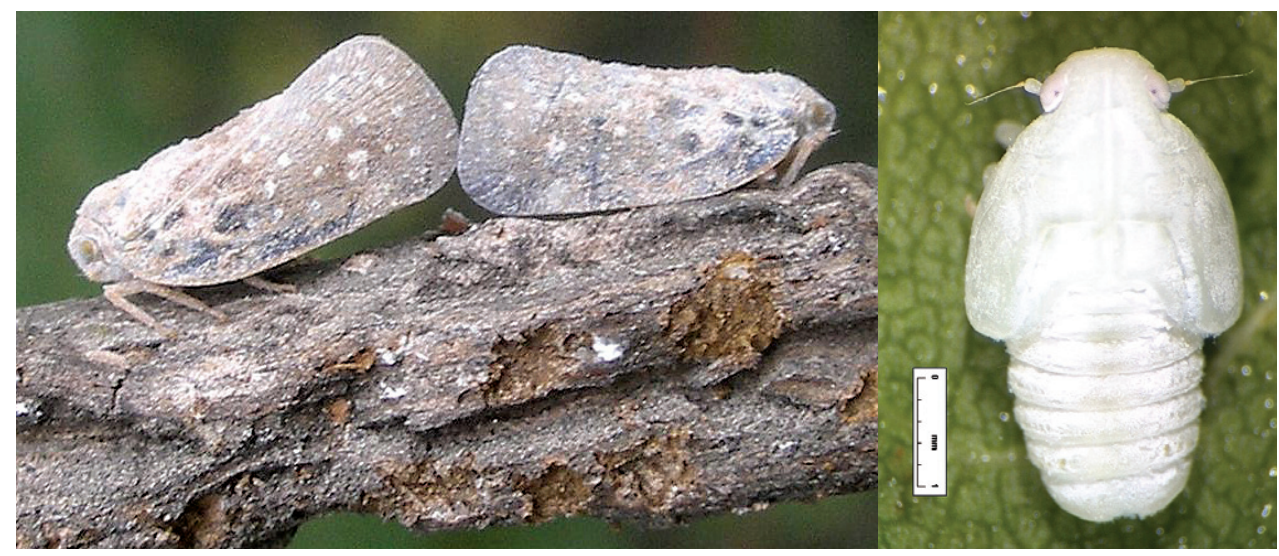

Credit: LNPVI Montpellier Station 


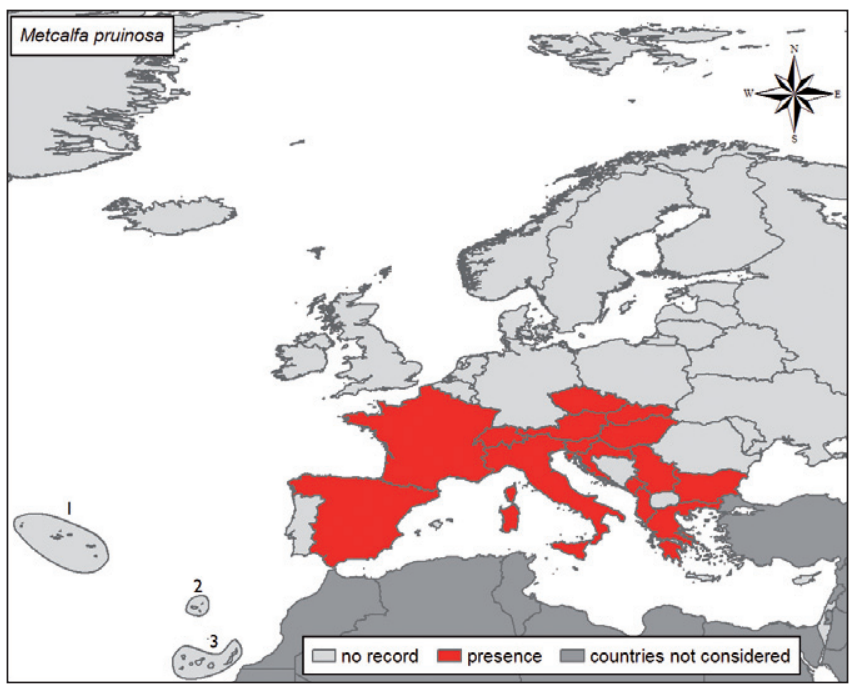

Spread mostly passive through eggs laid into the bark of plants. Adults can also spread occasionally, attached to commodities or via transport by human activity.

Impact and management: Considered as one of the most prolific pests for its ability to infest a wide variety of plant species in agricultural, forest and urban ecosystems. Metcalfa pruinosa sucks the sap from small diameter stems, but the damage is usually minor. There is evidence in Italy that $M$. pruinosa is infected by phytoplasma*, which could induce diseases on fruit trees. Oviposition injuries sometimes kill seedlings. Buds with deposited eggs could be frozen during winter. The most severe damage in Europe is caused by the secretion of honeydew which is colonized by sooty-mould fungus thus hindering photosynthetic capacity of the plant. High population could have a nuisance effect on tourism in some places. Mechanical control is effective on young plants by pruning and destroying shoots that contain oviposition punctures. Chemical control is possible in juvenile stages, but less effective against adults. Biological control includes the use of a dryinid wasp predator-parasitoid Neodryinus typhlocybae (Ashmead) (Hymenoptera: Dryinidae), which is introduced in Italy in 1994.

\section{Selected references}

Lucchi A (Ed) (2000) La Metcalfa negli ecosistemi italiana. Firenze: Agenzia Regionale per lo Sviluppo e l'Innovazione nel settore Agriocolo-forestale.163 pp.

Orosz A, Der Z (2004) Beware of the spread of the leafhopper species Metcalfa pruinosa (Say, 1830). Novenyvedelem 40: 137-141.

Trenchev G, Ivanova I, Nicolov P, Trencheva K (2007) Metcalfa pruinosa (Say, 1830) (Homoptera, Flatidae) a species new to the Bulgarian fauna. Plant Science 34: 195-198. 


\subsection{7 - Nysius huttoni White, 1878 - Wheat bug (Hemiptera: Lygaeidae)}

\section{Wolfgang Rabitsch}

Description and biological cycle: Small lygaeid true bug, brown, with characteristic dorsal erect pubescence (Photo-adults mating). Average adult size $3.5 \mathrm{~mm}$. Wing morphs comprise macropters, submacropters and brachypters; macropters are capable of flight over some distances; adults hibernate and two generations are developed per year in western Europe. Polyphytophagous species feeding on different weeds and crops (e.g. Brassica, Capsella, Chenopodium, Hieracium, Medicago, Polygonum, Rumex, Silene, Senecio, Trifolium and Triticum), attaining pest status in its native area.

Native habitat (EUNIS code): B - Coastal habitats; E - Grassland and tall forb habitats; I - Regularly or recently cultivated agricultural, horticultural and domestic habitats.

Habitat occupied in invaded range (EUNIS code): I - Regularly or recently cultivated agricultural, horticultural and domestic habitats. In Europe, found in dry and warm sites, waste grounds, roadsides, sparsely vegetated sandy soils, and abandoned fields. The presence of acrocarpous mosses seems necessary.

Native range: New Zealand.

Introduced range: First recorded 2002 in the Netherlands, 2003 in Belgium and subsequently found at the French/Belgian border. In 2007 and 2009 it was found in Great Britain

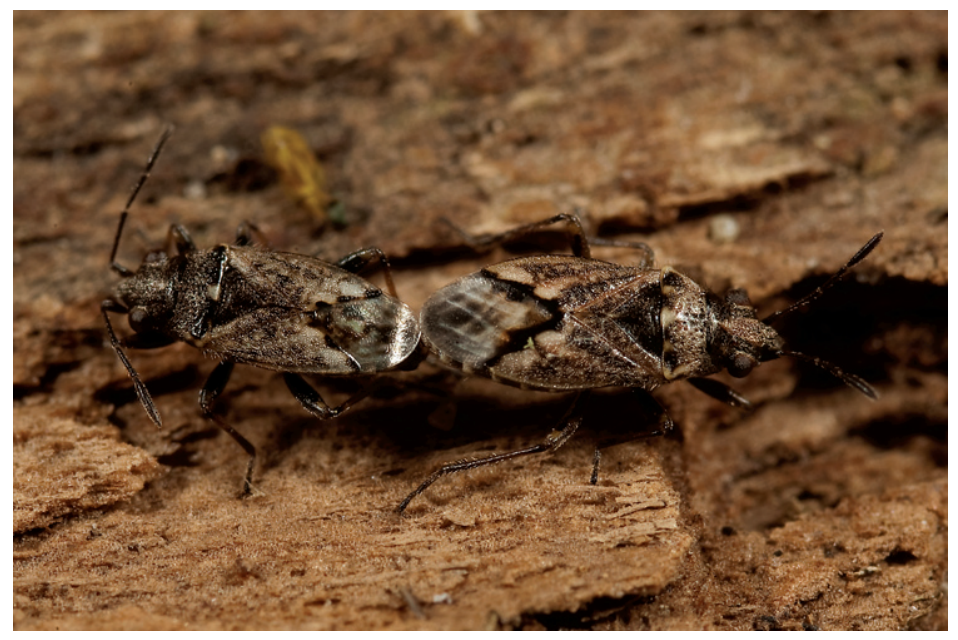

Credit: R. Kleukers 


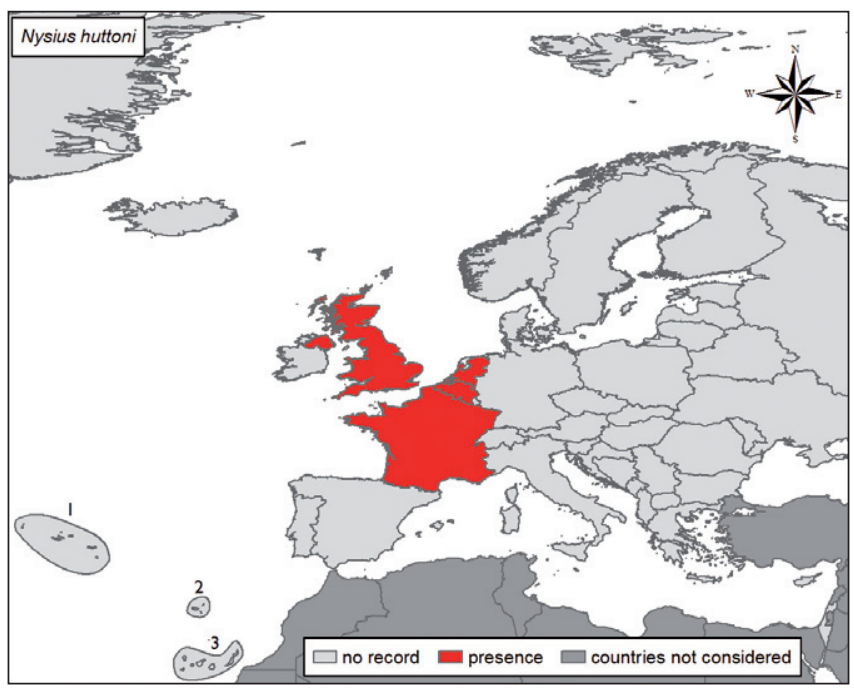

(East Suffolk, North Essex) (Map). Nysius species are well known for their high abundances and effective dispersal strategies and it is expected that this species will further spread across Europe. Nysius huttoni currently is included in the EPPO Alert List. It has been intercepted on fruits in Australia and the United States.

Pathways: Unintentional introduction, probably with shipments

Impact and Management: $N$. huttoni is an economically important pest species in New Zealand, particularly when feeding on wheat and degrading gluten thus diminishing baking quality. Insecticides may be used, but no effective control treatment is known.

\section{Selected references}

Aukema B, Bruers JM, Viskens G (2005) A New Zealand endemic Nysius established in the Netherlands and Belgium (Heteroptera: Lygaeidae). Belgian Journal of Entomology 7: 37-43.

He XZ, Wang Q, Carpenter A (2003) Thermal requirements for the development and reproduction of Nysius huttoni White (Heteroptera: Lygaeidae). Journal of Economic Entomology 96: 1119-1125.

Smit JT, Reemer M, Aukema B (2007) Een invasie van de nieuw-zeelandse tarwewants Nysius huttoni in Nederland (Heteroptera: Lygaeidae). Nederlandse Faunistische Mededelingen 27: 51-70. 


\title{
14.48 - Stictocephala bisonia Kopp \& Yonke, 1977 - Buffalo treehopper (Hemiptera: Membracidae)
}

\author{
Wolfgang Rabitsch
}

Description and biological cycle: Medium-sized membracid treehopper, average adult body size 8-10 mm, adults bright green (Photo), larvae light grey-green with longitudinal row of spines and conical abdomen. Characteristic pronotum with buffalo-horn-like protrusions. Females lay batches of 5-12 yellow eggs in the bark of host plants by cutting small punctures. Overwinters as eggs, with adults of the new generation appearing in July, and one generation per year. Stictocephala bisonia is polyphagous on different herbs, shrubs and trees (e.g. Rosa, Malus, Pyrus, Prunus, Cornus, Crataegus, Populus, Ulmus, Coronilla, Melilotus, Solidago and Medicago).

Native habitat (EUNIS code): F9 - Riverine and fen scrubs; I - Regularly or recently cultivated agricultural, horticultural and domestic habitats.

Habitat occupied in invaded range (EUNIS code): F9 - Riverine and fen scrubs; I - Regularly or recently cultivated agricultural, horticultural and domestic habitats; FA - Hedgerows; FB - Shrub plantations; E - Grassland and tall forb habitats. A preference for moist and wet riverine habitats, woody margins and tall herb stands, but it also can be found in dry meadows and agricultural land.

Native range: North America, widely distributed from Canada to Mexico.

Introduced range: accidentally introduced to Europe in the $20^{\text {th }}$ century (first documented record: 1912 in former Hungary) and is present now in almost all countries (Map). It also spread to North Africa and Central Asia.

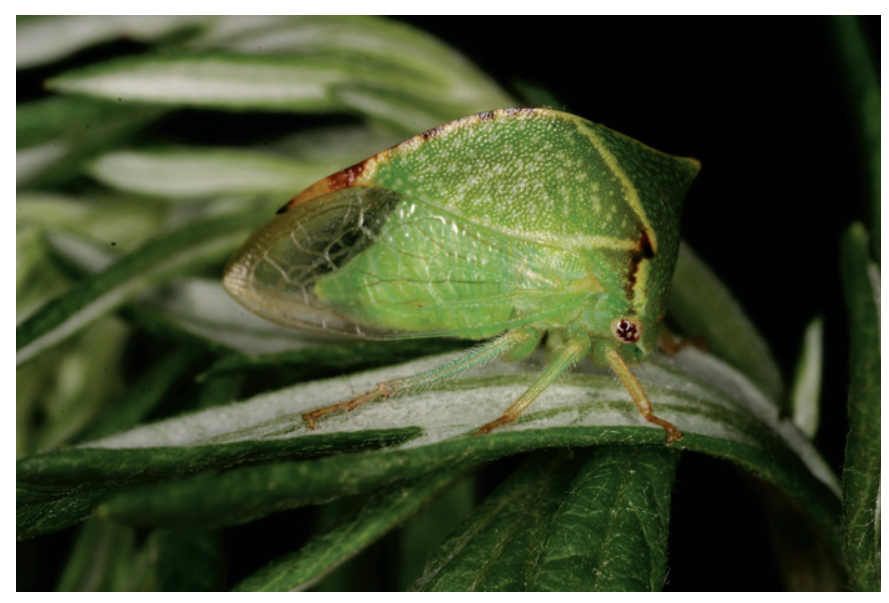

Credit: Wolfgang Rabitsch 


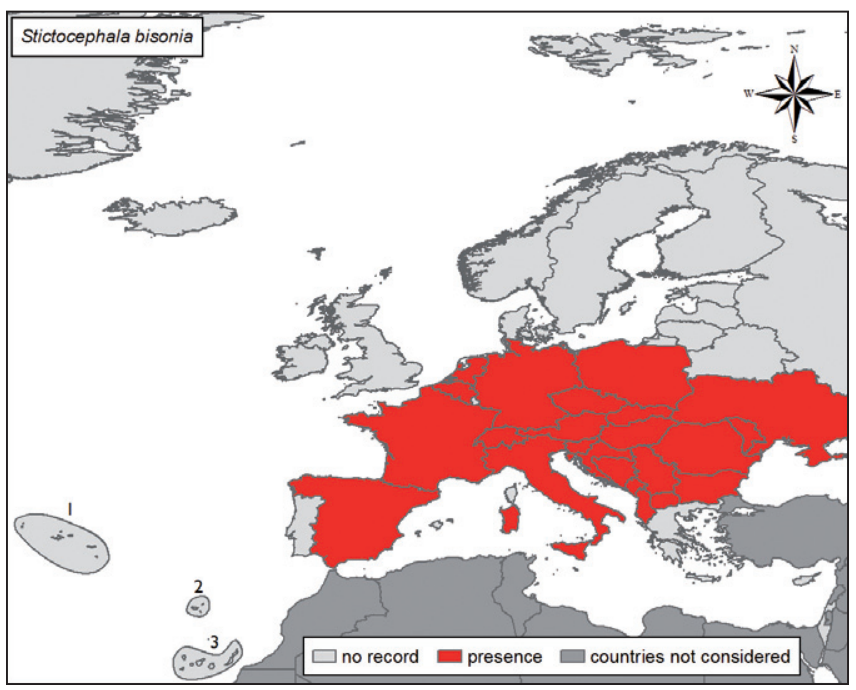

Pathways: Long-distance dispersal of eggs with infected tree-seedlings; adults capable of flight.

Impact and management: Females deposit their eggs in shrub and tree stems, which usually die above the insertion slits and also provide entry for pathogens; this may cause economic loss in orchards and vine cultures. Feeding activity on fruit trees and in vineyards may cause discolouration and wrinkling of the leaves and malignant growth of twigs; severely scarred branches should be pruned out. Application of insecticides usually is not effective; release of an introduced Nearctic parasitoid braconid (Polynema striaticorne) successfully controlled Stictocephala populations in Italy, where the braconid established and spread subsequently.

\section{Selected references}

Alma A, Arno C, Vidano C (1987) Particularities on Polynema striaticorne as egg parasite of Stictocephala bisonia (Rhynchota, Auchenorryncha). Proceedings $6^{\text {th }}$ Auchenorryncha Meeting, Turin, Italy, 7-11 September 1987, 597-603.

Fursov VN (1994) New data on Polynema striaticorne (Hymenoptera, Mymaridae) and its cicada host Stictocephala bisonia (Homoptera, Membracidae). Vestnik Zoologii 2: 12-19.

Holzinger W, Kammerlander I, Nickel H (2003) The Auchenorrhyncha of Central Europe.

Vol. 1. Leiden: Brill. 674 pp.

Schedl W (1991) Invasion der Amerikanischen Büffelzikade (Stictocephala bisonia Kopp \& Yonke, 1977) nach Österreich (Homoptera, Auchenorrhyncha, Membracidae). Anzeiger für Schädlingskunde 64: 9-13. 


\subsection{9 - Halyomorpha halys (Stål, 1855) - Brown Marmorated Stink Bug (Heteroptera: Pentatomidae)}

\section{Wolfgang Rabitsch}

Description and biological cycle: Large pentatomid true bug, shield-shaped, mottled brown, size of adults $12-17 \mathrm{~mm}$; females lay egg clutches of up to 25 eggs on the underside of leaves. The species hibernates as adult, producing one generation per year and is regarded as a polyphagous horticultural pest, observed on over 60 host plants, including fruit and shade trees and other woody ornamentals (e.g. Acer, Buddleja, Citrus, Malus, Morus, Paulownia, Prunus, Pyrus and Rosa), vegetables and as an agricultural pest on various leguminous crops (e.g. soybean).

Native habitat (EUNIS code): G1 - Broadleaved deciduous woodland; I - Regularly or recently cultivated agricultural, horticultural and domestic habitats; X25 - Domestic gardens of villages and urban peripheries.

Habitat occupied in invaded range (EUNIS code): I2 - Cultivated areas of gardens and parks; X25 - Domestic gardens of villages and urban peripheries.

Native range: Asia (Japan, Korea, China, Taiwan).

Introduced range: Introduced to the east coast of USA since 1996, where it subsequently spread along the east coast south to South Carolina. In 2007, there were several records including nymphs from the area around Zürich in Switzerland, indicating established populations in Europe.

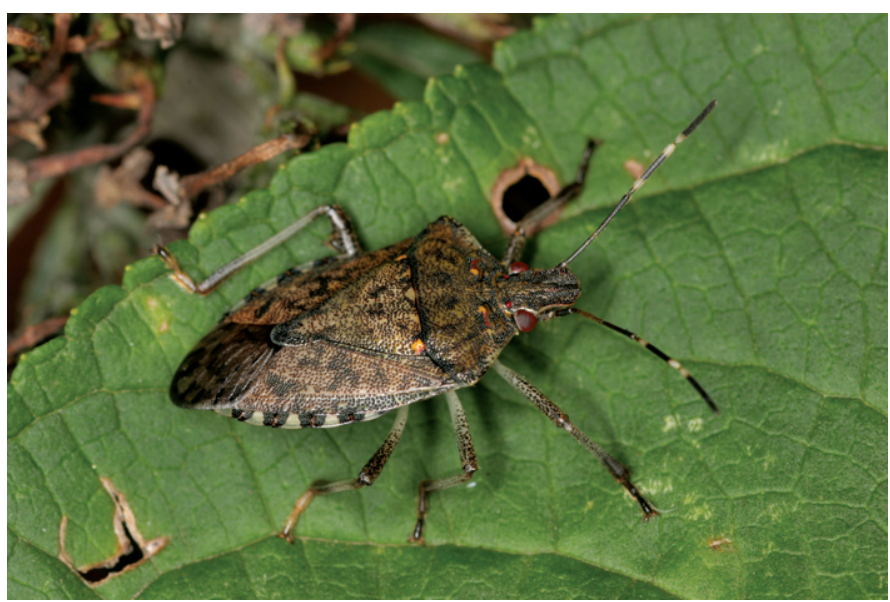

Credit: Beat Wermelinger 


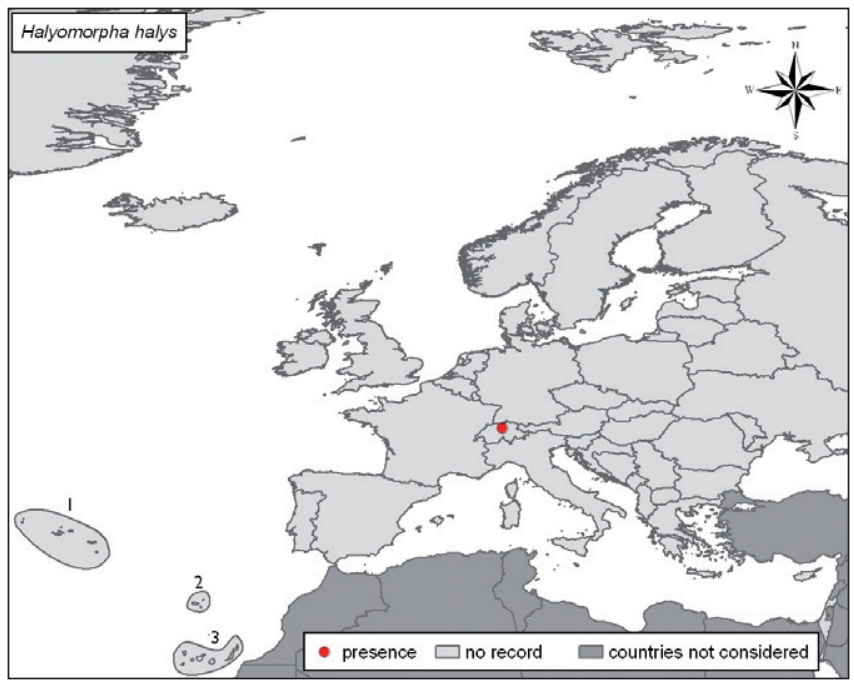

Pathways: Long-distance dispersal occurs as stowaways with goods and plant material. Adults are able to fly some distance.

Impact and management: Detrimental impacts on ornamentals (necrosis on leaves and fruits) has been observed. Brown marmorated stink bug is also known to be a vector of witches' broom, a phytoplasma* disease of Paulownia tomentosa, an East Asian ornamental tree introduced to Central Europe in 1834, which only recently established and spread in urban-industrial areas. In Asia and America, Halyomorpha halys causes a nuisance in households when seeking hibernation sites in large numbers in autumn. Mechanical exclusion and chemical control are suggested to control indoors pest problems.

\section{Selected references}

Hoebeke ER, Carter ME (2003) Halyomorpha halys (Stål), (Heteroptera: Pentatomidae) a polyphagous plant pest from Asia newly detected in North America. Proceedings of the Entomological Society of Washington 105: 225-237.

Wermelinger B, Wyniger D, Forster B (2008) First records of an invasive bug in Europe: Halyomorpha halys Stål (Heteroptera: Pentatomidae), a new pest on woody ornamentals and fruit trees. Mitteilungen der Schweizerischen entomologischen Gesellschaft 81: 1-8.

Gyeltshen J, Bernon G, Hodges A. Brown Marmorated Stink Bug, Halyomorpha halys Stål (Insecta: Hemiptera: Pentatomidae). http://edis.ifas.ufl.edu/in623. 


\title{
14.50 - Viteus vitifoliae (Fitch, 1855), Grape phylloxera (Hemiptera: Phylloxeridae)
}

\author{
Marc Kenis
}

Description and biological cycle: Small, globular, 1-1.8 mm long (Photo). Complex life cycle, which depends both on vine species or cultivars and the environment. Grape phylloxera has several generations per year and alternates between sexual and asexual generations, and between an aerial form causing galls on leaves, named gallicolae, and a root-feeding form, radicicolae. Viteus vitifoliae is a monophagous species restricted to some vine species of the genus Vitis. On the European grapevine, Vitis vinifera, the gallicolae form is rare, the radicicolae form persists parthenogenetically.

Native habitat (EUNIS code): G - Woodland and forest habitats and other wooded land; I- Regularly or recently cultivated agricultural, horticultural and domestic habitats.

Habitat occupied in invaded range (EUNIS code): I- Regularly or recently cultivated agricultural, horticultural and domestic habitats.

Native range: Eastern North America.

Introduced range: It was first recorded in Europe in 1860 in France. Nowadays, most grapevine-growing areas in Europe are invaded, except Cyprus, parts of Greece and some re-

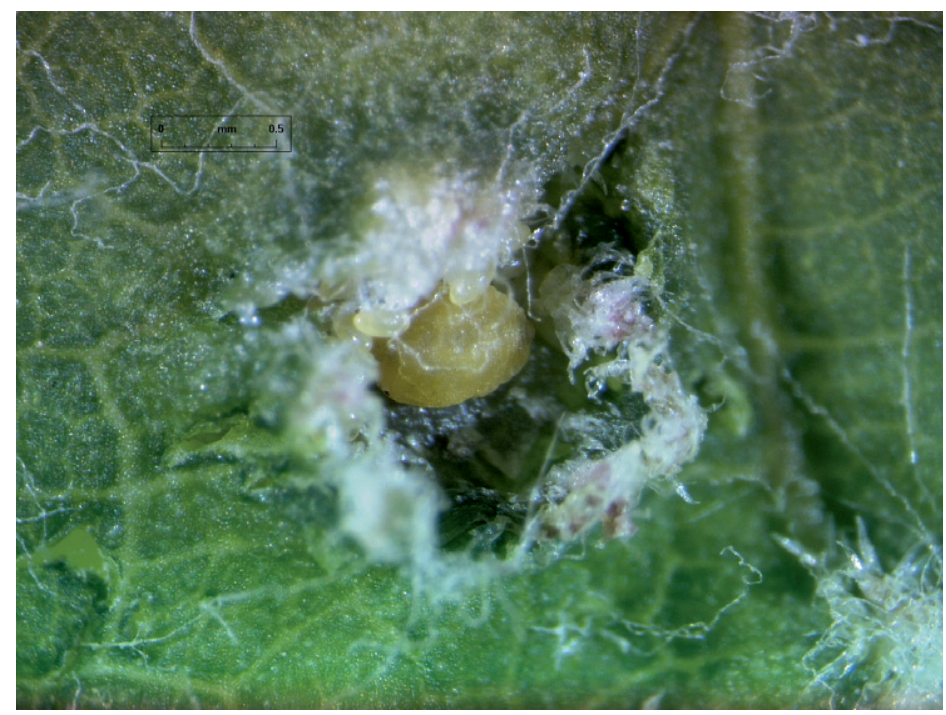

Credit: LNPVI Montpellier Station 


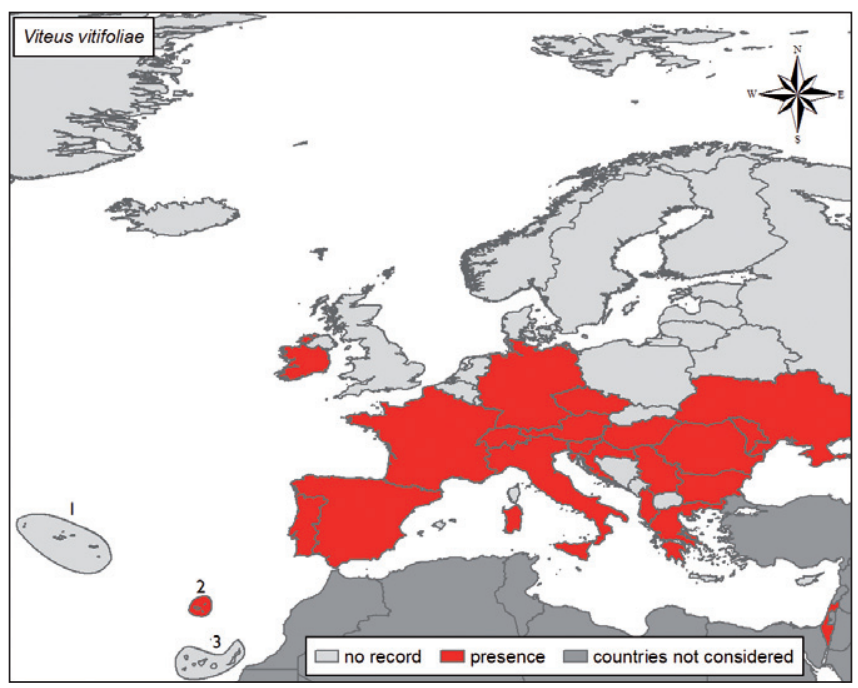

stricted areas in a few other countries (Map). The pest also spread to most major wine-producing areas, in Western North America, South America, South Africa and New Zealand.

Pathways: This aphid, particularly the radicicolae form, does not spread easily by itself and is mainly carried on grapevine plants.

Impact and management: The main damage is caused by radicicolae that feed on grapevine roots and are associated with secondary pathogens. In susceptible vine species and cultivars, they cause root rot, decrease plant vigour and, ultimately, kill the vines within 3-10 years. In the $19^{\text {th }}$ century, $V$. vitifoliae causes huge damage to vineyards and has endangered the European wine industry. In France alone, it caused the destruction of 1.2 million ha. The problem was solved by grafting European cultivars on less susceptible American rootstocks. Grape phylloxera is still the target of phytosanitary regulations in Europe and elsewhere, because some pest-free areas remain, where susceptible grape cultivars are cultivated on their own roots. In the last 30 years, the level of damage has occasionally increased in various countries, with the appearance of new biotypes that overcome the resistance of certain rootstock cultivars.

\section{Selected references}

CABI (2007) Crop Protection Compendium. CD-ROM. Wallingford, UK: CAB International. Forneck A, Walker MA, Blaich R (2001) An in vitro assessment of phylloxera (Daktulosphaira vitifoliae Fitch) (Hom., Phylloxeridae) life cycle. Journal of Applied Entomology, 125: 443-447. Granett J, Walker MA, Kocsis L, Omer AD (2001) Biology and management of grape phylloxera. Annual Review of Entomology, 46: 387-412. 


\subsection{1 - Corythucha arcuata (Say, 1832) - Oak lace bug (Heteroptera: Tingidae)}

\section{Wolfgang Rabitsch and Marc Kenis}

Description and biological cycle: Small tingid true bug, adults greyish to whitish with lacelike forewings, nymphs black with spines, adult body size $3 \mathrm{~mm}$. Differs from C. ciliata in forewing pigmentation. Adults hibernate in bark crevices. Females lay eggs on the leaf underside. Development from egg to adult takes 30-45 days, 2-4 generations per year. The species feeds on deciduous Quercus species and was also reported on Castanea sativa, and occasionally on Acer, Malus and Rosa species.

Native habitat (EUNIS code): G1 - Broadleaved deciduous woodland.

Habitat occupied in invaded range (EUNIS code): G1 - Broadleaved deciduous woodland; I2 - Cultivated areas of gardens and parks.

Native range: North America, east of the Rocky Mountains.

Introduced range: First record for Europe dates back to spring 2000, when the species was found in northern Italy (Lombardy, Piemont). In 2002, it was found in Turkey (Western Anatolia) and 2003 in southern Switzerland (Tessin). It subsequently expanded its range in

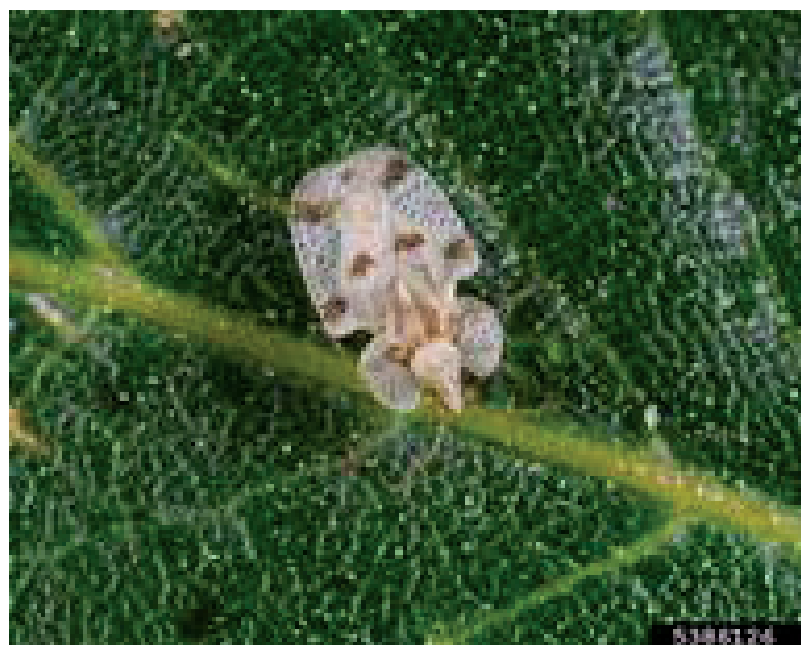

Credit:Joseph Berger, insectimages.org 


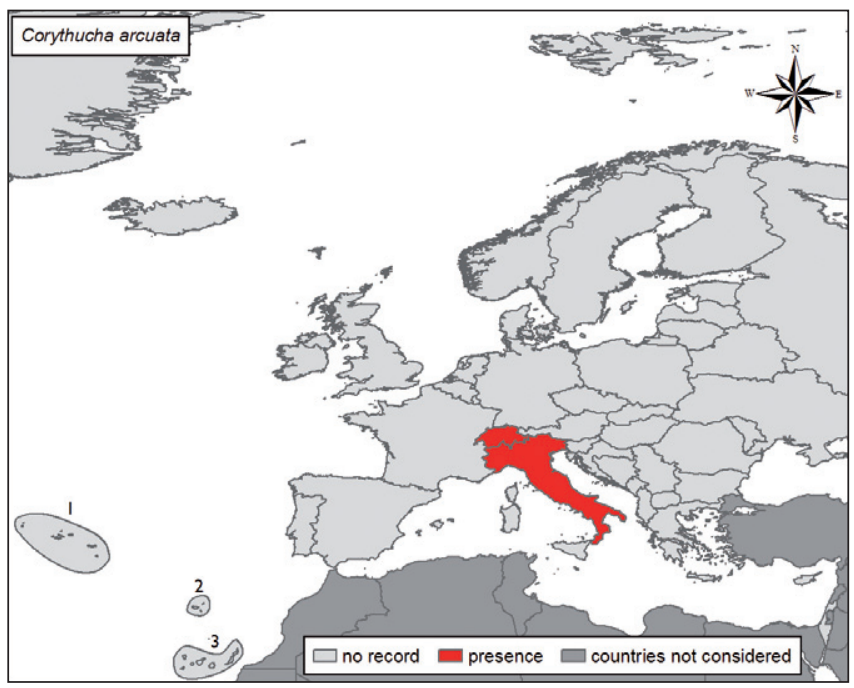

Italy and Switzerland and particularly in Turkey, where it has so far invaded an area of 28,000 $\mathrm{km}^{2}$. The oak lace bug is expected to further spread in Europe, where host plants occur.

Pathways: Long-distance dispersal occurs with human activity (introduction with oak plants); adults can fly and be spread by wind.

Impact and management: Corythucha arcuata may cause damage to the host trees (chlorotic discolouration, desiccation, premature leaf-fall and reduced photosynthetic activity). $C$. arcuata is not considered an important pest species in North America, likely due to control by natural enemies. Since these are missing in Europe, the environmental and economic impact in Europe is unknown, but potentially high.

\section{Selected references}

Bernardinelli I (2000) Distribution of Corythucha arcuata (Say) in northern Italy (Heteroptera, Tingidae). Redia 83: 157-162.

Bernardinelli I (2006) Potential host plants of Corythucha arcuata (Het., Tingidae) in Europe: a laboratory study. Journal of Applied Entomology 130: 480-484.

Forster B, Giacalone I, Moretti M, Dioli P, Wermelinger B (2005) The American oak lace bug Corythucha arcuata (Say) new to southern Switzerland. Mitteilungen der Schweizerischen Entomologischen Gesellschaft 78: 317-323. 


\subsection{2 - Corythucha ciliata (Say, 1832) - Sycamore lace bug (Heteroptera: Tingidae)}

\section{Wolfgang Rabitsch and Jean-Claude Streito}

Description and biological cycle: Small tingid true bug, adults whitish with lacelike forewings, nymphs black with spines, average adult body size $3.5 \mathrm{~mm}$. Adults hibernate under loose bark of their host trees. Females lay up to 350 eggs. Development from egg to adult takes $45 \mathrm{~d}$, 1-3 generations per year. Sycamore lace bug feeds on different Platanus species (Platanaceae). In the introduced range, it is regularly found on P. occidentalis and P. orientalis and their hybrid $P$. acerifolia, used as an ornamental tree in cities.

Native habitat (EUNIS code): G1 - Broadleaved deciduous woodland.

Habitat occupied in invaded range (EUNIS code): I2 - Cultivated areas of gardens and parks; X22 - Small city centre non-domestic gardens; X24 - Domestic gardens of city and town centres.

Native range: North America, east of the Rocky Mountains.

Introduced range: First record for Europe dates back to 1964, when found in northern Italy (Padua). It is now distributed over much of Europe with records in the west (Portugal), north (United Kingdom) and east (Russia) (Map). Sycamore lace bug was also introduced to China, Korea, Japan, Australia and Chile.

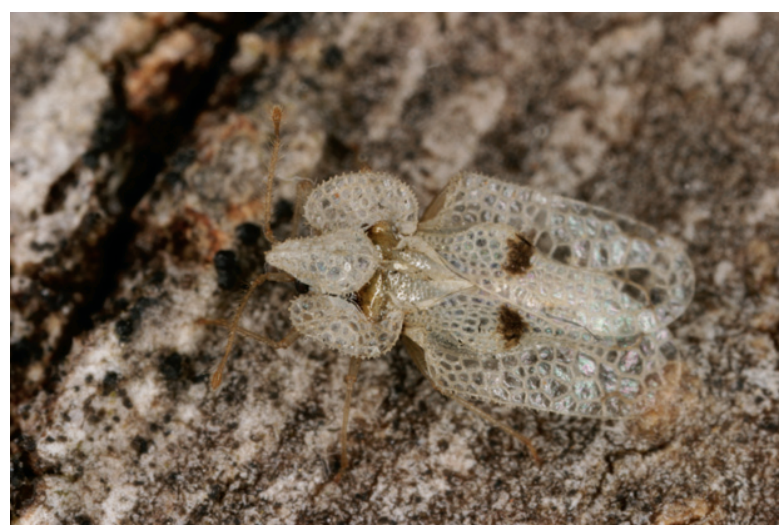

Credit:Wolfgang Rabitsch 


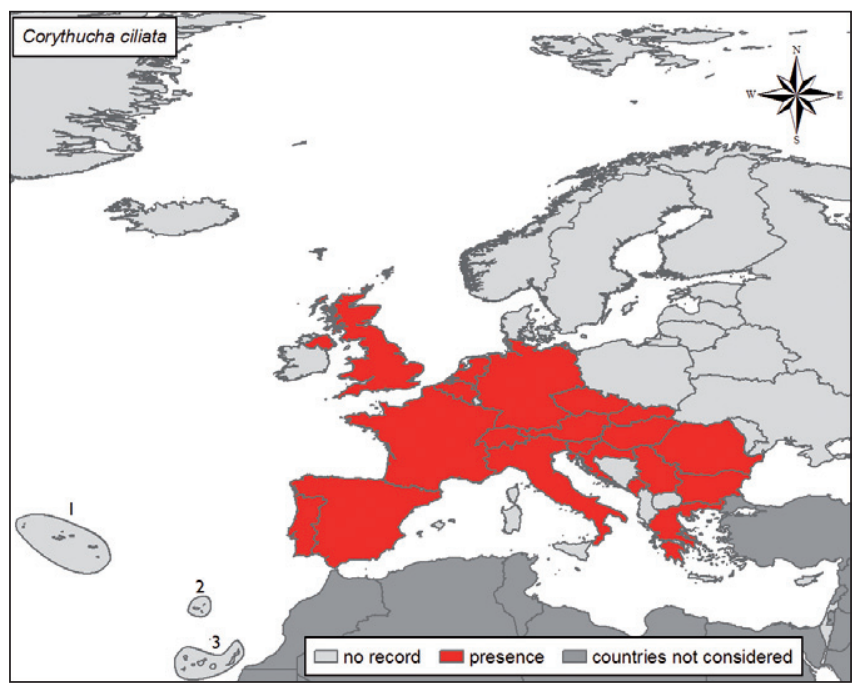

Pathways: Long-distance dispersal occurs with human activity (transport via vehicles or clothes). The species flies well and also drifts passively by wind.

Impact and management: Corythucha ciliata may cause damage to host trees (chlorotic discolouration, desiccation, premature leaf-fall, reduced photosynthetic activity, and prompt secondary infections by fungi and pathogens). In addition, the species may become a nuisance to people in parks and gardens, but usually impacts are of aesthetic value only. Chemical treatment with insecticides is not recommended.

\section{Selected references}

Arzone A (1986) Spreading and importance of Corythucha ciliata (Say) in Italy twenty years later. Bulletin WPRS, Section Régionale Ouest Paléarctique 9: 5-10.

Servadei A (1966) Un Tingide nearctico comparso in Italia (Corythucha ciliata Say). Bollettino della Societa Entomologica Italiana 96: 94-96.

Stehlík JL (1997) Corythucha ciliata (Say), a pest of plane trees, now also in the Czech Republic (Tingidae, Het.). Acta Musei Moraviae, Scientiae Naturales 81: 299-306. 


\title{
14.53 - Cales noacki Howard, 1907 (Hymenoptera, Aphelinidae)
}

\author{
Jean-Yves Rasplus
}

Description and biological cycle: Traditionally, the genus Cales has been placed in the family Aphelinidae but this position has changed several times. Indeed, within aphelinids, the genus exhibits four-segmented tarsi, straight fore tibial spur, narrow forewing, flagellum with three funicular segments, and unsegmented clava*. Furthermore, the genus does not group with other Aphelinidae in a molecular phylogeny of chalcid wasps. Cales is the only genus of the subfamily Calesinae and comprises three described species that are parasitic on whiteflies, including Cales noacki, an endoparasitoid of woolly whitefly, Aleurothrixus floccosus (Maskell), a serious pest of citrus trees worldwide. $C$. noacki has a preference for second stage nymphs of this whitefly (Photo- C. noacki laying eggs on A. floccosus). However, C. noacki is not species specific and can develop on several species of whiteflies. At $26^{\circ} \mathrm{C}$, the biological cycle of $C$. noacki takes about 21-22 days to be completed. $C$. noacki has always been regarded as a single species, however recent molecular analyses suggest that at least three distinct haplotypes coexist in the biocontrol citrus grove at Riverside. These species have different biology and environmental preferences.

Native habitat (EUNIS code): G1-Broadleaved deciduous woodlands; I- Regularly or recently cultivated agricultural, horticultural and domestic habitats.

Habitat occupied in invaded range (EUNIS code): I- Regularly or recently cultivated agricultural, horticultural and domestic habitats

Native range: South America.

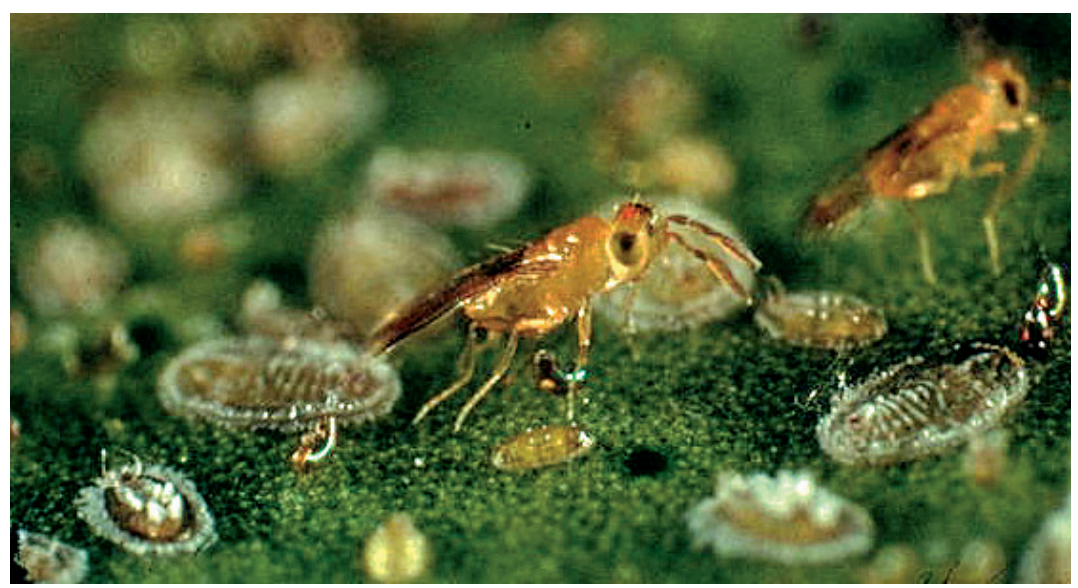

Credit: Jean-Pierre Onillon / INRA Antibes 


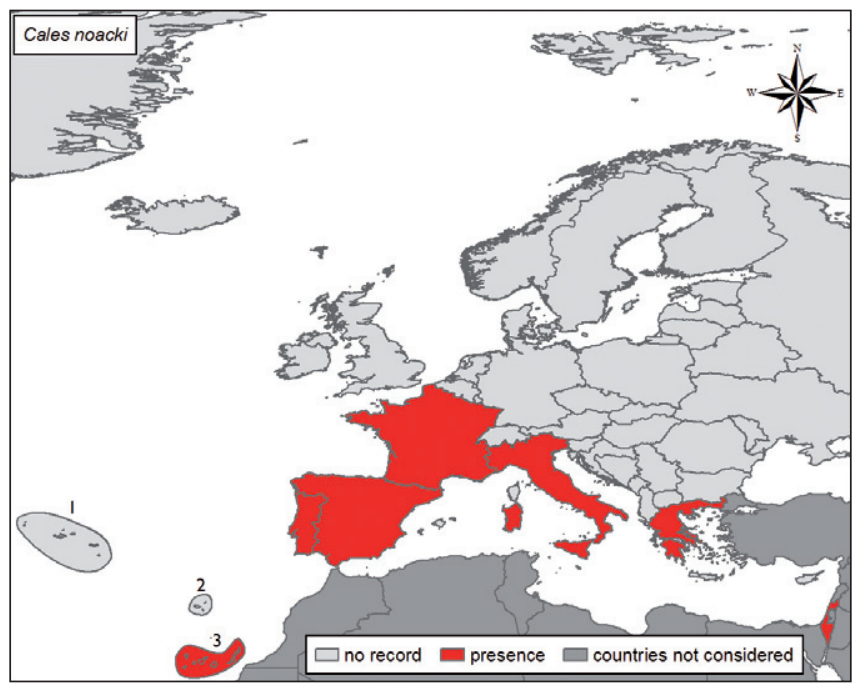

Introduced range: Cales noacki strains released in Europe came from Chile, where they were sampled through biological control projects in the 1970s. The species was thus introduced in France (1971), Spain (1973), Portugal (1977), Italy (1980) and Greece (1991) for inoculative biological control of the woolly whitefly, Aleurothrixus floccosus (Map).

Pathways: Intentionnal introduction for biological control.

Impact and management: $C$. noacki is now established in Europe and has proved very effective against the woolly whitefly. The parasitoid has rapidly achieved high rates of parasitization (>90\%) resulting in substantial mortality to populations of the invading whitefly. In some parts of the Mediterranean area, the introduction of Cales noacki as a classical biological control agent against the woolly whitefly, may have led to the partial or complete displacement of native parasitoids of the non-target whitefly species Aleurotuba jelinekii.

\section{Selected references}

Onillon JC (1973) Possibilités de régulation des populations d'Aleurothrixus floccosus Mask.

(Homopt. Aleurodidae) sur agrumes par Cales noacki How. (Hymenopt. Aphelinidae).

Bulletin de l'Organisation Européenne et Méditerranéenne pour la Protection des Plantes 3: 17-26.

Viggiani G (1994) Recent cases of interspecific competition between parasitoids of the family Aphelinidae (Hymenoptera: Chalcidoidea). Norwegian Journal of Agricultural Sciences Supplement 16: 353-359.

Spicciarelli R, Tranfaglia A, Battaglia D, Torraco R (1996) Biological control of Aleurothrixus floccosus with Cales noacki. Informatore Agrario 52: 67-70. 


\title{
14.54 - Lysiphlebus testaceipes (Cresson, 1880) \\ (Hymenoptera, Braconidae)
}

\author{
Jean-Yves Rasplus
}

Description and biological cycle: Small $(<3 \mathrm{~mm})$ dark greenish to black braconid wasp. Female lays an egg on an aphid (Photo-female laying eggs on rose aphid, Macrosiphum rosae $(L)$.$) the endoparasitoid larva grows and transforms it into a dead brown mummy. Develop-$ ment takes about $14 \mathrm{~d}$; the wasp exits from a hole cut in the top of the mummy. Lysiphlebus testaceipes has a 2 days adult lifespan. Females produce 1.8 offspring per aphid patch, spending relatively shorter time on larger groups, while distributing a total of ca. 200 eggs across many patches (Tentelier et al., 2009). L. testaceipes is a generalist parasitoid, exhibiting extremely broad host range (> 200 aphid species on various plants that host notable aphid pests such Aphis, Brachycaudus, Myzus). In natural habitats, Aphidiinae are the main components of parasitoid communities controling aphid populations. Several species have been used for biological control in greenhouses.

Native habitat (EUNIS code): E- Grassland and tall forb habitats; I- Regularly or recently cultivated agricultural, horticultural and domestic habitats.

Habitat occupied in invaded range (EUNIS code): I- Regularly or recently cultivated agricultural, horticultural and domestic habitats.

Native range : Possibly Cuba.

Introduced range: Introduced into Europe (France) from Cuba in the 1970s to control Aphis spiraecola Patch, a pest of Citrus (Stary et al., 1988). This braconid soon became

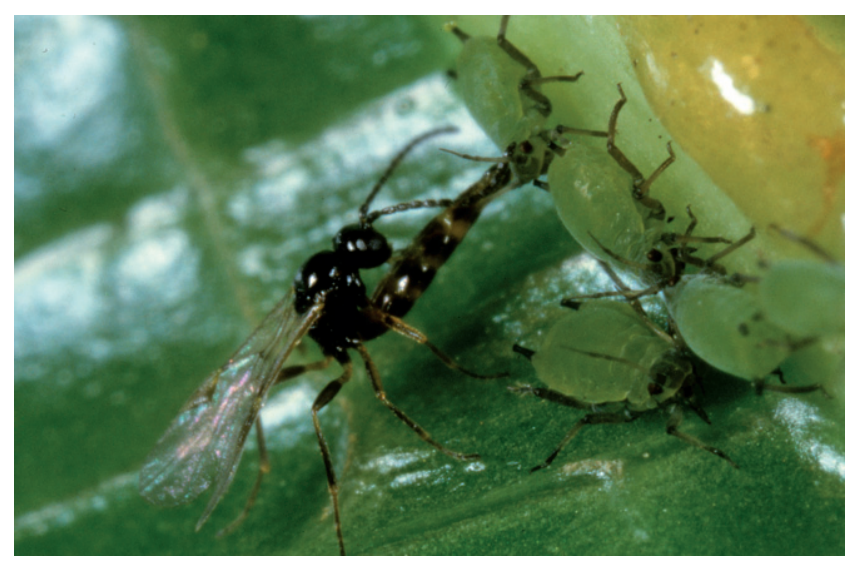

Credit: Peter J. Bryant 


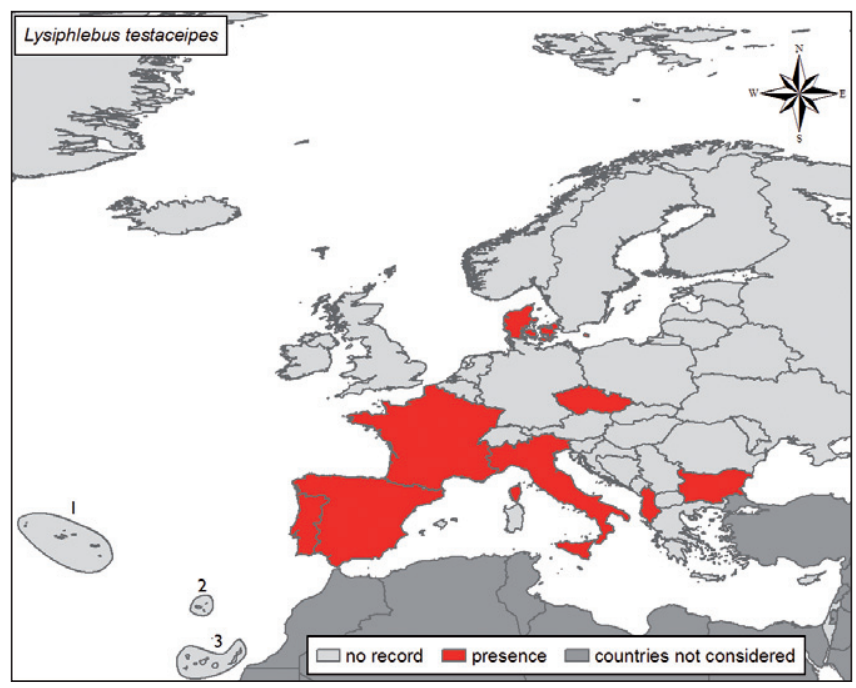

established and subsequently spread in the Mediterranean basin, shifting to other native aphid species, and reaching Italy in 1977, Spain (1982-1984), Portugal (1985) and Greece (2002) (Map).

Pathways: Intentionnal introduction for biological control

Impact and management: In Europe, L. testaceipes is mass-reared, sold and released to control Aphis gossypii Clover. This braconid is a very efficient parasitoid that can reduce host infestations. However, recent studies have clearly shown that L. testaceipes outcompetes indigenous Aphidiinae. For example, on T. aurantii, it may have displaced two congeneric parasitoid species, L. fabarum (Marshall) and L. confuses Tremblay \& Eady (Tremblay 1984). Such collateral effects on local faunas need more studies to estimate better the impact of this species on the parasitoid community foodweb associated with aphids.

\section{Selected references}

Stary P, Lyon JP, Leclant F (1988) Biocontrol of aphids by the introduced Lysiphlebus testaceipes

(Cress.) (Hym., Aphidiidae) in Mediterranean France. Journal of Applied Entomology 105: 74-87.

Tremblay E (1984) The parasitoid complex (Hymenoptera: Ichneumonoidea) of Toxoptera aurantii (Homoptera: Aphidoidea) in the Mediterranean area. Entomophaga 29: 203-209.

Tentelier C, Lacroix MN, Fauvergue X (2009) Inflexible wasps: the aphid parasitoid Lysiphlebus testaceipes does not track multiple changes in habitat profitability. Animal Behaviour 77: 95-100. 


\title{
14.55 - Dryocosmus kuriphilus (Yasumatsu, 1951) - Chestnut gall wasp (Hymenoptera, Cynipidae)
}

\author{
Milka M. Glavendekić and Alain Roques
}

Description and biological cycle: Female black, 2.5-3 mm long (Photo- left). Legs, antennal scapus and pedicel, apex of clypeus and mandibles yellow brown. Antennae 14-segmented with apical segments not expanded into a club. Head finely sculptured. Scutum, mesopleuron and gaster highly polished, smooth. Propodeum* with three distinct longitudinal carinae $^{*}$; propodeum and pronotum strongly sculptured. Scutum* with two notaulices* converging posteriorly. Radial cell of forewing "open”. Eggs oval, milky white, 0.1-0.2 mm long, long-stalked. Full-grown larva $2.5 \mathrm{~mm}$ long, milky white, without eyes and legs. Pupa $2.5 \mathrm{~mm}$ long, dark brown. Monophagous on Castanea spp. and their hybrids, attacking Castanea crenata Sieb. et Zucc. (Japanese chestnut), C. dentata (Marsh.) (American chestnut), C. mollissima Blume (Chinese chestnut), C. sativa Mill. (European chestnut) and C. seguinii Dode (in China). Univoltine and thelytokous* parthenogenetic species. Adults emerge from galls from end of May until end of July. Lifetime short (about $10 \mathrm{~d}$ ). Females lay 3-5 eggs per cluster inside buds. Each female can lay > 100 eggs. Some buds contain 20-30 eggs. Embryonic development lasts 30-40 d. Early instar larvae overwinter inside chestnut buds. At the time of bud burst in spring, gall wasps induce formation of a 5-20 mm diameter green (Photo right) or rose-coloured gall, containing 1-7 or 8 small cells where early instars develop. Galls develop in mid April on new shoots, leaves and twigs. Larvae feed 20-30 d within the galls before pupation from mid-May to mid-July.

Native habitat: (EUNIS code): G- Woodland and forest habitats and other wooded land.

Habitat occupied in invaded range: G1 - Broadleaved deciduous woodland; G5 - Lines of trees, small anthropogenic woodlands, recently felled woodland, early-stage woodland and coppice. Chestnut forests and monocultures within coppice deciduous forests, chestnut orchards, lines of chestnut trees, gardens, ornamental cultures.

Native range: Asia (China).

Introduced range: In Europe, first recorded in 2002 near Cuneo, Italy, then from Slovenia (2006), France (Alpes- Maritimes, 2007) Switzerland (2009), Hungary (2009) and elsewhere in Italy (Map). Also introduced in Japan, Korea, and USA.

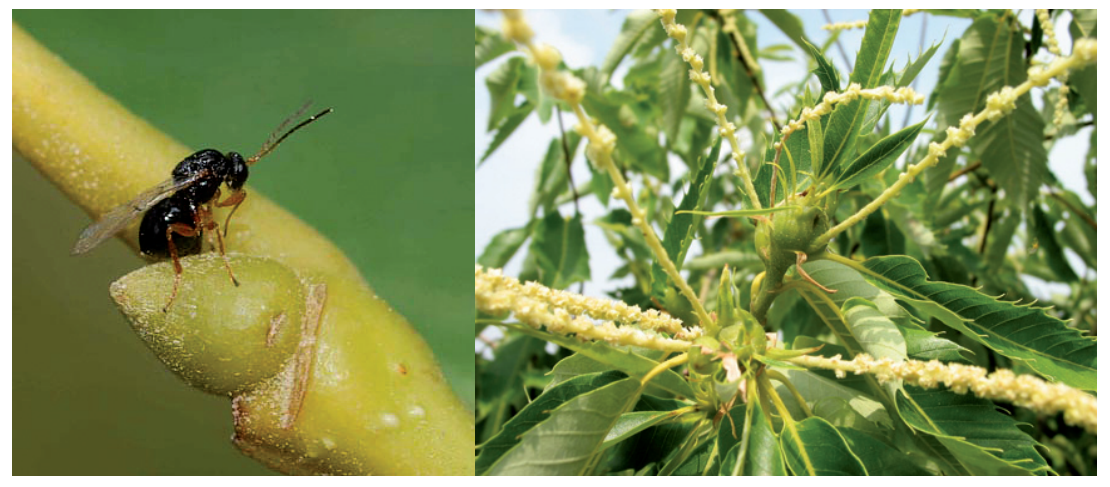




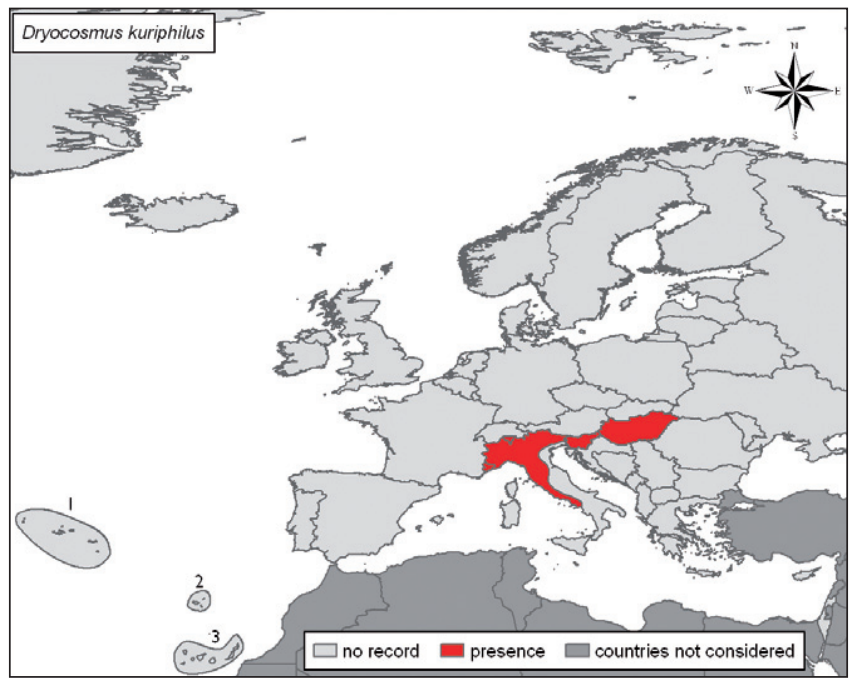

Pathways: Passive transport with plants for planting and cut branches. Dispersal at a local scale is realized by adult flight.

Impact and management: Chestnut gall wasp is the most severe worldwide insect pest on chestnuts. It disrupts twig growth and reduces fruiting, causing yield reduction up to $70 \%$. Severe infestations may result in the decline and death of young chestnut trees and debilitate chestnut forests. Rapid recruitment of generalist parasitoids shared with oak cynipids suggests that chestnut gall wasp may have a negative impact on native cynipids through apparent competition. An effective measure would be to prohibit import of chestnut cut branches (or young plants) for grafting from China, Japan and America. In Italy, France and Slovenia, chestnut nurseries should be inspected annually to ensure trade of safe young plants. Infestations in small chestnut orchards may be reduced by pruning and destroying infested shoots. Treatment with systemic insecticides during the growing season at the place of production can be applied but is insufficient for control; as yet there are no efficient chemicals to control this pest. Torymus sinensis Kamijo was already introduced as a biological control agent in Italy from Japan. Several cultivars, prevalently belonging to the species Castanea crenata and its hybrids, are considered resistant; among them, Bouche de Bétizac (C. sativa x C. crenata) was reported. Larvae were found also in this cultivar but they die just at shooting time and do not develop galls. There are also new resistant Japanese and Korean chestnut cultivars.

\section{Selected references}

Csóka G, Wittmann F, Melika G (2009) The oriental sweet chestnut gall wasp (Dryocosmus kuriphilus Yasumatsu, 1951) in Hungary. Novenyvdelem 45: 359-360.

Forster B, Castellazzi T, Colombi L, Furst E, Marazzi C, et al. (2009) First record of the chestnut gall wasp Dryocosmus kuriphilus (Yasumatsu) (Hymenoptera, Cynipidae) in Southern Switzerland. Mitteilungen der Schweizerischen Entomologischen Gesellschaft 82: 271-279.

Graziosi I, Santi F (2008) Chestnut gall wasp (Dryocosmus kuriphilus): spreading in Italy and new records in Bologna province. Bulletin of Insectology 61: 343-348. 


\title{
14.56 - Ophelimus maskelli (Ashmead, 1900) - Eucalyptus gall wasp (Hymenoptera, Eulophidae)
}

\author{
Jean-Yves Rasplus
}

Description and biological cycle: Gall making wasp mostly attacking Eucalyptus species, with a preference for E. camaldulensis and E. tereticornis (= umbellata Smith.), but with a hostplant range encompassing 14 species of Eucalyptus belonging to three sections. Females can lay up to 100 eggs, usually in batches. They oviposit preferentially on the immature leaf blade close to the petiole, in the lower canopy. Each egg induces a small (about $1 \mathrm{~mm}$ diameter) pimple-like gall visible on both side of the leaf; galls are well separated (Photo). Gall density can reach 36 per $\mathrm{cm}^{2}$ in Israel. O. maskelli has three generations per year in Israel and probably also in other Mediterranean countries (Protasov et al 2007).

Native habitat (EUNIS code): G1 Broadleaved deciduous woodland.

Habitat occupied in invaded range (EUNIS code): G1 - Broadleaved deciduous woodland; G5 - Lines of trees, small anthropogenic woodlands, recently felled woodland, early-stage woodland and coppice; I2 - Cultivated areas of gardens and parks; X24 Domestic gardens of city and town centres.

Native range: Australia.

Introduced range: $O$. maskelli, erroneously reported as $O$. eucalypti (Gahan), has been introduced in the Mediterranean area since at least 2000. O. maskelli was first recorded in Italy (2000) (Arzone \& Alma, 2000), then in Greece (2002), Spain (2003), UK (2004), France (2005), Portugal (2006) (Map). It also occurs in Israel and Turkey.

Pathways: Trade of ornamental plants.

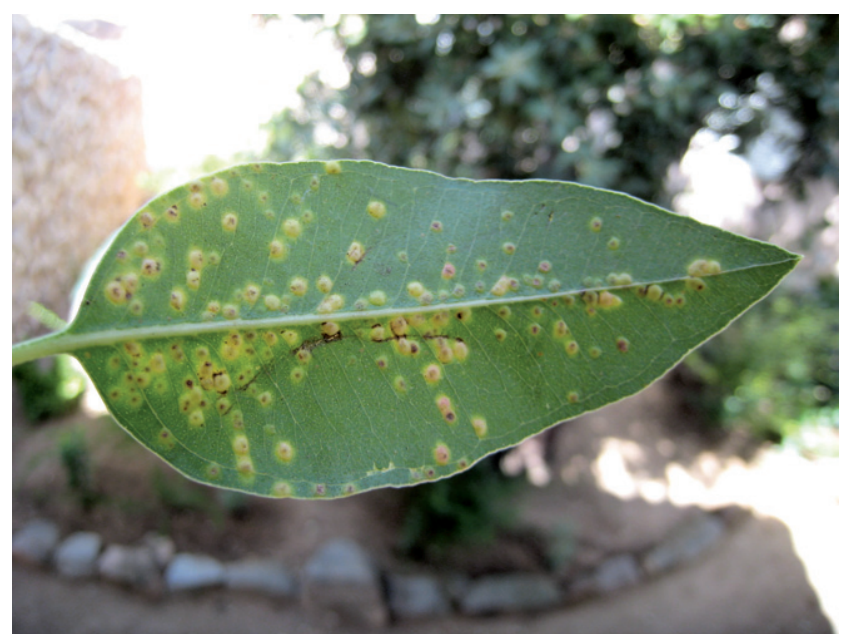

Credit: Alain Roques 


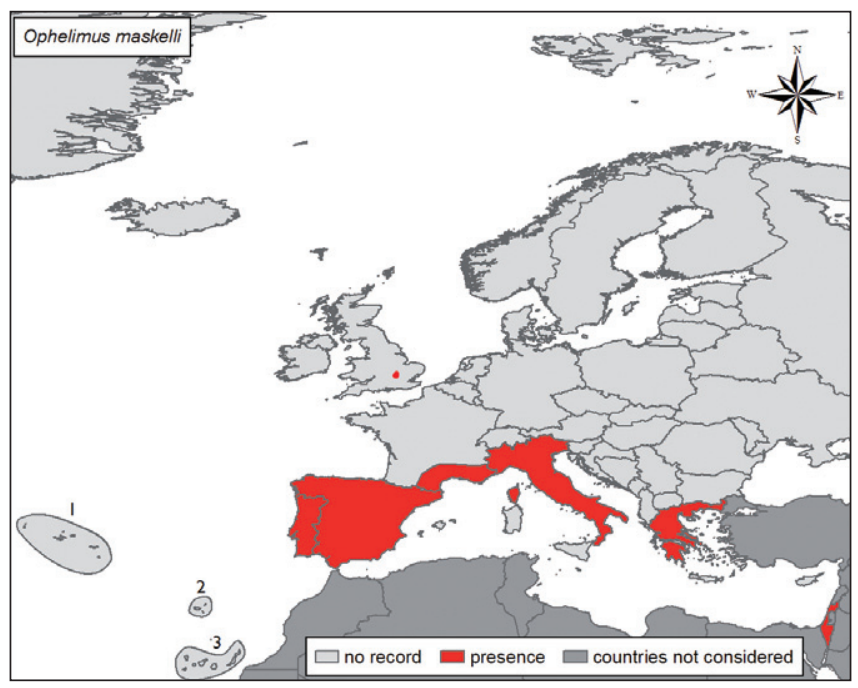

Impact and management: Heavy leaf galling can lead to premature shedding of leaves and dessication of large parts of tree crowns, resulting a depreciated value. Some Eucalyptus are particularly affected, such as E. camaldulensis planted for forestry in the Mediterranean region and the Middle East. Repeated attacks can lead to loss of foliage from terminal branches. Heavy galling can damage two thirds of the entire leaf volume and results in premature shedding of the leaves. The impact of the wasp on E. camaldulensis is consequently serious and heavily infested trees exhibit strong desiccation of their crowns and premature leaf drop. Interestingly, O. maskelli has similar host range to Leptocybe invasa Fisher \& LaSalle, another Eulophid wasp developing on Eucalyptus and introduced in the Mediterranean basin from Australia. Adults emerge en masse in large clouds that cause nuisance and health problems to humans (Protasov et al 2007). Closterocerus chamaeleon (Hymenoptera Eulophidae) has been used to successfully control O. maskelli in Israel and also in Portugal. This wasp exhibits several biological traits that favour population increase and spread, such as thelytoky*, high fecundity, short generation time, and high longevity that favours wind dispersion (Branco et al, 2009).

\section{Selected references}

Arzone A, Alma A (2000) A gall Eulophid of Eucalyptus in Italy. Informatore Fitopatologico 50: 43-46.

Branco M, Boavida C, Durand N, Franco JC, Mendel Z (2009) Presence of the Eucalyptus gall wasp Ophelimus maskelli and its parasitoid Closterocerus chamaeleon in Portugal: First record, geographic distribution and host preference. Phytoparasitica 37: 51-54.

Protasov A, La Salle J, Blumberg D, Brand D, Saphir N et al. (2007) Biology, revised taxonomy and impact on host plants of Ophelimus maskelli, an invasive gall inducer on eucalyptus spp. in the Mediterranean area. Phytoparasitica 35: 50-76. 


\title{
14.57 - Lasius neglectus Van Loon, Boomsma \& Andrásfalvy, 1990 - Garden Ant (Hymenoptera, Formicidae)
}

\author{
Wolfgang Rabitsch
}

Description and biological cycle: Ant with workers lacking erect hairs on the scape and extensor of hind tibiae, and with reduced mandibular dentition (Photo). Female immediately recognizable within European Lasius by its comparatively reduced size and proportionately smaller gaster, as compared with the thorax. Male the smallest of European Lasius. Sister species of Lasius turcicus Santschi. Ants are active throughout the entire day and aphid tending lasts for $24 \mathrm{~h} / \mathrm{d}$, from late April to late October, imposing a non-negligible cost on the energetic budget of individual trees. Nuptial flight seems to be absent. Nests are very difficult to delimit as they may coalesce and integrate a supercolony occupying enormous areas, as large as 16 ha. In urban areas, colonies are fragmented but may occupy a single tree. Finding many dealate* queens (polygyny) in a nest is a key diagnostic of this species, the single polygynous European Lasius (s.str.). The number of queens depends on colony size, but estimated from queens found under stones, was about 35,500 in the Seva supercolony. Using soil cores, worker number for that population in May 2002 was estimated as $1.12 \times 10^{8}$. This species is truly unicolonial., with inter-nest and inter-population relationships showing a typical unicolonial trait of reduced level of aggressiveness. Areas occupied furnish a wide array of possible nesting sites: under stones, temporal refuges with aphids at the base of herbs, amid rubbish, etc. The expansion process of a colony seems to be much helped by the progressive urbanization of lots. This development usually implies the cutting and burning of all natural vegetation but trees. The planting of grass and continuous irrigation that follows favours ant establishment.

Native habitat (EUNIS code): Unknown.

Habitat occupied in invaded range (EUNIS code): I2 - Cultivated areas of gardens and park; X24- Domestic gardens of city and town centres. Populations live in a wide range of conditions, from strictly urban habitats, streets with heavy traffic to semi-urban sites, mildly

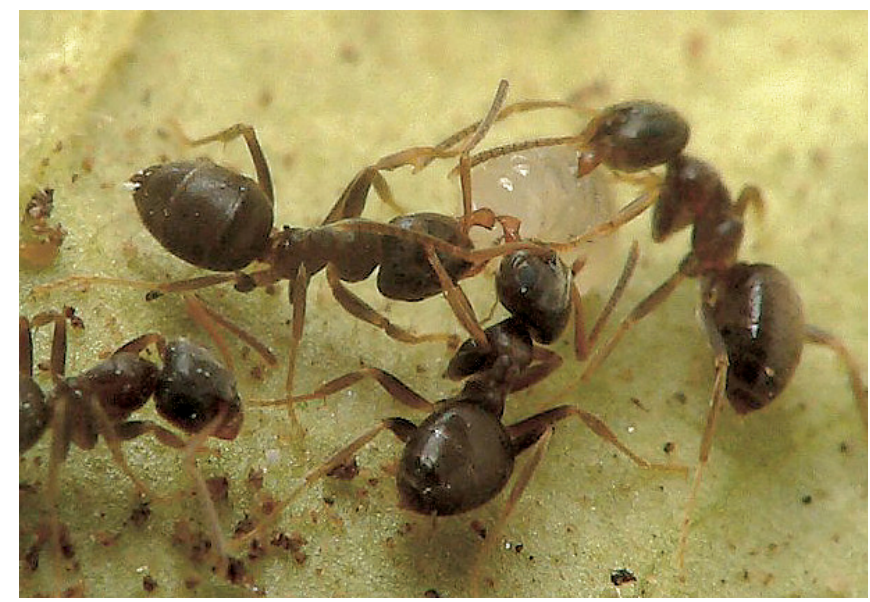

Credit: Jordan Wagenknecht, antbase.fr 


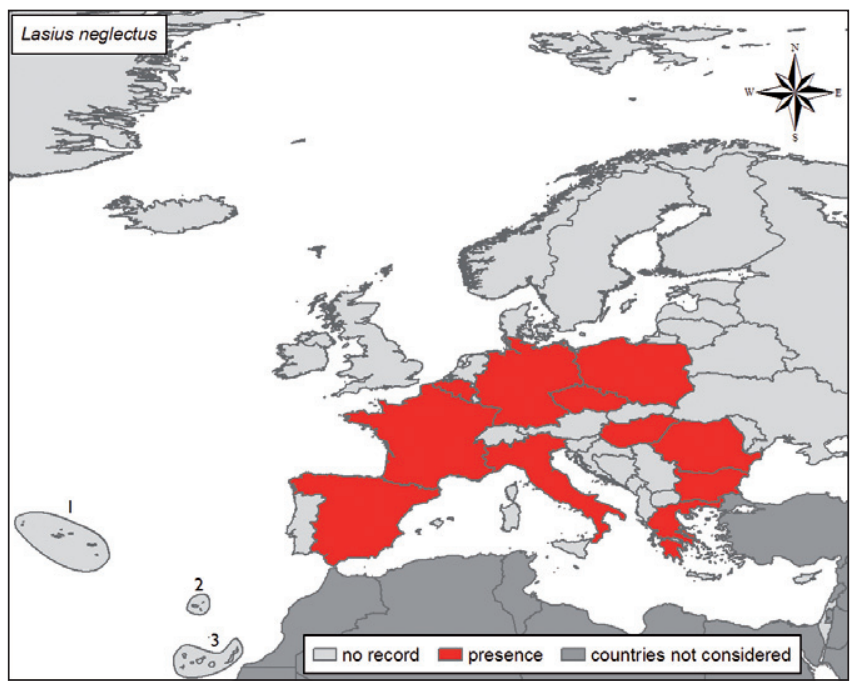

degraded habitats or seemingly undisturbed localities. A common feature to all such places is the presence of trees, on whose aphid populations the ants depend.

Native range: Asia (possibly Turkey).

Introduced range: The species was described in 1990 (Van Loon et al. 1990), although its presence in the garden of the Company for the Development of Fruit and Ornamental Production at Budapest, Hungary, was already known from the early seventies (Andrásfalvy, in litt.). Colonies were later observed in Western, Central and Southeastern Europe (Map).

Pathways: Present distribution is likely to have been mediated by human intervention (commerce and transport of goods, soil, potted plants). Given the seeming absence of nuptial flight, dispersal capacity of this ant is very low. Local expansion is a very slow process and distances attained are two to five orders of magnitude smaller than minimum distances between known populations.

Impact and management: In areas occupied by this species, other surface-foraging ant species have vanished or have reduced populations. Other arthropod groups also seem to be affected in positive (increased abundance; aphids), negative (lower density; lepidoptera larvae) or neutral ways. Occupation of electrical conduits in homes may cause nuisance to people.

\section{Selected references}

Cremer S, Ugelvig LV, Drijfhout FP, Schlick-Steiner BC, Steiner FM et al. (2008) The Evolution of Invasiveness in Garden Ants. PLoS One 3 (12): e3838. doi-10.1371/journal. pone. 0003838

Espadaler X, Tartally A, Schulz R, Seifert B, Nagy C (2007) Regional trends and local expansion rate in the garden invasive ant Lasius neglectus (Hymenoptera, Formicidae). Insectes sociaux 54: 293-301.

Van Loon AJ, Boomsma JJ, Andrásfalvy A (1990) A new polygynous Lasius species (Hymenoptera, Formicidae) from Central Europe. I. Description and general biology. Insectes Sociaux 37: 348-362. 


\title{
14.58 - Linepithema bumile (Mayr, 1868) - Argentine ant (Formicidae, Hymenoptera)
}

\author{
Wolfgang Rabitsch
}

Description and biological cycle: Light brown ant; females 4.5-4.9 $\mathrm{mm}$ long and workers 2.1-3.0 mm long (Photo) Omnivorous, feeding on honeydew, nectar, insects and carrion. Local dispersal by budding of large unicolonial nests (up to $150 \mathrm{~m} /$ year); long-distance dispersal human-mediated within the introduced ranges. Haplodiploid system with sterile workers; polygynous (multi-queened) nests; social organisation variable in its native range (from multicolonial to unicolonial), but entirely unicolonial in introduced range, with surface area covered by single supercolonies ranging from $2500 \mathrm{~m}^{2}$ to many $\mathrm{km}^{2}$. In the absence of queens, workers can lay unfertilised eggs, which develop into fully functional males. Prefers moderate temperature and moisture levels.

Native habitat (EUNIS code): G- tropical and subtropical natural forests.

Habitat occupied in invaded range (EUNIS code): I- Regularly or recently cultivated agricultural, horticultural and domestic habitats; G4- Mixed deciduous and coniferous woodland; preferably associated with disturbed, human-modified habitats in its introduced range, but may also invade natural habitats (e.g., oak and pine woodland in the Mediterranean basin).

Native range: South America.

Introduced range: The Argentine ant occurs throughout the world on all continents, especially in mediterranean-type climates, and many oceanic islands. First recorded in Europe in 1847 in Portugal, it invaded most of the Western Mediterranean Europe and Central Europe (Map). Ecological niche models predict that with changing climate, the species will expand at higher latitudes.

Pathways: Transported with vehicles (airplanes, ships) together with goods and materials, soil, plants, etc.

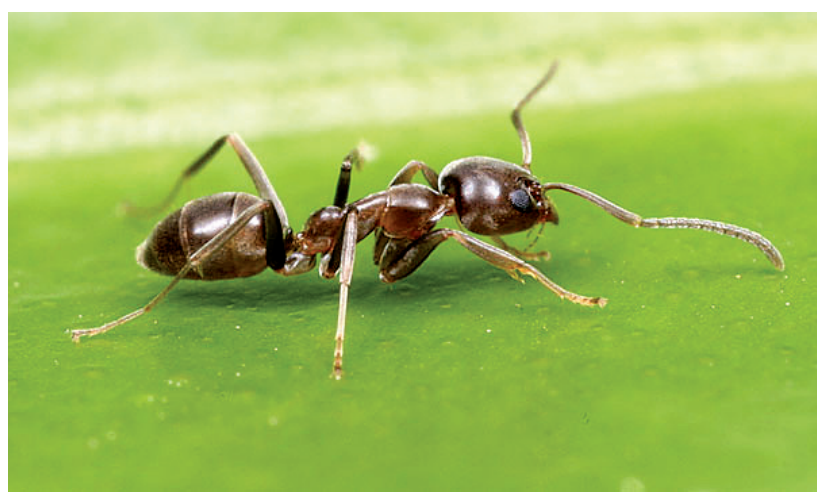

Credit: Alex Wild 


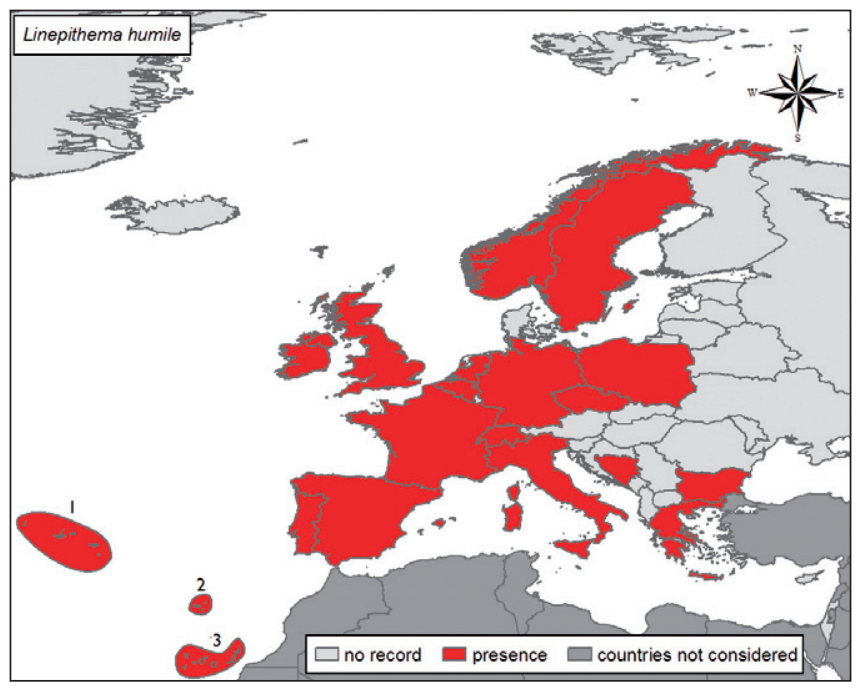

Impact and management: Supercolonies, by reducing costs associated with territoriality, allow high worker densities and interspecific dominance in invaded habitats. It has displaced native ant species in many parts of the world, even leading to species extinction in some cases. Also competes with other arthropod species for resources (e.g., for nectar with bees) and reduces local arthropod diversity. Taxa other than arthropods are also affected (e.g., causes nest failure of birds). Ecosystem level impacts such as reduction of seed dispersal capacity and disruption of mutualistic associations with other species are documented. Regarded as a nuisance for tourism at some places on the Mediterranean coast. Tending behaviour may increase homopteran populations, causing some crop loss. However, these costs are considered to be low. Several chemicals have been applied via ant baits, including insect growth regulators. Application needs supervision to optimise results and to minimise side-effects on non-target species. Since Argentine ants prefer disturbed sites, any extensification of land use or reduction in monoculture may help prevent high densities.

\section{Selected references}

Carpintero S, Reyes-López J, Arias de Reyna L (2005) Impact of Argentine Ants (Linepithema humile) on an arboreal ant community in Donana National Park, Spain. Biodiversity and Conservation 14: 151-163

Giraud T, Pedersen JS, Keller J (2002) Evolution of supercolonies: The Argentine ants of southern Europe. Proceedings of the National Academy of Sciences 99: 6075-6079

Way MJ, Cammell ME, Paiva MR, Colligwood CA (1997) Distribution and dynamics of the argentine ant Linepithema (Irydomirmex) humile (Mayr) in relation to vegetation, soil conditions, topography and native competitor ants in Portugal. Insectes Sociaux 44: 415-433. 


\title{
14.59 - Nematus tibialis Newman, 1837 - Locust sawfly, false acacia sawfly (Hymenoptera, Tenthredinidae)
}

\author{
Milka Glavendekić
}

Description and biological cycle: Adult 6-7 mm long, head marked yellow above, thorax and abdomen marked with black; antennae black. Scutellum yellow. Legs yellow, exception of hind tibiae and tarsi, which are black and distinguish Nematus tibialis from the other sawflies. Larva green and shiny, $12 \mathrm{~mm}$ long with brownish-green head marked with black (Photo right). Feeds exclusively on black locust, Robinia pseudoacacia L., and its various ornamental cultivars, and on bristly locust Robinia hispida L. Adults emerge in May and June. Females deposit eggs in young leaflets and of the host plant. The young larvae feed on leaves, forming a small hole through the lamina (Photo left). Later, larvae consume more leaf area until maturity. Larval development last two to three weeks after which they enter the soil, forming tough dark brown cocoons, where they pupate. Adults emerge shortly afterwards. False Acacia sawfly develops a second generation in the late summer and sometimes a third brood in the autumn.

Native habitat (EUNIS code): G1- Broadleaved deciduous woodland; G4- Mixed deciduous and coniferous woodland; G5- Lines of trees, small anthropogenic woodlands, recently felled woodland, early-stage woodland and coppice.

Habitat occupied in invaded range (EUNIS code): G1- Broadleaved deciduous woodland; G5- Lines of trees and, small anthropogenic woodlands: plantations of black locust aimed to stop erosion, recently felled woodland, early-stage woodland and coppice, in the green belt down highways and at all sites where black locust is growing like a weed; I2 - Cultivated areas of gardens and parks; X6- Crops shaded by trees on sites where wind erosion is managed by planting black locust.

Native range: North America (Pennsylvania).

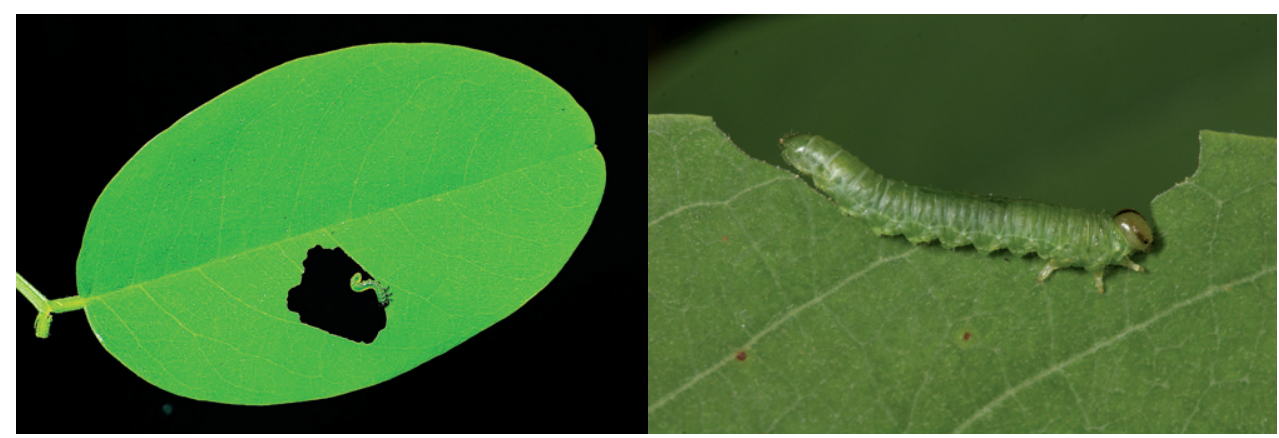

Credit: György Csóka 


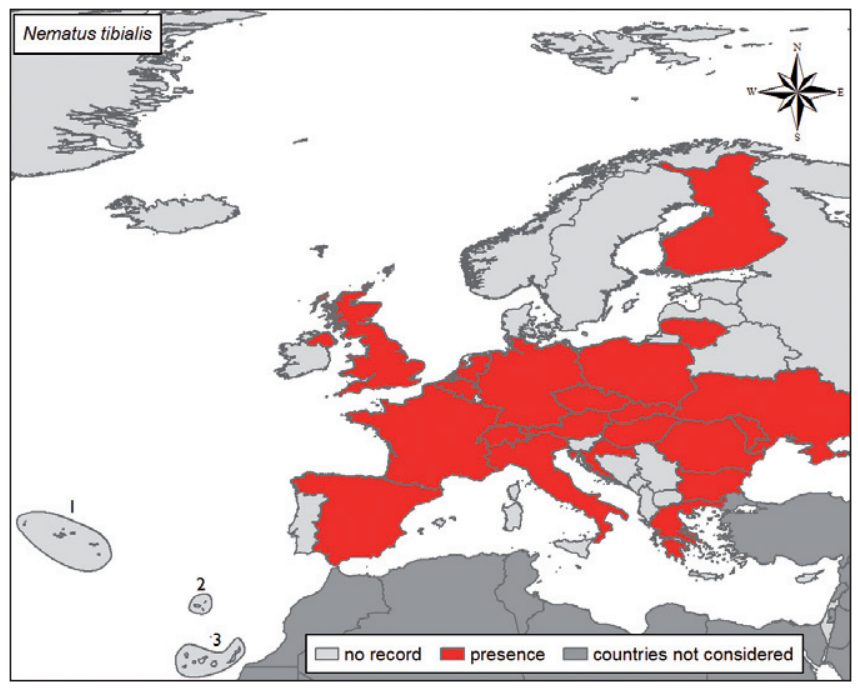

Introduced range: First detected in Europe in 1825 in Germany. Then established in most countries of Western, Central and Southern Europe (Map).

Pathways: Plant trade for ornamental purposes (parks, gardening, bonsai).

Impact and management: Severe defoliation of leaves is common on black locust and bristly locust. Holed or partially devoured leaves on ornamental trees and nursery stock reduce ornamental value and health condition of young plants. Nematus also shares a leaf eating niche with several other invasive species, Parectopa robiniella, Phyllonorycter robiniella, Obolodiplosis robiniella, as well as with various aphids and mite species. Control measures are not needed in most cases. The survey of natural enemies revealed egg and larval parasitoids potentially available for biological control. The egg parasitoid Trichogramma aurosum Sugonjaev and Sorokina 1975 (Trichogrammatidae) is recorded from different locations in Central and Western Europe (Denmark, Netherlands, Austria, Luxemburg, Belgium and Germany). Impact is known on local fauna. A larval parasitoid Lathiponus bicolor (Brischke) (Ichneumonidae) has newly adapted to $N$. tibialis after switching from the congeneric native sawfly species, Nematus salicis L.and N. yokohamensis auct.

\section{Selected references}

Ermolenko VM, Sem'yanov VP (1981) Development of the fauna of sawflies (Hymenoptera, Symphyta) of man-made coenoses of cultivated lands in the south of the European part of the USSR. Noveishie dostizheniya sel'skokhozyaistvennoi entomologii (po materialam USh sëzda VEO, Vilnius, 9-13 October 1979.): 73-76.

Markovic C, Stojanovic A (2008) Finding of locust sawfly Nematus tibialis (Newman) (Hymenoptera, Tenthredinidae) in Serbia. Biljni Lekar 36: 131-135. 


\title{
14.60 - Megastigmus spermotrophus Wachtl, 1893 - The Douglas-fir seed chalcid (Hymenoptera, Torymidae)
}

\author{
Alain Roques
}

Description and biological cycle: Female $2.8-4.3 \mathrm{~mm}$ long, body entirely brownish-yellow to orange- yellow with a few darker spots and an ovipositor as long as body (Photo). Male 2.7-3.8 $\mathrm{mm}$ long, with body colour dark lemon yellow with distinct black patterns on head, thorax, propodeum and first two abdominal segments. Adults emerge from late April to mid-June, depending on location. Oviposition occurs after the host plant cone becomes pendant, when its water content is near its maximum. Egg laying begins when a red-brown or purple margin appears on cone scales and lasts until the cone scale turns entirely red-brown. In seed orchards, the oviposition period may last up to 7 weeks. Most oviposition punctures are made on scale margins, resulting in conspicuous resin droplets. Eggs are laid directly into the seed. The hatching larva feeds on archegonia*, then on cotyledons. The following larval instars progressively consume the megagametophyte* (endosperm), which is entirely destroyed by July. Larvae can successfully develop in unpollinated, unfertilized seeds where they prevent megagametophyte abortion. Larval diapause may extend up to four years, but most individuals emerge during the first two years. The proportion of individuals in prolonged diapause is highly correlated with cone abundance in the year following larval development. Sex ratio is highly variable with location and year, usually ranging from 1:0.5-1:1.5. In North America, Douglas-fir seed chalcid attacks both varieties of Douglas-fir, Pseudotsuga menziesii (var. glauca and var. menziesii). In Europe, it has been found in P. menziesii and on other introduced Pseudotsuga species such as P. macrocarpa and P. japonica.

Native habitat (EUNIS code): G3 - Coniferous woodland.

Habitat occupied in invaded range (EUNIS code): G3 - Coniferous woodland; G4 Mixed deciduous and coniferous woodland ; G5 - Lines of trees, small anthropogenic woodlands, recently felled woodland, early-stage woodland and coppice ; I2 - Cultivated areas of gardens and parks; X11- Large parks; X15- Land sparsely wooded with coniferous trees ; X24Domestic gardens of city and town centres.

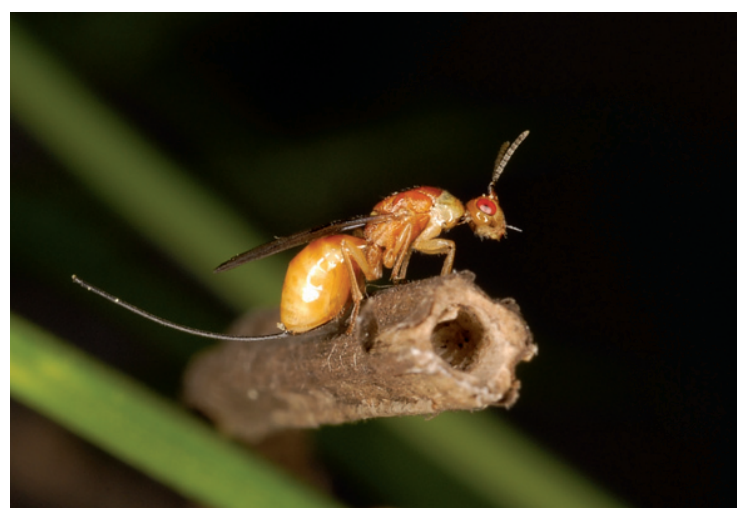




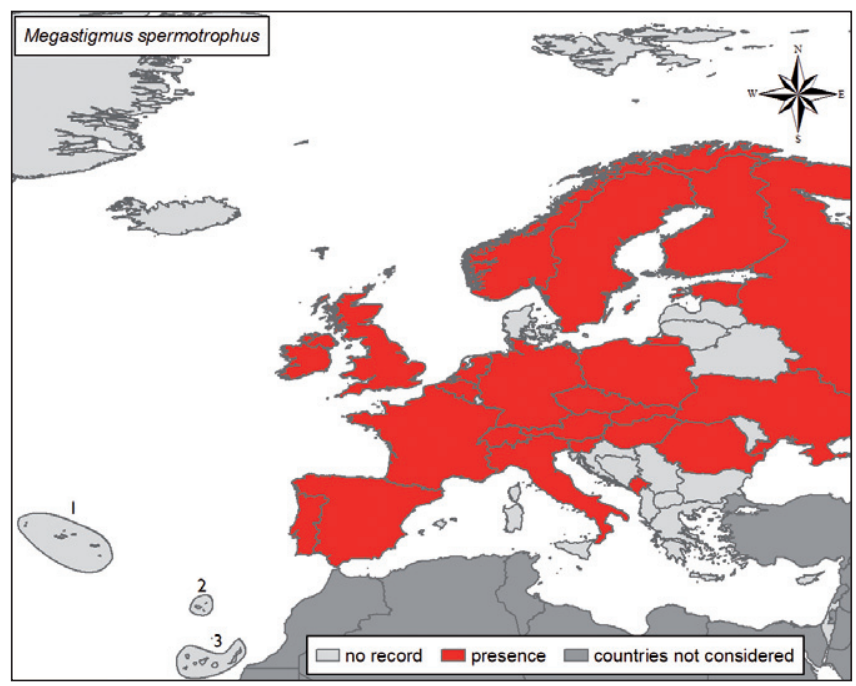

Native range: Western North America, from British Columbia to California and Mexico.

Introduced range: First recorded in Europe in Austria in 1893. Then, observed wherever Douglas-fir has been planted, even in Mediterranean countries (Map).

Pathways: Trade of tree seeds. The presence of larvae is is usually overlooked in traded seed lots, the infested seeds showing up only when X-rayed (see Figure 12.10 in Chapter 12).

Impact and management: In Europe, this species has few indigenous competitors and parasitoids. Thus, the proportion of seeds infested in European seed orchards can reach up to $95 \%$, especially during years of light cone crops. During years of moderate to heavy cone crops, seed infestation varies between 10\%-50\%. However, the true impact of this insect on seed production is difficult to assess because larvae can complete development in unfertilized seeds. For example, in the absence of fertilization, no viable offspring would be produced from seed, but seed damage would be estimated at $100 \%$, because only chalcid-infested seeds can be found. Monitoring can be carried out using yellow traps baited with terpinolete. Chemical control is possible, but effective only against adults, whereas systemic insecticides give contrasting results for larvae concealed in the seeds. The introduction of parasitoids from the native range, e.g. the pteromalids Mesopolobus spp., may constitute an alternative, biological control.

\section{Selected references}

Aderkas P Von, Rouault G, Wagner R, Rohr R, Roques A (2005) Seed parasitism redirects ovule development in Douglas-fir. Proceedings of the Royal Society of London B, 272: 1491-1496.

Mailleux AC, Roques A, Molenberg JM, Grégoire JC (2008) A North American invasive seed pest, Megastigmus spermotrophus (Wachtl) (Hymenoptera: Torymidae): Its populations and parasitoids in a European introduction zone. Biological Control 44: 137-141.

Roques A., Skrzypczynska M (2003) Seed-infesting chalcids of the genus Megastigmus Dalman

(Hymenoptera: Torymidae) native and introduced to Europe: taxonomy, host specificity and distribution. Journal of Natural History 37: 127-238. 


\subsection{1 - Sceliphron curvatum (Smith, 1870), S. caementarium (Drury, 1773) \\ and $S$. deforme (Smith, 1856) \\ (Hymenoptera, Sphecidae)}

\section{Jean-Yves Rasplus}

Description and biological cycle: The genus Sceliphron comprises four species native to Europe. These large black or dark brown wasps, banded with yellow, have thin waist and long legs. In summer, females are seen collecting mud to build their nests composed of several cells (Photo-nest of S. curvatum in Austria). The adult wasp preys on spiders that are packed into the cells, the female lay an egg in the cell and the larva develop at the expense of the stored spiders. During the last 100 years, three alien species of Sceliphron, S. caementarium, S. curvatum and $S$. deforme, have been introduced to Europe, which are treated together here.

Native habitat (EUNIS code): C3- Littoral zone of inland surface waterbodies; G- Woodland and forest habitats and other wooded land.

Habitat occupied in invaded range (EUNIS code): C3- Littoral zone of inland surface waterbodies; X25- Domestic gardens of villages and urban peripheries

Native range: $S$. $(S$.) caementarium is originally native to North America, whilst the two other species belong to another subgenus (Hensenia) which is mostly Asiatic and Australasian.

Introduced range: $S$. caementarium has been accidentally introduced several times into Europe during the $19^{\text {th }}$ and $20^{\text {th }}$ centuries. The species was first reported in 1945 from Versailles (but was never reported there again) and in 1949 from southern France. Since the 1970s, it

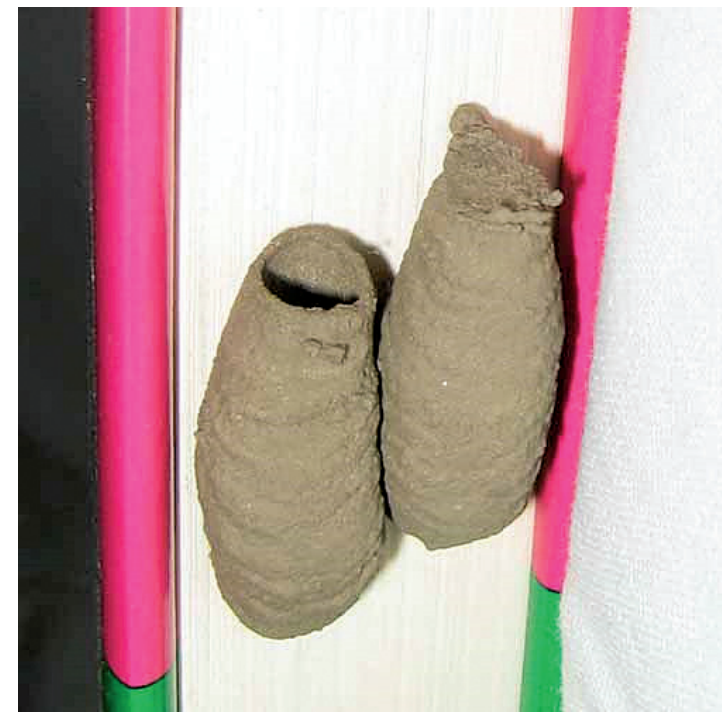

Credit: Christine Sinhuber, www.aculeata.de 


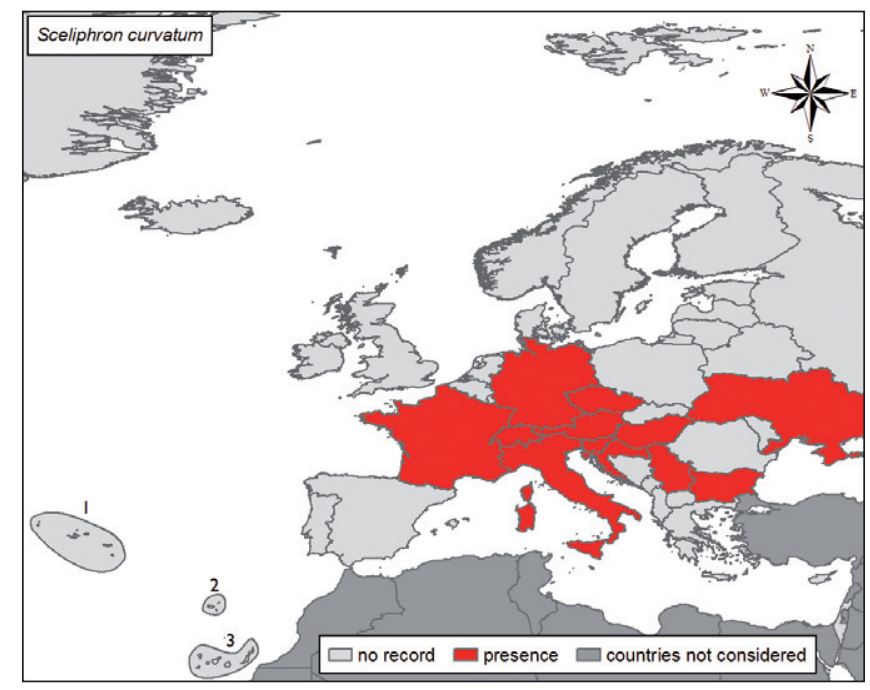

is well established and occurs in several countries (France, Spain, Portugal and Ukraine). S. curvatum was first observed in Austria in the 1970s, where it was probably introduced by human activities. It subsequently spread all over central and southern Europe. The species is now reported from most of southern Europe (France, Italy, Greece), but has also reached northern countries (Netherland, Germany and Czech Republic) (Map). The species probably dispersed on its own following large river valleys, and has reached Mediterranean areas where it finds conditions ecologically similar to its native range. It is mostly associated with urban areas, where it constructs nests in different places of the houses. In southern areas, $S$. deforme may have several overlapping generations. $S$. deforme, a species naturally distributed in central and tropical Asia, is also reported from several east Mediterranean countries: Bulgaria, Greece, Italy and Montenegro.

Pathways: Unknown.

Impact and management: $S$. caementarium and $S$. curvatum probably threaten native Sceliphron species in France and Austria. However, the impact of $S$. curvatum on indigenous Sceliphron species is still poorly understood and needs further study.

\section{Selected references}

Bitsch J, Barbier Y (2006) Répartition de l'espèce invasive Sceliphron curvatum (F. Smith) en Europe et plus particulièrement en France (Hymenoptera, Sphecidae). Bulletin de la Société entomologique de France 111: 227-237.

Cetkovic A, Radovic I, Dorovic L (2004) Further evidence of the Asian mud-daubing wasps in Europe (Hymenoptera: Sphecidae). Entomological Science 7: 225-229.

Gepp J (2003) Verdrängt die eingeschleppte Mauerwespe Sceliphron curvatum autochthone Hymenopteren im Südosten Österreichs? Entomologica Austriaca 8. 


\title{
14.62 - Vespa velutina nigrothorax du Buysson, 1905 - Asian yellow-legged hornet (Hymenoptera, Vespidae)
}

\author{
Claire Villemant, Quentin Rome et Franck Muller
}

Description and biological cycle: Black brown hornet, 20-35 mm long, with gastral segments bordered with a fine orange band, except the $4^{\text {th }}$ that is almost entirely orange; front of head orange, extremity of legs yellow (Photo). This coloration corresponds to the variant nigrithorax du Buysson. While preying on a diverse range of insects, Asian yellow-legged hornet shows a strong preference for honeybees, waiting in flight for workers in front of hives. The large nest, often hooked high in tree tops, may contain several thousand individuals (see Figure 12.11 in Chapter 11). The colony founded in April always dies before the end of the year. Future founder queens only survive and overwinter in bark or ground shelters. Their long-distance dispersal is then possible through agricultural and forestry trade movements. The young queen flight capability is not yet assessed, but in general, a hornet adult is able to fly up to $2 \mathrm{~km}$ from its nest.

Native habitat (EUNIS code): G- Woodland and forest habitats and other wooded land.

Habitat occupied in invaded range: Mostly depends on the presence of high trees or buildings for nesting: X25- Domestic gardens of villages and urban peripheries; X10- Mixed landscapes with a woodland element ("bocages"); G- Woodland and forest habitats and other wooded land.

Native range: Temperate Asia, probably from Yunnan (south-west China).

Invaded range. Introduced in southwestern France (Lot-et-Garonne département) before 2004. Since then, has widely expanded in other parts of France (Map left). The invasion development has been annually traced (Map right).

Pathways: Probably through international horticulture trade.

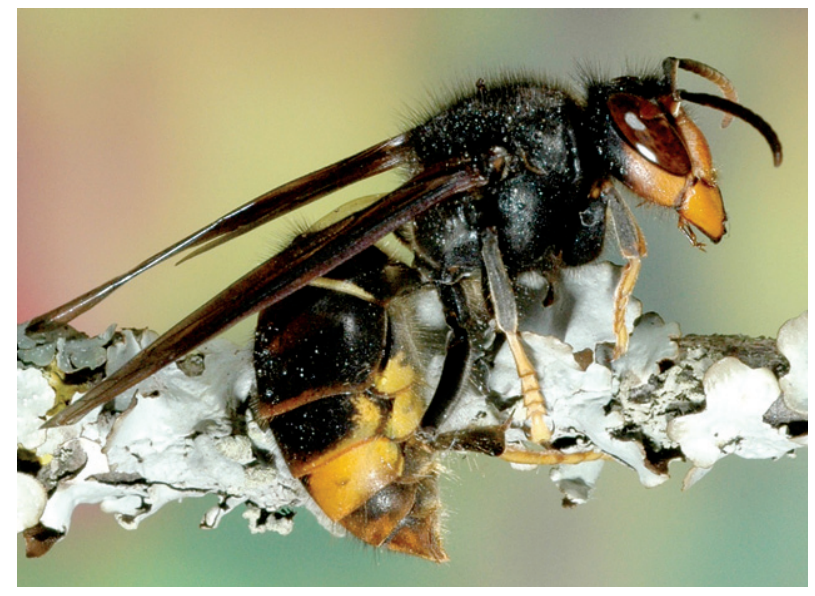

Credit:Jean Haxaire 


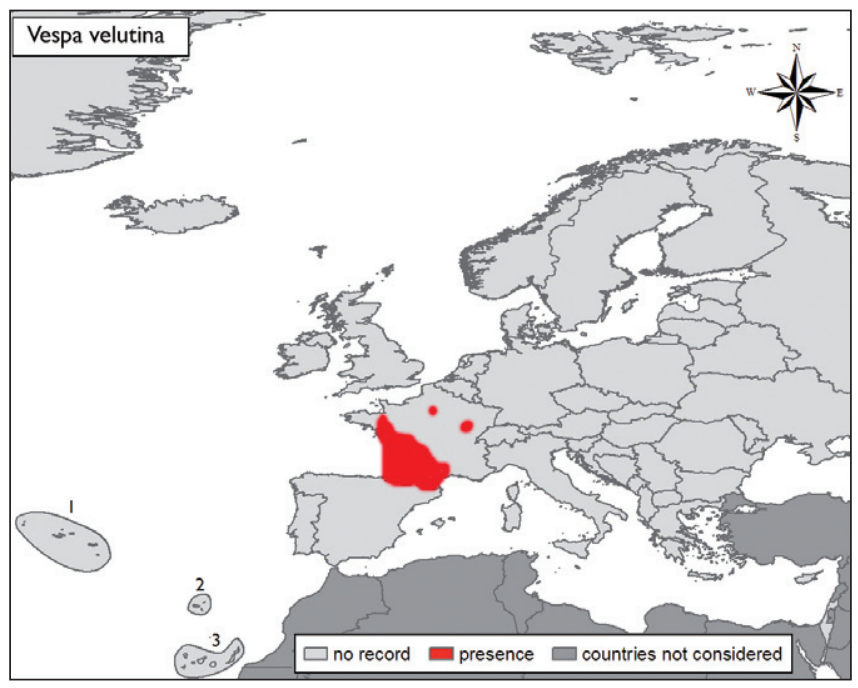

Impact and management: As honeybees are its main prey, the Asian hornet represents a new threat to European beekeeping. It also feeds on ripe fruits, and may thus have detrimental effects on local fruit crops. However, economic impact needs to be accurately assessed. A significant public concern also exists because of the sting risk related to the increasing abundance of nests in invaded urban territories. Ecosystem impact includes threat to biodiversity due to the huge predatory pressure on insects (mainly pollinators), as well as potential side-effects on non target species as a consequence of uncontrolled mass trapping and colony destruction by beekeepers and general public. Traps and poisoned baits kill numerous other insects, notably the common yellow-jackets and the European hornet, while nests filled with insecticides and left on the spot threaten birds that fed intensively on brood of poisoned colonies. Nest distribution in France is mapped each year within the program Inventaire National du Patrimoine Naturel website (MNHN, Paris). Chemical control: mass destruction of founder queens in spring seems to have virtually no effect; the best control measure is to kill off a colony by spraying cypermethrine inside the nest after dark, when foraging activities have ceased. The nest is then removed and burnt. However, nests are often difficult to locate before leaf fall, when sexual progeny is already produced. The use of specific baited mass traps to protect hives is under investigation.

\section{Selected references}

Haxaire J, Bouquet JP, Tamisier JP (2006) Vespa velutina Lepeletier, 1836, une redoutable nouveauté pour la Faune de France (Hym., Vespidae). Bulletin de la Société entomologique de France 111: 194.

Villemant C, Haxaire J, Streito JC (2006) Premier bilan de l'invasion de Vespa velutina Lepeletier en France (Hymenoptera, Vespidae). Bulletin de la Société entomologique de France 111: 535-538. 


\title{
14.63 - Reticulitermes flavipes (Kollar, 1837) - Eastern subterranean termite (Isoptera, Rhinotermitidae)
}

\author{
Marc Kenis
}

Description and biological cycle: The genus Reticulitermes is represented by several species in Europe, America and Asia. A complex of closely related species with uncertain taxonomic status occurs in southern Europe. One species, $R$. flavipes, is of North American origin and has been introduced into Western France, where it had been first described as $R$. santonensis de Feytaud and subsequently synonymised with $R$. flavipes. The same species has also been accidentally introduced in some cities in Germany and Austria. In France, $R$. flavipes is expanding its range further north. In common with all termites, Reticulitermes spp. are social, living in colonies in the soil. These colonies contain various castes: workers, soldiers, alate reproductives and replacement reproductives. The latter are particularly numerous in Reticulitermes spp. and allow the species to build up colonies of millions of individuals. Nests are built in the ground, usually in a humid environment. Workers bore into wood in contact with the ground to feed the colony (Photo). Dry wood (e.g. building structures) as well as living trees or other sources of cellulose can be attacked.

Native habitat (EUNIS code): G1- Broadleaved deciduous woodlands; I- Regularly or recently cultivated agricultural, horticultural and domestic habitats; J- Constructed, industrial and other artificial habitats.

Habitat occupied in invaded range (EUNIS code): G1 Broadleaved deciduous woodlands, I: Regularly or recently cultivated agricultural, horticultural and domestic habitats, J: Constructed, industrial and other artificial habitats.

Native range: North America.

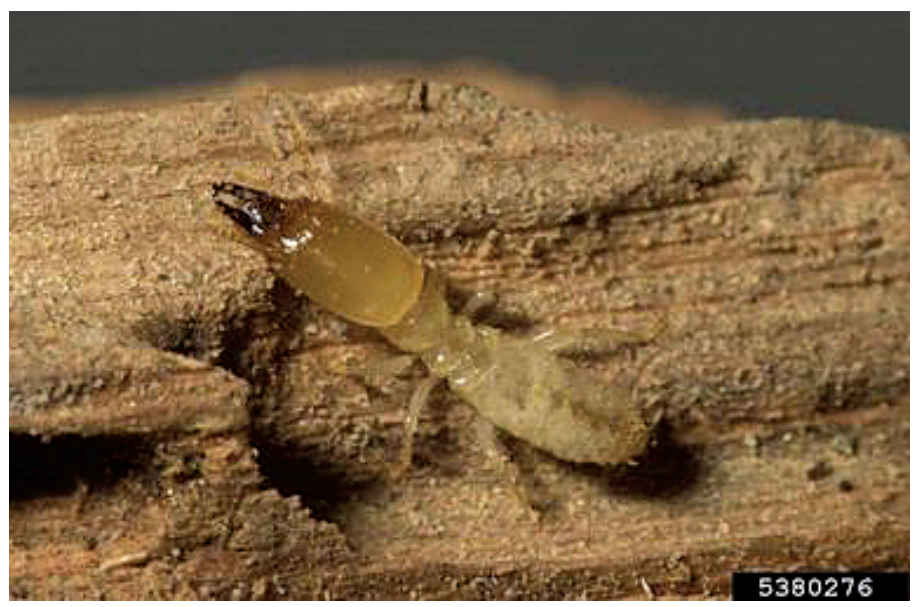

Credit: Gary Alpert, Harvard University, www.insectimages.org 


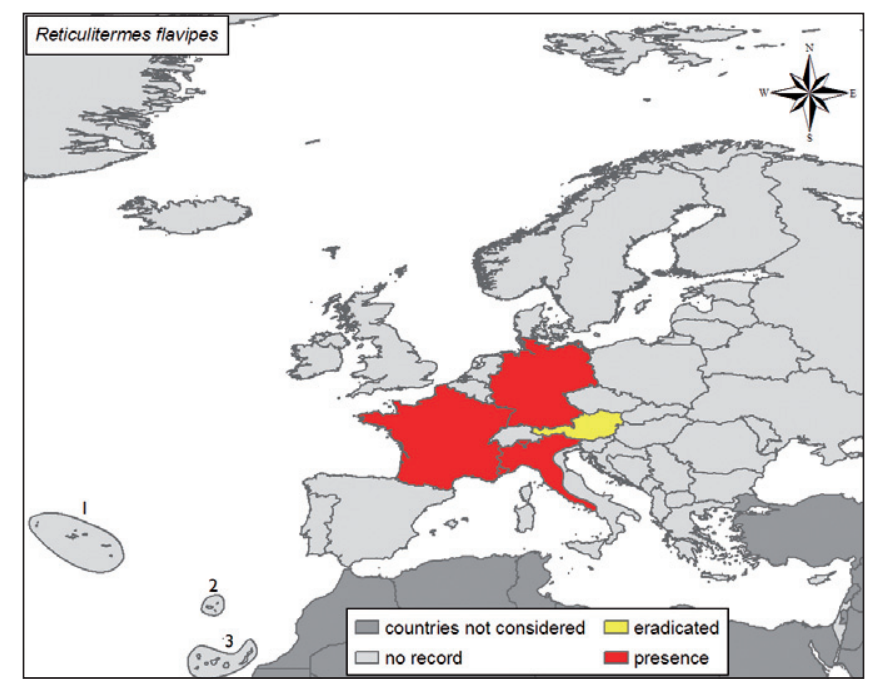

Introduced range: France, Germany and Austria (Map).

Pathways: Unknown.

Impact and management: Reticulitermes flavipes is particularly harmful to wooden elements in buildings but can also attack living trees, as observed with street trees in Paris recently. Reticultermes spp. have had huge economic impacts worldwide. In the USA, subterranean termites are believed to cause more than US $\$ 2$ billion in damage each year. In France, the recent spread of $R$. flavipes and Southern European species has caused major concern. New regulations were therefore set up to limit the spread. In nature, indigenous termites are beneficial, by recycling dead trees and other wood material. The impact of Reticulitermes spp. on the soil fauna and flora in newly invaded areas in Europe has not been studied. Management options are numerous and include both prevention and control methods. Building chemical or physical barriers can achieve prevention before and after construction (e.g. chemical wood treatment or steel mesh). Preventing moisture in the soil and in construction structures is an alternative strategy. Curative methods include termiticide injections, baits, trapping methods, etc.

\section{Selected references}

Szalanski AL, Scheffrahn RH, Messenger MT, Dronnet S, Bagnères AG (2005) Genetic evidence for the synonymy of two Reticulitermes species: Reticulitermes flavipes and Reticulitermes santonensis. Annals of the Entomological Society of America 98: 395-401.

Clément JL, Bagnères AG, Uva P, Wilfert 1, Quintana A, Reinhard J, Dronnet S (2001) Biosystematics of Reticulitermes termites in Europe: morphological, chemical and molecular data. Insectes Sociaux 48: 202-215.

Pearce MJ (1997) Termites. Biology and Pest management. Wallingford, UK: CAB Intenational. $172 \mathrm{pp}$. 


\subsection{4 - Hyphantria cunea Drury - Fall webworm (Lepidoptera, Arctiidae)}

Ferenc Lakatos

Description and biological cycle: Large white moth species with a wingspan of $19-30 \mathrm{~mm}$ (Photo left- see also Figure 11.6k-adult male and 11.6i-adult female in Chapter 11). Immature larvae feed gregariously, forming large webs on tree branches (Photo right). Mature larvae tend to be solitary feeders and consume the entire leaf leaving only the petiole. Highly polyphagous, with over 200 known host species including Acer negundo, Morus spp., Prunus spp., Malus spp. and even Populus and Quercus. Adults show remarkable dispersal powers. In Europe, there are up to three generations per year. In Japan, recent climate change has resulted in a shift from a bivoltine to a trivoltine life-cycle in at least a part of the range, together with significant changes in the length of the critical photoperiod for diapause induction. Overwinters as pupae. Adults emerge from mid April onwards and females lay 500 (spring generation) to 800 (summer generations) eggs, usually towards the top part of the host tree. Larvae produce 5-7 instars, feeding gregariously in a light web, except the first and last instars. Larval development takes 24-57 days, depending on climate and host nutrition conditions.

Native habitat (EUNIS code): G- Woodland and forest habitats and other wooded land.

Habitat occupied in invaded range (EUNIS code): G1 - Broadleaved deciduous woodland; G5- Lines of trees.

Native range: North America.

Introduced range: Two known introductions, the first one to Hungary during WW II (first individual found in 1940 in Budapest) and the second one in 1978 in Bordeaux, France.
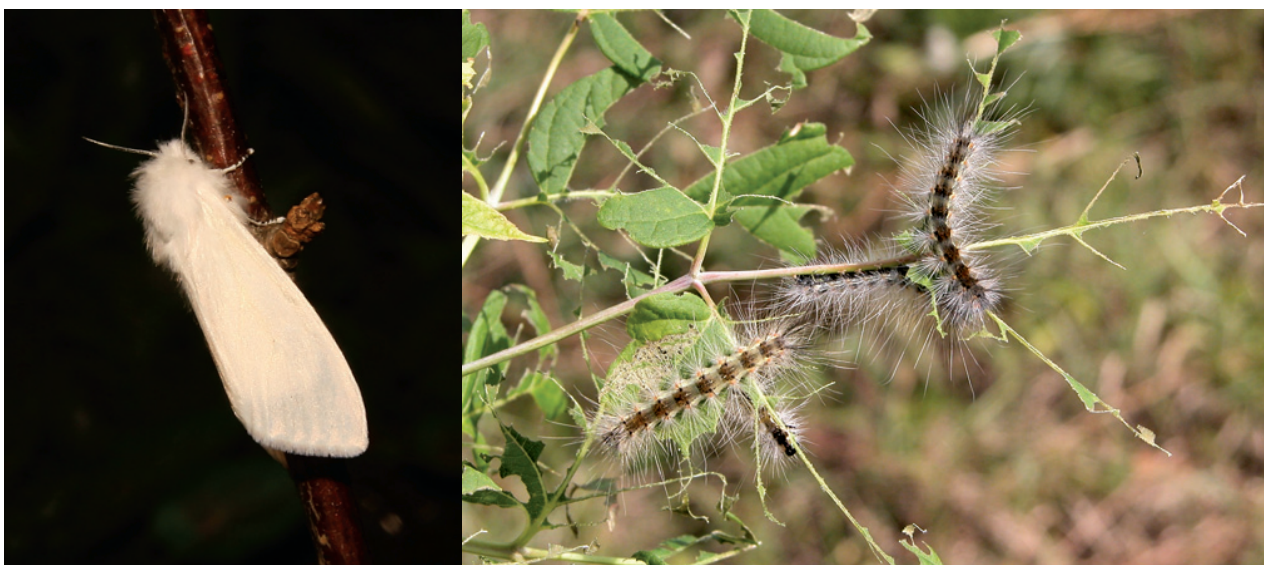


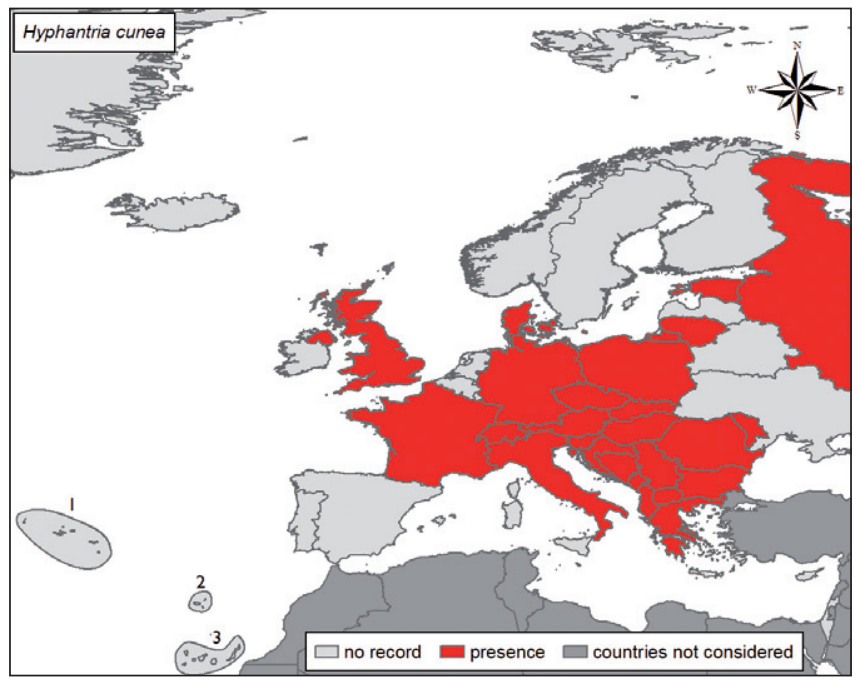

Nowadays, present in most of Europe, except UK, Scandinavia and Iberian Peninsula (Map).; also introduced to Japan and China.

Pathways: Probably trade of ornamental trees.

Impact and management: Threat to orchards, ornamentals and forest trees in some regions of Central and Eastern Europe, as well as in Eastern Asia. Particularly damaging to ornamentals; however, severe damage has occurred only during the expansion phase after establishment. It was a serious pest in Bulgaria, Romania, Hungary, former Yugoslavia, Russia and northern Italy. Nowadays frequent along roadsides, urban forests, parks and gardens. Constantly present in orchards, where the usual plant protection practices keep the population low. Heavy feeding by the caterpillars over time can lead to defoliation (leaf loss) and limb and branch die-back. Trees/ plants are often totally defoliated by late-instar larvae, particularly in the second generation. Environmental impacts are likely, given the high polyphagy and impact on individual plants. Natural enemies have already adapted to the species as well (e.g. Trichogramma, Tachina and Chalcidoidea, and even birds). Previously both mechanical (elimination of webs) and chemical (insecticide) controls were widely used, but nowadays, biological control (at least in the native habitats) plays a much more important role.

\section{Selected references}

Gomi T, Nagasaka M, Fukuda T, Hagihara H (2007). Shifting of the life cycle and life-history traits of the fall webworm in relation to climate change. Entomologia Experimentalis and Applicata 125: 179-84.

Rezbanyai-Reser L (1991) Hyphantria cunea Drury, 1773, und Noctua tirrenica Biebinger, Speidel \& Hanigk, 1983, im Südtessin, neu für die Schweiz (Lep.: Arctiidae, Noctuidae). Entomologische Berichte Luzern 26: 94-96, 135-152.

Torp R (1987) Ny dansk spinder: Hyphantria cunea Drury f. textor Harr. Lepidoptera 5: 83-86. 


\subsection{5 - Paysandisia archon (Burmeister, 1879) - The castniid palm borer (Lepidoptera, Castniidae)}

\section{Carlos Lopez-Vaamonde \& David Lees}

Description and biological cycle: Large dayflying moth with clubbed antennae, wingspan 75-120 mm, upperside forewing greenish brown in both sexes, hindwing bright orange with a black band postdiscal to white spots (Photo left). Forewing underside orange, excepting beige tips. Upright fusiform eggs, about $4.7 \mathrm{~mm}$. long and $1.5 \mathrm{~mm}$ wide, laid by the female's extensible ovipositor between mid-June and mid-October. Fertile eggs pink, laid among palm crown fibres, at the base of leaf rachis. Larvae hatch after $12-21 \mathrm{~d}$, whitish and grub-like, up to $9 \mathrm{~cm}$ long, endophytic cannibals, forming galleries $20-30 \mathrm{~cm}$ long inside palm trunks, towards the crown (Photo right). 7-9 larval instars, overwintering as larva, in a false cocoon. Pupation occurs at the rachis base or between inflorescences, where larvae form a cryptic cocoon of palm fibres, pupating for 43-66 d. Pupae remain attached to the cocoon after adult emergence. Adults observed from mid May to late September, males especially exhibiting powerful territorial flight in hot sunshine. Males live about $24 \mathrm{~d}$ and females about $14 \mathrm{~d}$. One generation per year (sometimes bivoltine) in Mediterranean locations. Larvae can live > 18 months and overall life cycle 13-22 months, exceptionally three years. Castniid palm borer infests a wide range of palm genera including Chamaerops, Latania, Livistona chinensis, Phoenix canariensis, Syagrus spp., Trithrinax campestris (probable import host), in the native area. Reported from Brahea, Butia, Chamaerops, Livistona spp. Phoenix spp., Sabal, Trachycarpus, Trithrinax campestris and Washingtonia, in the introduced area.

Native habitat (EUNIS code): G2 - Broadleaved evergreen woodland.

Habitat occupied in invaded range (EUNIS code): I2- Cultivated areas of gardens and parks; X24 Domestic gardens of city and town centres; J100- Greenhouses.

Native range: Neotropical region: western Uruguay, northwest Argentina, Paraguay and southeastern Brasil.

Introduced range: First introduced with its foodplant to Spain and France in the 1990's, well established by 2001 when first reported from Catalonia in Northeastern Spain. Rapidly spread

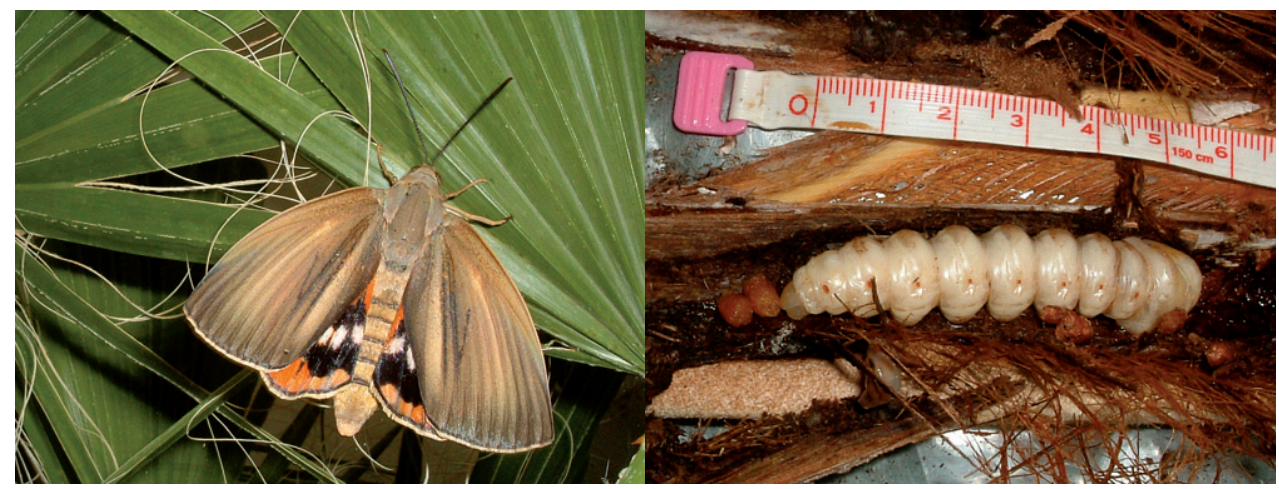




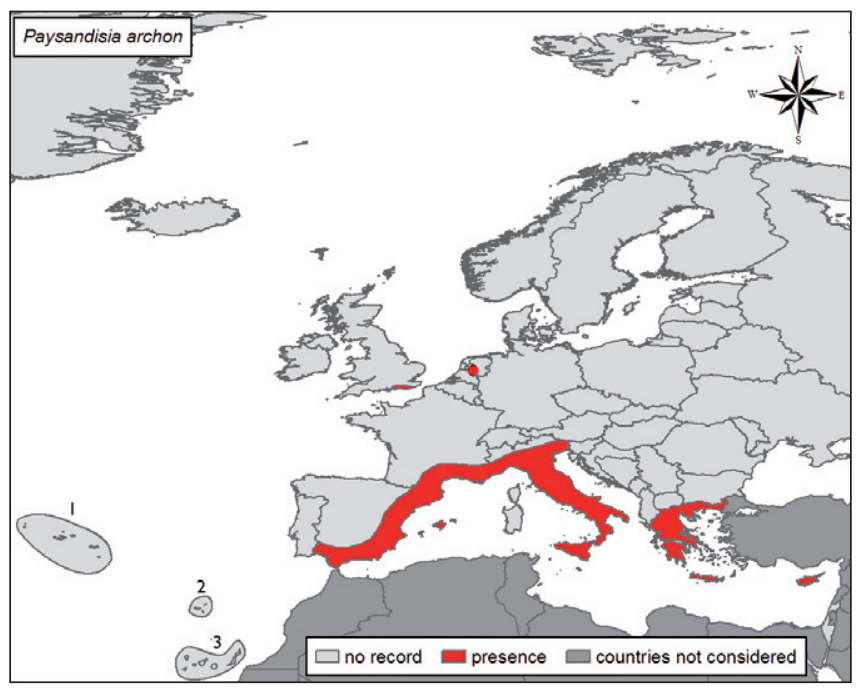

to coastal areas of the other Mediterranean regions where palms are widely used as ornamentals. Now common and widespread in Spain (along the Mediterranean coast from Girona to Alicante and the Balearic islands) southeastern France (Var and Hérault), Italy (Campania, Lazio, Toscana, Marche and Sicily), and in Greece mainland and Crete); also introduced in England (Sussex, one example in 2002) and Netherlands (one example in 2006) (Map). Spreading tendency.

Pathways: Introduced with trade of palm trees as ornamentals.

Impact and management: Pest species in parks and palm nurseries, causing severe damage (such as holes in leaves and deformation) and death of plants. Conservation concern exists for the native Mediterranean Fan Palm, Chamaerops humilis; numerous larvae may be found in one plant. Biological control in Europe is not yet achieved. As last resort, palms can be pulled up and burned. Chemical control of this species is also difficult since larvae are endophytes. Best control has been obtained by wetting crown and trunk with contact or systemic organophosphorus insecticides (Chlorpyrifos, Acephate and Dimethoate). Ostrinil (Beauveria bassiana147 strain) biological insectides normally used for the European Corn Borer cause egg and up to $80 \%$ larval mortality for crown treatment every two weeks during flight season, and can be used as a curative. Trials done with "glue" used as physical barrier (both preventing adult females from ovipositing and developing adults from emerging) have had positive results.

\section{Selected references}

Colazza S, Privitera S, Campo G, Peri E, Riolo P (2005) Paysandisia archon (Lepidoptera: Castniidae) a new record for Sicily. L'Informatore Fitopatologico 5: 56-57.

Hollingsworth T (2004) Status of Paysandisia archon (Burmeister) (Lepidoptera: Castniidae) in southern Europe. British Journal of Entomology and Natural History 17: 33-34.

Sarto i Monteys V (2002) The discovery, description and taxonomy of Paysandisia archon (Burmeister, 1880), a castniid species recently found in southwestern Europe (Castniidae). Nota Lepidopterologica 25: 3-16. 


\title{
14.66 - Diplopseustis perieresalis (Walker, 1859) - The exotic pyraloid moth (Lepidoptera, Crambidae)
}

\author{
Jurate De Prins \& Willy De Prins
}

Description and biological cycle: Small moth, wingspan $12-14 \mathrm{~mm}$, forewing greyish with some whitish transverse lines, indicated by separate dots; submarginal line more conspicuous; in some specimens, darker greyish antemedian transverse line, most visible towards inner margin (Photo). Termen* sinuous. Labial palps porrect* , a little longer than eye diameter. Hindwings whitish with greyish suffusion, dark marking in anal corner, transversed by white line parallel to wing margin. Biology undescribed, but larva supposed to live on Carex spp. Probably hibernating in larval stage.

Native habitat (EUNIS code): Unknown.

Habitat occupied in invaded range (EUNIS code): E3 - Seasonally wet and wet grasslands.

Native range: Oriental and Australasian regions: Australia, Brunei, China (coastal regions), Fiji, Hong Kong, India, Indonesia, Japan, Malaysia (Borneo, Sarawak), New Zealand, Taiwan.

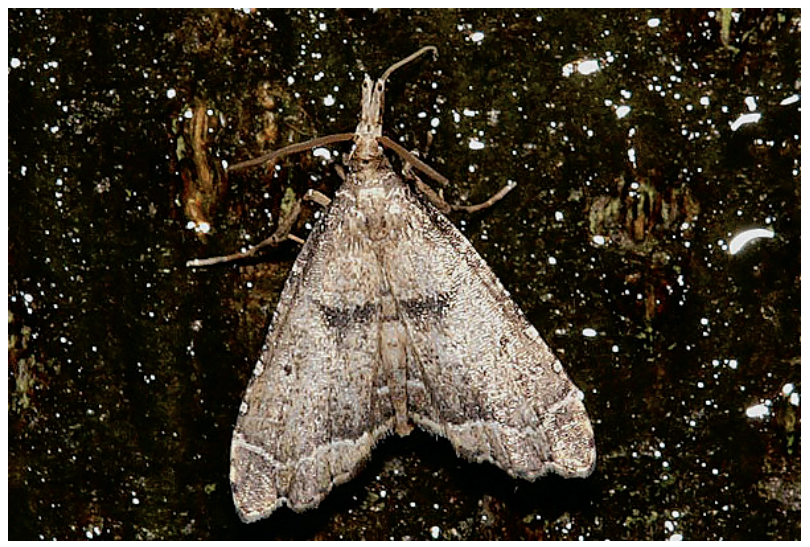

Credit: C. van den Berg 


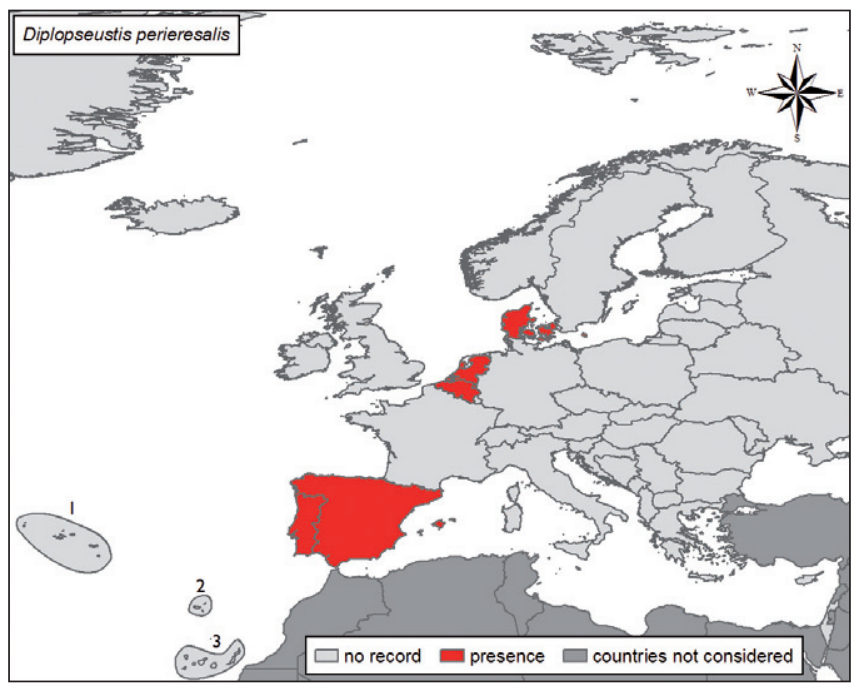

Introduced range: First recorded from Portugal in 2000. Then observed in several countries of western and Southern Europe: Belgium, Netherlands, Portugal, Spain (mainland, Balearic and Canary islands), United Kingdom (Scilly Islands) (Map).

Pathways: Long-distance dispersal probably human-mediated (plant trade between Australia, New Zealand, and Japan, and the Canary Islands), although the species has a strong dispersal power and could spread on its own. Spreading mode within Europe unknown.

Impact and management: Infestation rate still very low, no economic damage (Carex spp. are not commercially valuable). Neither chemical nor biological measurements necessary.

\section{Selected references}

Mackay A, Fray R (2002) Diplopseustis periersalis [sic] (Walker) on Tresco, Isles of Scilly - the first record for Britain and the western Palearctic region. Atropos 16: 26.

Speidel W, Nieukerken van EJ, Honey MR, Koster SJC (2007) The exotic pyraloid moth Diplopseustis perieresalis (Walker) in the west Palaearctic region (Crambidae, Spilomelinae). Nota Lepidopterologica 29: 185-192. 


\title{
14.67 - Phthorimaea operculella (Zeller, 1873) - Potato tuber moth (Lepidoptera, Gelechiidae)
}

\author{
Georgyi Trenchev and Katia Trencheva
}

Description and biological cycle: Adult small, light grey moth, about $10 \mathrm{~mm}$ long with wingspan of about $12 \mathrm{~mm}$ (Photo left-adult on potato). Greyish-brown wings patterned with small, dark specks. Larvae light brown with a brown head. Mature larvae reach 15-20 mm long, pink or greenish. Multivoltine, developing four or more generations per year, depending on climate conditions. In field conditions, adult, larva or pupa overwinters under crop residues in the upper layer of ground. In temperate climates, overwintering occurs mainly in storehouses. Adult moth emerges in spring, and found until the end of October. Moths are active after sunset. They lay eggs in groups of 2-3 or individually on the lower sides of plant leaves, sometimes on leafstalks, stems, exposed potato tubers, lumps of soil in the field, on potato tuber buds and on bags in storehouses. Female fecundity is 150-200 eggs. Embryonic development lasts 3-10 days. Larval development lasts for 11-14 days and passes through four instars. Pupal stage lasts 6-8 d. In storehouses, the pest develops continuously throughout the year.

Native habitat (EUNIS code): I- Regularly or recently cultivated agricultural, horticultural and domestic habitats.

Habitat occupied in invaded range (EUNIS code): I1 - Arable land and market gardens; I2-Cultivated areas of gardens and parks; J100- glasshouses.

Native range: Probably originates from South America.

Introduced range: Widely distributed worldwide, recorded in more than 70 countries. Known in Europe since the beginning of the 20th century, where it is mainly found in potato fields and storehouses (Map).

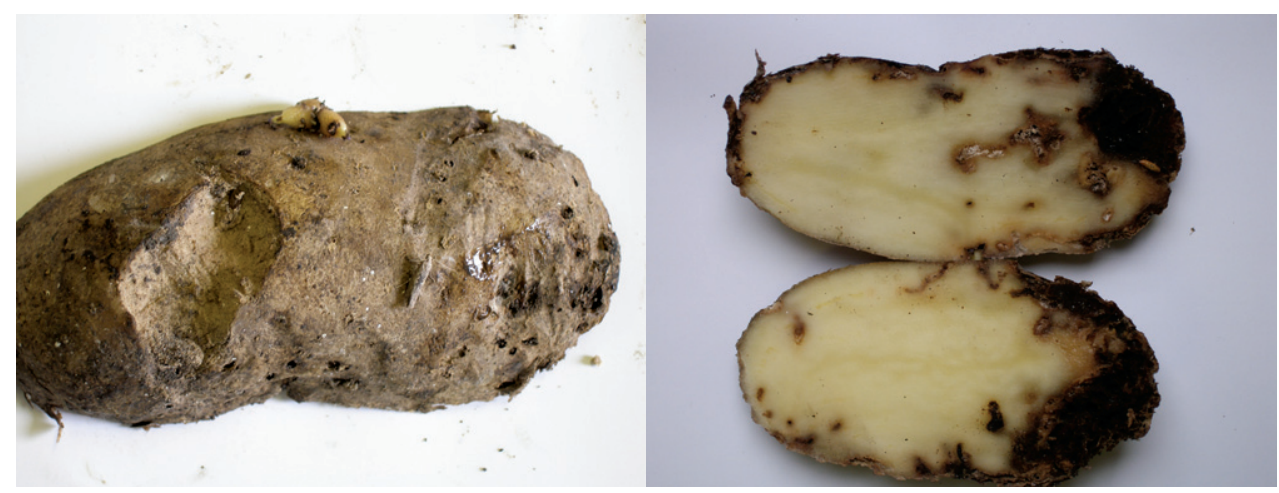

Credit: Katia Trencheva 


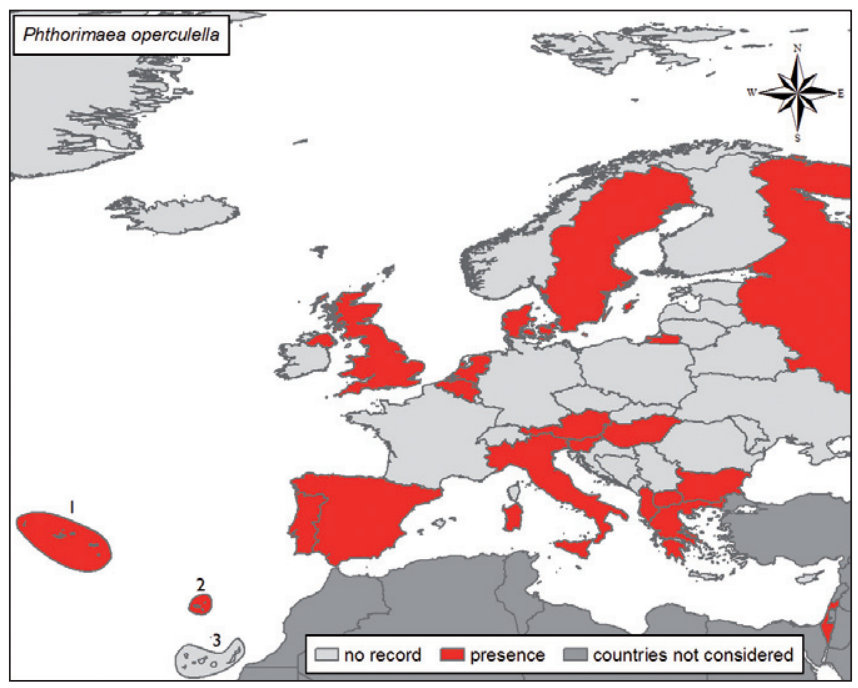

Pathways: Adults fly to potato fields over short distances and they can transported by wind. Over long distances, transportation occurs with infested tubers and re-infestation of fields then occurs from potato storehouses.

Impact and management: Damage is most frequent on stored tubers after the spring growing season and on young plants in the autumn growing season. Larvae bore holes and galleries in the tubers (Photo right). Larval penetration holes are unsightly and induce soft rot. Phthorimaea operculella can be a very serious potato pest, especially in tropical and sub-tropical regions, including the Mediterranean region. The attack results in lowered market value and quality of the infested tubers. Infestation may start early in the field, up to $15 \mathrm{~d}$ before tuber maturity. By harvest time, a substantial number of tubers may already be infested. This harvest-time infestation is responsible for the further development of infestation in stores. Integrated pest management methods have been developed in various parts of the world. Control measures include the use of pesticides; cultural practices include use of healthy tubers, irrigation or early harvest. Biological control is achieved through the introduction of parasitoids but also the use of Bt or Baculovirus, and through use of resistant varieties. Pheromones can be used both for monitoring and for control trapping in storage.

\section{Selected references}

CABI (2007) Crop Protection Compendium. CD-ROM. CAB International, Wallingford, UK. Das GP, Magallona ED, Raman KV, Adalla CB, 1992. Effects of different components of IPM in the management of the potato tuber moth, in storage. Agriculture, Ecosystems \& Environment 41: 321-325.

Trivedi TP, Rajagopal D, 1992. Distribution, biology, ecology and management of potato tuber moth, Phthorimaea operculella (Zeller) (Lepidoptera: Gelechiidae): a review. Tropical Pest Management, 38: 279-285. 


\title{
14.68 - Cameraria obridella Deschka \& Dimić, 1986 - Horse chestnut leaf-miner (Lepidoptera, Gracillariidae)
}

\author{
Sylvie Augustin
}

Description and biological cycle: Tiny moth, 3-5 mm long, forewing background orangebrown with basal white longitudinal streak and white v-marks bent towards costa and running straight across dorsum at rest, edged posteriorly in black, two of these fasciae continuous medially, one post-medial fascia interrupted and a final convex fascia towards wing apex, bisected by a diffuse blackish subapical streak (Photo left- see also Figure 11.7c in Chapter 11). Fringe forming a conspicuous orange tuft that is longest dorsally at rest. Head tufted with orange hair-like scales intermixed with white, scape and base of antenna silvery white. Antennae about 4/5 forewing length. Phytophagous larvae, mining leaves of white-flowered horse chestnut Aesculus hippocastanum; but can also develop on other Aesculus species and occasionally on maples, Acer pseudoplatanus and A. platanoides. Leaf mines from April onwards; an average of 75 eggs are laid per female on the upper epidermis of horse-chestnut leaves. Produces four (rarely five) mining and two spinning larval instars; usually three generations per year in W Europe, but up to five overlapping generations depending on weather conditions and climate. Pupae diapause in leaves.

Native habitat (EUNIS code): G1 - Broadleaved deciduous woodland.

Habitat occupied in invaded range (EUNIS code): G1 - Broadleaved deciduous woodland; I2 - Cultivated areas of gardens and parks; X13 - Land sparsely wooded with broadleaved deciduous trees; X11 - Large parks; J - Constructed, industrial and other artificial habitats.

Native range: Southern Balkans.

Introduced range: Most of Europe, except part of Northern Europe and Western Russia (Map). Increasing its distributional range and abundance in newly colonized areas.

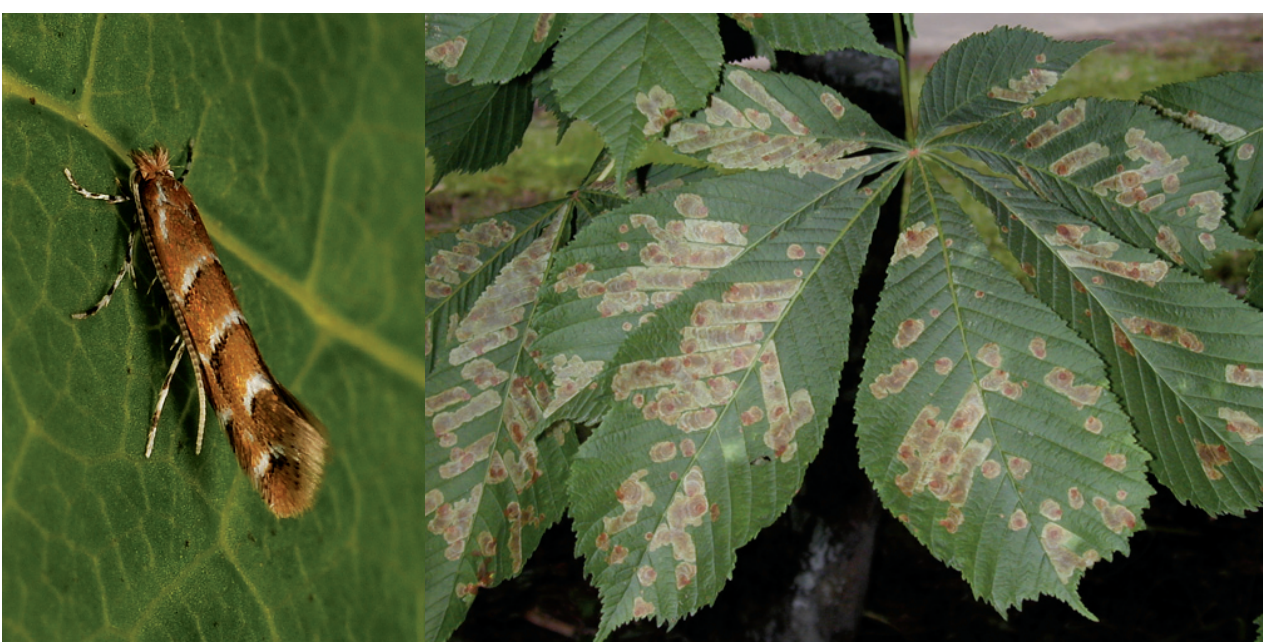




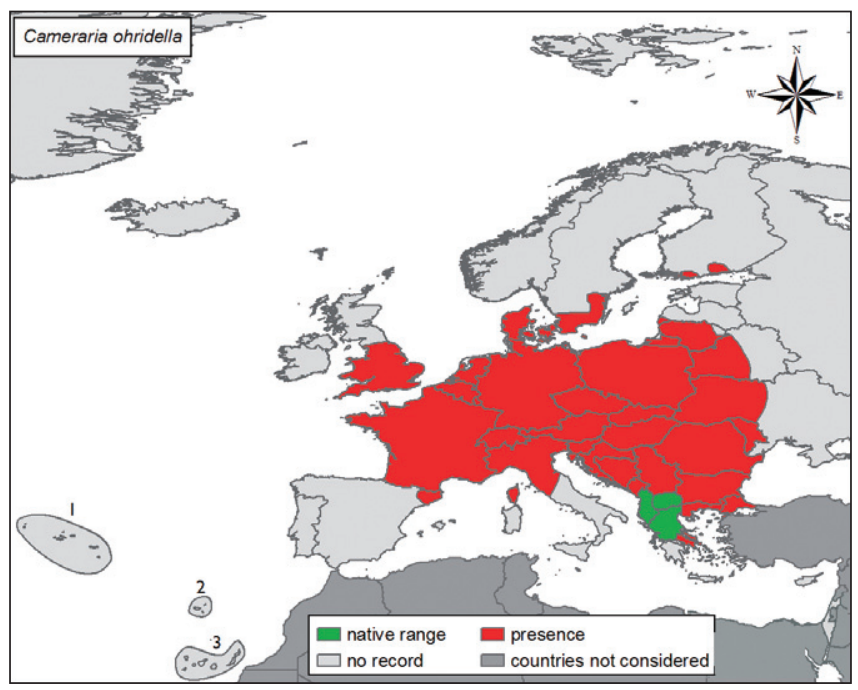

Pathways: Adult moths are transported by wind. Anthropogenic transport occurs by vehicles, in infested leaf fragments or infested nursery stock.

Impact and management: Severely defoliated trees produce smaller seeds with a lower fitness that affects tree regeneration and seriously impairs recruitment of horse chestnut in the last endemic forests in the Balkans. A single leaf can host up to 106 leaf-miners (Photo right). Parasitism rates low, as most parasitoids emerge when larvae or pupae are not yet available; this may have an important impact on native leaf-miners. There is significant public concern because of aesthetic impact. Main costs are caused by by removal or replacement of severely damaged horse chestnut trees planted in cities and villages. Complete removal of leaf litter, in which pupae hibernate, is the only effective measure available to lessen damage. The majority of adults can be prevented from emerging when leaves are properly composted (e.g., mulching of horse chestnut leaves with a layer of soil or uninfested plant material). Chemical control: aerial spraying with dimilin is efficient; spraying with Fenoxycarb combined with a surfactant has proved effective. Other "biological pesticides" with fewer non-target effects, such as neem, are also feasible, but their efficiency is considered to be lower. Stem injection is also efficient, but is not widely registered. This injures trees through necrosis and infections, and systemic insecticide may cause side effects on non-target species such as honey bees.

\section{Selected references}

Gilbert M, Grégoire J-C, Freise J, Heitland W (2004) Long-distance dispersal and human population density allow the prediction of invasive patterns in the horse-chestnut leafminer Cameraria ohridella. Journal of Applied Ecology 73: 459-468.

Lees DC, Lopez-Vaamonde C, Augustin S (2009) Cameraria ohridella Deschka \& Dimić 1986. http://eolspecies.lifedesks.org/pages/8675.

Valade R, Kenis M, Hernandez-Lopez A, Augustin S, Mena NM, Magnoux E Rougerie R, Lakatos F, Roques A, Lopez-Vaamonde C (2009) Mitochondrial and microsatellite DNA markers reveal a Balkan origin for the highly invasive horse-chestnut leaf miner Cameraria ohridella (Lepidoptera, Gracillariidae). Molecular Ecology 18: 3458-3470. 


\subsection{9 - Parectopa robiniella (Clemens, 1863) - Locust Digitate Leafminer (Lepidoptera, Gracillariidae)}

\section{David Lees}

Description and biological cycle: Small moth, wingspan 5.73-7.26 mm. Forewing background dark orange with four white curved flecks outlined in fuscous, running from costa and tergal edge of forewing in an interdigitate fashion towards middle of wing; white costal mark in between most apical flecks. Hindwing mid brownish with brownish cilia tipped apically in white (see Figure 11.6b in Chapter 11). Hindlegs conspicuously banded brown and white. Mine starts close to base of leaf with egg laid on underside, at the base of a fork made by the veins, where the larva bores through to upperside and forms a distinctive whitish digitate shape, straddling the midrib (Photo), unlike Phyllonorycter robiniella, which may precede it by about two weeks, and in U.S.A., Chrysaster ostensackenella Fitch. Larva greenish and solitary, leaf-miner on Black Locust (or False Acacia) trees Robinia pseudacacia and R. hispida, and on other Fabaceae including Amorpha fruticosa, Galactia volubilis and Desmodium sp. Leaf-mines and adult flight occurs from June to October (in two, sometimes overlapping, generations). Larva pupates in leaf litter on ground, in contrast to Phyllonorycter robiniella, and probably thus less susceptible to parasitism.

Native habitat (EUNIS code): G- Woodland, forest and other wooded land.

Habitat occupied in invaded range (EUNIS code): G5 - Lines of trees, small anthropogenic woodlands, recently felled woodland, early-stage woodland and coppice; I- Regularly or recently cultivated agricultural, horticultural and domestic habitats; I2- Cultivated areas of gardens and parks; X24- Domestic gardens of city and town centres.

Native range: North America (Canada: Québec), U.S.A. (Florida, Kentucky, Maine, Maryland, Michigan, Missouri, New Orleans, New York, Pennsylvania, Vermont, Wisconsin)

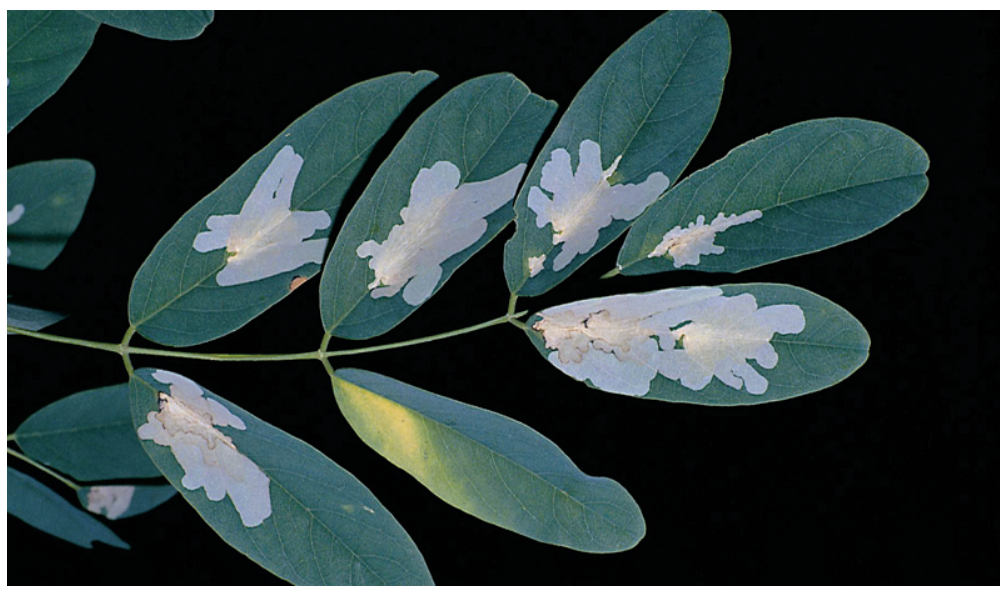

Credit: György Csóka 


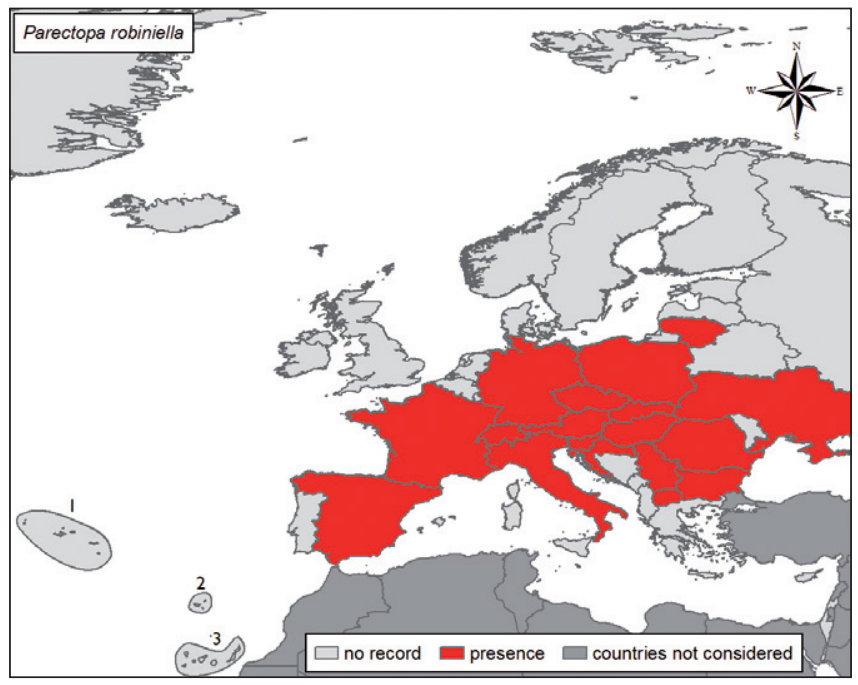

Introduced range: First observed in Europe in Italy in 1970, Locust Digitate Leafminer has spread relatively quickly in various directions to Western and Central Europe and to the Balkans (Map).

Pathways: Unknown, possibly via plant trade.

Impact and management: Causes damage to false acacia trees including leaf drop as early as June in cases of severe infestation. Potential impact on ornamental trees and industrial plantations. Natural control includes at least 20 species of wasps in Braconidae (Pholetesor circumscriptus, P. nanus), Chalcidoidea Encyrtidae (Ageniaspis sp.), Eupelmidae (Eupelmus urozonusi), Eulophidae (Achrysocharoides cilla, Astichus trifasciatipennis, Chrysocharis nitetis, Cirrospilus viticola, Closterocerus cinctipennis, C. formosus, C. trifasciatus, Elachertus inunctus, Holcothorax testaceipes, Hyssopus benefactor, Minotetrastichus frontalis, Neochrysocharis formosa, Pediobius saulius, Pnigalio pectinicornis, P. soemius, Sympiesis acalle, S. marylandensis, S. sericeicornis and Ichneumonidae (Gelis acarorum, Diadegma sp.), but parasitism levels may be too low to have much impact. As for Phyllonorycter robiniella, parasitoids have easily shifted from other hosts, but this species has been less susceptible.

\section{Selected references}

Ivinskis P, Rimsaite J (2008) Records of Phyllonorycter robiniella (Clemens, 1859) and Parectopa robiniella Clemens, 1863 (Lepidoptera, Gracillariidae) in Lithuania. Acta Zoologica Lituanica 18: 130-133.

Lakatos F, Kovács Z, Stauffer C, Kenis M, Tomov R, Davis DR (2003) The Genetic Background of Three Introduced Leaf Miner Moth Species - Parectopa robiniella Clemens 1863, Phyllonorycter robiniella Clemens 1859 and Cameraria obridella Deschka et Dimic 1986. In: Proceedings: IUFRO Kanazawa (2003) "Forest Insect Population Dynamics and Host Influences", 67-71. 


\subsection{0 - Phyllonorycter issikii (Kumata, 1963) (Lepidoptera, Gracillariidae)}

\section{David Lees}

Description and biological cycle: Small moth, wingspan 7.0-7.5 mm. Thorax and forewing ground colour golden to light brownish ochreous, with blackish stripes and three white stripes in summer form (see Figure 11.6d in Chapter 11), dusted with white scales in autumn form (see Figure 11.6c in Chapter 11), well camouflaged for hibernation; hindwings pale grey, cilia tinged with yellow. Adult resembles Phyllonorycter corylifoliella, but male genitalia highly asymmetric, right valve especially wide and left one slender. Eggs oblong, greenish, about $0.24 \times 0.35$ $\mathrm{mm}$. Larva yellowish towards caudal end and white toward head. Leaf-miner on lower surface (Photo) of small-leaved Lime Tilia cordata, Tilia platyphyllos or various crosses such as Tilia $\mathrm{x}$ vulgaris (Tiliaceae), with adults flying in two generations at end of April and May and AugustSeptember (in Europe). Oligophagous on Tilia, apparently without strong preference. Feeds on T. maximowicziana, T. kiusiana and T. japonica (in Japan), T. amurensis (far eastern Russia) and T. mandshurica (in Korea). Development: egg, 4-8 d, larva in five instars, the last two tissue feeding, 13-40 d, pupa 10-15 d. Prefers trees in understory/shade. Mine when unfolded showing micro-ridges, elliptical to oblong, whitish, on underside of leaf, usually at fork of primary or secondary veins, with frass piled up at one end. Hibernates as adult.

Native habitat (EUNIS code): G - Woodland, forest and other wooded land.

Habitat occupied in invaded range (EUNIS code): G5 - Lines of trees, small anthropogenic woodlands, recently felled woodland, early-stage woodland and coppice; I - Regularly or recently cultivated agricultural, horticultural and domestic habitats; I2 - Cultivated areas of gardens and parks; X24 - Domestic gardens of city and town centres. Spreading quite rapidly westwards especially after 2000 .

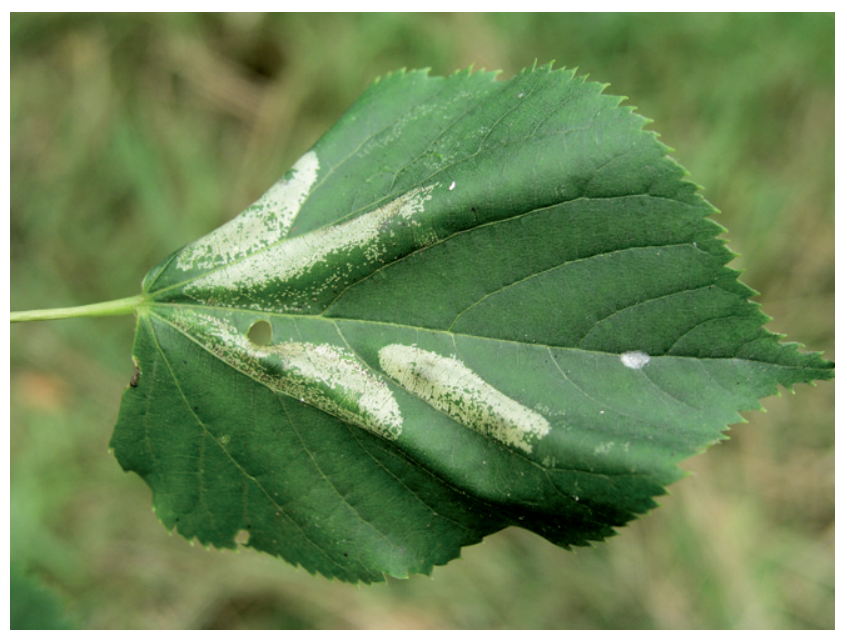




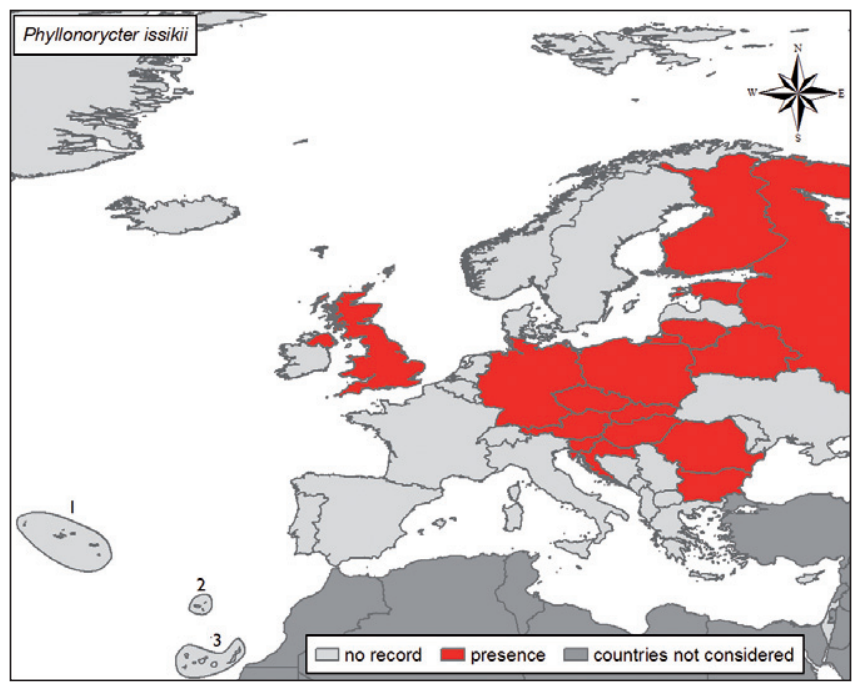

Native range: Japan (Hokkaidô, Honshũ, Kyũshũ) and probably also in far eastern Russia eastern China and Korea (where first reported 1977).

Introduced range: First reported from Moscow in 1985, Phyllonorycter issikii spread to the Baltic countries of the Baltic countries and most of Central Europe (Map and Šefrová (2002) for a review of spread in Europe).

Pathways: Apparently spread by wind and possibly also by horticultural trade and passive spread of hibernating adults, since the distance between eastern and western Russia seems too large for possible long distance aerial transport.

Impact and management: Causes damage including limited leaf folding to lime trees. Potential aesthetic impact to park and garden trees is relatively minor, since sunny branches are avoided, and no native Tilia populations are threatened. Natural controls include the chalcidoid eulophid wasp parasitoids Chrysocharis laomedon, Mischotetrastichus petiolatus, Pediobius saulius, Pleuroppopsis japonica, Sympiesis laevifrons and S. sericeicornis, but biological control seems unnecessary, since parasitoid levels attained $20 \%$ in some localities even the year after arrival in eastern Europe.

\section{Selected references}

Ermolaev IV, Motoshkova NV (2008) Biological invasion of the Lime Leafminer Lithocolletis issikii Kumata (Lepidoptera, Gracillariidae): interaction if the moth with the host plant. Entomological Review, 88: 1-9.

Noreika R (1998) Phyllonorycter issikii (Kumata) (Lepidoptera, Gracillariidae) in Lithuania. Acta Zoologica Lituanica 8: 34-37.

Šefrová H (2002) Phyllonorycter issikii (Kumata, 1963) - bionomics, ecological impact and spread in Europe (Lepidoptera, Gracillariidae). Acta Universitatis Agriculturae et Silviculturae Mendelianae Brunensis 50: 99-104. 


\subsection{1 - Phyllonorycter platani (Staudinger, 1870) (Lepidoptera, Gracillariidae)}

\section{David Lees}

Description and biological cycle: Small moth, wingspan $8-10 \mathrm{~mm}$. Adult forewing light golden-orange, with silvery white markings: mediobasal stripe to a third of forewing length, longer white stripes running along costa and tergum; narrow transverse medial band at $2 / 3$ that may be divided; apically two costal and two dorsal streaks that may meet in middle of wing and are basal to a small black apical eyespot (see Figure 11.6f in Chapter 11). Asymmetric male genitalia, left valve at least twice as broad as right. Larva yellowish white, up to $7 \mathrm{~mm}$ long. Leafminer on Platanus orientalis, P. racemosa, P. occidentalis, P. acerifolia, P. hispanica and commonly in urban areas on Platanus $\mathrm{x}$ hispanica (Platanaceae) ("London Plane"). Mine a large distinctive blotch commencing in a sinuous pattern, usually on underside of leaf, between veins, appears brownish underneath, mottled upperside, and semi-transparent against sky (Photo left-mine on Platanus leaf; Photo right-mine opened to show third-instar larva). Pupa light brown, pupates in a whitish cocoon within leaf on ground. Adults on wing between April and September, in two generations, with larvae of summer generation diapausing.

Native habitat (EUNIS code): Unknown

Habitat occupied in invaded range (EUNIS code): G5 - Lines of trees, small anthropogenic woodlands, recently felled woodland, early-stage woodland and coppice; I - Regularly or recently cultivated agricultural, horticultural and domestic habitats; I2 - Cultivated areas of gardens and parks; X24 - Domestic gardens of city and town centres.

Native range: Unknown, but possibly Balkans; described from Italy.

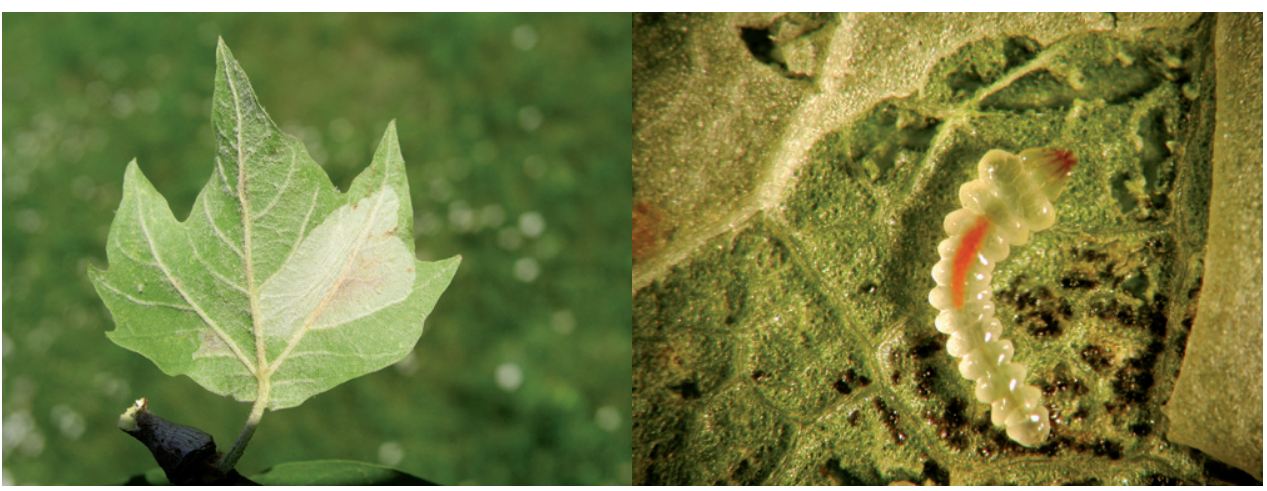

Credit: Hana Šefrová 


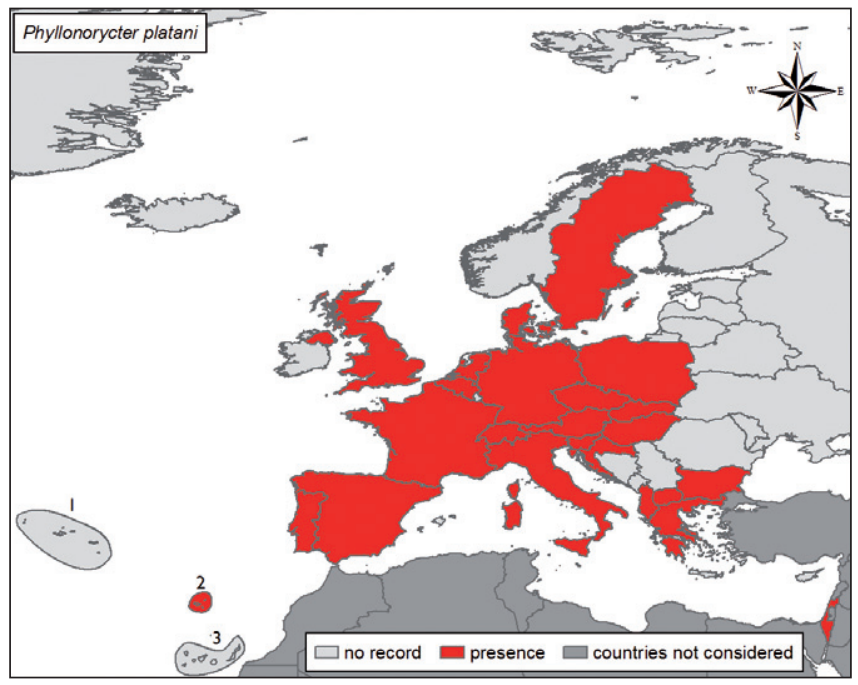

Introduced range: Recorded in most European countries wherever Platanus trees have been planted (Map and Šefrová (2001) for a review of its dispersal history in Europe). Also introduced in central Asia (Kazakhstan, Tajikistan, Turkmenisatn), Asia Minor (Iran, Syria), and apparently in the USA (California).

Pathways: Passive dispersal via fallen leaves has greatly facilitated the rapid spread of Phyllonorycter platani.

Impact and management: Causes damage to plane trees, rarely unsightly, as leaves remain green, but sometimes reaching a density of 60 mines per leaf. Therefore of potential, but not usually severe, aesthetic impact. Leaves can be gathered up and burned. Chemical control not recommended nor necessary. Natural control by parasitoid wasps: at least 57 spp. recorded, including families Braconidae (genera Apanteles, Colstus, Pholeteor), Chalcididae (Conura), Encyrtidae (Ageniaspis); Eulophidae (Achrysocharoides, Aprostocetus, Chrysocharis, Cirrospilus, Clostocerus, Diglyphyus, Elachertus, Eulophus, Horismenus, Minotetrastichus, Pediobius, Pnigalio, Sympiesis); Ichneumonidae (Itoplectis, Pimpla, Scambus, Triclistus); Pteromalidae: Chlorocytus, Conomorium, Pteromalus); Torymidae (Torymus).

\section{Selected references}

Frankenhuyzen Av (1983) Phyllonorycter platani (Staudinger, 1870) (Lep.: Gracillariidae), een bladmineerder op plataan in Nederland. Entomologische Berichten 43: 19-25.

Šefrová H (2001) Phyllonorycter platani (Staudinger) - a review of its dispersal history in Europe

(Lepidoptera, Gracillariidae). Acta Universitatis Agriculturae et Silviculturae Mendelianae Brunensis 49: 71-75. 


\subsection{2 - Phyllonorycter robiniella (Clemens, 1859) (Lepidoptera, Gracillariidae)}

\section{David Lees}

Description and biological cycle: Small moth, wingspan 5.98-6.37 mm. Adult forewings light orange with four silvery-white diagonal striae running from costa towards tergal edge, but reflexed at middle of wing, at least the terminal one divided, apically a black eyespot; base of wings silvery white (see Figure 11.6g in Chapter 11). Larva in Europe a leaf-miner of Robinia pseudacacia (Fabaceae) (in North America using also R. hispida, R.viscosa and $R$. neomexicana, but not recorded on other genera), from June to October, in two or usually three generations from June to October in Europe. Diaphanous whitish, tentiform blotch mine that does not traverse midrib, but may occupy a large part of one side of the leaf, usually on underside (Photo), occasionally on leaf upperside, and which may sometimes merge to contain up to 15 larvae. Egg, light greenish grey, 6-10 $\mathrm{d}$, larva, hypermetamorphic, in final two of five tissue-feeding instars, cylindrical, 20-50 d, pupa in oval white cocoon within the mine 7-20 d, 5-11 weeks for development. Hibernates as adult.

Native habitat (EUNIS code): G - Woodland, forest and other wooded land.

Habitat occupied in invaded range (EUNIS code): I - Regularly or recently cultivated agricultural, horticultural and domestic habitats; I2 - Cultivated areas of gardens and parks.

Native range: Nearctic: Eastern and central USA (North America), throughout the native range of Robinia pseudacacia, including Canada (Québec), U.S.A (Connecticut, Florida, Illinois, Kentucky, Maine, Maryland, Massachusets, Michigan, New York, Texas, Vermont, and Wisconsin).

Introduced range: First recorded in Europe in 1983 in Switzerland, it then invaded most of Western, Central and Northern Europe: Austria, Belgium (from 2000), Croatia, Czech Republic, France, Germany, Hungary, Italy (1988), The Netherlands (1999), Poland, Slovakia, Spain (Barcelona 2000), Switzerland (1983), Ukraine. Apparently spreading faster eastwards than westwards (Map).

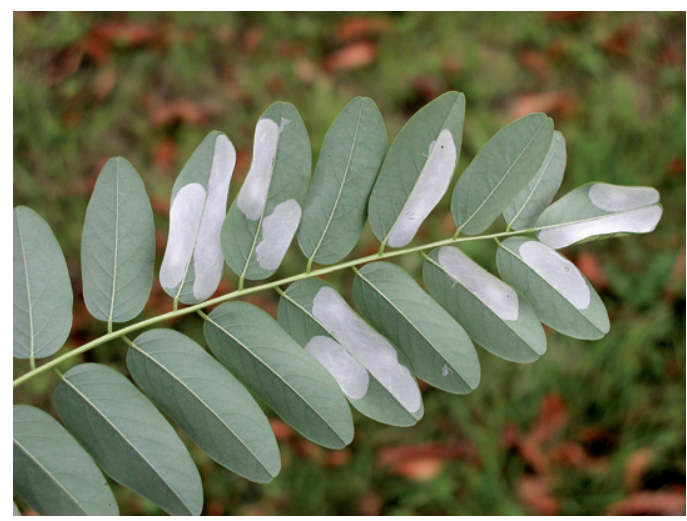

Credit: Hana Šefrová 


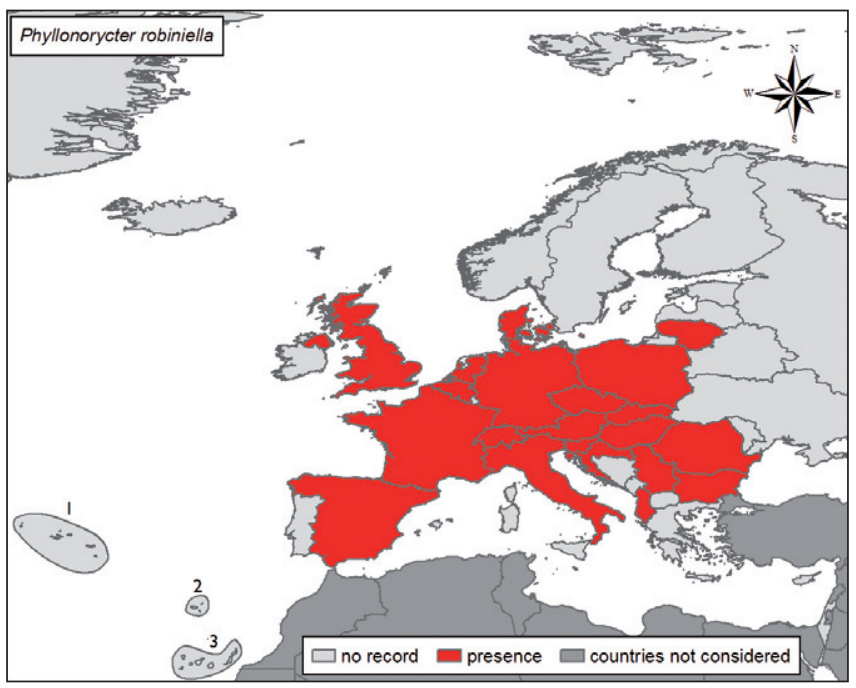

Pathways: Passive wind dispersal may be unusually important for this species, as although leaves can be carried by cars, pupae hatch before leaf fall, making leaf transport more more unlikely than for some other gracillariid species.

Impact and management: Causes premature leaf drop to false acacia trees and thus has potential aesthetic and physiological impact. Reported to have a higher surface area impact on industrial plantations than Parectopa robiniella. Damage must be weighed against considerations that false acacia is itself an undesirable alien in some European ecosystems. Chitin synthesis inhibitors applied in late May could cure leaf drop. Natural control includes at least 22 species of (polyphagous) braconid (Apanteles nanus, Colastes braconius, Pholetesor bicolor, P. circumscriptus, P. ornigis), and chalcidoid eupelmid and eulophid wasps (Achrysocharoides cilla, A. gahani, Astichus trifasciatipennis, Baryscapus nigroviolaceus, Chrysocharis nephereus, Closterocerus cinctipennis, C. trifasciatus, Elachertus inunctus, Horismenus fraternus, Minotetrastichus frontalis, $M$. platanellus, Pediobius liocephalatus, $P$. saulius, Pnigalio pectinicornis, $P$. soemius, Sympiesis acalle, S. marylandensis and S. sericeicornis). Parasitoids have easily shifted from other hosts.

\section{Selected references}

De Prins W, Groenen F (2001) Phyllonorycter robiniella, een nieuwe soort voor de Belgische fauna (Lepidoptera: Gracillariidae). Phegea 29: 159-160.

Ivinskis P, Rimsaite J (2008) Records of Phyllonorycter robiniella (Clemens, 1859) and Parectopa robiniella Clemens, 1863 (Lepidoptera, Gracillariidae) in Lithuania. Acta Zoologica Lituanica 18: 130-133.

Šefrová H (2002) Phyllonorycter robiniella (Clemens, 1859) - egg, larva, bionomics and its spread in Europe (Lepidoptera, Gracillariidae). Acta Universitatis Agriculturae et Silviculturae Mendelianae Brunensis 50: 7-12. 


\subsection{3 - Cacyreus marshalli (Butler, 1898) - Geranium bronze (Lepidoptera, Lycaenidae)}

Jurate De Prins \& Willy De Prins

Description and biological cycle: Small butterfly, wingspan 15-27 mm, upperside forewing brown in both sexes, fringes checkered, hindwing with short tail and conspicuous dark spot close to tail (Photo left), upperside thus resembling Lampides boeticus (L.). Hindwing fringe pure white with sometimes a narrow, interrupted brown line in the middle. Underside unlikely to be confused with any other European lycaenid. Eggs are laid on the flowers buds or the underside of the leaves of Pelargonium spp. Larvae feed mainly on the flowers and flower buds, but also other parts of the foodplant are consumed. First two instars are obligate endophytes in the flower buds, young shoots or leaves; the last three instars are facultative endophytes in all plant tissues, except the roots, but they may also occur as external feeders. Pupation inside the stem or among leaf litter at the base of the foodplant (Photo right-pupae). No photoperioddriven diapause. The species cannot survive severe winters in Central Europe outdoors, but it can complete its life cycle during summer time in this region. Also, it often survives the winter season because geraniums are often put inside at this time, when development is slowed down. Five to six generations per year in Mediterranean locations. Closely associated to Pelargonium in the native range.

Native habitat (EUNIS code): I2- Cultivated areas of gardens and parks.

Habitat occupied in invaded range (EUNIS code): I1 - Arable land and market gardens; I2- Cultivated areas of gardens and parks.

Native range: Afrotropical region: South Africa.

Introduced range: First introduced with its foodplant to the Balearic Island of Mallorca at the end of the 1980s. Spread fast to the other Balearic islands and the coastal regions of

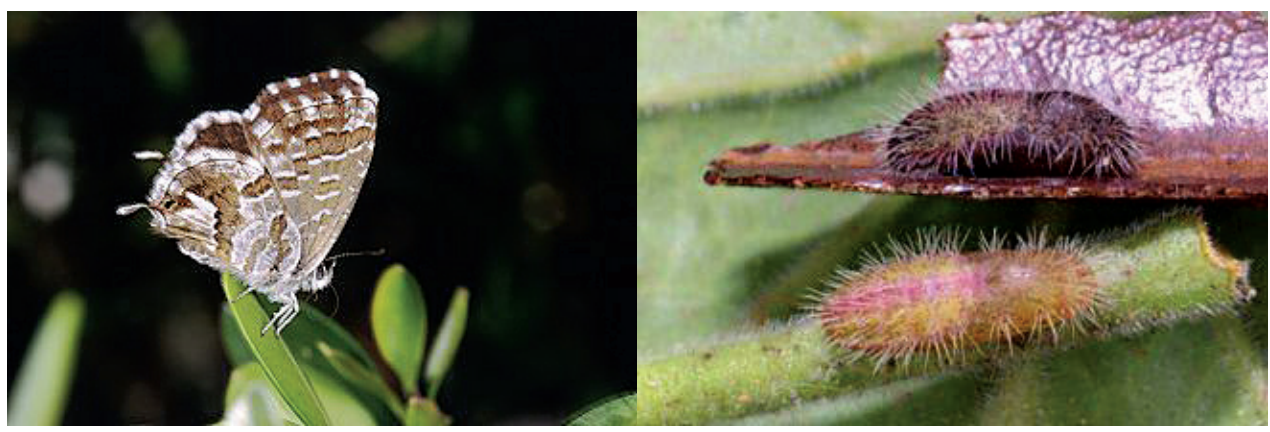

Credit: Paolo Mazzei 


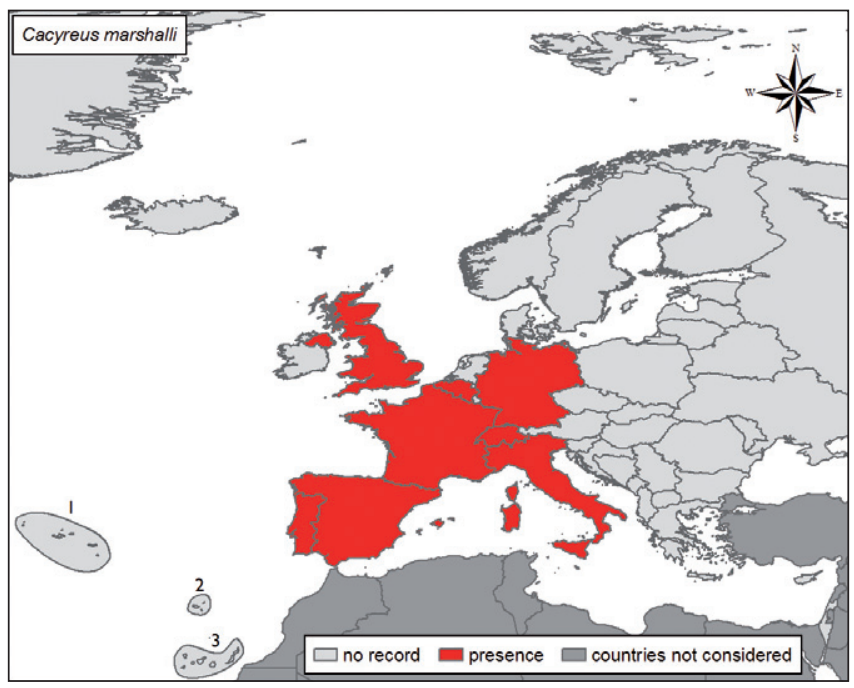

the West-Mediterranean, where geraniums (Pelargonium spp.) are widely used as ornamentals. At present common and widely spread in the Mediterranean basin (France common north to Lyon, Italy, Portugal, Spain mainland and Balearic Islands) but rare and isolated records in Central Europe (Belgium, Germany, Netherlands and Switzerland) and United Kingdom (southern coast) (Map). Also introduced in Morocco. Spreading tendency.

Pathways: trade of ornamental geraniums (Pelargonium spp.)

Impact and management: Pest species in geranium nurseries, causing severe damage and even death of plants. In laboratory conditions, oviposition has been observed on native European Geranium species (e.g. G. pratense, G. sylvaticum), and hence Cacyreus marshalli represents a potential threat for both native geraniums and for other Geranium-consuming lycaenids, such as Aricia nicias (Meigen) and Eumedonia eumedon (Esper). Trials with several insecticides on the island of Mallorca had positive results. Since 1995, no autochthonous parasitoids have been reared from Cacyreus marshalli.

\section{Selected references}

Holloway J (1998) Geranium bronze Cacyreus marshalli Atropos 4: 3-6.

Quacchia A, Ferracini C, Bonelli S, Balletto E, Alma A (2008) Can the Geranium Bronze, Ca-

cyreus marshalli, become a threat for European biodiversity? Biodiversity and Conservation 17: $1429-1437$.

Sarto i Monteys V (1992) Spread of the Southern African Lycaenid butterfly, Cacyreus marshalli

Butler, 1898, (LEP: Lycaenidae) in the Balearic Archipelago (Spain) and considerations on its likely introduction to continental Europe. Journal of Research on the Lepidoptera 31: 24-34. 


\title{
14.74 - Spodoptera littoralis (Boisduval, 1833) - African cotton leaf worm (Lepidoptera, Noctuidae)
}

\author{
Carlos Lopez-Vaamonde
}

Description and biological cycle: Polyphagous moth, up to $2 \mathrm{~cm}$ long with wingspan of 4 $\mathrm{cm}$ (Photo left); eggs laid in batches covered with orange-brown hairs. The neonate larva is pale green with a brownish head; when fully developed, larvae 35-45 mm long, body colour varying from grey to reddish or yellowish, with a median dorsal line bordered on either side by two yellowish-red or greyish stripes, and small yellow dots on each segment (Photo right-mature larva on a tomato leaf). 1000-2000 eggs laid per female 2-5 d after emergence; egg masses of 100-300 on the lower leaf surface of host plants. Life cycle lasts 19-144 days. Larvae are extremely sensitive to climatic conditions, especially to combinations of high temperature and low humidity; temperatures above $40{ }^{\circ} \mathrm{C}$ or below $13{ }^{\circ} \mathrm{C}$ increase mortality.

Native habitat (EUNIS code): F5 - semi-arid and subtropical habitats.

Habitat occupied in invaded range (EUNIS code): F5 - Maquis, matorral and thermoMediterranean brushes; F6 - Garrigue; F8 - Thermo-Atlantic xerophytic habitats; H5 - Miscellaneous inland habitats with very sparse or no vegetation; I1- Arable land and market gardens; I2 - Cultivated areas of gardens and parks; J100- Glasshouses.

Native range: Origin unclear, probably Egypt. Widespread in tropical and subtropical Africa and Southeastern Europe and Asia Minor.

Introduced range: One of the most commonly intercepted species in Europe, for example on imported ornamentals. Present outdoors in Sicily, southern Italy, Corsica, Spain, southern Portugal, and in Madeira and the Canary Islands but only in glasshouses in northern Italy, Western and Central Europe (Map). Not established in Great Britain.

Pathways: Trade appears to be the most likely pathway for introduction, through eggs and larvae present on imported commodities such as glasshouse crops, both ornamentals and vegetables from infested areas. Flight range of moths can be $1.5 \mathrm{~km}$ during a period of $4 \mathrm{~h}$

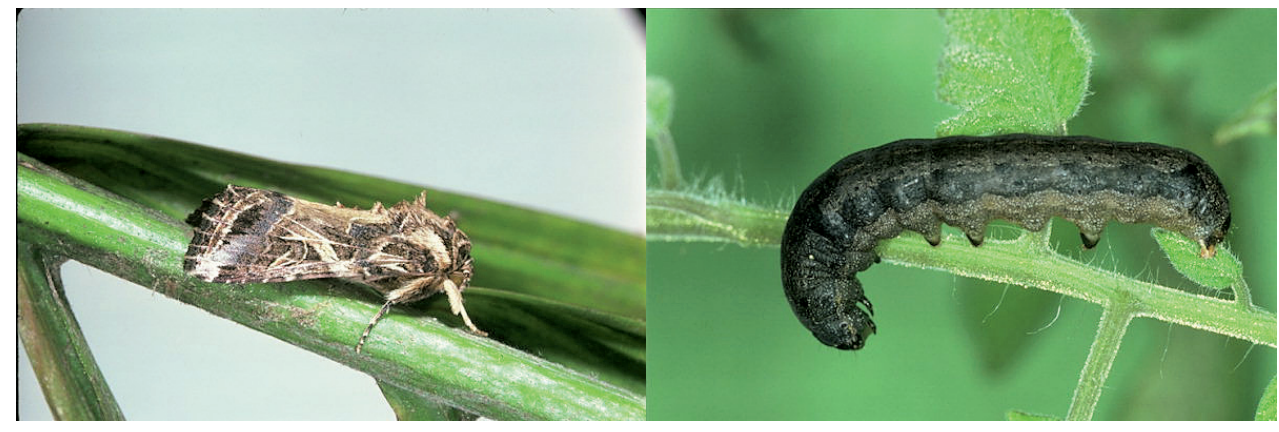

Credit: Paolo Mazzei (left), Jean-Yves Rasplus/ INRA (right) 


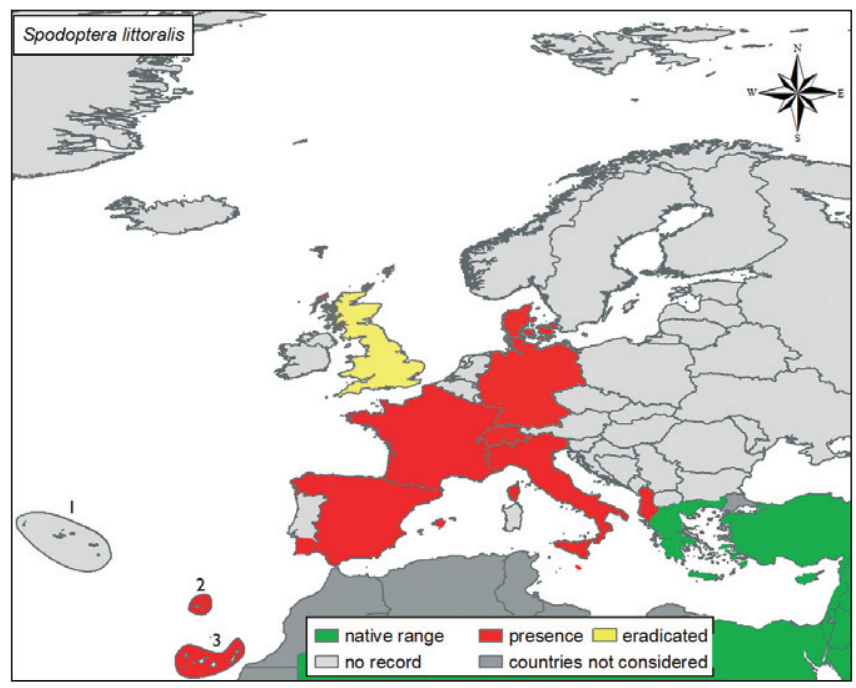

overnight. Adult moths can also be spread through wind, attached to or transported by another organism or through other natural means.

Impact and management: Spodoptera littoralis is one of the most destructive agricultural lepidopteran pests within its subtropical and tropical range, attacking plants from 44 families including grasses, legumes, crucifers and deciduous fruit trees. In North Africa damages vegetables, in Egypt cotton, and in Southern Europe, plant and flower production in glasshouses or vegetables and fodder crops. It is important to seek assurance from suppliers that plants are free from this pest as part of any commercial contract. Avoid importing plant material from infested areas. Carefully inspect new plants on arrival, including any packaging material, to check for eggs and caterpillars and for signs of damage. As the adults are nocturnal, light or pheromone traps should be used for monitoring purposes. Mechanical control: physical destruction of insects and any plant material infested by this pest is recommended. Egg masses can be hand collected. Chemical control: there are many cases of resistance to insecticides. Biological control: includes the use of microbial pesticides, insect growth regulators and slow-release pheromone formulations for mating disruption.

\section{Selected references}

Abdel-Megeed MI (1975) Field observations on the vertical distribution of the cotton leafworm, Spodoptera littoralis on cotton plants. Zeitschrift für Angewandte Entomologie 78: 597-62. Brown ES, Dewhurst CF (1975) The genus Spodoptera (Lepidoptera, Noctuidae) in Africa and the Near East Bulletin of Entomological Research 65: 221-262.

EPPO/OEPP (2003) Fiche informative sur les organismes de quarantaine. Spodoptera littoralis and Spodoptera litura. http://www.eppo.org/QUARANTINE/insects/Spodoptera_ littoralis/F-spodli.pdf. 


\title{
14.75 - Epichoristodes acerbella (Walker, 1864) - African Carnation Tortrix (Lepidoptera, Tortricidae)
}

\author{
Stanislav Gomboc
}

Description and biological cycle: Small moth, 14-24 mm wingspan, female larger than male. Forewing ochreous yellow to brownish yellow, often with a darker band towards the distal edge; hindwings greyish-white (Photo left). Number of generations depends on temperature. In Africa, the moth has several generations yearly, without diapause. In southern Europe, there are 3-4 generations (April - October) outdoors and 4-5 generations in glasshouses. Generations are difficult to distinguish since all stages are present for most of the year. Female lays 200-240 eggs in groups of 80-120 eggs in a period of three days, on the upper side of the leaf. Eggs hatch after about ten days. Lower threshold of their development is about $6^{\circ} \mathrm{C}$, but they are able to withstand lower temperatures in the hibernation period. Larva variable in colour, green, yellowish or grey, with darker dorsal and subdorsal lines (Photo-right). Pupation occurs after about $30 \mathrm{~d}$ and the pupal stage lasts eight $\mathrm{d}$. The development from egg to adult is influenced by temperature: $11^{\circ} \mathrm{C}-170 \mathrm{~d}, 17^{\circ} \mathrm{C}-70 \mathrm{~d}, 20^{\circ} \mathrm{C}-40 \mathrm{~d}$. Host plants mainly include Dianthus and Chrysanthemum but also Pelargonium, Medicago, Lupinus, Lycopersicon, Rosa, Capparis, Pyrus, Malus, Prunus, Rhamnus, and some weeds such as Sonchus, Rumex, Oxalis, Carex, Erigeron, Ornitogalum and others.

Native habitat (EUNIS code): Unknown.

Habitat occupied in invaded range (EUNIS code): Mainly J100-glasshouses ; but also I1- Arable land and market gardens; I2- Cultivated areas of gardens and parks ; FB- Shrub plantations; Shrub plantations for ornamental purposes ; F5- Maquis, arborescent matorral and thermo-Mediterranean brushes.

Native range: South Africa, Eastern Africa (Kenya) and Madagascar.

Introduced range: Firstly reported in Europe in mid-1960s from glasshouses in Scandinavian countries. At present, regional distribution in France, Italian mainland, Sardinia, Sicily,

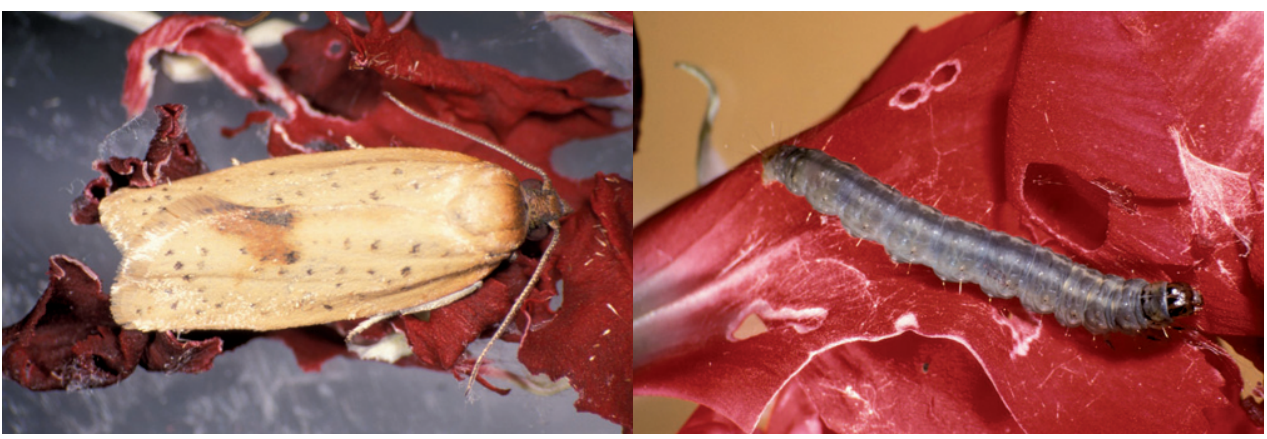

Credit: Stanislas Gomboc 


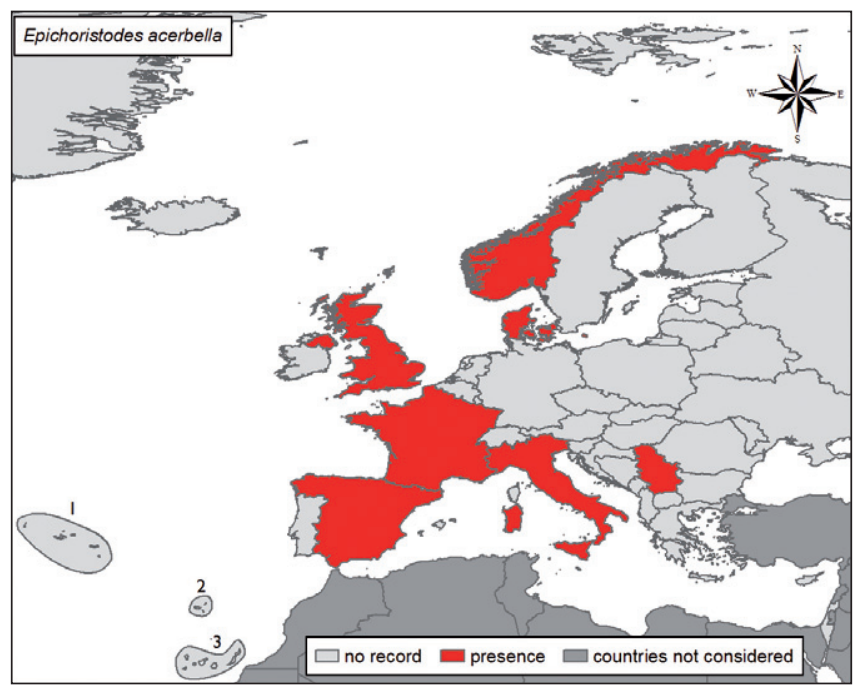

Spanish mainland, south England, Serbia and also in plantations in Germany and Danish mainland (Map). Intercepted many times on cut flower shipments in other European countries, but not yet established there.

Pathways: Passive international transport (airplanes, vehicles) of cut flowers and ornamental plants is the quickest means of spread. Adults fly only on short distances but the moth can disperse in any of its development stage, early stages being hidden on or inside plant tissue.

Impact and management: Important indoor and outdoor pest of cultivated, mainly ornamental plants. In European carnation cultivars, African Carnation tortrix may attack up to $90 \%$ of the crop; an important pest of Chrysanthemum and some field crops. Larvae are polyphagous and feed first on the leaf, under a shelter of silk, later in buds, flowers or stems. Young leaves are perforated and wilt and, more typically, stems are mined; flower buds are also perforated, become desiccated and petals are often woven together by silk. Difficult to control, due to hidden lifestyle. Spraying or fumigation with insecticides is still the best control method. Avoid importing plant material from infested areas or inspection of plants on arrival. The adults are nocturnal, and can be monitored by pheromone traps or by light traps; eggs, larvae and pupae by observation of presence on plants or plant damage. Biological control is still under investigation: possibly by using mating disruption with pheromones or by parasitoids like trichograms (Trichogramma dendrolimi, T. voegelei, T. dendrolimi).

\section{Selected references}

Costa Seglar M, Vives Quadras JM (1976) Epichoristodes acerbella Walk, nuevo tortrícido, plaga de los claveles, en la Península Ibérica. SHILAP Revista de Lepidopterologia 4: 233-234. Zangheri S, Cavalloro R (1971) Sulla presenza in Italia di Epichoristodes acerbella (Walker) (Lepidoptera Tortricidae). Bolletino della Società Entomologica Italiana 103: 186-190. 


\title{
14.76 - Grapholita molesta (Busck, 1916) - Oriental fruit moth (Lepidoptera, Tortricidae)
}

\author{
Zdeněk Laštůvka
}

Description and biological cycle: Wingspan 11-13 mm, body length 6-7 mm; small tortricid moth, forewing dark, greyish black, more or less distinct black transverse lines, oblique strigulae on the costa, black spots along distal margin and distinct light spot in the middle of the distal half of the wing (Photo left); very similar to the native European plum fruit moth (Grapholita funebrana); reliable determination possible only after genitalic dissection; oligophagous on Prunus s.l. spp. (peach, nectarine, apricot, almond, plum, cherry), on apple (Malus), pear (Pyrus), occasionally on quince (Cydonia), medlar (Mespilus), hawthorn (Crataegus), loquat (Eriobotrya japonica), Cotoneaster, Eugenia and Photinia; the species develops 2-4 generations per year following climatic conditions and adults are on wing between May and October; female lies about 200 eggs during its life lasting 10-14 days; eggs are whitish, flattened, oval in shape, $0.7-0.8 \mathrm{~mm}$ long; they are laid usually on the leaf underside, less often on new shoots or on fruits; larva of the first generation bores tunnels in terminal parts of young shoots; of following generations it lives usually in fruits (Photo right-frass exiting from infested fruit); mature larvae of the last generation overwinter in cocoons in crevices under bark or in the soil litter and they pupate in early spring.

Native habitat (EUNIS code): G- Woodland and forest habitats and other wooded land.

Habitat occupied in invaded range (EUNIS code): I1 - Arable land and market gardens; I2 - Cultivated areas of gardens and parks (fruit orchards, lines of fruit trees, fruit gardens, ornamental cultures).

Native range: East Asia (China, Korean Peninsula, Japan).

Introduced range: Introduced over the world mostly during the first three decades of the 20th century. Described as new species by Busck from the introduced range (USA, Virginia) in 1916. In Europe recorded for the first time in 1920 in Italy and France. Today present in Western, Central, Southern and Southeastern Europe (Map); not known from Poland, but very probably present, occasionally imported with fruit into more northern countries such as

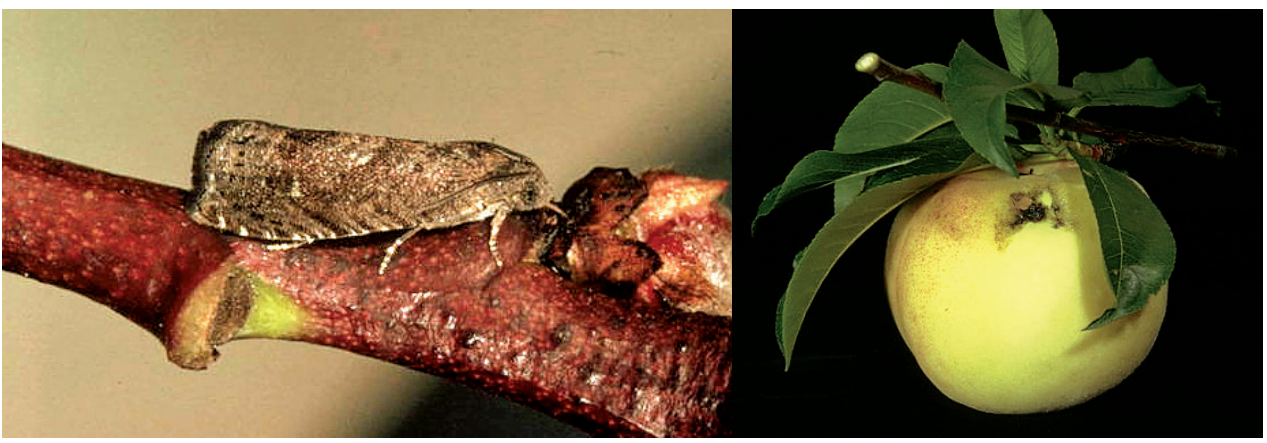




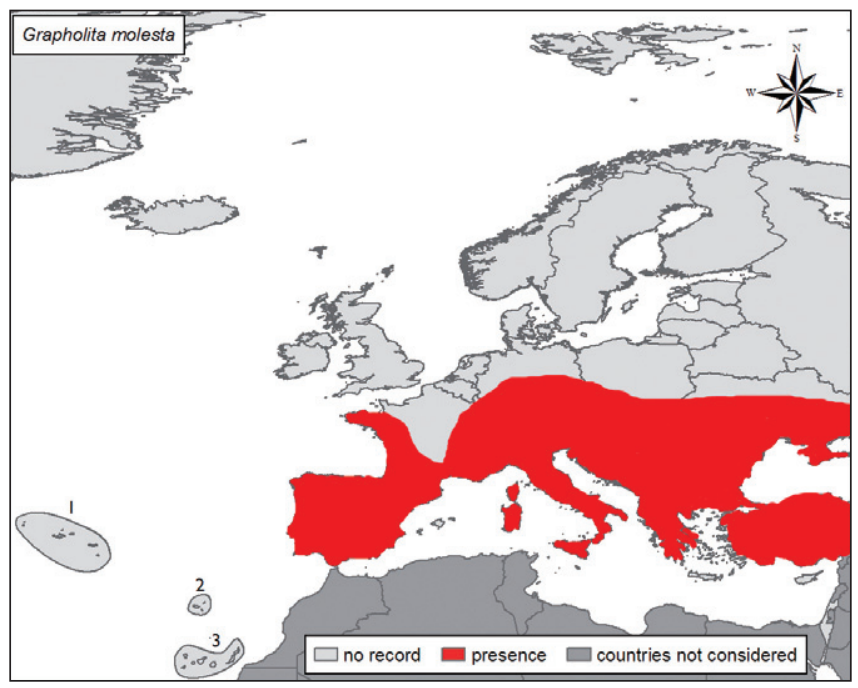

Great Britain, Belgium, Denmark, Sweden, Lithuania, Latvia, Byelorussia, but probably not naturalized there. Also recoreded from other temperate and partly subtropical regions of the world: Southwestern Asia (Armenia, Azerbaijan, Georgia, southern Kazakhstan - possibly native, Uzbekistan - possibly native), Africa (Morocco, Southern Africa), North America (USA, southern Canada - Ontario, North Mexico), southern parts of South America (Argentina, southern Brazil, Chile, Uruguay), eastern half of Australia, and New Zealand.

Pathways: Mostly passive transport of cocoons on dormant fruit-tree nursery stock and in containers with fruits, or directly with infested fruits. Dispersal at a local scale is realized by active flight of adults.

Impact and management: The oriental fruit moth is one of the most important pests of stone and other fruit trees (especially on peaches and nectarines) causing considerable economic damage. Ecological impact is not known, but an influence on native parasitoid abundance and their trophic chains is possible. Monitoring is possible using pheromone traps. A number of insecticides were used for chemical control during the last decades (various organophosphates, pyrethroids, carbamates, neonicotinoids, insect growth regulators). Biological control possibilities include various kinds of bioagents tested or applied locally as granuloviruses, $\mathrm{Ba}$ cillus thuringiensis, entomoparasitic nematodes (Steinernema and Heterorhabditis spp.); also hymenopteran (several Ichneumonidae, Pteromalidae, Trichogramma spp., etc.) and dipteran (Tachinidae) parasitoids. Mating disruption by synthetic sexual pheromones was largely used during recent years.

\section{Selected references}

Kyparissoudas DS (1989) Control of Cydia molesta (Busck) by mating disruption using Isomate-M pheromone dispensers in northern Greece. Entomologia Hellenica 7: 3-6.

Paoli G (1922) Un lepidottero nuovo per la fauna italiana (Laspeyresia molesta Busck). Bollettino della Società Entomologica Italiana 54: 122-126. 


\subsection{7 - Argyresthia thuiella (Packard, 1871) - Arborvitae leaf miner (Lepidoptera, Yponomeutidae)}

Ferenc Lakatos

Description and biological cycle: Tiny moth, adults with wingspan of 4-6mm. Forewings silvery, tip brownish. Larvae rosy with black head. Females lay eggs after mating on the foliage in June (Photo left - detail of an egg). After hatching, larvae enter the leaves, where they feed, overwinter and also pupate. Larva starts feeding at the tip of branch towards trunk. Branch tip becomes yellowish (Photo right), later brown. This species has one generation both in Europe and in the native area (Eastern North-America). Adults fly around the host trees, different Thuja species, during the daytime.

Native habitat (EUNIS code): G- Woodland and forest habitats and other wooded land.

Habitat occupied in invaded range (EUNIS code): G5- Lines of trees; I2- Cultivated areas of gardens and parks.

Native range: North America.

Introduced range: Supposedly introduced three times independently (1971: the Netherlands; 1975: Germany; 1976: Austria). Argyresthia thuiella expanded its distribution in the

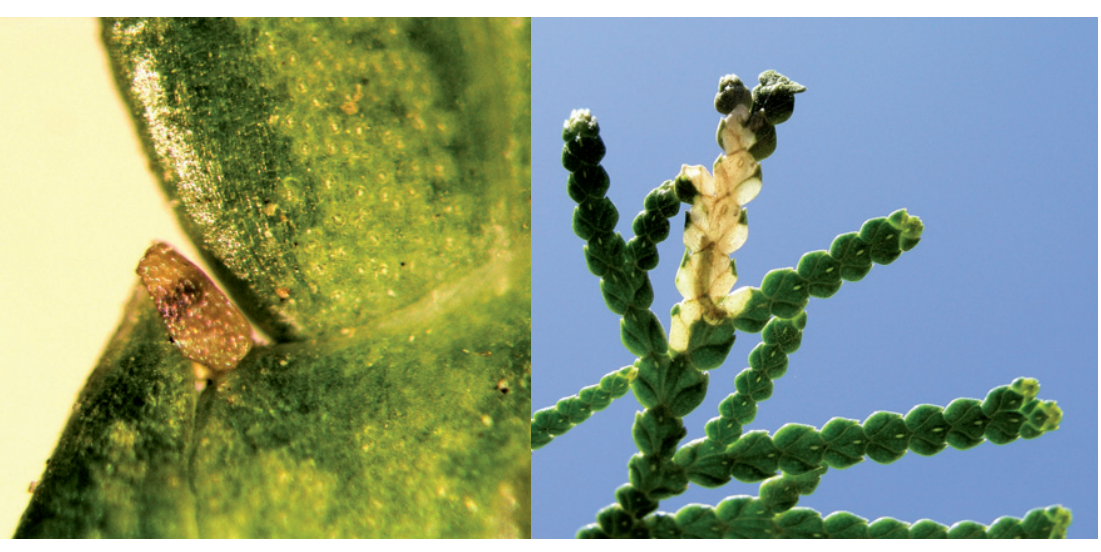

Credit: Hana Šefrová 


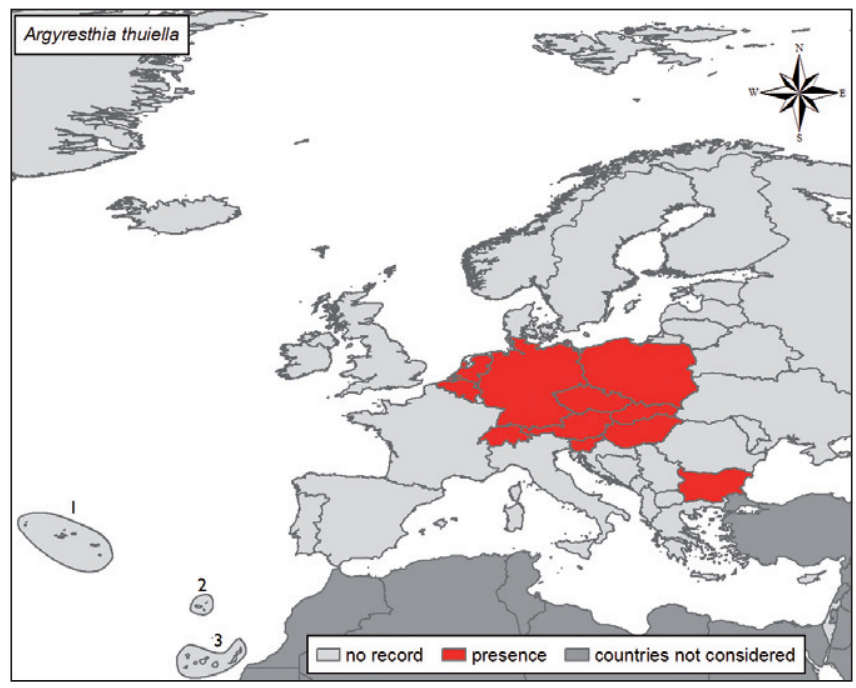

last decades to most of continental Europe, except Scandinavia and Iberian Peninsula (Map). However damage caused by this species has decreased with this expansion.

Pathways: Probably trade of ornamental Cupressaceae.

Impact and management: Damage was important only during his expansion phase after establishment. At present, frequent in urban areas such as parks, gardens and urban forests. Several parasitoids were reared from different developmental stages already at the start of this moth's presence in Europe (e.g. Pteromalidae, Eulopidae and Braconidae). After establishment, chemical suppressants were widely used, but as damage decreased so did the need for control. Attractants are known and available for the members of the genus Argyresthia, but not so far used for monitoring or mass trapping.

\section{Selected references}

Frankenhuyzen Av (1974) Argyresthia thuiella (Pack.) (Lep., Argyresthiidae). Entomologische Berichten 34: 106-111.

Škerlavaj V, Munda A (1999) Argyresthia thuiella Packard - a new pest of Thuja in Slovenia. Zbornik predavanj in referatov 4. slovenskega posvetovanja o varstvu rastlin v Portorožu od 3. do 4. Marca 1999, Ljubljana: Društvo za varstvo rastlin Slovenije, p. 451. 


\title{
14.78 - Frankliniella occidentalis (Pergande, 1895) - Western flower thrips (Thripidae, Thysanoptera)
}

\author{
Alain Roques
}

Description and biological cycle: Tiny, slender thrips with narrow fringed wings (Photo). Males, $1.2-1.3 \mathrm{~mm}$ long, are pale yellow, females, 1.6-1.7 $\mathrm{mm}$ long, are yellow to brown; larvae are yellowish-white. Adults and larvae suck plant fluids from flowers and leaves of at least 244 plant species from 62 families. Western flower thrips reproduces in glasshouses with $12-15$ generations/year. Overall life cycle lasts from $44 \mathrm{~d}$ at $15^{\circ} \mathrm{C}$ to $15 \mathrm{~d}$ at $30^{\circ} \mathrm{C}$. A female can lay 20-40 eggs. Unmated females produce males. Different developmental stages are typically found in different parts of plants: eggs in leaves, flower tissue and fruits; nymphs on leaves, in buds and flowers; pupae in soil or in hiding places on host plants such as the bases of leaves; adults on leaves, in buds and flowers.

Native habitat (EUNIS code): I - Regularly or recently cultivated agricultural, horticultural and domestic habitats.

Habitat occupied in invaded range (EUNIS code): I1 - Arable land and market gardens; J100 - glasshouses.

Native range: North America.

Introduced range: Reported from all continents; first record in Europe in 1983 in the Netherlands; continuous and rapid spread since the 1980s; present in glasshouses in North and central Europe, but already outdoors in Southern Europe (Map).

Pathways: Intercontinental dispersal of eggs, larvae and adults is taking place with the trade of ornamental plants (e.g., cut flowers, potted plants). Adults can be easily carried by winds, but also by clothes, equipment and containers not properly cleaned.

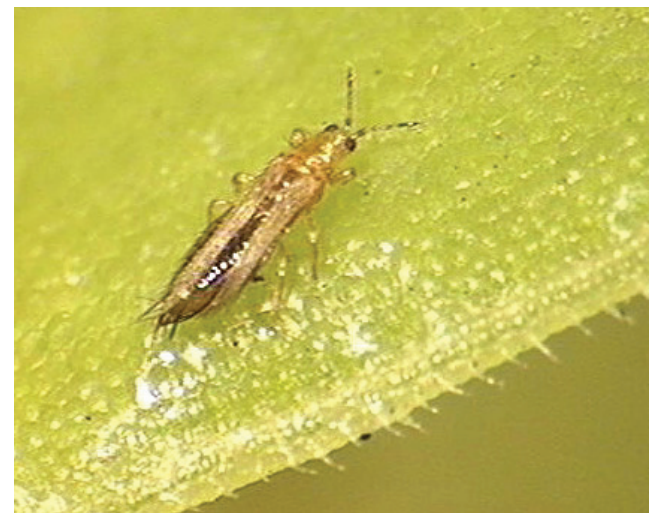

Credit: Philppe Reynaud 


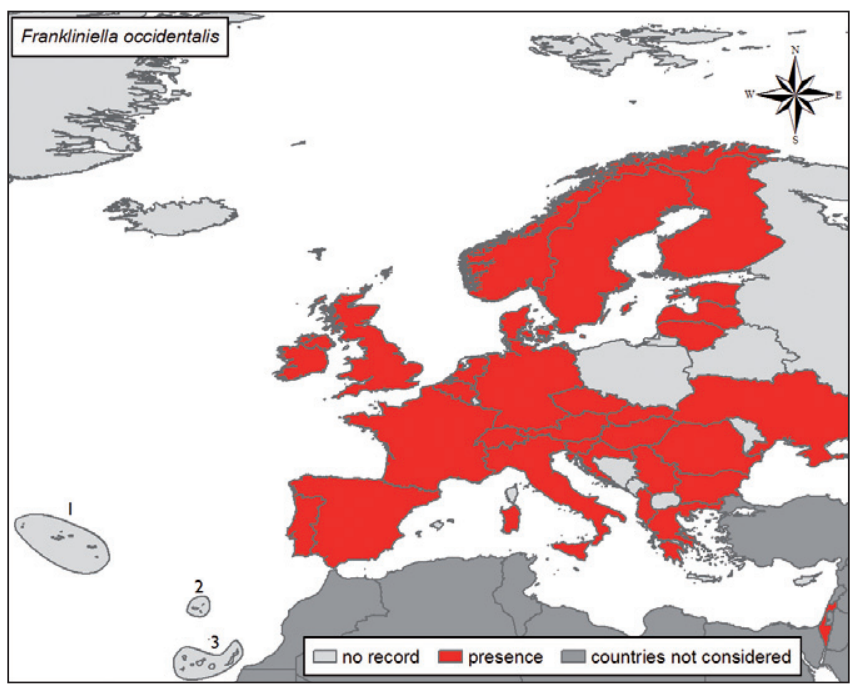

Impact and management: An outdoor pest as well as a glasshouse pest. Flowers and foliage of a great number of economically important crops are affected, in glasshouses as well as outdoors. On ornamental flower crops, feeding induces discolouration, indentation, distortion and silvering of the upper leaf surface as well as scarring and discolouration of petals and deformation of flower heads, largely reducing their economic value. In orchids, eggs laid in petal tissues cause a 'pimpling' effect on flowers. This thrips also kills or weakens terminal buds and blossoms in fruit trees (e.g., apricot, peach) and roses, and on most fruiting vegetables, especially cucumbers. In addition, nymphs are vectors of tobacco streak ilarvirus (TSV) and tomato spotted wilt virus (TSWV), which is inducing severe diseases in ornamental and vegetable crops in Europe. Blue sticky traps can be used to detect initial infestation and to monitor adult population levels. Chemical control is difficult because this thrips is resistant to most pesticides and feeds deep within the flower or on developing leaves. Biological predatory mites (e.g., Neoseiulus cucumeris, Amblyseius spp. and Hypoaspis spp.) and minute pirate bugs (e.g., Orius laevigatus, O. insidiosus) provide effective biological control, in glasshouses.

\section{Selected references}

Del Bene G, Gargani E (1989) [A contribution to the knowledge of Frankliniella occidentalis] (in Italian). Redia 72: 403-420.

EPPO/CABI (1997). Frankliniella occidentalis. Quarantine Pests for Europe. Wallingford, United Kingdom: CAB International, 267-272.

Mantel WP (1989) Bibliography of the western flower thrips, Frankliniella occidentalis. Bulletin SROP 12: 29-66. 


\title{
14.79 - Pseudodendrothrips mori (Niwa, 1908) - Mulberry thrips (Thripidae, Thysanoptera)
}

\author{
Philippe Reynaud
}

Description and biological cycle: Oligophagous thrips with small to minute and very pale bodies. Males 0.7-0.9 mm long; females 0.9-1.1 mm long. Mulberry thrips is a member of the Dendrothripinae subfamily distinguished from other Thripidae by the presence of a remarkably elongate metasternal endofurca* providing active jumping capacities (Photo left). Pseudodendrothrips mori commonly breeds on Morus alba and M. bombycis or on Ficus throughout the world and is a widespread although minor pest of Morus (Photo right-damage on leaf). Mulberry thrips reproduces outdoors with 6-10 generations per year in its native area. In mid-March, overwintering adults emerge to damage the leaves. The complete life cycle lasts 26-34 days in spring and autumn, and $16-23$ days in summer, depending on conditions. Increased temperature $\left(26-32^{\circ} \mathrm{C}\right)$ directly influence the breeding activity of the thrips and thereby increases the population levels. July and August are peak months of occurrence; the final stage of appearance is in late autumn. Adults overwinter after October, thus completing the annual life cycle. Seasonal population fluctuations and the degree of damage caused to the host plant are influenced by various environmental factors, including climate, host plant variety, topography, soil type and management regimes.

Native habitat (EUNIS code): Unknown.

Habitat occupied in invaded range (EUNIS code): I2- Cultivated areas of gardens and parks.

Native range: Probably originated from China or Japan.

Introduced range: Recorded from several parts of the world, including USA, India, Iran and Australia. First recorded in 1974 in Italy; at present known only in few more countries (Spain and France). The rate of spread seems to be low.

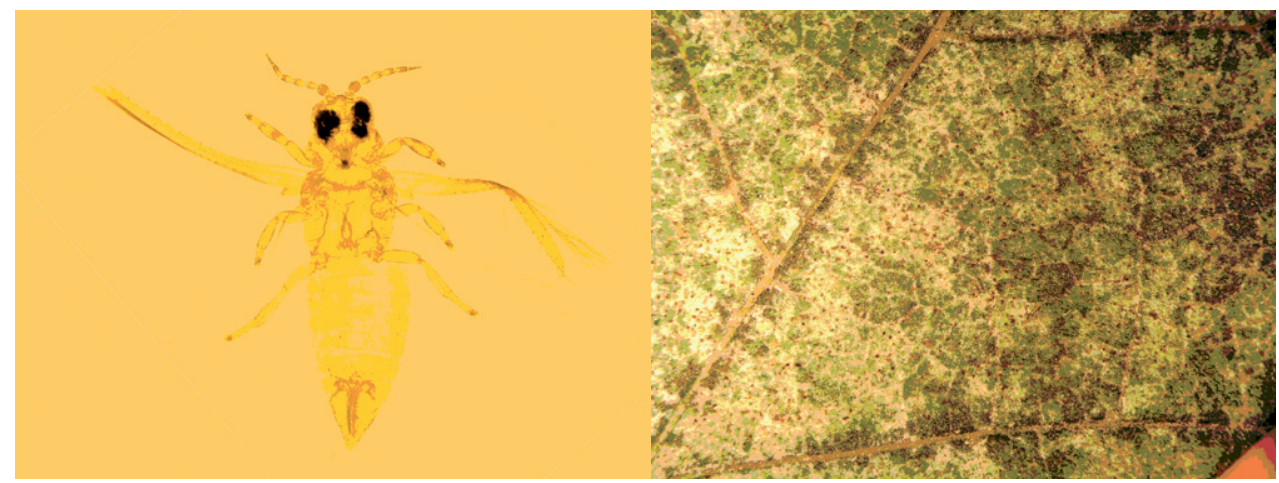

Credit: Georgi Trenchev and Katia Trencheva 


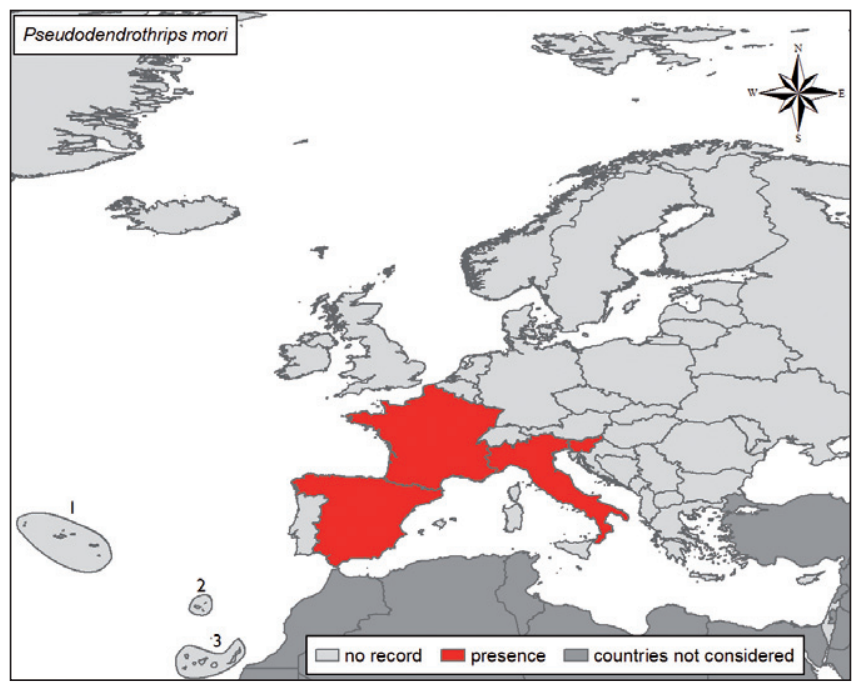

Pathways: Probably trade of ornamental plants.

Impact and management: Mulberry leaves are the exclusive food of the silkworm, Bombyx mori. Mulberry thrips have caused serious damage to sericulture in the southern states of India and China while damage to this industry is also reported in Sri Lanka and Vietnam. Feeding silkworms with mulberry leaves that have been damaged by mulberry thrips causes slower development, increases larval mortality and reduces cocoon yield. In other countries such as Japan, Iran and some countries in Europe and America, production of silk is very limited. Here mulberry is mainly an ornamental tree which is grown by roads because of its low need for water and nutrients, and $P$. mori can damage plants growing in these situations. Chemical control is the main method used to control P. mori in silk production areas. However, it is assumed that in countries where Morus are used as ornamental plants, damage by the pest could be mitigated using non-chemical methods which are economically or ecologically tolerable.

\section{Selected references}

Cappellozza L, Miotto F (1975) Pseudodendrothrips mori (Niwa) (Thysanoptera Terebrantia) specie nuova per la fauna Italiana. Redia 56: 387-389.

Trenchev G, Trencheva K (2007)Pseudodendrothrips mori Niwa (Thysanoptera, Thripidae), a species new to the Bulgarian fauna. Zachita na Rastenija 18: 68-71.

Vierbergen G, Cean M, Szeller IH, Jenser G, Masten T, Simala M (2006) Spread of two thrips pests in Europe: Echinothrips americanus and Microcephalothrips abdominalis (Thysanoptera: Thripidae). Acta Phytopathologica et Entomologica Hungarica 41: 287-296. 


\subsection{0 - Thrips palmi (Karny, 1925) - Melon thrips (Thripidae, Thysanoptera)}

\section{Philippe Reynaud}

Description and biological cycle: Completely yellow thrips (Photo). Males 0.9-1.0 mm long, females $1.1-1.3 \mathrm{~mm}$ long. Identification is hampered by small size and a great similarity with other yellow species of Thrips. Melon thrips is a polyphagous feeder and an outdoor pest of aubergine (Solanum melongena), sweet pepper (Capsicum annuum), cotton (Gossypium spp.) cowpea (Vigna unguiculata), cucumber (Cucumis sativus), Cucurbita spp., melon (Cucumis melo), pea (Pisum sativum), Phaseolus vulgaris, potato (Solanum tuberosum), sesame (Sesamum indicum), soyabean (Glycine max), sunflower (Helianthus annus), tobacco (Nicotiana tabacum) and watermelon (Citrullus lanatus). In glasshouses, economically important hosts are aubergine, Capsicum annuum, Chrysanthemum, cucumber, Cyclamen, Ficus and Orchidaceae. To develop from egg to adult, Thrips palmi requires 194 day-degrees above a thermal threshold of $10.1^{\circ} \mathrm{C}$, and takes between 10 days (at $30^{\circ} \mathrm{C}$ ) to 40 days $\left(\right.$ at $15^{\circ} \mathrm{C}$ ) to complete its life-cycle which is lengthened to 80 days when the insects are at $13^{\circ} \mathrm{C}$. Melon thrips are able to multiply during any season that crops are cultivated, but are favoured by warm weather.

Native habitat (EUNIS code): I1- Arable land and market gardens.

Habitat occupied in invaded range (EUNIS code): I- Regularly or recently cultivated agricultural, horticultural and domestic habitats; J- Constructed, industrial and other artificial habitats.

Native range: First described in 1925 in Sumatra but remained little known, often overlooked and the subject of taxonomic confusion until 1980.

Introduced range: From the late 1970s, Melon thrips has spread across the Far East and in subsequent decades within South East Asia, and to Australia, the Pacific, Florida, the Car-

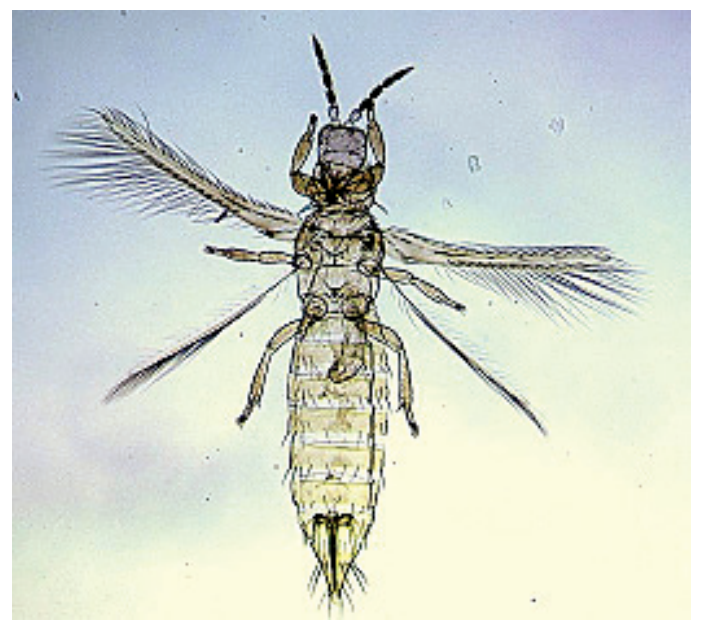




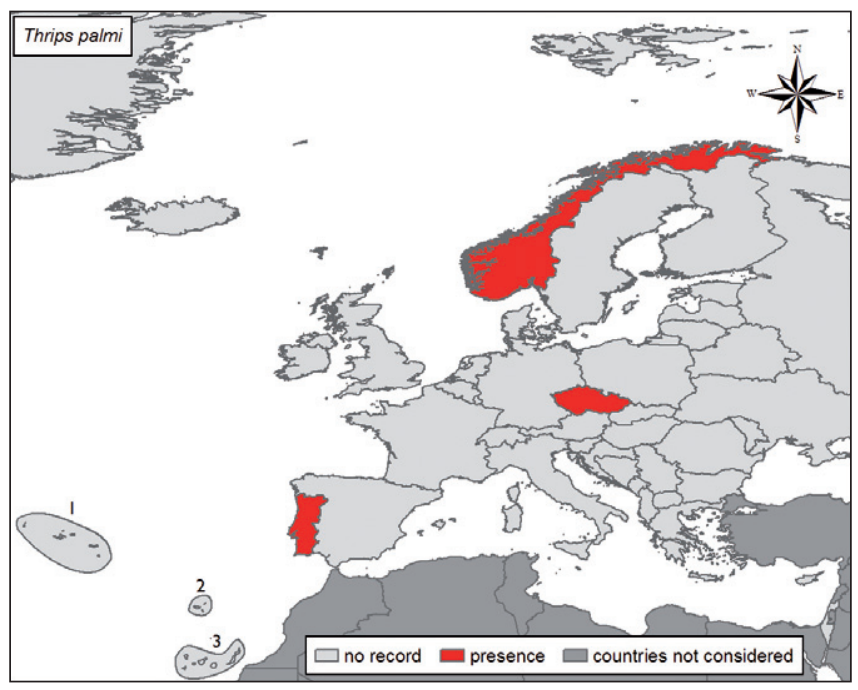

ibbean, South America and West Africa. In Europe, numerous interceptions have been reported on cut flowers and fruit vegetables from Thailand, Mauritius, India, etc. Several limited outbreaks were found in glasshouses in Netherlands and in Great Britain since 1988, but all these outbreaks were eradicated. May-be still present in glasshouses of Norway and the Czech Republic. T. palmi is considered to be absent outdoors in Europe although it was detected in flowers of kiwi fruit (Actinidia deliciosa) plantations in Portugal in 2004; in later surveys the pest was no longer found.

Pathways: Trade of plant material (ornamentals, vegetables, fruits).

Impact and management: Melon thrips cause severe injury to infested plants. Leaves become yellow, white or brown, and then crinkle and die. Heavily infested fields sometimes acquire a bronze color. Terminal growth damage occurs via discolouration, stunting, or deformation. Fruits may also be damaged with scars, deformities and abortion. T. palmi has been shown to transmit plant viruses including Groundnut bud necrosis virus (GBNV), Melon yellow spot virus (MYSV), Watermelon silver mottle virus (WSMoV), Tomato spotted wilt virus (TSWV) and Capsicum chlorosis virus $(\mathrm{CaCV})$. However, this list is questionable due to lack of consistent studies. Experience of controlling or eradicating T. palmi has been gained in a large number of countries as this pest has spread around the world. However, melon thrips requires frequent spraying of insecticides, so resistance to many chemicals has developed. It is now considered that control with insecticides alone is not adequate. Integrated pest management is necessary, including cultural practices and biological control.

\section{Selected references}

Anonymous (2004). First report of Thrips palmi in Portugal. EPPO Reporting Service 144: 2. Cannon RJC, Matthews L, Collins DW, Agallou E, Bartlett PW, Walters KFA, MacLeod A, Slawson DD, Gaunt A (2007) Eradication of an invasive alien pest, Thrips palmi. Crop

Protection 26: 1303-1314. 